Visualidade e sexualidade em Las Meninas, de Picasso, e na obra madura do artista (1957-1972) 

Universidade de São Paulo

Escola de Comunicações e Artes

Programa de Pós-Graduação em Artes Visuais

\section{Visualidade e sexualidade em Las Meninas, de Picasso, e na obra madura do artista (1957-1972)}

Janaina Nagata Otoch

Dissertação apresentada ao Programa de Pós-Graduação em Artes Visuais da Escola de Comunicações e Artes da Universidade de São Paulo, como requisito parcial para a obtenção do título de Mestre em Artes Visuais.

Orientadora

Profa. Dra. Sônia Salsztein Goldberg 
Autorizo a reprodução e divulgação total ou parcial deste trabalho, por qualquer meio convencional ou eletrônico, para fins de estudo e pesquisa, desde que citada a fonte.

Catalogação na Publicação

Serviço de Biblioteca e Documentação

Escola de Comunicações e Artes da Universidade de São Paulo

Dados inseridos pelo(a) autor(a)

Otoch, Janaína Nagata

Visualidade e sexualidade em Las Meninas, de Picasso, e na obra madura do artista: (1957-1972) / Janaína Nagata Otoch ; orientadora, Sônia Salzstein Goldberg. -São Paulo, 2019.

264 p.: il.

Dissertação (Mestrado) - Programa de Pós-Graduação em Artes Visuais Escola de Comunicações e Artes / Universidade de São Paulo.

Bibliografia

Versão original

1. Pablo Picasso 2. Las Meninas 3. visualidade 4. sexualidade

5. crítica feminista I. Salzstein Goldberg, Sônia II. Título.

CCD 21. ed. -700

Elaborado por Sarah Lorenzon Ferreira - CRB-8/6888 


\section{Visualidade e sexualidade em Las Meninas, de Picasso, e na obra madura do artista (1957-1972)}

Janaina Nagata Otoch

Dissertação apresentada ao Programa

de Pós-Graduação em Artes Visuais

da Escola de Comunicações e Artes da

Universidade de São Paulo, como requisito

parcial para a obtenção do título de

Mestre em Artes Visuais.

Orientadora

Profa. Dra. Sônia Salsztein Goldberg, 2019

Data da aprovação

Banca Examinadora 

A pesquisa de mestrado foi realizada com apoio da Fundação de Amparo à Pesquisa do Estado de São Paulo - FAPESP.

No. do processo $2017 / 20620-4$. 



\section{Agradecimentos}

Meus profundos agradecimentos à Sônia Salzstein, cuja dedicada e rigorosa orientação foi fundamental para o desenvolvimento da pesquisa e da dissertação. Pela convivência, pelo apoio e interlocução nos últimos anos.

À Liliane Benetti e Samuel Titan Jr., pelas preciosas críticas, sugestões e comentários durante a banca de qualificação, importantes para reformular o trabalho, ampliar as referências e aprimorar a estrutura e os objetivos da dissertação.

À Fundação de Amparo à Pesquisa do Estado de São Paulo, pelo auxílio imprescindível para a realização da pesquisa.

Agradeço também aos professores, alunos, funcionários e colegas do Departamento de Artes Plásticas da Universidade de São Paulo, e a todos que lutam pela existência da universidade pública e de qualidade no Brasil.

Aos funcionários de museus e arquivos visitados durante a pesquisa. Um agradecimento especial à Margarida Cortadella, Ariadna Olivé e a toda equipe do Museu Picasso Barcelona, pela gentileza e o auxílio zeloso durante o breve período em que estive pesquisando nas dependências da instituição.

À família, Akemi, Pinhata, Luara, Felippe e Laís. Às amigas e amigos que sempre estiveram presentes, pelo apoio incondicional. À Adriana Moreno e Bruna Batalhão, pelo carinho e a imprescindível companhia nas manhãs, tardes e noites de biblioteca. Aos amigos de infância e à Petra Ferronato por me receber em Barão Geraldo sempre que precisei consultar os acervos da biblioteca da Unicamp. Ao Rodolfo Faria Silva, pelo apoio e pela pronta disposição em me emprestar os livros necessários para a pesquisa. À Marina Zilberzstejn, pela amizade e também pela cuidadosa diagramação do trabalho. Ao Luiz Carlos Oliveira Jr. , pela revisão do texto, pelo companheirismo, e, é claro, pelas prazerosas e, por vezes, polêmicas discussões sobre arte e cultura. À Marina D’Aiuto, que mesmo a milhas de distância estará sempre comigo. 


\section{Resumo}

Esta dissertação propõe discutir as relações entre visão, visualidade e sexualidade na obra de Pablo Picasso, priorizando dois momentos significativos em sua trajetória. De início, parte do exame da série de pinturas Las Meninas (1957) com o intuito de interrogar o papel que visão e olhar, em sentido abrangente, desempenham neste conjunto de trabalhos, inspirados pela obra homônima de Diego Velázquez. Depois de definir e analisar o regime de visualidade nessa série, a dissertação põe em pauta a existência de uma dimensão escopofílica que permeia os trabalhos, verificando seus desdobramentos em uma parcela da obra madura de Picasso, frequentemente qualificada sob o signo do voyeurismo pela fortuna crítica, inclusive em sua vertente feminista. De modo a acrescentar à discussão, a dissertação promove uma abordagem comparativa com Étant Donnés (1946-66), de Marcel Duchamp, buscando atentar para as ressonâncias (ainda que indiretas) e as diferenças entre a produção de Picasso e seus contemporâneos. Dentre os trabalhos examinados nesta abordagem comparada estão um grupo de desenhos e gravuras realizados entre 1968 e 1972 , pouco antes da morte do artista, imagens de desinibida feição pornográfica e repletas de alusões ao voyeurismo, nas quais elementos prosaicos e mesmo vulgares são embaralhados a uma vasta gama de material recolhido do repertório da história da arte. Trata-se de compreender a produção de Picasso e a complexa relação que estabelece com tradição figurativa ocidental, sem perder de vista seu legado aberto à cultura contemporânea.

Palavras-chave: Picasso; Las Meninas; visualidade; sexualidade; voyeurismo; crítica feminista. 


\section{Abstract}

This dissertation aims to discuss the relationships between vision, visuality, and sexuality in Pablo Picasso's oeuvre, focusing two significant moments in his artistic trajectory. Initially I will examine Picasso's Las Meninas (I957), which consists of a series of paintings based on the precedent work by Diego Velázquez. My goal is to explore the ways this set of images adresses vision, and the gaze in the broadest sense. After defining and analysing the scopic regime within the series, I inquire the existence of a scopofilic drive pervading the paintings. Therefore I verify the unfolding of this visual impulse in Picasso's late work, often regarded through the lens of voyeurism by many critics, including feminist scholars. In order to enhance the discussion, a comparative analysis will be traced between these works and Marcel Duchamp's Étant Donnés (1946-66), either to situate them according to its (yet indirect) connections or to face them against their substantial differences. A set of drawings and etchings dating from the last years of Picasso's life wil be included in this comparative approach. These pictures compose a body of works marked by uninhibited pornopraphic features, filled with allusions to voyeurism, to prosaic material or to vulgar imagery which are often mixed with references from various art historical "sources". With such an approach, I seek to consider Picasso's work in regard to its compelling attitude towards the whole classical figurative tradition, without losing sight of its still open legacy to contemporary culture.

Key-words: Picasso; Las Meninas; visuality; sexuality; voyeurism; feminist critique. 


\section{Sumário}

12 INTRODUÇÃO

25 CAPÍTULO I - LAS MENINAS, 1957

A série: Parte I

25 A infanta: gestos, poses e olhar

32 E quanto a Velasquez?

51 Uma silhueta inesperada

49 Sequências e cortes

51 Picasso/TV?

58 Uma atmosfera de suspense, um enigma sem resposta

67 A testemunha ocular

Interlúdio

77 O olhar pela Janela

A série: Parte II

91 As pinturas em grande formato

99 Uma questão de pespectiva

A série, entre outros: Parte III

123 Les Demoiselles/Las Meninas

138 Do ponto de vista feminista

1450 flagrante delito

\section{CAPÍTULO II - O VOYEURISMO EM PERSPECTIVA}

155 E Duchamp? Outra perspectiva em xeque

197 Picasso em suas últimas décadas de vida

222 Ponto de fuga, ponto final

\section{CONSIDERAÇÕES FINAIS}

238 REFERÊNCIAS BIBLIOGRÁFICAS

251 CRÉDITOS DAS IMAGENS 
L'illusion ne saurait aller plus loin.

C'est la nature même prise en flagrant délit de réalisme

THÉOPHILE GAUTIER, SOBRE LAS MENINAS DE VELÁZQUEZ.

Eu tenho impressão de que Delacroix, Giotto, Tintoretto, El Greco e o resto, como também os pintores modernos, os bons e os ruins, os abstratos e os não abstratos, estão todos atrás de mim e me observam enquanto eu trabalho.

PICASSO PARA HÉLÈNE PARMELIN, EM 1963. 


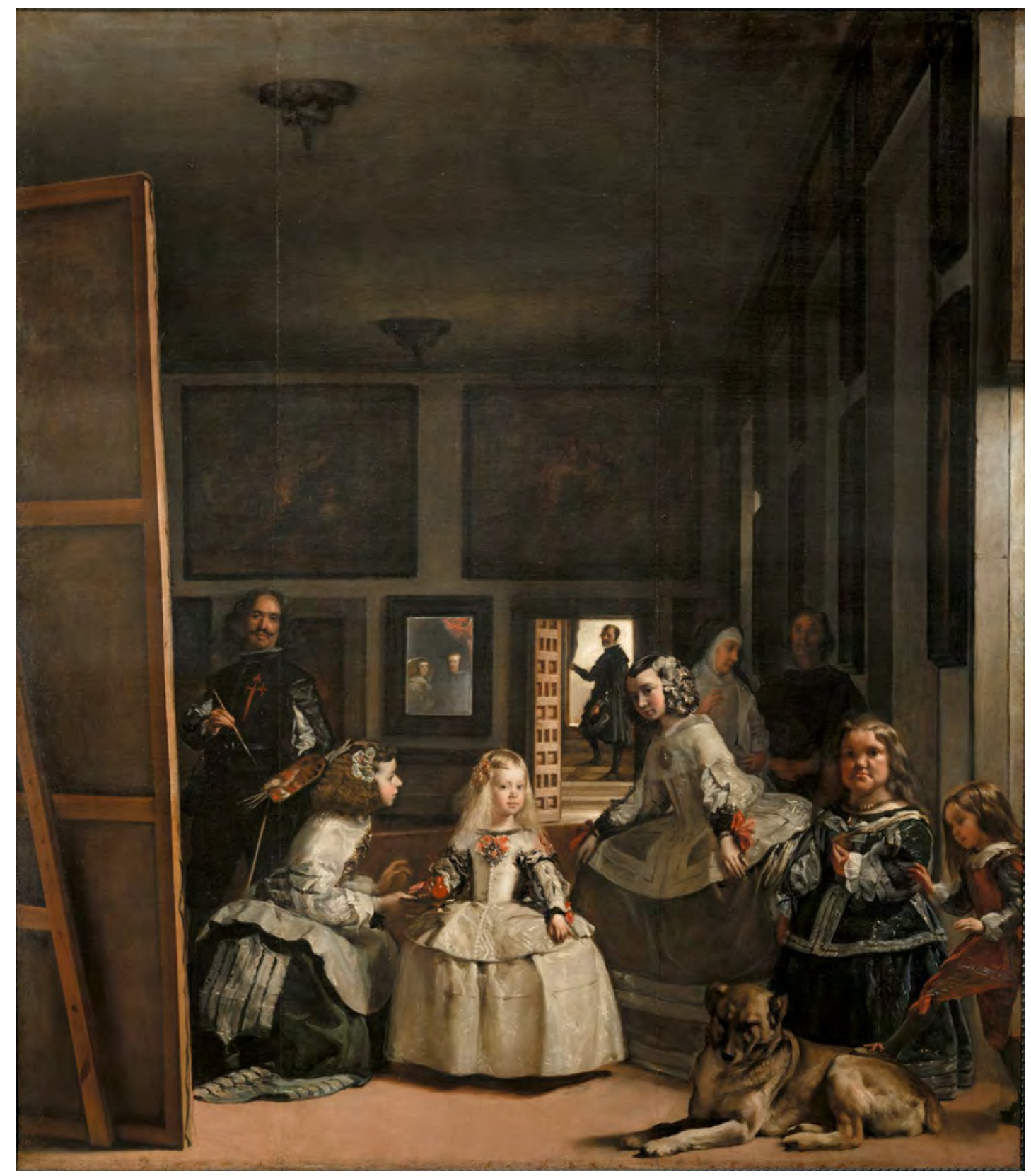

1 Diego Velázquez. Las Meninas, 1656. Óleo sobre tela. 3,18 m x 2,76 m.

Museu do Prado, Madri 


\title{
Introdução
}

\author{
"Que quadro! Que realismo! Que proeza maravilhosa", exclamou Picasso certa vez ao \\ evocar Las Meninas de Velázquez (fig. I) em uma conversa com Kahnweiler ${ }^{1}$. Em outra \\ ocasião, quase vinte anos mais tarde, o artista voltou a referir-se à obra de Velázquez, e, \\ desta vez, conforme relata Roland Penrose, seu comentário foi mais detalhado:
}

\begin{abstract}
Olhe e tente encontrar onde cada um dos personagens está realmente situado. Velázquez pode ser visto na pintura enquanto que, na realidade, ele não deveria estar lá. Ele vira as costas à Infanta, que, à primeira vista, parece ser sua modelo. Ele confronta uma tela grande na qual parece trabalhar e da qual vemos somente o verso, de modo que não temos ideia do que ele está pintando. A única solução é que ele está pintando o rei e a rainha, de quem só vemos o reflexo no espelho ao fundo da sala. ${ }^{2}$
\end{abstract}

1 No original: "Quel tableau! Quel réalisme... Quelle merveilleuse reussite!". Tradução livre pela autora desta dissertação. Vide: PENROSE, Roland: Picasso, Flammarion, Paris, 1982, p 495.

2 Idem. Tradução livre pela autora da dissertação, do francês: "Regard [...] et tache de découvrir où chachun de ces personnages est réellement situe. Velázquez est dans le tableau alors qu'il ne devrait pas y être; it tourne le dos à l'infante qu'à première vue on penserait être son modele. Il fait face à une grande toile sur laquelle il parait travaille; mais on ne voit que le dos du tableau, et nous n'avons pas aucun idée de ce qu'il peint. La seule solution, c'est qu'il est en train de peindre le roi e la reine, dont on ne voit que le reflet dans le miroir tout au fond de la pièce". 
A conversa, segundo o biógrafo e amigo de Picasso, teve lugar em 1958. Onde, afinal, se situam o pintor, o observador, o casal monárquico? Talvez essas questões tenham sido repetidamente formuladas pouco tempo antes, durante os cinco meses finais de 1957, quando Picasso se encerrou no terceiro andar de La Californie, sua residência em Cannes, para dedicar-se exclusivamente à produção de sua própria versão de Las Meninas de Velázquez. Salvo raras visitas recebidas nos dois últimos meses de trabalho, o artista manteve-se em isolamento, munido somente de uma fotografia em branco e preto da pintura do Prado e da companhia de pombos que criava em um palomar. Nessa empreitada, realizou uma série composta de nada menos que cinquenta e oito variações, das quais quarenta e cinco remetiam diretamente à obra de seu conterrâneo.

Pouco menos de uma década depois, o fascínio pela obra de Velázquez tomou novos contornos. Reavivou-se a curiosidade pela posição de cada uma das personagens em relação à complexa trama de olhares que estrutura sua composição; desta vez, não pelas mãos de um artista, mas através da acurada análise filosófica empreendida por Michel Foucault no primeiro capítulo de seu decisivo As Palavras e as Coisas ${ }^{3}$.

Tão logo foi publicada, a análise de Foucault se tornou seminal para o estudo da obra de Velázquez. Grande parte dos estudos que a ela se seguiram a tomam como ponto de partida crucial, uma espécie de divisor de águas na historiografia sobre a pintura ${ }^{4}$. E não é de se espantar que tamanho tenha sido seu impacto: não se tratava apenas de uma análise de Las Meninas, mas também de uma reflexão filosófica sobre as condições e limites da representação clássica. Nas palavras do filósofo, em Las Meninas "talvez haja [...], como que a representação da representação clássica e do espaço que ela abre ${ }^{5 "}$. E, para chegar a essa conclusão, Foucault constrói, de maneira hábil, uma interpretação minuciosa do

3 FOUCAULT, Michel. As Palavras e as Coisas: uma arqueologia das ciências humanas, 8a ed., trad. Salma Tannus Muchail. São Paulo: Martins Fontes, 1999.

4 Reúno alguns dos escritos relevantes sobre Las Meninas que tomam a análise de Foucault como um divisor da águas: ALPERS, Svetlana. "Interpretation without Representation, or the viewing of Las Meninas", Representations, i, 1 (1983), pp. 34-46, DAMISCH, Hubert. L'Origine de la Perspective, Flammarion, Paris, 1987, pp. 387-407; SEARLE, John R., "Las Meninas and the Paradoxes of Pictorial Represetation", Critical Inquiry, 6, no. 3 (1980), pp. 477-488, SYNDER, Joel; COHEN, Ted. "Critical Response. Reflexions on Las Meninas: Paradox Lost, Critical Inquiry, 7, no. 2, (1980), pps. 539-572; SNYDER, Joel. "Las Meninas and the Mirror of Prince". Critical Inquiry, Vol. 11, No. 4 (1985); STEINBERG, Leo. "Velázque's Las Meninas", October, 19 (1981), pp. 45-55.

5 FOUCAULT, Michel. Op cit., p. 20. 
quebra-cabeça epistemológico da pintura baseando-se na descrição de cada um de seus elementos para destrinchá-los em vista da complexa tessitura da composição.

Se o impacto das reflexões de Foucault se fez prontamente sentir nos estudos de filosofia e mesmo no campo disciplinar da história da arte, não podemos presumir que o mesmo tenha acontecido no que concerne à fortuna crítica da série de Picasso. Ainda que ela hoje seja um dos highlights do Museu Picasso Barcelona, são escassas as críticas e estudos dedicados à série e mesmo seu impacto sobre a produção artística não parece ter sido relevante de imediato.

Não por acaso, portanto, dentre os poucos estudos monográficos sobre Las Meninas de Picasso, a maioria parte justamente do texto de Foucault como parâmetro de análise ${ }^{6}$. Ora, e por que não? Como Foucault, que estava preocupado em estabelecer as condições e os limites da representação clássica, Picasso, co-fundador do cubismo, jamais deixaria passar por alto os desafios de uma equação enigmática entre "aparência, verdade e realidade"7 , ou em outras palavras, entre "signo pintado e seu significado simbólico" ${ }^{8}$. Não foi ele, Picasso, afinal de contas, o grande inventor da colagem, o artista que testou todos os parâmetros do espaço real e criticou até mesmo o cubismo analítico por ser "basicamente em perspectiva" 9 ? A conexão é tentadora. E as ressonâncias entre as indagações de Foucault e as inquietações que Picasso havia expressado a Penrose alguns anos antes tornam a comparação ainda mais irresistível.

6 A mais conhecida e a mais minuciosa das interpretações que utilizam o texto de Foucault como ponto de partida para as análises de Las Meninas de Picasso é a de Susan Grace Galassi, que, dentre os escassos trabalhos monográficos sobre a série, é o que obteve maior relevância. Cf. GALASSI, Susan Grace. "Picasso in the Studio of Velázquez", in Picasso and the Spanish Tradition, Jonathan Brown (ed.), New Haven e Londres: Yale University Press, 1996. Para além do estudo de Galassi e frente à proeminência da leitura de Foucault, um número considerável de leituras de Las Meninas de Picasso em chave estruturalista se consolidaram. Cito UTLEY, Gertje J., "Las Meninas in Twentieth-Century Art", em Velázquez's Las Meninas, ed. Sazanne Stratton-Pruitt. Cambridge: Cambridge University Press, 2003, pps. 171-202; KLEINFELDER, Karen K., The Artist, his model, her image, his gaze: Picasso's pursuit of the model. Chicago: The University of Chicago Press, 1993, pps. 57-67; OCAÑA, Maria Teresa. "La violación de Las meninas", em Picasso, Las Grandes Series. Madrid: Museo Nacional Centro de Arte Reina Sofía (MNCARS) ; Aldeasa, 2001, pp. 137-157.

7 GALASSI, 1996, op. cit., p. 122.

8 idem.

9 KAHNWEILLER, Daniel-Henry. "Entretiens avec Picasso", Quadrum, n. 2, nov. 1956, p. 74. A respeito da declaração de Picasso, veja-se também KRAUSS, Rosalind. Os Papéis de Picasso, trad. Cristina Cupertino. São Paulo: Iluminuras, 2006, p. 113. 
É curioso, no entanto, que não tenha sido devidamente assinalado que a análise de Las Meninas de Foucault parte de certas observações a respeito de traços fundamentais da pintura de Velázquez que Picasso, em sua série, não tarda em sacrificar. A começar pela unidade espacial: Foucault, de forma refinada, coloca em evidência a existência de certas lacunas estruturais de um sistema composto por elementos - gestos, poses, olhares - aparentemente dispersos que a pintura reúne e exibe em conjunto; nas variações de Picasso, em contrapartida, a própria noção de conjunto está em jogo. Não à toa, Las Meninas de Picasso apresenta-se através da linguagem fracionada de uma série. É como se só pudéssemos evocar o conjunto da obra de Velázquez através da disjunção e do fragmento, rompendo, de início, com qualquer circuito fechado que possa ordenar uma unificação espaço-temporal. Circuito, no caso de Velázquez, fundamental: segundo Hubert Damisch, este é o único quadro do pintor espanhol construído a partir de uma perspectiva estrita, que logo cai em bancarrota por revelar, através de uma rede ardilosa de relações, a faceta inadvertida sobre a qual todo o sistema perspectivo se funda: a admissão de um único lugar assignado ao espectador ${ }^{\text {ro }}$. E Picasso, desde logo e sem qualquer hesitação, elimina de sua interpretação o princípio básico de unidade.

É, portanto, através de um processo de fragmentação que Picasso escolhe interpretar Las Meninas. E se isso não exclui o fato de que esse processo possa ser visto à luz de analogias com o texto de Foucault, devemos também considerar os limites que tal aproximação impõe. A esse respeito tenhamos em vista, outra vez, um alerta de Hubert Damisch: "sem dúvida, a transformação operada por Picasso tem lugar em um contexto totalmente distinto daquele do quadro que lhe fornece matéria prima: a pintura não estava mais, em I957, na era da representação ${ }^{\mathrm{II}}$ ". De fato, os desafios e objetivos compartilhados pela arte, ao menos desde meados do século XX, parecem estar em outro lugar.

Mas é também inquietante - e talvez até mesmo sintomático - que a primeira referência evocada por pesquisadores para analisar a série de Picasso (depois da própria pintura de Velázquez, evidentemente) tenha sido a de um filósofo, e, especialmente, a de um filósofo dedicado, entre muitas outras coisas, a voltar-se às raízes do pensamento moderno ocidental para traçar uma arqueologia de seu desenvolvimento. É claro que,

10 Cf. DAMISCH, Hubert, op. cit., p. 436.

11 ibid., p. 448, traduzido livremente, do original: "Sans doute la transformation de Picasso prend-elle place dans un tout autre context que le tableau qui en a fournit la matière: la peinture n'était plus, en 1957, à l'âge de la representation". 
conforme sinalizado, o interesse de ambos por Las Meninas de Velázquez faz da correspondência entre um e outro uma rota de fuga atraente. À exceção de Foucault, poucas referências adicionais são trazidas à baila: quando muito, aduz-se a certos traços estilísticos e motivos particulares que, em algumas pinturas da série, parecem evocar a obra de Matisse, cuja morte recente (1954) teria abalado profundamente Picasso e o impelido a reavivar uma antiga rivalidade. De resto, são sobretudo trabalhos anteriores de Picasso que explicam a recorrência de certos padrões em Las Meninas.

O elemento instigante, ainda assim, reside precisamente na alusão a Foucault. Longe de resguardar as análises de uma narrativa autorreferencial, ela parece mobilizada sobretudo para reafirmar um ciclo metanarrativo, fazendo do cubismo - entendido mais como uma espécie de estilo atemporal do que como um fenômeno com suas particularidades históricas - uma preocupação legítima para explicar Las Meninas ${ }^{I 2}$. Mas será, de fato, essa saída uma resposta à altura dos desafios suscitados pela série? Ou, antes, não seria ela mesma tributária (ao menos em parte) da dificuldade que temos em responder a certos impasses que o percurso e a trajetória artística de Picasso nos impõem?

Explico-me brevemente. Como se sabe, quando Picasso se propôs a reinterpretar Las Meninas ele já havia, desde ao menos quarenta anos, se afastado do cubismo. Isto é, cerca de quarenta anos antes, parecia evidente - até mesmo a seus contemporâneos, como nos faz ver Rosalind Krauss ${ }^{13}$ - que os anos de guerra, a saber, da Primeira Guerra Mundial, tinham cindido seu trabalho em dois: o período até I9I4, no qual se atesta o desenvolvimento triunfante da lógica do cubismo, e o momento do pós-guerra, anunciado significativamente pela grande exposição individual na Galeria Paul Rosenberg em I9I9, em que sua arte não apenas parecia ter voltado a padrões aparentemente naturalistas, mas também o fazia via “imitação" de um leque de artistas clássicos, de Poussin

12 A exeção é a análise de Hubert Damisch que, não obstante partir do texto de Foucault, escapa por completo da descrição que aqui faço. Desenvolverei esse ponto ao longo do capítulo.

13 KRAUSS, op. cit., pp. 34-43. No capítulo "Picasso/Pastiche" deste livro, Krauss realiza uma minuciosa e arguta discussão acerca da apropriação de Picasso da arte do passado que me parece uma das mais relevantes sobre esse complexo debate. Cumpre, ainda assim, pontuar que a bibliografia sobre o tema é vasta. Elenco, portanto, mais algumas publicações de fôlego sobre o assunto: COWLING, Elizabeth. Picasso: Style and Meaning. Nova York: Phaidon, 2002; CALVOSERRALLER, Francisco. Picasso Tradición y Vanguardia. Madrid: Museo del Prado, 2006. 
a Ingres, conduzida sob a bandeira do pastiche ${ }^{\mathrm{I} 4}$. E se nesse momento a apropriação do antigo acontecia, via de regra, como emulação de um estilo, é sobretudo após a Segunda Guerra Mundial que ela passa a ocorrer com frequência não só no nível da forma como também do conteúdo ${ }^{15}$. São conhecidas as tantas variações realizadas a partir de pinturas de Velázquez, Delacroix, Manet, Cranach e Courbet, só para ficar naquelas realizadas na década de 1950.

A essa altura, Picasso já havia conquistado suficiente fama e prestígio para firmar seu nome no rol de celebridades da história da arte, o que em nada significa que estivesse livre dos tantos detratores que viram em sua obstinada volta ao passado uma incapacidade de enfrentar e compartilhar os desafios da arte do presente. Na década de I960, não só Clement Greenberg, um dos que contribuíra decisivamente para firmar o nome de Picasso na genealogia da arte moderna, havia acusado o trabalho do artista de sucumbir a um desgaste patente ${ }^{16}$, mas também críticos cujo pensamento se assentava nas mais diversas correntes identificaram em seu percurso o derradeiro indício de uma queda anunciada ${ }^{17}$. A história teria driblado Picasso.

Não que os bastiões da arte de Picasso tenham jamais deixado de existir. E em meio a uma cisão pronunciada entre os que consideravam a produção "tardia" de Picasso como a mais alta expressão de uma mão indomável e os que simplesmente optaram por não

14 Cumpre sinalizar que a suposta "volta" de Picasso a modelos naturalistas, denunciada por críticos já em meados de 1910, não é, como argumenta Krauss, de todo procedente. Isso porque em certos retratos da época, sobretudo os de Olga Koklova, Picasso mostrava ter internalizado a inteligência cubista e era capaz de manejar com desenvoltura o cubismo como "código de representação", como o fazia com os códigos naturalistas em questão. Cf. KRAUSS, op. cit.

15 Refiro-me sobretudo à recorrência com que isso passou a ocorrer após a Segunda Guerra Mundial e a dimensão das empreitadas que essa volta ao passado adquiriu, já que, como se sabe, a apropriação de temas e estilos da história da arte ocorre desde a produção inicial de Picasso.

16 Greenberg não critica somente a "abjeção 'pastichosa'" de Picasso, mas também muitos outros pontos: a falta de unidade estilística tanto no trabalho como um todo mas em pinturas específicas, o traço desdenhoso, confuso e predatório, o ilusionismo fácil, entre muitos outros, e o diagnóstico final não é otimista. Nos diz o crítico: "talvez Picasso tenha sucumbido ao mito de si próprio, como tantos de seus admiradores propagaram: a de que ele é um semideus que pode fazer qualquer coisa e que, portanto, não é suscetível a fraquezas". Cf. Clement GREENBERG. "Picasso aos 75 anos" [1957] , em Arte e Cultura: Ensaios Críticos. São Paulo: Editora Ática, 1996, , p. 83.

17 Cf. BERGER, John. The Success and Failure of Picasso. Nova York: Pantheon Books, 1965. Consideremos por exemplo: "Foi nessa época que Picasso começou a caricaturar a arte européia, a arte dos museus. Inicialmente [...] ele caricaturizou Ingres" 
a considerar, o trabalho do artista passou a ser frequentemente lido em chave endógena. A autobiografia, como um estudioso chegou a sugerir ${ }^{18}$, converteu-se em metodologia canônica nos estudos sobre Picasso. Se algo compartilham tanto os best-sellers de folhetim como grande parte da literatura mais influente (que, diga-se de passagem, produziu reflexões das mais refinadas ${ }^{19}$ ) sobre o legado do artista é que ambos, a partir de certo momento, passaram a legitimar Picasso por Picasso - seja pela obra ou pela vida ${ }^{20}$. O preço a se pagar, evidentemente, é o da inflação.

É claro que não apenas de biografia sem lastro se fez a vasta literatura sobre este que foi um dos mais renomados artistas do século XX. Escapando à linha que separa os bajuladores de plantão e os impacientes com a pedra nas mãos, muitos foram os que se dedicaram a compreender o trabalho de Picasso em sua complexidade, para além de dicotomias infames. Isso sem contar os sucessivos esforços de desconstrução que, no campo disciplinar da história da arte, lhe foram reservados a partir de meados da década de 1970 e que, durante ao menos três décadas, fizeram de sua obra arena privilegiada para discussão das contendas do modernismo ${ }^{21}$.

O que tampouco nos isenta daqueles desafios a que me referia no início - e que, para os que se propõem a analisar Las Meninas, como é o caso, fazem-se incontornáveis. De um lado, a série aparenta estar tão afastada dos impasses compartilhados pela

18 Cf. VARNADOE, Kirk. "Picasso's Self-Portraits", in Picasso and Portraiture: Representation and Transformation, William Rubin (org.). Nova York: The Museum of Modern Art, 1996, p. 147.

19 Refiro-me, por exemplo, a grande parte do conjunto de escritos de William Rubin acerca da obra de Picasso, que situam muitas das interpretações de trabalhos a partir de um enfoque biográfico. Entre eles: RUBIN, William Stanley. Demoiselles d'Avignon. Nova York: Museum of Modern Art, 1994; RUBIN, William. Picasso and Portraiture: Respresentation and Transformation, Nova York, Paris: The Museum of Modern Art, Musée Picasso, 1996.

20 Sobre a crítica da autobiografia como chave interpretativa para a obra de Picasso, veja-se KRAUSS, Rosalind. "In The Name of Picasso", in October, Vol. 16, Art World Follies (Spring, 1981), pp. 5-22.

21 Refiro-me sobretudo aos empenhos de revisão da historiografia suscitados pela emergência dos debates feminista e pós-colonialista. Mas devemos ter em vista, também, que a obra de Picasso, por tudo que tem de paradigmática, pode - como em alguns casos foi também ser tomada como campo fértil para a revisão das ideias de estilo, individualidade, fase, desenvolvimento, classicismo, virilidade, modernismo tardio, cultura de massa, que frequentemente subjazem os estudos em história da arte. O assunto foi tratado por SALZSTEIN, Sônia. A presença enviesada da obra de Picasso no debate da arte dos anos 1980 à atualidade: Algumas questões teóricas. In: XXXI Colóquio do Comitê Brasileiro de História da Arte. Museu Nacional de Belas Artes, Rio de Janeiro, 2010. 
produção artística de seu próprio tempo que qualquer paralelo que se busque estabelecer soa ostensivamente forçoso se prescindidas as mediações. Por outra parte, utilizar-se do próprio trabalho de Picasso como única autoridade para a análise (e das referências de Foucault e Velázquez para comungá-lo) me parece arriscado, sob a pena de incorrer num discurso de autossuficiência que escamoteia seu fundo laudatório e que não só é insuficiente para a compreensão de Las Meninas, como também, em última instância, ignora todo um debate de relevância acerca da obra do artista. Ora, mesmo os estudos mais recentes sobre a série (contemporâneos ou posteriores aos esforços de desconstrução a que nos referimos há pouco) amiúde levam a reboque a cepa dos raciocínios engastados na literatura mais consagrada sobre Picasso.

Some-se o fato de que, no contexto geral da trajetória do artista, a série é, não raro, tida como mais um daqueles grandes empreendimentos a partir de obras-primas do passado, maneira encontrada pelo septuagenário Picasso para medir-se com os antigos mestres e firmar seu lugar ao sol. Iniciativa de alguém menos preocupado em dialogar com seus contemporâneos que em consolidar sua grandiosidade sob os auspícios da ilustre narrativa da história da arte ${ }^{22}$. E a conhecida aversão de Picasso tanto pela obra de Marcel Duchamp quanto pela arte abstrata, como era de se esperar, só vem a adular as estacas desse argumento ${ }^{23}$.

Mas até que ponto seriam as tantas séries de variações que Picasso realiza na década de 1950 uma reivindicação de maestria? Uma alternativa à questão foi oferecida, já há mais de duas décadas, por Rosalind Krauss. Ela refere-se, entre outras coisas, às variações realizadas por Picasso a partir de Le Déjeneur sur l'herbe, entre 1959-1962²4. Para a autora,

22 Considere-se, por exemplo: "Out of the step with contemporary avant-gard, Picasso appears to have felt greater anxiety about how he would measure up against those who, in his eyes, really mattered - the great masters", em COWLING, op. cit., p. 638. Mesmo em seu estudo monográfico sobre Las Meninas, Galassi parece concordar com esse ponto. Vide seu comentário: "Nowhere, however, is Picasso more revealing of his obsession with the history of art as a living process than in his variations on painting of the past. Through them, he not only reflects on history, and his place in it, but encloses himself within it. In his variations [...] Picasso makes history as he makes art". Cf. GALASSI, op. cit., p. 83.

23 Sobre a conhecida aversão de Picasso à abstração, veja-se BOIS, Yve-Alain. Picasso et l'Abstraction. Colloque Revoir Picasso, 27 mars 2015.

24 KRAUSS, Rosalind. "The im/pulse to see", in Vision and Visuality: Discussions in contemporary culture, ed. Hal Foster. Washington, DIA Foundation, 1988, pp. 51-79. Alguns anos mais tarde, a autora desenvolverá o argumento desse texto no quinto capítulo de seu livro sobre o inconsciente óptico. Cf. KRAUSS, Rosalind. The Optical Unconsciouss, Cambridge: MIT Press, 1994, pp. 197-243. 
os inúmeros desenhos dessa série, ao contrário do que possa parecer (e do que efetivamente parecera à crítica), não obedecem à lógica da imposição de maestria renovada pela inspiração de um mestre criador. Construindo uma argumentação complexa e surpreendente, a autora nos mostra como eles, talvez à revelia do artista, não deixam de responder a questões semelhantes àquelas que permeiam o trabalho de artistas frequentemente acomodados sob a rúbrica de linhagens opostas às de Picasso, como Duchamp e Max Ernst.

E quanto a Las Meninas? Embora a série, a princípio, não nos dê grandes evidências de que esteja efetivamente em diálogo com os objetivos da arte de seu tempo, deveríamos render-nos a que assim o seja? Ora, mas toda a arte - que o negue ou o afirme - pertencerá inequivocamente a seu tempo, poderia se responder. Nem mesmo o gênio de Picasso o torna imune à história. Essa parece a resposta mais fácil, se não imediata, mas se assim for, de que modos precisamente isso acontece?

Proponho lançar-me ao desafio de responder. Para tanto, é necessário dirigir-me novamente a Las Meninas, afastando-me, de início, do pano de fundo histórico e artístico no qual a série reluta em moldar-se. Pois se ela não oferece rota de fuga que leve diretamente a uma saída para as questões colocadas, nada melhor que imergir em sua evidência material. Talvez então o embate com as obras nos permita extrair o que, em um primeiro momento, é de difícil adução. O percurso, no entanto, exigirá paciência, pois demandará a atenção descritiva de um olhar rente e quiça mesmo vagaroso.

Delineados os objetivos, parto para algumas breves considerações sobre a estrutura da dissertação, dividida em dois grandes capítulos. O primeiro é como um mergulho contíguo a Las Meninas, e concentra-se quase que exclusivamente em uma extensiva análise das quarenta e oito pinturas que compõem o conjunto. Esse capítulo é dividido em três sessões que acompanham, de modo mais ou menos linear, o andamento da série. Nas duas primeiras sessões, dedico-me a descrever e examinar as pinturas individualmente ou em pequenos conjuntos. A empreitada pode soar extenuante, mas considerando que muitas das interpretações que hoje temos da série prescindiram de um olhar rente às obras, julgo pertinente fazê-lo. De todo modo, busco não perder do horizonte as discussões levantadas pela literatura mais específica sobre a série, e trazendo também à tona, por vezes, discussões de relevância que marcaram a interpretação da obra de Velázquez 
ou de outras obras do passado. Algumas questões específicas ancoram a discussão: a mais importante talvez seja a articulação dos olhares que entretecem as pinturas da série, e sua relação com o papel do olhar do espectador fora do quadro. Quanto a esse ponto, quiçá Las Meninas de Velázquez seja uma das pinturas mais enigmáticas que conhecemos, e Picasso, sem hesitação, mantém faro agudo e alerta para a questão. Não é de admirar: era em sua produção, cinquenta anos antes, com a pintura Les Demoiselles d'Avignon(I907), que se revelava um novo regime de visualidade, no qual o espectador é arrebatado "para dentro do quadro" em um imediatismo brutal. "Nenhuma outra pintura moderna (exceto Las Meninas) se dirige ao espectador com intensidade comparável 25", diz Leo Steinberg a respeito de Les Demoiselles. E sua menção a Las Meninas de Velázquez, por mais circunstancial que seja, não é de se descartar. A terceira sessão deste primeiro capítulo, portanto, pretende reestabelecer certos elos entre Las Meninas de Picasso e o restante da trajetória do artista, dedicando especial atenção ao debate instaurado por Demoseilles e, especificamente, pela revigorada interpretação (1972) que Leo Steinberg dá à pintura.

O segundo e último capítulo, por sua vez, empenha-se em desenvolver reflexões que emergem do olhar rente a Las Meninas e das discussões anteriores. Nele, me arrisco a certas análises comparativas entre a série e obras de outros artistas, buscando compreender como determinadas questões levantadas no capítulo precedente articulam-se em um debate mais amplo sobre a obra de Picasso e sobre seu papel no desenvolvimento da arte contemporânea. Arrisco-me ainda, a modo de conclusão, a fazer uma breve incursão em certas gravuras e desenhos realizados nos últimos anos de vida de Picasso, nos quais tramas de olhares e o olhar voyeurista do espectador amiúde estruturam as composições Espero que o exercício seja proveitoso.

25 STEINBERG, Leo. "The philosophical brothel", in October, Vol. 44, Primavera de 1988 (1972), p. 11. 


\section{Capítulo I - Las Meninas, 1957}

\section{A SÉRIE: PARTE I}

\section{A infanta: gestos, pose e olhar}

Biógrafos contam que entre os meses de agosto e dezembro de I957, Picasso retirou-se do habitual recinto de seu ateliê para recolher-se no último andar de sua suntuosa residência em Cannes, conhecida como La Californie ${ }^{26}$. Nesse período, recebeu poucas visitas e se manteve quase que unicamente restrito ao convívio de seus pombos de estimação e de Jacqueline Roque, sua companheira no momento. A iniciativa atendia a um objetivo em radar: concentrar-se exclusivamente na realização de uma ambiciosa série de variações de Las Meninas, obra-prima de seu predecessor e conterrâneo Diego Velázquez. $\mathrm{O}$ ciclo de isolamento resultou em cinquenta e oito pinturas: um corpo de obras aparemente heterogêneo, composto de quarenta e cinco interpretações derivadas diretamente da pintura de Velázquez, nove pinturas de pombos retratados a partir da vista do aposento em que trabalhava em La Californie, três paisagens e um retrato de Jacqueline. Todas foram meticulosamente datadas e ordenadas segundo critérios estabelecidos pelo próprio artista, que as concebia como conjunto e que, anos mais tarde, as doou ao Museu

26 PENROSE, Roland, op. cit., p. 494. 
Picasso Barcelona ${ }^{27}$. Hoje, Las Meninas compõem a única série de Picasso que se encontra preservada em sua integridade em um mesmo acervo ${ }^{28}$.

A primeira pintura da série (fig. 2) data de I7 de agosto, e consiste em uma tela de grandes proporções (a maior desde a finalização de Guernica, em I937 ${ }^{29}$ ) dominada por uma paleta em tons sóbrios (cinzas, pretos e brancos). Picasso parece, antes de mais nada, querer realizar uma espécie de mapeamento da obra de Velázquez e de sua estrutura, buscando uma compreensão totalizante das coordenadas espaciais e procurando situar em sua própria pintura cada uma das figuras presentes na obra de Velázquez. Dispõe todas elas, de início, em uma tela horizontal cujo formato difere radicalmente da original ${ }^{30}$ (mais equilátera que a de Picasso, se vista comparativamente). Em meio à amplitude espacial que se descortina da mudança de proporções, vemos engrandecida a figura do pintor, Velázquez. Ele ocupa quase todo o terço esquerdo da composição e é consideravelmente maior que qualquer outra figura à sua volta. Não obstante, seu corpo e rosto parecem imiscuir-se na espacialidade difusa do quadro. Nas próximas quarenta e quatro variações de Las Meninas, a figura de Velázquez aparecerá somente três vezes, e sem qualquer protagonismo. Desde já, Picasso assinala sua desaparição. E repare-se: justo ele, peça tão importante para o quebra-cabeça epistemológico da análise que Michel Foucault faz de Las Meninas.

Da distensão da porção horizontal da pintura resulta também uma nítida composição triangular, em cujo centro localiza-se a radiante figura da infanta Margarita Maria.

27 A ação de manter a série unida e doá-la para Barcelona partiu do próprio Picasso em 1968, após a morte de Jaimes Sabartés, seu grande amigo catalão que tinha como projeto a criação de um museu monográfico sobre Picasso na cidade onde se conheceram. Para informação atualizada sobre a relação entre Picasso e Sabartés e a criação do Museu Picasso Barcelona, veja-se "Sabartés por Picasso por Sabartés - Arxiu Museu Picasso Barcelona", GUIGON, Emanuel; CORTADELLA, Margarida; CASACUBERTA, Margarida; IDMHAND, Fátima; GUAL, Malém; RAFART, Claustre, DOMÈNECH, Silvia. Fundació Picasso Barcelona, 2018.

28 Uma relação cronológica das variações, na qual consta a data precisa de realização de cada uma das obras, pode ser consultada no blog do museu, através do endereço: http:// www.blogmuseupicassobcn.org/2015/08/la-cronologia-de-las-meninas-de-picasso-2/?lang=es. Consultado em março 15 de março de 2018.

29 Confio essa informação a GALASSI, op. cit., p. 126.

30 Utilizo o termo original ao longo deste capítulo com um sentido estritamente denominativo para facilitar a distinção entre obras de um mesmo nome, considerando que Las Meninas de Picasso teve como modelo uma obra originalmente pintada por Velázquez. É claro, no entanto, que a série de Picasso não tem qualquer pretenção de cópia, e é, portanto, também um original. 



2 Las Meninas

Cannes, 17 de agosto de 1957

Óleo sobre tela

$194 \times 260 \mathrm{~cm}$

Museu Picasso, Barcelona

3 Las Meninas [infanta Margarita María] Cannes, 20 de agosto de 1957

Óleo sobre tela

$100 \times 81 \mathrm{~cm}$

Museu Picasso, Barcelona 
Imediatamente acima dela, vemos, à contraluz, uma silhueta em sombras que irrompe da porta aos fundos do aposento. Ela corresponde, no quadro de Velázquez, a uma figura identificada como José Nieto Velázquez, o aposentador ${ }^{31}$ da rainha. A relação entre ele e a infanta será obstinadamente trabalhada e retrabalhada por Picasso, conforme demonstraremos adiante. Por ora, basta sinalizar que após realizar sua primeira variação de Las Meninas, Picasso pintará vinte e oito telas em menor formato até retornar a coordenar todas as personagens da pintura de Velázquez em uma mesma composição.

A segunda pintura, realizada quatro dias depois, marca o primeiro ponto de virada em Las Meninas. Não é mais o conjunto ou a estrutura da obra de Velázquez que passam a interessar a Picasso: daqui em diante, o artista se detém majoritariamente na apuração da postura, dos gestos e das expressões de figuras individuais, decompondo em partes aquilo que antes se via conjugado. Nem todos, no entanto, são submetidos a seu feroz escrutínio. São sobretudo as figuras femininas ligadas ao séquito da infanta as escolhidas para a inspeção individualizada ${ }^{32}$. Nessa empreitada, a pequena figura da infanta é certamente uma das que mais o instiga. Ela está presente em vinte e oito das quarenta e cinco variações, e é a única retratada em quatorze delas. Sua pose é visitada e revisitada por Picasso: ele ora a retrata de corpo inteiro, como se buscasse apreender sua pose em poucos gestos, ora focaliza sua expressão facial em detalhe, como se em seu rosto encontrasse um nódulo expressivo. Nessa empreitada, os olhos da menina por vezes abreviam-se a um ou dois pontos expressivos. Em outros casos, um de seus olhos infla, arregala-se, enquanto o outro reduz-se a um ponto cego, um globo estéril interceptado pela linha do perfil. É como se um deles fosse maculado para que o outro revestisse o olhar

31 O aposentador real, ou "mariscal de palacio" é um cortesão encarregado de diversas funções na corte espanhola, entre elas abrir os aposentos para o casal real, cuidar de coleções específicas, etc. Ao buscar por uma palavra para expressar função correlata em português, não encontrei correspondentes. Em francês, a palavra chambellan poderia ser utilizada como tradução, ainda que as funções de um e de outro não correspondam tal e qual.

32 O anão Nicolás Perusato figura em uma das variações individualizadas, tendo sido a inspiração para outra pintura da série na qual vemos uma figura ao piano. Nem o Rei Felipe, nem o pintor, nem José Nieto e nem o guardadamas ao lado da camareira maior são alvos de escrutínio analítico. 
de intensidade. Lançando mão de um obstinado espírito inquisitivo, Picasso vale-se de um procedimento que o fez célebre, de condensação entre a posição frontal e o perfil 33 .

A segunda pintura da série (fig. 3), portanto, é destinada à figuração da infanta. Picasso a retrata da cintura para cima, utilizando-se da mesma palheta de tons monocromáticos da pintura anterior. Agora a infanta é sultimente deslocada do eixo central da tela, de modo a enfatizar, no canto inferior esquerdo da composição, um detalhe expressivo fundamental: vemos, quase que de relance, sua mão direita ligeiramente suspensa, absorta, erguendo-se no preciso momento em que segura um búcaro ${ }^{34}$ que lhe é oferecido por alguém fora de campo, cuja mão é o único elemento visível na pintura. Seu olhar, no entanto, não atende ao emissário que lhe oferece água, mas direciona-se ao próprio espectador, numa expressão interrogativa. O gesto de suas mãos não parece atender a qualquer movimento premeditado: temos a sensação de vê-la no preciso instante em que ela desvia a atenção de seus modos para contemplar aquilo que lhe sucede diante dos olhos. Como se ela, de imediato, fosse arrebatada em um estado de paralisia, deflagrada em movimentos e olhares disruptivos.

Na seguinte variação(fig.4), o emissário fora de campo cujas mãos havíamos visto na pintura anterior revela-se ao nosso olhar. Trata-se de Maria Agustina Sarmiento, dama de companhia da infanta, com seus dedos inchados e com os olhos descompassados mirando em diagonal, na direção em que outrora situava-se a pequena garota. Novamente, Picasso utiliza a paleta em tons acinzentados, mas desta vez, sobrepõe aos grises uma mescla de tons primários ligeiramente esmaecidos (detalhes em amarelo e vermelho, um fundo azul claro), como em uma fotografia antiga em preto e branco que foi posteriormente pintada a lápis de cor. Esse tratamento confere à cena um ar atmosférico e mesmo onírico que contrasta com a dura instantaneidade das pinturas anteriores.

33 Tomo como principal referência para a discussão deste procedimento as reflexões de Leo Steinberg acerca da série Femmes d'Alger, de Picasso. Veja-se STEINBERG. Leo. "As Mulheres Argelinas de Picasso em aberto", em Outros Critérios, trad. Célia Euvaldo. São Paulo: Cosac Naify, 2008, pp. 163-289. Em relação ao assunto, veja-se também STOICHITA, Victor. Breve História da Sombra. Lisboa: KKYM, 1997, pp. 116-117.

34 O búcaro é um tipo de vasilha de argila proveniente das Índias Orientais. Sua figuração remete a conotações sexuais. Sobre a relação entre este objeto e sua conotação erótica, ver GALASSI, op. cit., p, 131. Joel Snyder aponta que o búcaro era produzido a partir de argila terracota importada das índias orientais, e, uma vez que bebia-se seu conteúdo, comia-se o objeto para que a argila embranquecesse a pele, dando-Ihe um tom mais branco e, em um território governado pelos habsburgos, mais régio. SNYDER, Joel, op. cit., p. 539. 

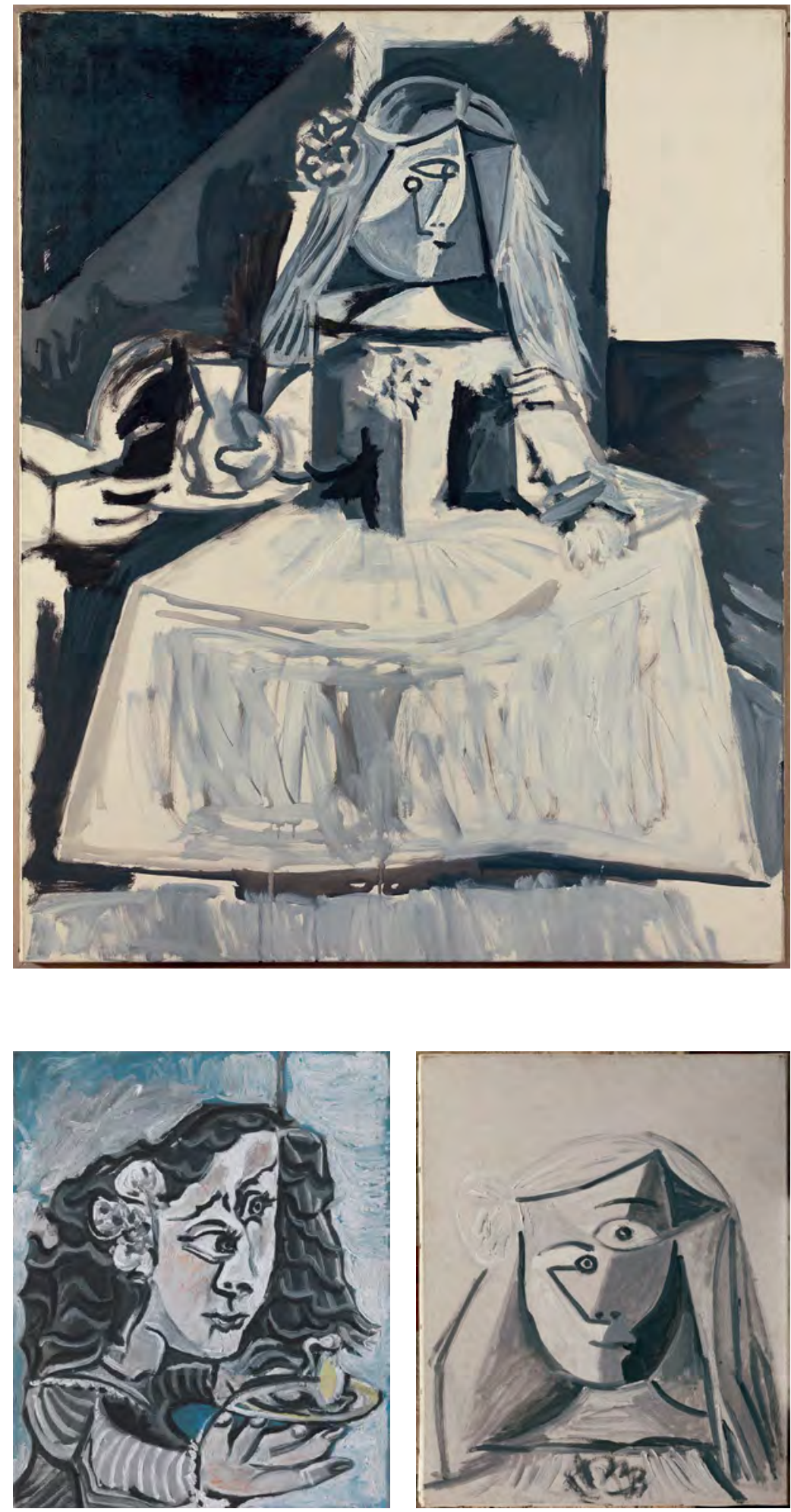

4 Las Meninas [infanta Margarita María] Cannes, 21 de agosto de 1957

Óleo sobre tela

$100 \times 81 \mathrm{~cm}$

Museu Picasso, Barcelona
5 Las Meninas [María Agustina Sarmiento] Cannes, 20 e 26 de agosto de 1957

Óleo e lápis gorduroso sobre tela $45,9 \times 38 \mathrm{~cm}$

Museu Picasso, Barcelona

6 Las Meninas [infanta Margarita María] Cannes, 27 de agosto de 1957

Óleo sobre tela

$41 \times 33 \mathrm{cmW}$

Museu Picasso, Barcelona 

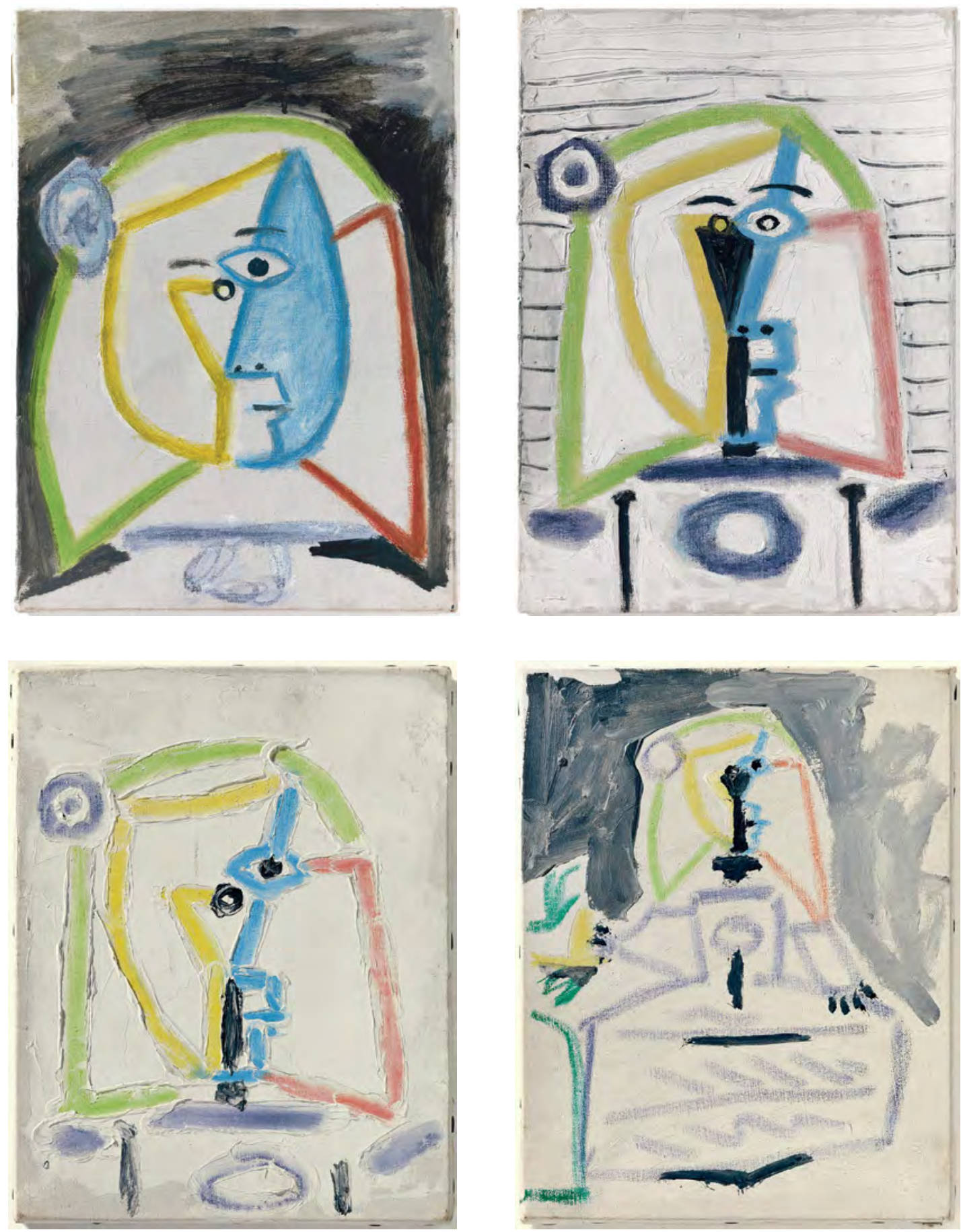

7 Las Meninas [infanta Margarita María] Cannes, 27 de agosto de 1957

Óleo e crayon sobre tela $33 \times 24 \mathrm{~cm}$

8 Las Meninas [infanta Margarita María] Cannes, 27 de agosto de 1957 Óleo e crayon sobre tela $33 \times 24 \mathrm{~cm}$

10 Las Meninas [infanta Margarita María]

9 Las Meninas [infanta Margarita María] Cannes, 28 de agosto de 1957

Óleo e crayon sobre tela $18 \times 14 \mathrm{~cm}$

1957

Óleo e crayon sobre tela

$18 \times 14 \mathrm{~cm}$ 
É justamente então que somos levados de volta à imagem da infanta (fig. 5). Ela, doravante, é vista de corpo inteiro, outra vez agarrando o búcaro e olhando em nossa direção. Ato contínuo, vemos a princesa novamente, mas de um ponto de vista ainda mais próximo que o anterior (fig. 6). Em seu rosto transparece uma expressão interrogativa, materializada pela espessura condensada da tinta cimentada.

No que se segue, Picasso insistirá em perscrutar obstinadamente a imagem do rosto da menina e se utilizará de telas pequeniníssimas, que parecem como objetos em miniatura. A palheta modulada em tons de cinza - que antes conduzia a um efeito atmosférico - é trocada por um idioma linear e diagramático no qual predominam cores puras (fig. 7). Entre os dias 27 e 28 de agosto de I957, realizará cinco variações (figs. 8-IO) em que este estilo prevalecerá. Em um intervalo de onze dias, terá pintado nada mais, nada menos que onze telas, nove das quais dedicadas a um ferrenho esquadrinhar da imagem da infanta. O gesto disparatado de suas mãos e sua expressão interrogativa, nessa empreitada, são aquilo que permanece no ar.

\section{E quanto a Velázquez?}

Não é de se espantar que a pequena figura da infanta Margarita Maria - com seus gestos, postura e olhar enigmáticos que tanto atinaram a Picasso - tenha sido alvo, desde logo, da atenção daqueles que se propuseram a interpretar Las Meninas de Velázquez.

“A princesa não parece querer aceitar o copo 35 " que lhe oferecem, foi dito. Ela está em um "ambiente informal e em um momento de intimidade, determinado pelo aposento e pelas pessoas presentes" ${ }^{36}$; ela olha para fora de canto de olho no momento em que aceita um copo d'água, percebe-se observada e, no entanto, não adota "uma postura apropriada para exibição" 37 - também foi dito. Ou então: sua postura é intrigante, seu corpo ergue-se em uma rigidez tesa e frontal, açulada pelo ângulo ligeiramente oblíquo

35 EMMENS, J. A. "Las Meninas de Velázquez: Espejo de Príncipes para Felipe IV", em Otras Meninas, Fernando Marías (org.). Madrid: Ediciones Siruela, 2007, p. 63.

36 VAHLE, Bo. "Las Meninas de Velázquez: observaciones sobre la escenificación de un retrato real", in Fernando Marías (org.), op. cit., p. 164.

37 Cf. SNYDER, op. cit., p. 542. Snyder se refere não somente à infanta, mas ao conjunto de figuras na pintura. Traduzido livremente, do original: "their response to being seen is not accompanied by a posture appropriate to being shown" 
de seu rosto, o que gera um "estranho efeito de deslocamento entre a posição de sua cabeça e a direção de seu olhar ${ }^{38 "}$.

Por sua disparatada espontaneidade ou mesmo informalidade - que num primeiro momento parecia soar tão distante dos códigos de apresentação monárquicos da época de Velázquez - a figura da infanta de pronto instigou os estudiosos, levando-os a formular: seria a princesa o motivo central de Las Meninas?

Um dos primeiros - talvez mesmo o primeiro ${ }^{39}$ - a responder à questão foi o tratadista Antonio Palomino (I655-1726), o mais antigo biógrafo de Velázquez. Segundo ele, não há dúvidas de que a princesa, que ocupa lugar central na composição, seja também o tema central da pintura ${ }^{40}$. Palomino fala de imortalização - não da infanta, mas de Velázquez por meio da infanta. O que não exclui o fato de Las Meninas ser, naturalmente, o retrato de Margarita Maria, cujo nome prestigioso é a prenda da glória futura do pintor.

Uma solução diferente - em geral, tida por grande parte da fortuna crítica como marco fundador das interpretações sobre Las Meninas - foi traçada dois séculos mais tarde pelo historiador da arte alemão Carl Justi.4․ Em seu célebre Velázquez y su Siglo (I888), Justi recorre a uma pequena historieta para descrever a pintura: certo dia o rei e a rainha vieram posar para Velázquez e, aborrecidos pelo tédio das sessões de pintura, solicitaram ao pintor que a infanta se unisse a eles para dissiplar-lhes o fastio. Enquanto posavam, viram a luz se configurar de uma forma surpreendente e o rei, que era também meio artista, antevendo um retrato surpreendente de sua sucessora, pediu a Velázquez

38 BROWN, op. cit., p. 71.

39 O mais antigo escrito encontrado até a presente data sobre Las Meninas consta no tratado de pintura do português Félix da Costa (1696), e consiste em uma pequena descrição da pintura. Nessa descrição, ele faz um breve comentário que diz que "o quadro é mais um retrato de Velázquez que o de uma imperatriz. Alguns inventários de pintura do palácio de Prado também fornecem suscintas e objetivas descrições, que amiúde chamam atenção ao fato de que Velázquez se retrata no quadro. A publicação de Palomino (1724), não obstante, é situada como um primeiro esforço de interpretação da obra em sentido mais abrangente. Cf. STRATTON-PRUITT, Suzanne L. Introduction, op., cit., p. 2-3.

40 PALOMINO, Antonio. Velázquez: Biografías de los Siglos XVII y XVIII. Homenaje en el Tercer Centenario de su muerte. Madri: Instituto Diego Velázquez, 1960, p. 70.

41 Somente para citar alguns dos textos que elencam os escritos de Carl Justi como os primeiros de relevância a respeito do quadro: EMMENS, op. cit., BROWN, op. cit., VAHLNE, Bo. "Velázquez' Las Meninas remarks on the staging of a royal portrait", Journal of Art History, vol. 51, 1982, pp. 21-28. 
que representasse aquele momento como uma recordação. Desfecho da estória: Las Meninas não deixa de ser um retrato da infanta, porém, somente enquanto registro impulsionado pelo acaso.

Mas seria possível que Las Meninas fossem, de fato, testemunho de um instante passageiro? Aos olhos do século XX, dificilmente. Pois entendia-se, por então, que a fortuna jamais poderia ter desempenhado um papel tão determinante para uma pintura no século XVII, quando a máxima ut pictura poiesis regia os princípios da invenção ${ }^{42}$.

De sorte que a interpretação de Justi, com o tempo, passou a ver vista como representante por antonomásia de uma leitura impressionista da obra de Velázquez, segundo a qual Las Meninas seria um instantâneo da vida palaciana, uma espécie de registro fotográfico avant la lettre. Essa atitude é expressa pela célebre frase de Théophile Gautier: "En face des Ménines on est tenté de dire: Oú est donc le tableau? [Diante de Las Meninas, somos tentados a dizer: Onde, então, está o quadro?]”33. No século XIX era comum que se exaltasse o apelo naturalista do quadro, sua "presença real", sua refinada aparência elementos que faziam lembrar os experimentos de Daguerre.

(Nunca é demais recordar que Picasso, embora fosse conhecido por "matar o século XIX ${ }^{44}$ ", não somente nascera como também recebera a maior parte de sua formação artística - ao menos oficialmente - na Espanha finisecular ${ }^{45}$. Nada que não acuse seu comentário: "Que quadro! Que realismo! Que proeza maravilhosa".)

O século XX, de todo modo, deu outra cara às interpretações de Las Meninas. Na medida em que grande parte da fortuna crítica de Las Meninas deixou de ressaltar seu

42 Cf. EMMENS, op. cit., p. 44.

43 Ibid. A respeito da recepção de Las Meninas no século XIX, veja-se também: LUXEMBERG, Alisa. "The Aura of a Masterpiece: The Response to Las Meninas in NineteenthCentury Spain and France, in Velázquez's Las Meninas, ed. Suzanne L. Stratton-Pruitt, op. cit., pps. 8-47.; ALPERS, Svetlana. "Describe or Narrate? A Problem in Realistic Representation", New Literary History, Vol. 8, No. 1, Readers and Spectators: Some Views and Reviews (Autumn, 1976), pp. 15-41.

44 Essa frase é atribuída a Gertrude Stein, e foi citada em: KATZ, Leon. "Matisse, Picasso e Gertude Stein", in Four Americans in Paris, Nova Yok: The Museum of Modern Art, 1970, p. 116.

45 Picasso, nascido em Málaga, na região da Andaluzia, era filho de um pai artista. Sua família mudou-se para La Coruña, na Galícia e, mais tarde, para Barcelona, na Catalunha. Realizou parte de sua formação na Academia La Llontja (1895), em Barcelona, e, em seguida, na Real Academia de Bella Artes de San Fernando (1897-8), em Madri, sem, no entanto, finalizar os estudos em nenhuma. Para uma abordagem biográfica de sua formação inicial, veja-se: RICHARDSON, John. A life of Picasso: 1881-1906, vol. 1. Nova York: A. Knopft Editores, 1991. 
deslumbrande "realismo" relegando a aproximação entre a pintura e a fotografia a uma invenção oitocentista, sua atenção passou a dirigir-se cada vez mais ao "suspense" ou "mistério interpretativo" do quadro. Separando o que asseguram ser o significado da obra no século XVII e sua aparência, vista como um interesse meramente moderno ${ }^{46}$, os estudiosos da pintura passaram a ver a infanta não mais como o motivo central da composição, mas como um entre os tantos elementos ou peças de um complexo enigma epistemológico. De modo que Las Meninas, pintada entre I656 e I657 - descrita por um admirador do século XVIII como "la teologia della pittura 47 ", elevada pelo próprio Museu do Prado à posição de "obra culminante da pintura universal"- se converteu em um estimado ponto crucial para pesquisadores da modernidade, filósofos, geômetras, metafísicos, fotógrafos, semióticos, historiadores políticos e amantes da pintura. É nesse buliçoso ambiente, evidentemente, que surge, em I966, a interpretação de Michel Foucault.

Muitos dos escritos sobre a pintura de Velázquez nos últimos anos (profundamente marcados pelas palavras de Foucault) buscaram compreender o quadro não somente enquanto representação de um acontecimento, mas também como construção, interrogando a intrincada dimensão dos significados que constroem e permeiam a narrativa de Las Meninas - como se fosse possível juntar as peças de um quebra-cabeça para depreender de cada detalhe e minúcia um significado oculto, como se por trás da superfície pictórica residisse uma verdade a ser desvendada ou um sentido a ser revelado.

Alguns, inclusive, passaram a admitir como evidência a separação entre aparência e significado da obra, argumentando que, em grande medida, a força da pintura reside justamente no aparente paradoxo entre forma e conteúdo. É o caso de Jonathan Brown,

46 Consideremos ainda: "To the modern observer, and particularly to the modern artist, this supremely sophisticated composition may be the picture's chief claim to attention. But it is not to be supposed that in the seventeenth century it was devised for its own sake alone, without regard for the meaning of the whole", em KAHR, Madlyn Millner. Velazquez: The Art of Painting. Nova lorque: Harper \& Row, 1976, p. 173; ou, mesmo: "Frente a lo que ocorre com otros cuadros con lienzos ostensivamente representados al revés, [...] en los que falta el 'suspense' o 'misterio', Las Meninas exigen del espectador, por el contrario, el desvelamento del oculto, precisamente porque existe la posibilidad - aunque eternamente discutible - de su revelación a través del espejo", in MARÍAS, Fernando, op cit., p. 263; ou, ainda: "Las Meninas appears to be engaged solely with issues concerning the structure of appearance in painting, but it uses this engagement to create and confirm an intimation of ideality. The painting is a speculation about and around an idea-an idea whose very substance concerns imitation [...]", em SNYDER, Joel, op. cit., p. 564.

47 PAlomino, A. El Museo Pictórico y escala óptica, (1715 - 1724). Madrid: M. Aguilar, 1947, p. 920. 
que em sua refinada análise de Las Meninas busca extrair os significados da obra a partir do que considera sua qualidade formal mais chamativa, isto é, o efeito de instantaneidade que tanto apelo teve aos olhos dos espectadores do século XIX ${ }^{48}$.

Como Justi, Brown recorre a uma historieta para explicar o que se sucede na pintura: a infanta Margarita María comparece ao a posento para observar o artista trabalhando e, em algum momento, pede um pouco de água. Observa o anão Nicolás Pertusato ${ }^{49}$ que se põe a brincar com o cachorro e, quando está prestes a apanhar a jarra oferecida por sua dama de companhia, volta o olhar em direção oposta a ela, atendendo à súbita aparição de seus pais no aposento. Isso, para o autor, explica o "estranho efeito de deslocamento entre a posição da cabeça e a direção de seu olhar" ${ }^{\circ}$. Todos os personagens da pintura, de forma assíncrona, começam a dar-se conta da presença do casal monárquico e, cada qual a sua maneira, reage ao acontecimento: os gestos e olhares das figuras se fixam, organizam-se ou estão a ponto de fazê-lo para vislumbrar os soberanos. Para Brown, portanto, o motivo central de Las Meninas não é, pois, a infanta, mas um acontecimento: a "epifania real"; isto é, a súbita entrada do casal monárquico nos aposentos em que se encontram o pintor, a princesa e seu séquito.

Retomo esse debate e a interpretação de Brown porque ela dentre tantas outras, em específico, me parece atentar precisamente para questões relevantes a serem tratadas adiante na compreensão de Las Meninas de Picasso, embora soe improvável, em um primeiro momento, que essa leitura - fortemente assentada em códigos de representação corteses - possa fornecer quaisquer ferramentas para tanto. Por um lado, a fascinação que a pintura de Velázquez exerce sobre Picasso não provém da ordem de significado da imagem monárquica ou do sentido reverencial que Brown atribui à pintura. Em nenhuma de suas variações encontramos signos incontestes da presença do casal real e o espelho que reflete o rei e a rainha quase não tem lugar na sanha analítica a que Picasso submete a obra. Pelo contrário, o objeto é figurado poucas vezes ao longo da série e, quando aparece, é progressivamente reduzido a traços sem qualquer remissão especular.

48 BROWN, Jonathan. "On the meaning of Las Meninas", Images and Ideas in SeventeenthCentury Spanish Painting. Princeton: Princeton University Press, 1978, p. 121.

49 Quase todas as personagens representadas em Las Meninas de Velázquez já haviam sido identificadas no século XVIII, em PALOMINO, El Museo Pictórico, 3 vols., Madrid, 1724. Para informação atualizada sobre a identidade das figuras representadas, ver VAHLNE, Bo, op. cit.

50 BROWN, Jonathan, op cit, p. 71. 
Há, por outro lado, certos aspectos ressaltados por Jonathan Brown que não passaram desapercebidos à atenção de Picasso. Pois para construir sua interpretação, Brown, como dissemos, recorre à descrição de um acontecimento que só é verossímil se aceitarmos como evidências três observações a respeito da "aparência" da pintura, deduzidas dos gestos e olhares das figuras: a sensação de movimento paralisado, sua instantaneidade e o efeito de suspensão temporal. E se para Picasso a epifania real como acontecimento preciso parece não ter qualquer relevância, o efeito de suspensão temporal, por sua vez, bem como a a sensação de movimento paralisado e de instantaneidade - isto é, as evidências que, segundo Brown, subjazem ao acontecimento central da pintura, uma súbita interrupção - são motivo de obstinado interesse. Vejamos como isso acontece.

Ao invés de ir direto ao ponto, entretanto, sugiro que comecemos pelas beiradas. Em que consistem, exatamente, o efeito de suspensão temporal, a instantaneidade e a sensação de movimento paralisado? De certa forma, trata-se de um traço constante em grande parte da obra de Velázquez. Podemos reconhecê-los em algumas de suas pinturas de gênero, e, sobretudo nos esplêndidos bodegones ${ }^{51}$ realizados no início de sua trajetória - cenas prosaicas de uma Andaluzia rural, que expressam em tons terrosos a atenção acurada por uma vida distante das regalias cortesanas que regravam o dia a dia do mundo palaciano. Nessas pinturas, o estado de suspensão temporal é logrado através de uma conjunção precisa entre a natureza morta, o gesto e os olhares das figuras retratadas ${ }^{52}$. Elas se encontram em meio a atividades corriqueiras como as de cozinhar ou comer (fig. II). Diversas vezes, direcionam o olhar ao exterior da tela e esboçam gestos em suspenso, como se tivessem paralisados em um preciso instante do decorrer dessa atividade. Elas têm dimensão humana, e são frequentemente retratadas através do recurso das mezzefigure, isto é, da cintura para cima numa relação de proximidade com o espectador.

51 A etimologia do termo bodegón foi mapeada por estudos recentes que se interessam pela pintura de natureza morta na Espanha. Um levantamento preciso pode ser consultado em: DAVIES, David. "Velázquez's bodegones", em Velázquez in Seville, pp. 51-65.

52 Tomo a questão das viariações de cenas de cozinha na obra de Velázquez a partir da perspectiva discutida em MCKIM-SMITH, Gridley; FIEDLER, Inge; MACBETH, Rhona; NEWMAN, Richard e ZUCCARI, Frank. "Velázquez: Painting from Life", Metropolitan Museum Journal, Vol. 40, Essays in Memory of John M. Brealey (2005), pp. 79-91. 
Svetlana Alpers alude a essas pinturas para defender que o olhar lancinante dessas figuras para além dos limites da tela- uma constante nos quadros de Velázquez - não inicia ou tampouco atende a qualquer acontecimento preciso, mas interpela o observador, reiterando que este reconhece a situação de ser visto, extrapolando a barreira imperceptível entre o espaço fictício da pintura e o espaço ocupado pelo espectador ${ }^{53}$. Nos bodegones, a escala, o movimento em suspenso e o apelo "realista" das figuras retratadas só viriam a comungá-lo, dando ênfase antes à "assertividade de uma presença humana sentida ${ }^{54}$ " do que a determinado fato narrativo a ser representado. De forma que, para Alpers, o efeito de suspensão temporal nessas pinturas está intimamente ligado à suspensão de uma ação narrativa. No caso específico de Las Meninas, esse mesmo efeito seria indicativo de uma ambivalência estrutural que, de forma paradoxal, permeia toda a economia da pintura: por um lado, ela opera sob a égide de um paradigma descritivo e, de outra parte, se assenta sob os preceitos da representação clássica, isto é, do modelo albertiano de perspectiva.

É curioso que o mesmo efeito de suspensão temporal seja, para Brown, evidência a partir da qual se deduz um acontecimento, ao passo que para Alpers, está associado à suspensão mesma de qualquer ação narrativa. Não se pode negar, contudo, que há uma diferença entre a gramática de gestos suspensos, postura e olhares lançados ao espectador nos bodegones de Velázquez (pinturas de dimensão mundana, que retratam um mundo prosaico) e em uma pintura de corte como Las Meninas. ${ }^{55}$

Tenhamos em vista, por exemplo, a interpretação de Victor Stoichita de um dos bodegones de Velázquez, o célebre Cristo na Casa de Marta e Maria (fig.I2). Para o autor, como para Alpers, o gesto e o olhar das figuras nessa pintura constituem, sem dúvida, um apelo ao espetador. Segundo Stoichita, no entanto, eles remetem a uma forma de organizar o quadro à maneira de um diálogo entre o observador e a imagem observada.

53 Cf. ALPERS, Svetlana. "Interpretation without Representation, or, the Viewing of Las Meninas", in Representations, No. 1 (Feb., 1983), p. 32. Considere-se, por exemplo, a asserção: "The gaze out of the canvas is a consistent feature in Velazquez's works [...]. I refer to this phenomenon as a gaze, to distinguish it from a glance. It does not initiate or attend to some occurrence; empty of expression, it is not, in short, narrative in nature. The gaze, rather, signals from within the picture that the viewer outside the picture is seen and in turn it acknowledges the state of being seen".

54 A questão do olhar como signo da "assertividade de uma presença humana sentida" na obra de Velázquez (e outros) é desenvolvida de maneira mais detida por Alpers em: ALPERS, Svetlana. "Describe or Narrate? A problem in realistic representation", in New Literary History, Vol. 8, No. 1, Readers and Spectators: Some Views and Reviews (Autumn, 1976), pp. 15-41.

55 Cf. STOICHITA, Victor. L'Instauration du Tableau. Paris: Librerie Droz, 1999, pp. 27, 28. 
Um diálogo direto, que espelha-se em figuras retóricas de discurso - a exemplo do movimento da figura à esquerda, que cumpre a função de um exhortatio. Daí a disposição das personagens em mezze-figure, daí a sensação de suspensão temporal que advém dos gestos entrecortados, ambos recursos que eliminam o distanciamento entre o espectador e o quadro $^{56}$. O pintor mais conhecido por utilizar-se desses recursos para produzir imagens de forte apelo ao espectador foi Caravaggio - em sua época, um infame "destruidor da pintura", "incapaz de narrar uma istoria", o pintor que havia, definitivamente, eliminado as mediações do "era uma vez ${ }^{57}$ " para estabeler entre espectador e obra um contato direto.

De certa forma, a leitura de Stoichita nos leva a uma asserção que, surpreendentemente, tange a formulação de Alpers, resguardadas as diferenças, é claro. Pois para o autor, nos bodegones de Velázquez (e naquele caso, em específico) o efeito de suspensão temporal está também associado a uma espécie de suspensão narrativa ${ }^{58}$, ou, ao menos, de uma narrativa em "terceira pessoa". Mas isso em se tratando de um bodegón - gênero que, tal como a pintura em mezze-figure, era, no tempo de Velázquez, considerado pela Academia como inferior e mesmo vulgar, e no qual permite-se, sem escrúpulos, que se dirija transgressivamente ao espectador. De maneira que nessas pinturas, a experiência de implicação por parte do espectador só poderia ser distinta daquela que opera em Las Meninas. Esta, evidentemente, não integra nem a classe dos bodegones e nem é uma pintura de história. Mas a que gênero, então, pertence Las Meninas? Trata-se de um retrato da infanta? De um retrato real? Voltamos à pergunta inicial, que até hoje paira como uma dúvida que não admite resposta unívoca ${ }^{59}$.

A única certeza quanto a isso é a de que, seja como for, Las Meninas é também uma pintura de corte. E que, por isso mesmo, não deixa de estar adstrita, direta ou indiretamente, a uma série de protocolos e regras de composição que têm entre seus efeitos a mediação da relação entre o observador e a obra. Não à toa, o efeito de suspensão

56 Idem.

57 A respeito da contenda entre Caravaggio e Nicolas Poussin e da ideia recorrente de que Caravaggio teria "destruído a pintura" por eliminar as mediações do "era uma vez", cf. MARIN, Louis. Détruire la Peinture. Paris: Galilée 1977.

58 Ainda que para Stoichita essa suspensão narrativa não prescinda em si da retórica como instância mediadora.

59 Sobre o gênero de Las Meninas, cf. MARÍAS, Fernando. "El género de Las Meninas: los servicios de la familia", in Otras Meninas, op. cit., p. 247-278. 


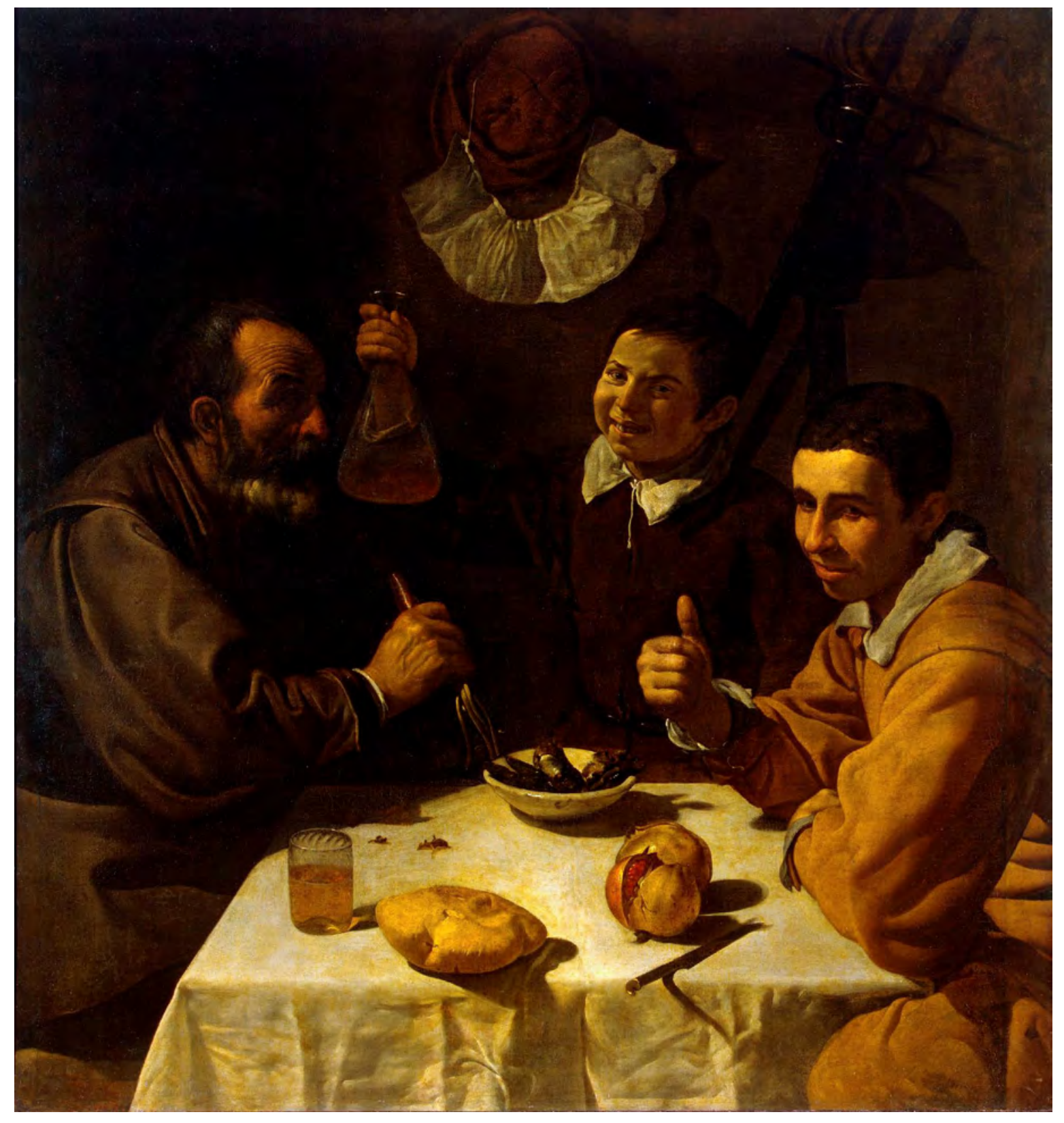

11 Diego Velázquez

O Almoço, 1617.

Óleo sobre tela.

108,5 x $102 \mathrm{~cm}$.

Museu Hermitage, São Petesburgo. 


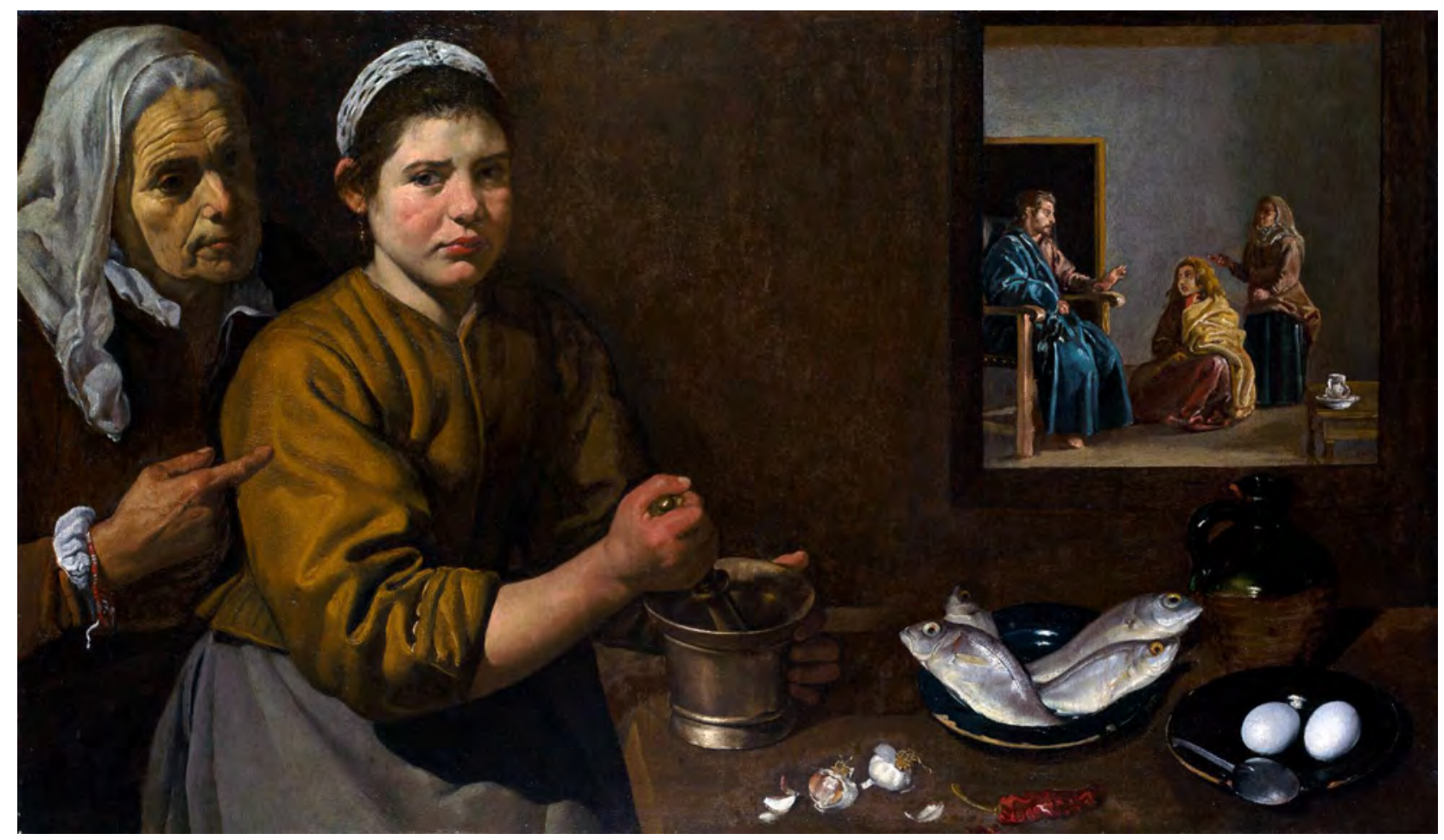

12 Diego Velázquez

Cristo na Casa de Marta e Maria, c. 1618.

Óleo sobre tela.

$60 \times 103,5 \mathrm{~cm}$.

National Gallery, Londres. 
temporal e o olhar das figuras para fora dos limites da pintura causam no espectador um estranhamento de ordem distinta daquele experienciado nas pinturas comentadas anteriormente. Ao fim e ao cabo, a sensação que se tem ao olhar Las Meninas não é somente a de estar frente à "assertividade de uma presença humana sentida ${ }^{60}$ ", mas também a de vislumbrar uma cena em que reina uma espontaneidade nada ortodoxa.

Vejamos a infanta, por exemplo: a pequena garota, em um primeiro momento, se mostra bastante dona de si ao posar para a pintura. $\mathrm{O}$ alinhamento de seu corpo rijo coincide com o eixo vertical central que corta a pintura ao meio, o que confere autoridade à pose. A iluminação incide por completo em corpo e rosto, fazendo dela a figura mais destacada do plano em que se encontra. Sua dama de companhia ajoelha-se a seu lado gesto que, a princípio, não é nada estranho à severa tradição habsburga, que prescrevia que a coreografia e o movimento do séquito deveriam cingir a órbita de imutabilidade e austeridade do monarca ${ }^{61}$. Mas então as pequenas tensões entre gestos em suspenso, pose e olhar começam, aos poucos, a revelar-se. Das nove figuras representadas, a única que efetivamente volta-se à princesa no interior do quadro é a dama de companhia ao seu lado. A rígida pose da menina - em um primeiro momento signo de sua presença elevada - de súbito começa a parecer apequenada diante da inclinação de sua aia. E a presença do anão à direita da pintura torna as dimensões da garota ainda mais diminutas.

Comparemos, por exemplo, Las Meninas (fig. I3) com uma pintura de Alonso Sánchez Coello, Dona Juana de Mendonza e um anão, datada de I585 (fig. I4). Nela, a Duquesa de Béjar, Juana de Mendonza, é retratada no ato de receber um búcaro de um anão, que, de perfil, lhe direciona um olhar diligente. A duquesa segura o objeto e olha em direção oposta à de seu súdito, conjugando o ato servil que lhe é direcionado a uma reação amena e despretensiosa e, por isso mesmo, espontânea. As escalas e proporções correspondem ao rito, e a duquesa é enobrecida.

60 ALPERS, op. cit., p.

61 Deve-se considerar que, desde a renascença, a linguagem corporal, com seu clássico antecedente nos códigos retóricos de Cícero, estava associada a visão de que os gestos estavam ligadas aos graus de civilização do sujeito. Esta relação entre linguagem corporal e civilidade foi estudada em: KNOWLSON, R. "The idea of gesture as a Universal Language in the XVIIth and XVIIIth Centuries", Journal of the History of Ideas, 26. Um estudo das normas habsburgas de etiqueta na corte espanhola pode ser consultado em MARTINEZ, Adolfo Carrasco. "Fisionomia de la virtud: Gestos, movimientos y palabras en la cultura cortesano-artistocrática del siglo XVII", Reales Sítios, 37, no. 147 (2001), pps. 26-37. 
No caso de Las Meninas, as escalas são “impertinentes ${ }^{62}$ ", para usar palavras de um tratadista do século XVII. Os olhares na pintura não expressam distanciamento: pelo contrário, são olhares atentos, de figuras que parecem precatar-se de qualquer acontecimento. Seus gestos paralisados não correspondem ao comportamento convencional da corte exibida: "Sete das nove figuras fixam o olhar para fora do quadro, se sabem observadas - mas não reagem a isso adotando uma postura apropriada para exibição ${ }^{63 "}$, nos diz Joel Snyder. A espontaneidade da cena, segundo o autor, se alcança precisamente mediante a negação de algumas convenções de espontaneidade ${ }^{64}$.

É justamente essa espontaneidade pouco convencional da pintura que levou Jonathan Brown a definir o efeito de suspensão temporal e a sensação de movimento paralisado em Las Meninas como indícios de uma interrupção da cena por "alguma outra coisa que suscede fora dos limites da pintura" ${ }^{65}$. Leo Steinberg sopesa essa possibilidade quando questiona: "Mas qual é o acontecimento? Para que estamos reunidos? "66". É o que a pintura deixa em aberto. Segundo Steinberg, não sabemos "se os cortesãos estão se reunindo conosco ou se acabamos de interrompê-los. De todo modo, o quadro figura

62 Segundo Fernando Marías, o tratadista português Félix da Costa considerou o tamanho relativo do pintor e sua posição na composição (à esquerda, por onde começamos a leitura do quadro) "impertinentes". Cf. MARÍAS, Fernando. "El género de Las Meninas: Los servícios de la família", in Otras Meninas, op. cit., p. 272.

63 Cf. SNYDER, op. cit., p. 131. Traduzido livremente do original: "seven of the nine figures stare outward, aware of being seen - but their response to being seen is not accompanied by a posture appropriate to being shown".

64 Na sociedade cortesã em que Velázquez se inscrevia, governar a si mesmo através do controle das aparências era também um indício do poder de governar o outro. O cortesão deve ser impenetrável, não deve expressar suas paixões. Os códigos e práticas de civilidade e decoro, que deveriam reger até a menor das expressões faciais, foram descritos e prescritos minuciosamente nos tratados barrocos da época. Prezava-se pelas aparências, pela impassibilidade, pela distância em nome da visibilidade. Não à toa, no século seguinte a sociedade cortesã foi duramente criticada por Rosseau sob a rúbrica de "sociedade da máscara", como império das aparências no qual não se ousa "mostrar o que se é", mas o que se exibe. Cf. ROSSEAU, Jean-Jacques. Discours sur les sciences et les arts [1750]. Paris: Garnier-Flammarion, 1971, p. 40. Interessa, a respeito desse tema, a análise do tratado L'Homme de Cour, de Balthazar Gracián, orador e jesuíta espanhol contemporâneo a Velázquez, em COURTINE, Jeans-Jacques e HAROCHE, Claudine. História do Rosto: Exprimir e calar as emoções. Petrópolis, RJ: Editora Vozes, 2016, pps. 209-233. Sobre a relação entre o pensamento de Bathazar Gracián e Velázquez, veja-se SNYDER, op. cit.

65 BROWN, op. cit., p. 70.

66 Cf. STEINBERG, Leo. "Velázquez 'Las Meninas'". October, Vol. 19 (Winter, 1981), p. 49. Traduzido livremente do original: "But what is the event? What are we party to?". 
13 Diego Velázquez

Las Meninas (Detalhe), 1656. Óleo sobre tela. 3,18 m x 2,76 m. Museu do Prado

14 Alonzo Sánchez Coello. Dona Joana de Mendoza, Duquesa de Bejar, com um anão, 1585. óleo sobre tela. Coleção Privada.
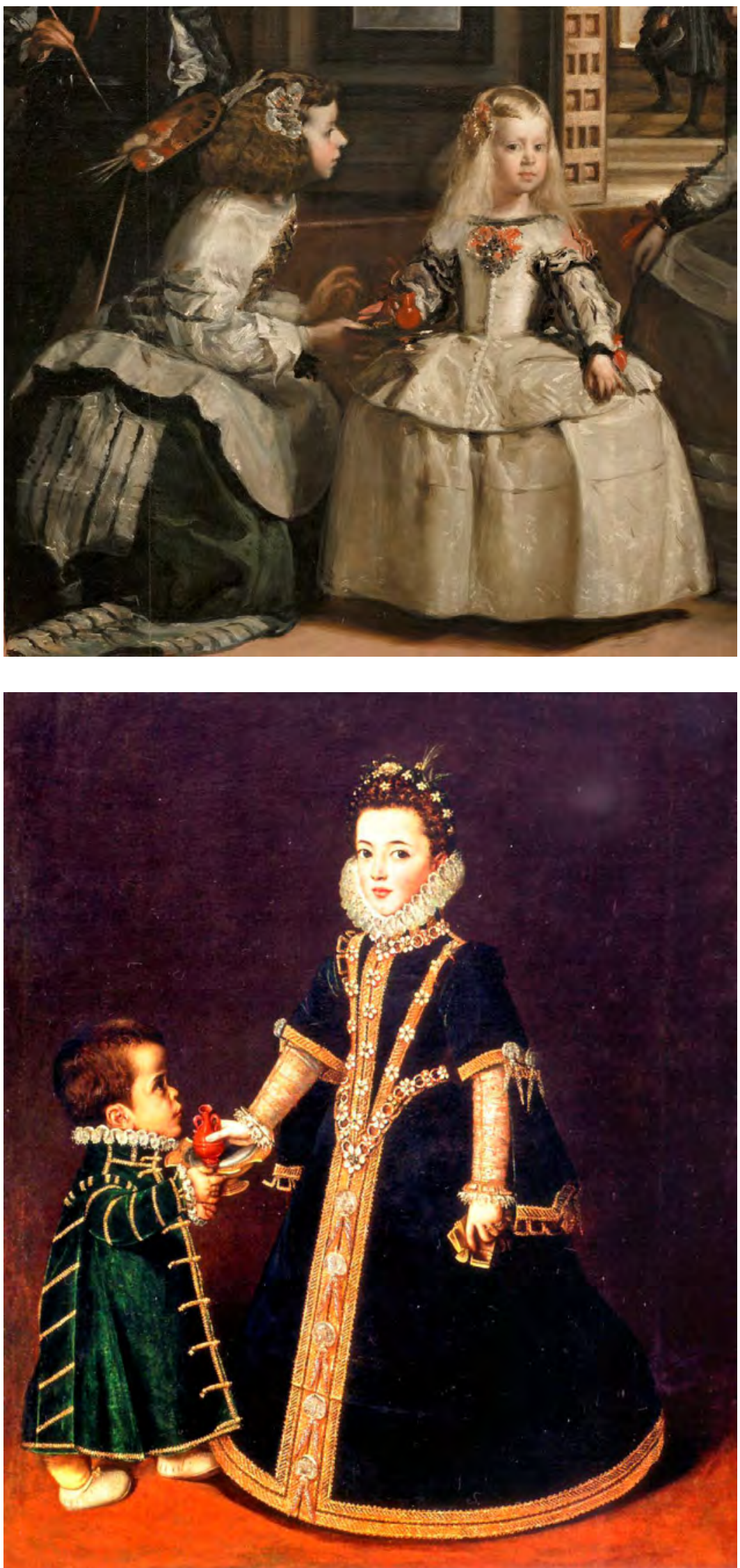
a quebra de um momento que antes deve ter sido da mais perfeita calma ${ }^{67}$. Nada diferente do que constatou Victor Stoichita: a Infanta Margarita e seu séquito - que ocupam a porção central da tela - parecem surpresos em um momento de relaxamento ${ }^{68}$.

Tudo se torna mais emblemático se considerarmos que, em meio à iminência do abalo sísmico que invade a cena, o olhar de sete das nove figuras lança-se para fora dos limites da pintura - convergindo precisamente em direção a um ponto invisível no exterior da composição. E esse ponto, ao menos à primeira vista, é precisamente o lugar en que nós mesmos estamos situados. O que produz duas consequências fundamentais: primeiramente, a infanta que num primeiro momento parece o motivo central da pintura passa a ser, simultaneamente, assunto oblíquo. E, logo, como era de se esperar: nosso olhar enquanto espectadores entra em pauta, e nos sentimos estranhamente implicados na ardilosa trama visual da composição $0^{69}$.

\section{Uma silhueta inesperada}

Quanto a Picasso, como dissemos, não parece ter-lhe passado inadvertida a tensão entre a severa rigidez da infanta e a espontaneidade pouco convencional de seus gestos, olhar e postura. Nem a capacidade que estes têm de produzir no espectador um estranhamento, sugerindo uma interrupção da cena por algo que ocorre fora de seus limites. Tampouco lhe escapa a forma como essa tensão faz da pequena princesa, paradoxalmente, motivo central e oblíquo da pintura.

Recapitulemos brevemente a toada de sua série: da primeira à sétima variação (figs. 2-8), Picasso opera cortes em sequência que redirecionam o olhar do observador, deslocando-o de uma composição do conjunto ao registro em primeiro plano dramático, como se recorresse ao recurso das mezze-figure para implicar o observador na dinâmica do quadro. Mas é precisamente a infanta (acompanhada lateralmente por sua dama de companhia) seu alvo inicial, e não só: tudo gira em torno do gesto que as une. Como se

67 ibid, p. 50. Traduzido livremente de: "He leave it as an open question wheather these courtly characters have just joined us or whether we've just walked in to interrupt them. Either way, the picture is a disturbance of what a moment before must have been perfect"

68 STOICHITA, Victor. Instauration du tableau, p. 328.

69 Não ignoro que Foucault demonstrará que o lugar de onde olhamos é também um lugar cindido, o que se depreende do próprio reflexo especular na parede. Mas isso é assunto para depois. 
esse gesto fosse em si indicativo de qualquer coisa, Picasso o isola, transformando-o em detalhe expressivo. E tudo isso é realizado através da lógica do fragmento - o que produz uma consequência fundamental: o "fora de campo", aquilo que acontece para além das margens da pintura, é imantado.

E por força magnética, a curiosidade do espectador também. Num vai e vem que nunca perde de vista os rastros daquele gesto, Picasso coordena a atenção visual desse observador, direcionando e amplificando o alcance de seu olho. Ele é instado a atentar ao contraste entre a postura rígida da garota e a suspensão de seu gesto, como se um e outro não fossem condizentes. O resultado final é um "estranhamento" que, de certo modo, remete à pintura de Velázquez: haverá passado algo fora dos limites da cena capaz de romper sua normalidade habitual?

Da oitava à décima primeira variação (figs. 8-IO), ocorre uma brusca e repentina mudança de linguagem. Picasso passa a esquadrinhar o rosto da infanta numa decomposição linear e esquemática, aplicando cores puras a traços diagramais. Aqui, é a expressão ambivalente da infanta - entre a austeridade e o espanto - o que entra em pauta. $O$ enquadramento de seu rosto é sempre o mesmo: as linhas frontais e de perfil convergem num movimento de síntese, como se transformassem a perplexidade de uma expressão facial em um sinal gráfico, na entonação inquisitiva que carrega um ponto de interrogação. Na última dessas variações, em uma pintura bastante diminuta, Picasso nos afasta novamente da visão em proximidade do rosto diagramático da princesa, deixando-nos entrever, mais uma vez, o gesto das mãos de sua dama de companhia.

É neste momento que outra mudança inesperada tem lugar. De uma linguagem sintética e esquemática, Picasso migra a uma pintura de empastes densos e expressivos, na qual cores intensas prevalecem. A décima segunda variação (fig. I5) é um retrato da infanta em que essa linguagem sobrecarregada de empastes expressivos predomina. Até aqui, a infanta se apresentava como motivo central na série: ela era a figura esquadrinhada em (ao menos) dez das doze primeiras variações. Mas é então, na décima quarta pintura (fig.16), após treze variações focadas no escrutínio de seu gesto, de sua expressão, movimento e olhar, que Picasso finalmente permite que testemunhemos aquilo que nos havia feito espreitar. De súbito, o artista abre o campo visual, permitindo-nos vislumbrar a princesa reverenciada por seu séquito. Ela é uma figura de destaque, retratada em um amarelo vibrante e destaca-se como um sol flamejante em meio aos tons de azul e verde daqueles que a rodeiam. Sua expressão é de espanto, de arrebatamento. De seu rosto e 
torso irradia mancha de cor vermelha intensa que nos conduz a uma abertura, um orifício do qual emana uma luz amarela opaca, um clarão que nos permite distinguir apenas uma silhueta negra. À contraluz, em um ponto localizado precisamente acima da figura da infanta, irrompendo de um foco nevrálgico da composição, alguém interrompe a cena.

De agora em diante, sem furtar da infanta a centralidade que outrora tivera, Picasso reparte a atenção do espectador direcionando-a àquele que, logo acima da garota, penetra no espaço pictórico e interrompe a cena. 
15 Las Meninas (infanta Margarita María). Cannes, 4 de setembro de 1957.

óleo sobre tela. 35 × $27 \mathrm{~cm}$.

Museu Picasso, Barcelona.

16 Las Meninas. Cannes, 4 de setembro de 1957. Óleo sobre tela. 35 × $27 \mathrm{~cm}$. Museu Picasso, Barcelona.
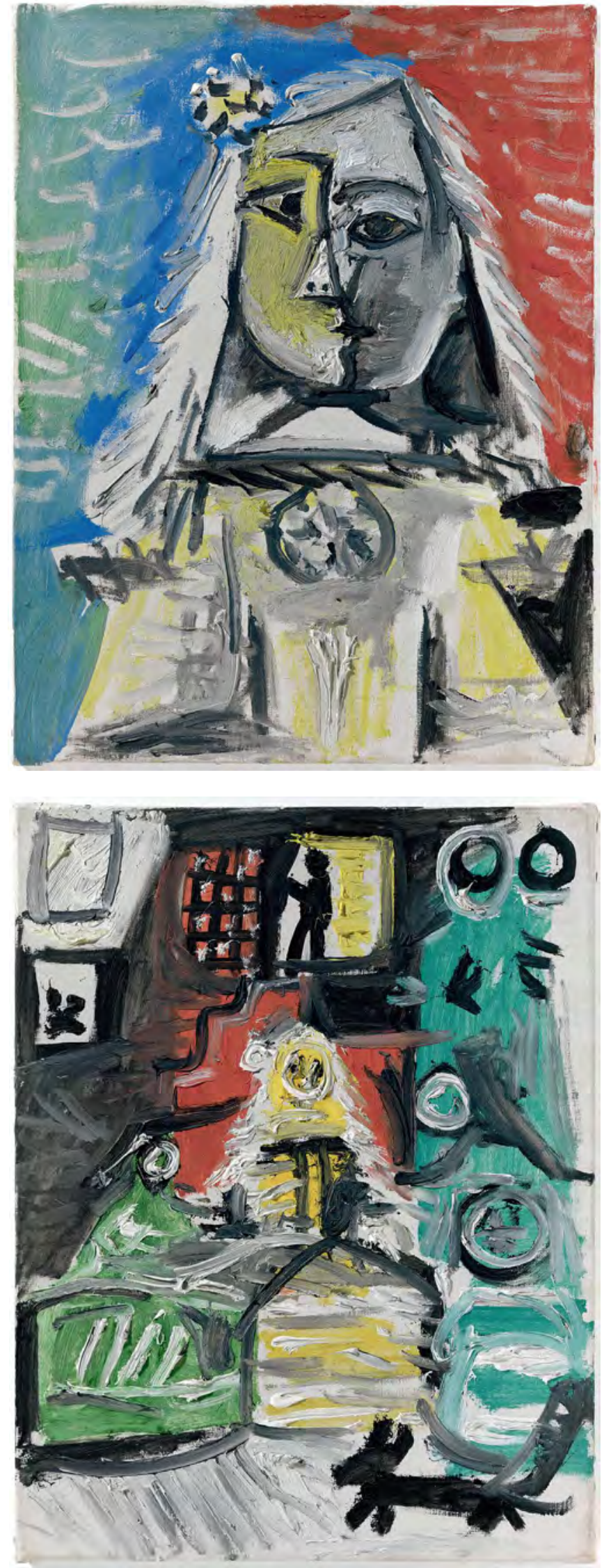
Antes de seguir, retenhamo-nos só mais um instante. Se Picasso explora, através de uma analítica exacerbada, o equilíbrio instável entre imutabilidade e espontaneidade, implicação e distanciamento, entre tema central e assuntos periféricos - que nada mais são, como a discussão da fortuna crítica nos mostra, do que parte de uma ambivalência estrutural que permeia toda a economia da pintura de Velázquez - para extrair-lhes a capacidade de sugerir uma interrupção, ele o faz de uma maneira bastante específica.

De início, opta por romper a unidade espaço-temporal da pintura original para transformá-la em uma série. Esse gesto é, por si, significativo: romper a unidade de uma pintura como Las Meninas é uma escolha determinante, não só porque indica uma forma específica de aproximar-se da pintura, mas porque faz com que nós, observadores, adotemos uma postura distinta para observá-la. As pinturas formam - quer se queira, quer não - uma sequência composta de fragmentos em decurso. Não à toa, como dissemos, suas variações são diligentemente datadas, uma a uma, e doadas em sua totalidade, conforme o desejo do próprio artísta, ao Museu Picasso Barcelona. Vistas em continuidade, essas pinturas apresentam-se como uma sucessão de cortes segundo uma variação sutil de ângulos, uma coleção de pontos de vista de um mesmo fato, ou, neste caso, de uma única pintura. É como se Picasso rondasse a infanta e sua dama de companhia num vai-e-vem afastando-se e aproximando-se, recolhendo cortes aqui e ali para colocá-los em cadeia, procedendo quase que conforme a lógica de uma decupagem fílmica.

A palavra, derivada do francês, está associada a um vocabulário cinematográfico, e, em linhas resumidas, designa o processo de decomposição de uma ação em planos que correspondem a fatias de espaço e fatias de tempo ${ }^{70}$. Ao observar as pinturas lado a lado saltamos de um ponto a outro, e (por que não?) de um instante a outro.

Não que a operação de Picasso transpareça qualquer apelo à ficção, como em geral há no cinema. Mas a lógica de fixação de um instante através da multiplicação de detalhes que se desdobram linear e intercaladamente produz uma sensação de duração prolongada, uma duração distendida que nos faz transitar do domínio da espacialidade para o da temporalidade. Se a tela de Velázquez coordenava na geometria perspectiva uma unidade

70 Há uma vasta bibliografia a respeito da noção de decupagem. Empresto aqui a definição de Noel Burch, que a formula, do ponto de vista formal, como síntese e convergência entre fatias de tempo e fatias de espaço. Cf. BURCH, Noel. Práxis do Cinema, trad. Marcelle Pithon e Regina Machado. São Paulo: Ed. Perspectiva, 1992, pp. 21-53. 
espaço-temporal, as variações de Picasso parecem promover uma (des)continuidade espaçotemporal reconstruída ${ }^{71}$. Passamos a ver em sequência o que antes era simultâneo.

Nessa empreitada, são diversos os elementos que remetem à linguagem cinemateográfica. Da primeira à segunda variação (fig. 2-3), por exemplo, Picasso opera um movimento que se assemelha ao de um corte em plano que, não em vão, põe em evidência as mãos absortas da pequena infanta segurando o búcaro oferecido por sua dama de companhia. Do conjunto ao detalhe expressivo, o artista direciona e coordena a atenção visual em um nódulo específico, a partir do qual as próximas pinturas se desdobrarão. A segunda e a terceira variações (fig. 3-4) funcionam como uma espécie, ainda que não a rigor, de campo/contracampo: elas opõem a infanta e sua aia (antes situadas em segmentos adjacentes da cena) em planos intercalados e complementares. O elemento que as une em faces opostas de um mesmo eixo é, justamente, o movimento de suas mãos.

Ato contínuo, Picasso nos coloca diante de outro corte que, desta vez, opera como um close-up (figs. 5-6). Nos a proximamos do rosto da infanta, que tem uma expressão vacilante, interrogativa. Em seguida, nos afasta novamente da garota, retornando à imagem de seu corpo inteiro no momento em que segura o búcaro. Outra vez, o ritmo imposto nos repõe insistentemente a esse mesmo instante, como se por trás desse gesto assignificante se ocultasse, precisamente, algo invisível. Através do engajamento de um olhar perscrutador, somos induzidos (ou conduzidos) a examinar os movimentos e a postura da infanta, interrogando a gramática disruptiva que os articula. Suspeitamos - ou somos levados a suspeitar - que qualquer coisa irrompeu no universo inocente em que a menina se encontrava, deflagrando-a em movimentos desarticulados. Somos encorajados, como em certos filmes de trama detetivesca, a conjecturar sobre as lacunas do que nos é apresentado, como se estivéssemos envolvidos numa espécie de intriga visual ${ }^{72}$.

71 Tomo a ideia de continuidade espaço-temporal reconstruída da discussão de Ismail Xavier sobre decupagem clássica. Para o autor, "As famosas regras de continuidade funcionam justamente para estabelecer uma combinação de planos de modo que resulte uma sequência fluente de imagens, tendente a dissolver a 'descontinuidade visual elementar' numa continuidade espaço-temporal reconstruída." Cf. XAVIER, Ismail. O discurso cinematográfico: a opacidade e a transparência, 3a edição. São Paulo, Paz e Terra, 2005, p. 32. Como no caso de Picasso não há qualquer intenção narrativa que busque extrair o rendimento dos efeitos de decupagem e montagem para torná-las invisíveis em favor da manutenção da integridade e fluência do fato representado, prefiro à palavra continuidade a noção de descontinuidade, que parece melhor descrever a duração e a temporalidade no trabalho de Picasso.

72 Tomo o conceito de intriga visual tal como formulado por STOICHITA, Victor. L'effet Sherlock Holmes. Paris: Hazan, 2015. 


\section{Picasso/TV?}

Talvez a aproximação entre Las Meninas e a linguagem cinematográfica pareça, em um primeiro momento, fora de lugar. Não estaria o universo do cinema a léguas de distância de Picasso, o artista moderno por excelência, conhecido por desprezar até mesmo a fotografia ${ }^{73}$; aquele que, como relatou Fernande Olivier, sucumbira certa vez, quando jovem, ao paroxismo de uma crise nervosa provocada pelo consumo de haxixe, esbravejando uma reação fóbica à mecanização da visão: "descobri a fotografia, eu deveria me matar, não tenho mais nada a aprender"74?

E quanto a Las Meninas, não seriam elas o testemunho da criatividade mercurial desse Picasso, dedicado agora, aos setenta e seis anos, a reavivar as formas do passado para medir-se lado a lado com os seus mestres no panteão da pintura ocidental75? A depender dele próprio e de suas afirmações amiúde contraditórias, certamente. Sabartès lembra que, alguns anos antes de realizar sua própria versão de Las Meninas, Picasso havia dito:

Suponhamos que alguém fosse fazer, de boa fé, uma cópia de Las Meninas; chegaria o momento, caso este que copiasse fosse eu, em que diria a mim mesmo: e se eu movesse essa figura um pouquinho para a direita ou para a esquerda? Eu tentaria fazê-lo à minha maneira, esquecendo Velázquez. Certamente, a tentativa me levaria a alterar e modificar a luz, tendo em vista a posição alterada daquela personagem.

73 O pressuposto de que Picasso desprezava a fotografia, a não ser como modo de documentar seu próprio trabalho, tem sido adotado por seus estudiosos há muito tempo. Cabe assinalar, no entanto, que a presumida hostilidade de Picasso em relação à fotografia tem sido alvo de revisão por estudiosos ao longo das últimas décadas. As investigações levadas a cabo no vasto arquivo pessoal do artista têm demonstrado que ele não só utilizava fotografias próprias como modelo para suas pinturas, mas que também um vasto repertório de cartões postais e fotografia estereoscópica alimentava sua criatividade. Cf. BALDESSARI, Anne. Picasso and Photography: The Dark Mirror. Houston: The Museum of Fine Arts, 1997.

74 O episódio foi relatado muitos anos depois por: OLIVIER, Fernande. Picasso and His Friends, trad. J. Miller, New York, 1965, 133-134. C

75 Veja-se GALASSI, Susan Grace. Picasso's Variations on the Masters: Confrontations with the Past. Nova lorque: Harry N. Abrams, 1996; COOPER, Douglas David. Pablo Picasso: Les Déjeneurs. Paris: Éditions Cercle d'Art, 1962. BERNADAC, Marie-Laure. "Picasso Cannibale. DesconstructionReconstruction des Mâires, em Picasso et les Mâitres, Anne Baldessari e Marie-Laure Bernardac (orgs.). Paris: Éditions de la Réunion des Musées Nationaux, 2008, pp. 36-52. 
Assim, pouco a pouco, eu criaria umas Meninas que pareceriam detestáveis ao copista de ofício. Não seriam as meninas que ele viu quando olhou a pintura de Velázquez; seriam as minhas meninas. ${ }^{76}$

Mas espere. Estaria realmente Picasso, um dos mais renomados artistas do século, se comparando com um copista de ofício? Ou essa é apenas uma autoadulação retórica? Se pudéssemos descrever a operação reivindicada nessa fala, diríamos: Picasso, "criador e destruidor ${ }^{77}$, não reproduz uma pintura antiga, mas a reinventa. Ao debruçarse sobre determinado tema, institui sutis variações de luz, de composição, de cor, etc., aplicando sua maestria até modifica-lo e transformá-lo em uma interpretação singular. Nada distinto da maneira como grandes artistas se apropriaram do trabalho de antigos mestres ao longo da vasta história da pintura ocidental ${ }^{78}$.

76 SABARTÉS, Jaimes, op. cit. p. 7 .Traduzido pela autora da dissertação, do original em espanhol: "Si uno se pusiera a copiar Las Meninas, de toda buena fe, pongamos por caso, al llegar a certo punto y si el que copiasse fuera yo, me diría: que tal poner a ésa un poquitín más a la derecha o a la izquierda? Y probaría a hacerlo a mí manera, olvidando a Velázquez. La prueba me llevaría de seguro a modificar la luz o a cambiarla, con motivo de haber cambiado de lugar a un personaje. Así, poquito a poquito, iria pintando unas Meninas que pareceria detestables al copista de ofício; no serían las que él creería haber visto en la tela de Velázquez, pero serían mis Meninas.".

77 Tomo emprestado o oxímoro presente no títuto do "romance de folhetim" de Arianna Huffington. Em uma biografia sobre Picasso, a autora se refere a um regime dicotômico que estaria vinculado tanto ao processo criativo do artista quanto à sua relação com as pessoas (e em especial, asmulheres) - adicionando ao título "Picasso créateur", cunhado por Pierre Daix, o antônimo de destruidor. Cabe ressaltar, de todo modo, que a ideia de um Picasso iconoclasta era sustentada pelo próprio artista, que é conhecido por sua frase: "Antes, um quadro era uma soma de adições. Comigo, é uma soma de destruições". Cf. HUFFINGTON, Arianna. Picasso: Criador e Destruidor, São Paulo: Editora Best Seller, 1984.

78 Consideremos as inúmeras apropriações de Masaccio por Michelangelo, de Mantegna por Dürer, de Michelangelo por Rubens, de Rafael por Poussin, de Paolo Uccello por Degas, de Delacroix por Matisse, apenas para elencar os casos mais conhecidos. Sobre a prática de variações na história da arte, ver: MAISON, K. E. Themes and Variations: Five Centuries of Master Copies and Interpretations. Londres e Nova lorque: Harry N. Abrams, 1960; HAVERKRAMP BEGEMANN, Egbert e LOGAN, Carolyn. Creative Copies: Interpretative Drawings from Michelangelo to Picasso. Nova lorque: The Drawing Center, 1988. A respeito da prática da cópia na arte moderna, veja-se: BENJAMIN, Roger. Recovering authors: the modern copy, copy exhibitions and Matisse. (Art History, vol. 12 no. 2, junho de 1989, pp. 177-201. Cabe destacar que, muitos assuntos que tangem a prática de variações, tais as questões relativas à representação, apropriação, repetição, influência, original e cópia, autoria, etc., tem sido bastante debatidas na esfera mais ampla da cultura sob distintos enfoques e perspectivas. Cito as reflexões de KRAUSS, Rosalind, "Originality as Repetition: Introduction", October vol. 37, 1986, pps. 35- 40, (Incluidos nesse volume estão também outros artigos relativos a um simpósio organizado em 1985 por Krauss e intitulado "Multiples without Originals: The Challenge to Art History 
O caso das apropriações que Goya faz de certas ilustrações de John Flaxman sobre O Inferno de Dante elucida bem o tipo de prática que Picasso reivindica para si. De início, Goya se propõe a estudar pacientemente as gravuras de Flaxman, focalizando múltiplos aspectos: as soluções compositivas, aglomerações de figuras, a distorção e redução dos corpos, os gestos, entre outras características. Alguns de seus desenhos são quase cópias do artista inglês no sentido corriqueiro da palavra. Em outros desenhos, o espanhol apropria-se de motivos, fragmentos ou características específicas de diferentes gravuras de Flaxman para fundi-los de forma inusitada. Aos poucos, a referencialidade explícita é diluída, o que não exclui o fato de que grande parte das pranchas do famoso álbum Os Desastres da Guerra ${ }^{79}$, de Goya, reverberam o eco longínquo de Flaxman. Mas agora o traço já não é linear e sintético como antes - há um desenho particular, bem como uma sofisticada relação de contrastes outrora inexistentes. De modo que quem observa, por exemplo, o Caminho do Inferno de Goya não mais se vê diante de O Inferno de Flaxman, mas de um legítimo Goya que qualquer expertise reconheceria. E assim, a arte renova-se a partir de sua própria tradição, sem que nada se deva às noções de estilo e individualidade que subjazem a lógica da criação.

Isso não é exatamente o que ocorre no caso de Picasso. Suas variações, embora carreguem signos de singularidade, não obedecem exatamente à lógica rigorosa da imposição de maestria ou habilidade ante um determinado modelo pictórico que buscam ao mesmo tempo preservar e suplantar. Essas variações - ao menos no que concerne a Las Meninas - não são "composições" (no sentido herdado da tradição da pintura) derivadas de outras, e nem tampouco estudos para composições propriamente ditas. Cada uma delas estará sempre assombrada pelo fantasma da designação d'aprés Velázquez. E não por que sejam menores, mas porque sua lógica não é a da substituição, ainda que parcial, mas a da metonímia. Cada unidade de Las Meninas de Picasso está sempre em relação ao quadro de Velázquez do mesmo modo como mantém, via de regra, uma relação estreita com a variação anterior e com a seguinte. Não há qualquer pintura que se sobressaia, que seja ela própria o resultado de uma bateria de esboços e estudos preparatórios.

of the 'Copy'"); Jean BAUDRILLARD, Simulacros e Simulação. Lisboa: Relógio d'Água, 1991; Michael FOUCAULT. O Que é um Autor. Lisboa: Vega, 2002; SCHIFF, Richard. "Representation, Copying and the Technique of Originality, New Literary History, vol 15, no. 2, 1984, pp. 333-63.

79 A respeito da apropriação de Flaxman por Goya, veja-se: SYMMONS, Sarah. "John Flaxman and Francisco Goya: Infernos Transcribed", The Burlington Magazine, Vol. 113, No. 822 (Sep., 1971), pp. 506-512. 
De maneira semelhante, um plano de um filme pode ser visto em sua singularidade, mas ele estará sempre para o conjunto como uma unidade está para o todo.

De certa forma, a aproximação entre as variações de Picasso e a lógica da decupagem técnica remonta à intepretação que Rosalind Krauss fornece dos sketchbooks realizados por Picasso a partir de Le Déjeneur sur l'herbe, de Manet (figs. I7-I9), em I96I ${ }^{80}$, comentada brevemente na introdução. Segundo a autora, não é somente como se Picasso, através de sua prática de variações dos antigos mestres, buscasse modelos na grande tradição da pintura para emprestar do repertório da história da arte aquilo que a vida não mais lhe trazia de inspiração. Ele estaria, ainda, de forma reativa, deixando apropriar-se pelo universo da reprodução mecânica e da cultura de massas, da qual a arte moderna nunca esteve livre. Picasso, num martelar incansável, preencheu cadernos e cadernos com um sem fim de variações- dez, quinze, dezoito podiam ser realizadas em um único dia - num movimento obsessivo que não obedece à lógica do surgimento de inspiração renovada, que, conforme sinalizamos e segundo a própria autora, é frequentemente evocada pela fortuna crítica ao comentar esses trabalhos. Para Krauss, o movimento frenético dos scketchbooks de Picasso responde, antes, a um processo mecânico de repetição voluntária, de controle espontâneo da diferença. É como se, através da análise do gesto serial, Picasso criasse variações sequenciais mínimas acionadas pelo movimento de páginas de um flipbook. Cada uma das variações - também diligentemente numeradas e data$\mathrm{das}^{8 \mathrm{I}}$ - funciona como um centésimo de segundo de um cartoon animado. Traçando uma surpreendente relação entre o trabalho de artistas frequentemente acomodados sob a rúbrica de linhagens opostas da arte moderna (como Duchamp, Max Ernst, Giacometti

80 KRAUSS, Rosalind. "The im/pulse to see", in Vision and Visuality: Discussions in contemporary culture, ed. Hal Foster. Washington, DIA Foundation, 1988, pp. 51-79.

Krauss utiliza-se de argumentos psicanalíticos, de Lacan a Derrida, para o sustento de seu argumento. Segundo ela, no caso de Picasso, trata-se de um mecanismo inconsciente de reação ao universo mecânico da cultura de massas. Alguns anos mais tarde, a autora desenvolverá o argumento no quinto capítulo de seu livro sobre o inconsciente óptico, relacionando-o com o conceito que ela mesma propõe e com as teorias de Bergson sobre o instante. Cf. KRAUSS, Rosalind. "The Optical Unconsciouss", Cambridge: MIT Press, 1994, pp. 197-243. Em outra ocasião, a autora já havia defendido que a repetição e o pastiche na obra de Picasso irrompem como uma forma de reação. Veja-se KRAUSS, 2001, op. cit., p. 75-205.

81 Picasso, desde os anos de 1930, numerava e datava seus trabalhos. Para um comentário crítico sobre esse mecanismo e sua relação com a criação de uma imagem, veja-se "Different Picassos", em GREEN, Christopher. Picasso, Architecture and Vertigo. New Haven e Londres: Yale University Press, 2005. 

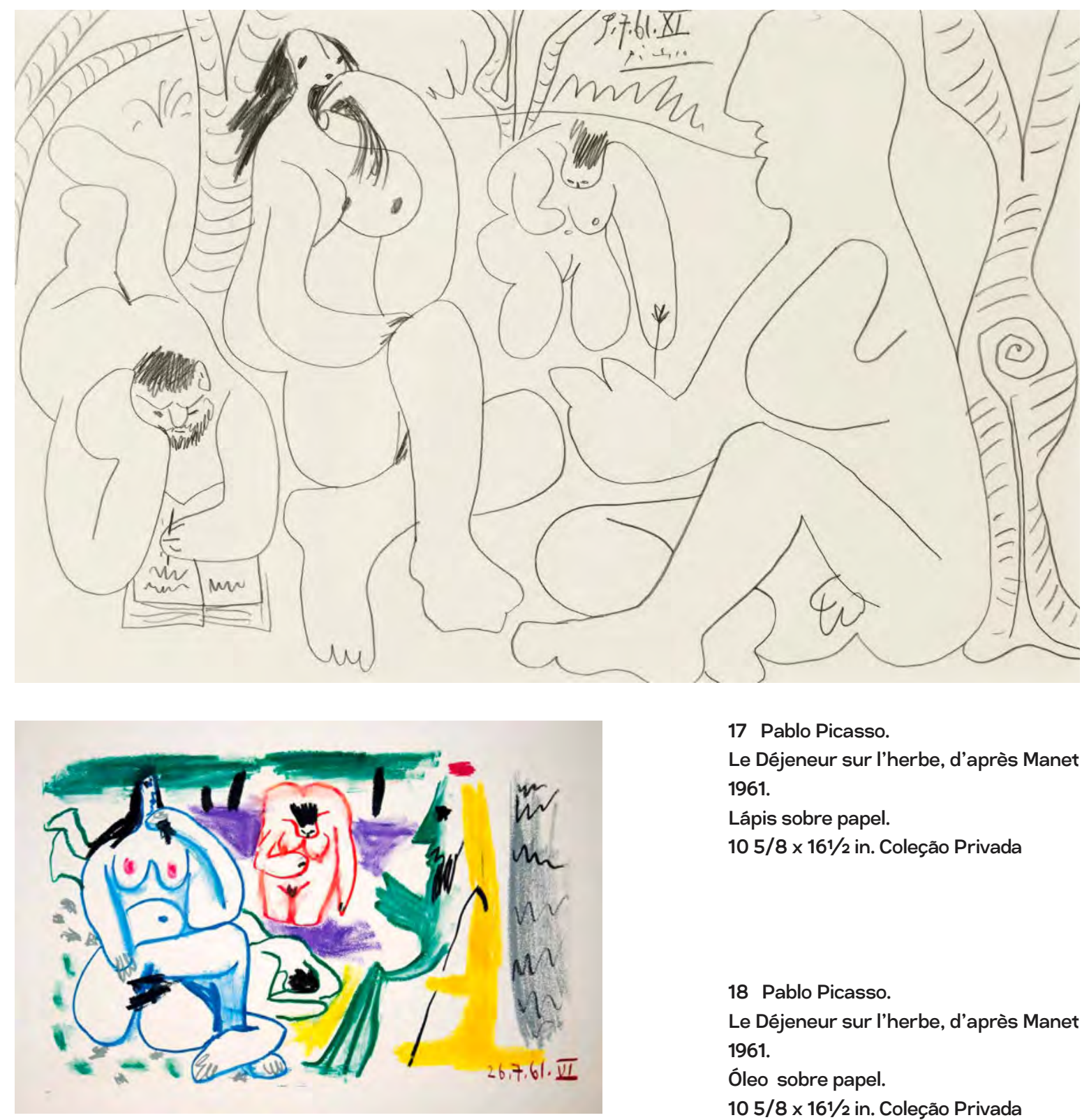

17 Pablo Picasso.

Le Déjeneur sur l'herbe, d'après Manet 1961.

Lápis sobre papel.

10 5/8 x 161/2 in. Coleção Privada

18 Pablo Picasso.

Le Déjeneur sur l'herbe, d'après Manet 1961.

Óleo sobre papel.

10 5/8 x 161/2 in. Coleção Privada

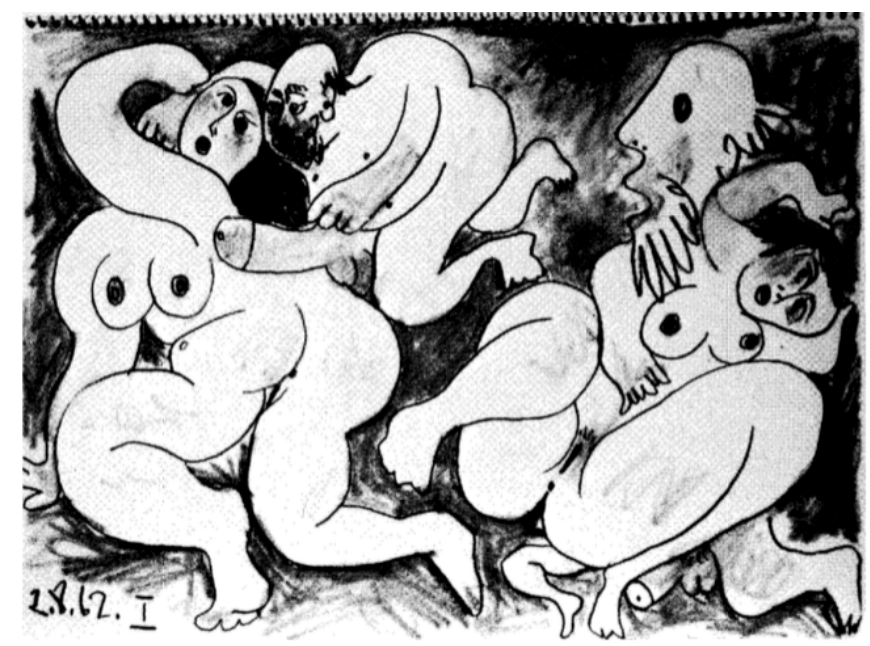

19 Pablo Picasso.

Le Déjeneur sur l'herbe, d'après Manet 1962.

Lápis sobre folha de caderno.

10 5/8 x 161/2 in. Coleção Privada 
e Picasso), Krauss estabelece parâmetros para refletir sobre as maneiras como a arte incorpora o ritmo, a pulsão, o movimento e a dimensão temporal da repetição que, em última instância, remontam a formas de espetáculo e dispositivos ópticos do século XIX (estereoscópios, zootropos, praxinoscópios, lanternas mágicas, etc) $)^{82}$.

É evidente que algo do universo da animação ecoa também nas variações Las Meninas e repercute em cada uma das pinturas da série. A expressão das figuras é amiúde marcada pelo traço cortante de um humor ácido, quando não caricaturesco ${ }^{83}$. Ao comentar a série, um estudioso chegou a converter o ambiente das pinturas no cenário artificial de uma "casa de bonecas", enfatizando não só a expressividade à maneira cartoon ["the cartoon expressiveness"] das figuras, mas também o uso de cores puras e o emprego da técnica infantil do crayon ["the childlike crayon technique"]

Não que a lógica de variações em Las Meninas obedeça ao mesmo ritmo frenético ou padrão de animação de um scketchbook, como acontece em Le Déjeneur sur l'Herbe - quando os desenhos, como descreve Krauss, se desdobram em um processo contínuo que faz com que os corpos representados mudem gradualmente de posição até atingir seu apogeu (isto é, o mais explícito e caloroso copular). Na série inspirada por Velázquez, as pinturas não formam uma única sequência que se estende em sua linearidade, mas um conjunto ramificado em diversas sequências, cada qual com traços estilísticos particulares. Curiosamente, a tão celebrada (ou famigerada, conforme se veja) capacidade de Picasso de transitar pelos mais variados estilos parece, aqui, cumprir um padrão sequencial. E o que importa, em cada uma das sequências, não é a duração ou extensão ou graduação de seu movimento, mas

82 KRAUSS, 1988, op. cit., p. 55-58. Cabe salientar que em sua análise, Krauss tem em vista a mudança de paradigma na ciência da visão que Jonathan Crary localiza no século XIX. Cf. CRARY, Jonathan. Técnicas do Observador: Visão e Modernidade no Século XIX. São Paulo, Contraponto, 2015.

83 Para a relação entre Picasso e a caricatura vide: HUTTON TURNER, Elisabeth. "Who Is in the Brothel of Avignon? A Case for Context". Artibus et Historiae, Vol. 5, No. 9 (1984), pp. 139-157; GOPNIK, Adam. "High and Low: Caricature, Primitivism, and the Cubist Portrait". Art Journal, Vol. 43, No. 4, The Issue of Caricature (Winter, 1983), pp. 371-376.

Peter Egri chega a sugerir que o universo da caricatura está presente de forma mais contundente na idade madura de Picasso, e sobretudo nas séries de variações que faz dos grandes mestres. Vide: EGRI, Peter. "A Portrait of the Artist as a Caricaturist: Picasso, Joyce, Britten", Comparative Literature Studies, Vol. 19, No. 2, James Joyce and His Contemporaries (Summer, 1982), pp. 97-120.

84 ANDERSON, John. "Faustus/ Velázquez / Picasso", in Picasso in Perspective, Gert Schiff (org.), New Jersey: Prentice-Hall, 1976, p. 161. 
a maneira como sua organização por meio de cortes é capaz de promover determinada experiência de focalização. Por isso mesmo, a analogia com a decupagem.

Picasso, como se sabe, gostava de assistir aos mais diversos filmes na televisão instalada no interior de sua residência La Californie: entre dramas, terror, suspense, comédias, faroestes, filmes sobre a antiguidade clássica, enfim, todo o conteúdo disponível nos três canais televisivos aos que se tinha acesso no sul da França ${ }^{85}$. O cinema - consumido por Picasso como uma linguagem filtrada pela natureza característica do tubo televisivo - era, na época em que o artista produziu sua série de variações de Las Meninas, uma de suas principais formas de entretenimento. O pequeno aparelho permitia que Picasso tivesse acesso a dezenas de filmes sem sair de sua sala de estar, assim como uma reprodução fotográfica em preto e branco permitia que o artista, desde o interior de sua mansão em Cannes, pudesse ver e manipular Las Meninas de Velázquez sem nem mesmo sonhar em revisitar o Museu do Prado ${ }^{86}$.

85 O fascínio de Picasso pela televisão é conhecido, foi documentado e comentado por diversos estudiosos. Considere-se, por exemplo, a recente exposição "Picasso TV", realizada no Museo Picasso Málaga, que se propôs a explorar o tema. Para o catálogo, consultar: MADELINE, Laurence (org.). Picasso TV. Málaga: Fundación Museo Picasso Málaga, 2014. John Richardson afirma que o artista e sua companheira Jacqueline Roque, durante a década de 1960, frequentemente assistiam a filmes na televisão. Em: RICHARDSON, John. "L'epoque de Jacqueline", Le Dernier Picasso, 1953-1973, Paris: Centre George Pompidou, 1988, pp. 53-77. Rosalind Krauss discorre sobre o entusiasmo de Picasso em relação às transmissões de luta livre, popularmente conhecidas como catch. Cf. : KRAUSS, Rosalind. "The Optical Unconsciouss", Cambridge: MIT Press, 1994, p. 198-201. Em um estudo sobre a série suite 347, Memory Holloway explora a relação entre Picasso e televisão, buscando influxos tanto das lutas livres quanto do cinema holywoodiano em seu trabalho. Veja-se HOLLOWAY, Memory. "Inside the Sultan's Palace: Picasso and Television", em Making Time: Picasso's Suite 347. Nova lorque: Peter Lang Publisher, American university studies XX. Fine arts, vol. 35, pp. 123 - 139. Outra aproximação que põe em pauta a relação entre as gravuras da maturidade de Picasso e a imagem em movimento foi realizada por BARAÑANO, Kosme de. "La Suite 156 de Pablo Picasso como Screenplay y Script.", in Picasso: Cine y Arte. Málaga: Fundación Picasso Museo Casa Natal, 2011, pp. 65 - 117.

86 Picasso, conforme relata Sabartés, trabalhou a partir de uma reprodução fotográfica em branco e preto da pintura de Velázquez. Cf. SABARTÉS, Jaime. Picasso: Las Meninas y la Vida. Barcelona, Ediciones Poligrafa, 1969, p. 19. A última vez que Picasso deve ter visto Las Meninas foi durante uma viagem a Madri em 1934. Depois disso, quando foi diretor nomeado do Museu do Prado, entre 1936 e 1939, pode ter tido contato com a obra, uma vez que em 1938 parte do acervo do museu foi evacuado a Genebra por conta da Guerra Civil Espanhola. C.f. PENROSE, Roland. Op. cit., p. 497, RAFART i PLANAS, Claustre. Las Meninas de Picasso, Barcelona: Meteora, 2001, p. 27. 


\section{Uma atmosfera de suspense, um enigma sem resposta}

A essa altura, espero ter deixado claro que a analogia entre a lógica da decupagem e as operações analíticas promovidas por Picasso em Las Meninas está menos relacionada a uma dimensão de temporalidade ou duração que a série poderia ter do que a uma determinada experiência de "centralização" do olhar que o procedimento cinematográfico é capaz de promover. Afinal, por mais diligente que seja a ação de Picasso de datar e enumerar as obras hiearquizando-as cronologicamente, o observador tem a autonomia de ver e rever cada uma das pinturas quebrando qualquer padrão de duração vinculado à sequencialidade da série. Mais difícil é escapar do ritmo e condução instaurados pela dinâmica de cortes e, sobretudo, do olhar curioso e perscrutador que essa dinâmica é capaz de instigar.

Quando Picasso, nos anos de I950, produziu sua versão de Las Meninas, as imbricadas intrigas visuais de sanha detetivesca encontravam no cinema de Alfred Hitchcock a expressão mais emblemática. Seus filmes, a exemplo do célebre Janela Indiscreta (Rear Window, I954), encarnam de maneira tenaz a lógica de um olhar perscrutador, que demarca de forma precisa seu foco de atenção, de um olhar dotado da "capacidade cortante de enquadrar e de centrar, de desenhar por uma exacerbação ou uma exorbitância simbólicas um fragmento de mundo subitamente inchado por uma atenção humana ${ }^{87 "}$. Não à toa, Hitchcock maneja com maestria um movimento semelhante ao que descrevemos há pouco: da tomada geral ao plano-detalhe, "da paisagem em direção à mancha, do plano de conjunto ao primeiro plano ${ }^{88 "}$, levando ao extremo o poder de centralização instaurado pela variação de pontos de vista que proporcionam as ferramentas da decupagem técnica (como o corte em cena ou o close-up).

A invenção desses mecanismos, do ponto de vista de uma história das formas cinematográficas, remonta a um momento anterior à obra de Hitchcock, que começa por volta de $1925^{89}$. A exploração narrativa da montagem e o uso psicológico do primeiro plano, procedimentos que estariam na base do suspense hitchcockiano, podem ser encontrados

87 AUMONT, Jacques. "Le plan", in BAECQUE, Antoine de (org.), Cahiers du cinéma - Le siècle du cinéma, Hors- série, novembro de 2000, p. 38.

88 BONITZER, Pascal. "Le suspense hitchcockien", in Le champ aveugle: essais sur le cinéma, Paris: Gallimard; Cahiers du cinéma, 1982, p. 61.

89 Devo minha compreensão do procedimento de decupagem em Hitchcock às conversas com Luiz Carlos de Oliveira Jr. e à leitura de OLIVEIRA JR., Luiz Carlos. Vertigo, a teoria artística de Alfred Hitchcock e seus desdobramentos no cinema moderno. Tese (Doutorado em Meios e Processos Audiovisuais) - Escola de Comunicações e Artes, Universidade de São Paulo, São Paulo, p. 8. 
já em filmes dos anos I9IO. Antes disso, o cinema, de modo geral, contava suas histórias através de uma sucessão de tableaux, de cenas condensadas num bloco de ação registrado a partir de uma tomada geral do ambiente, de um único ponto de vista frontal e fixo. Herdeira de uma tradição de espetáculo cênico do século XIX, a estética do tableau ou do "quadro primitivo" funcionava como uma versão impressa do palco teatral. Com os procedimentos de decupagem, as cenas exibidas em bloco gradativamente passaram a se apresentar em pedaços, sinalizando uma mudança do tableau ao plano, da aglomeração de registros aos efeitos de montagem. E é justamente na obra de Hitchcock que esses procedimentos são radicalizados de modo a dirigir e centrar a atenção do espectador, produzindo a extrema excitação do exercício do olhar. Se em seus filmes a câmera percorre o espaço partindo, em muitos casos, da visão de conjunto, a sucessão de planos derivada dos mecanismos de decupagem e montagem gradativamente desloca o olhar do espectador em direção a um detalhe, a um ponto do espaço em que determinado elemento se insurge contra a normalidade reinante, inicitando a suspeita, aguçando o apetite do olho.

Conta-se que Godard, certa vez, dividiu os cineastas entre dois tipos: os que veem e os que miram. Os primeiros, segundo ele, andam com a cabeça baixa, olhando para o chão, levantando a cabeça para abarcar com várias vistas o campo que se oferece ante seus olhos. Os segundos, a exemplo emblemático de Hitchcock, não exatamente veem, mas miram: andam de cabeça erguida, fixando sua atenção nos pontos precisos que lhes interessam ${ }^{90}$.

Picasso, de certa forma, inicia suas variações "mirando" o quadro de Velázquez. Parte de uma visão geral, de um mapeamento do aglomerado de figuras que se exibe em conjunto na pintura de Velázquez - que, curiosamente, aos olhos do século XIX, parecia mais a um tableau vivant que a uma pintura ${ }^{91}$ - como se o escaneasse para encontrar um alvo a partir do qual começa a desenvolver sua série. E esse alvo, o investimento de sua "mirada", é, precisamente, o gesto que se desenrola entre a infanta e sua dama de companhia. Esse detalhe é o elo que une e encadeia as pinturas em sua intensidade dramática. De uma pintura a outra, somos levados a especular sobre esse gesto. Ele, em sua condição disjuntiva, coloca em xeque a inocência da cena, é o foco de tensão que engendra nossos investimentos especulativos.

90 Citado em OLIVEIRA JR., op. cit., p. 9.

91 Segundo Stoichita, muitos comentadores cederam a essa 'tentação'. STOICHITA, Victor. "Imago Regis: Teoría del Arte y Retrato Real en Las Meninas de Velázquez", in Otras Meninas, op. cit., p. 183. 
Mas, se em um filme de suspense e mesmo nos filmes de Hitchcock, o momento da resolução de uma trama costuma, via de regra, desempenhar algum papel, seja ele conciliatório ou não, em Las Meninas de Picasso a construção do intrincado jogo de olhares instiga a "pulga atrás da orelha" sem apontar para qualquer solução diagnóstica. A série parece, antes, preparar o terreno para uma espécie de clímax a ser anunciado sem, no entanto, associá-lo ao prazer reconciliatório que provém da elucidação de um enigma qualquer.

Não à toa, quando Picasso afasta-se das composições em "primeiro-plano" para voltar-se a uma visão de conjunto, na décima terceira variação (fig. I6) de Las Meninas, o espelho que refletia no quadro de Velázquez o casal monárquico é reduzido a uma forma retangular em branco opaco, interceptada pela inscrição de um sinal em "X", uma forma hostil que, rasurada em bruscos traços negros e cortantes, chega a remeter à ossada de uma caveira. A mera existência desse sinal torna a imagem especular definitivamente banida de sua capacidade de reflexividade, como se indicasse uma anulação propositalmente sinalizada. Justo o espelho, objeto tão crucial à resolução dos enigmas epistemológicos que tanto instigaram estudiosos de Las Meninas. Além disso, essa variação caracteriza-se pelo emprego de uma palheta de cores intensas e virulentas que produzem um forte sentimento de compressão e claustrofobia, acentuado pelas dimensões compactas da tela. A composição parece, a uma só vez, asfixiar e repelir o observador, impendindo-o de projetar-se satisfatoriamente.

$\mathrm{Na}$ variação seguinte (fig. 20), a parede dos fundos do aposento (que na tela anterior havia sido pintada em tons de preto e branco através dos quais se podia entrever uma coloração vermelha que tingia todo o fundo da tela, remetendo aos tons rubros que irradiam por toda a pintura de Velázquez) é transformada em uma superfície cinza homogênea, espessa e ostensivamente opaca, como um muro de cimento de alta densidade no qual estão pregados telas e molduras também inteiramente grises. O ângulo que define o enquadramento dessa pintura é ligeiramente mais fechado que o da variação anterior, e a composição é concebida a partir de um ponto discretamente mais elevado. Desta vez, a tela utilizada tem dimensões um pouco superiores que a tela precedente, o que faz com que o efeito de proximidade e compressão da composição seja atenuado, embora a forte atmosfera de impacto permaneça. A sensação que temos ao ver as pinturas em sequência é a de que demos dois passos para trás, afastando-nos do conjunto de figuras. Esse movimento nos permite ver no canto inferior direito e em um azul brilhante, o verso da tela em que, na obra original, trabalhava o pintor. Somente isso, contudo, já que a figura do pintor ela mesma está ausente das variações em questão. 


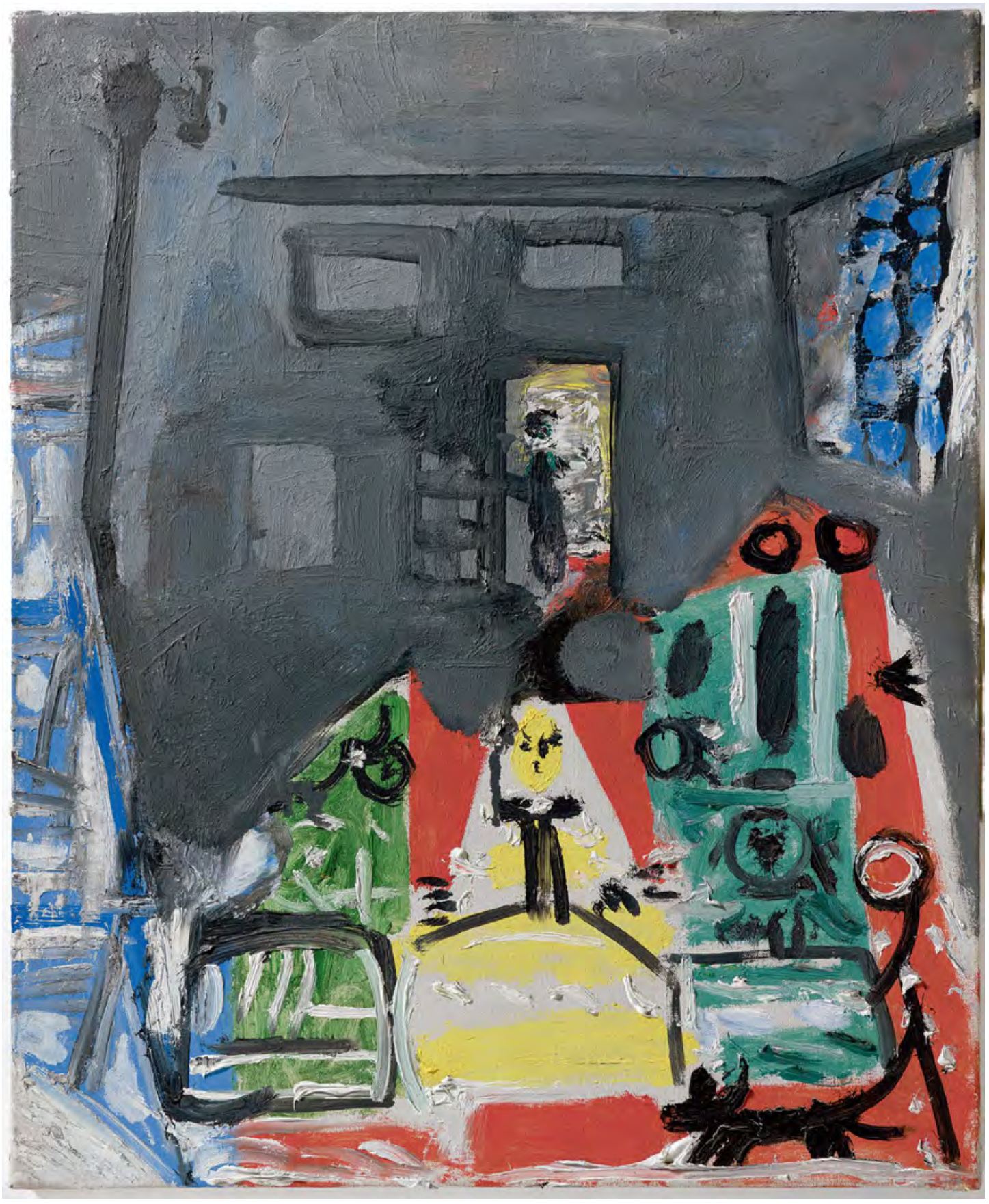

20 Las Meninas

Cannes, 4 de septiembre de 1957

Óleo sobre tela

$46 \times 38 \mathrm{~cm}$

Museu Picasso, Barcelona 
Excluídos o pintor e o reflexo especular, resta a presença da silhueta em sombras que, situada imediatamente acima da infanta, interrompe a cena. Isto é, os elementos que poderiam fornecer um significado para o quebra-cabeça epistemológico da pintura de Velázquez simplesmente não têm mais lugar, ao passo que a própria interrupção é intensificada enquanto evento. Não se trata mais de uma "epifania real", para usar a definição que Jonathan Brown fornece a Las Meninas de Velázquez, mas de uma epifania em si.

O que não significa que a silhueta que irrompe na espacialidade constricta seja necessariamente desprovida de identidade. Na pintura de Velázquez, ela foi identificada à de José Nieto Velázquez, aposentador da rainha. Cortesão que, por casualidade, levava o sobrenome do pintor, José Nieto - ou, precisamente, a figura que a ele corresponde - desempenha um papel fundamental em Las Meninas de Picasso. Se o pintor aparece somente em quatro das cinquenta e oito pinturas da série, o aposentador, por sua vez, faz-se sentir em treze delas. À exceção da princesa e da dama de companhia que lhe oferece água, ele é, curiosamente, quem mais marca presença na série. Nunca recebe atenção analítica (como é o caso das figuras que compõem o séquito da infanta) e, no entanto, está quase sempre situado em um ponto ápice de tensão e evidência.

O protagonismo de Don José Nieto - bem como a coincidência fatídica por trás de seu nome - foram sinalizados por Hubert Damisch em um dos mais brilhantes comentários a respeito das variações de Las Meninas de Picasso ${ }^{92}$. Sua análise se dá em circunstâncias bastante específicas: ela integra um estudo sobre as origens da perspectiva, no qual Damisch revisita Las Meninas de Velázquez e discute a posterior interpretação que Michel Foucault dá à pintura.

Segundo Damisch, as variações de Picasso são o mais vivo testemunho de que uma faceta de Las Meninas passou inadvertida pelo filósofo francês. Ela é revelada através

92 DAMISCH, Hubert. L'Origine de la perspective. Paris: Flammarion, 1987, pps. 436-455. É curioso que nos inúmeros escritos sobre a série até então, a importância seminal dessa figura como ponto fulcral da composição não tivesse sido notada. Pelo contrário, grande parte dos estudos enxergavam na infanta, nas damas de companhia e no pintor os principais motivos do afã decompositivo de Picasso, enquanto que José Nieto era tido como uma figura sem importância. Tome-se por exemplo: "Aparte de la infanta, de las meninas y el pintor, centra tambien en copiar las imágenes de aquellos a quienes ju juventud o carenciade facultades mantienes apartados de las intrigas palaciegas. Ciñiendonos a esta suposición, observemos la marginación en que se encuentran el aposentador, la dama y el guardaramas, quienes son tratados como si formaran parte del mobiliário de la sala en varias de las composiciones.", em Museo Picasso, catálogo de pintura y dibujo. Ajuntament de Barcelona, p. 698. 
de uma operação simples: investigando a correlação entre dois dos pontos cruciais da pintura, a saber, o espelho que reflete os monarcas e a abertura da porta que deixa entrever a silhueta do aposentador. Ao subtrair a centralidade do espelho e ao fixar (em composições mais compactas e carregadas que a de Velázquez) na sombra negra do aposentador o ponto fulcral da composição, Picasso desloca a atenção do que antes era o centro imaginário da composição para destacar seu ponto de fuga geométrico, que reside justamente no cotovelo da figura no umbral ${ }^{93}$.

Ponto este que, como sinaliza Damisch, não havia recebido a devida atenção na análise de Foucault, cuja reflexão sobre o estatuto da apresentação considera que o centro da composição em Las Meninas reside precisamente no espelho quando este, em realidade, é unicamente seu "centro imaginário". Eis o seu calcanhar de Aquiles: ignorar a tensão entre a estrutura imaginária da composição de Las Meninas e sua organização geométrica - o que, para Damisch, é parte crucial da ambivalência que permeia toda a economia da obra

Para demonstrar a importância desse ponto, nada melhor que recorrer às variações de Las Meninas de Picasso: cada uma delas, afinal, é fruto do trabalho de um artista que, nos anos de I950, não mais se propunha em dar ênfase àquilo que a pintura representa; antes, lançava-se à tarefa de potencializar o que ela pode fazer e, sobretudo, o que ela é capaz de transformar ${ }^{94}$.

Esse argumento, conforme o próprio Damisch reconhece, poderia ter vindo de qualquer defensor da Speech Act Theory. Isso porque o autor- à revelia de Foucault, que condenava o ato de dar nome às personagens do quadro de Velázquez, sob a defesa de que nomeá-los não passa de um artifício deíctico que permite superpor os registros da fala e da visão como se fossem adequados um ao outro - dá atenção especial ao jogo de linguagem criado pelos nomes próprios na pintura. Em particular, a uma conexão sintática singular: Diego Velázquez era pintor e aposentador do rei ${ }^{95}$, encarregado da coleção real de pintura, ao passo que José Nieto Velázquez era encarregado da coleção real de tapetes e aposentador da rainha.

93 O ponto de vista geométrico da pintura foi revelado em 1980 por SNYDER, op. cit.

94 DAMISCH, op. cit, p. 446.

95 Conforme já assinalaram muitos autores, a chave que se vê dependurada no cinturão do pintor é um indício que demarca seu cargo como aposentador, e está assinalado na economia simbólica da pintura. Veja-se BROWN, Jonathan. "Sobre el Significado de Las Meninas", in Fernando Marías (ed.). op. cit., p. 75. 
De sorte que não há somente um Velázquez na tela, mas dois. Um deles pinta o quadro e o outro situa-se no preciso ponto em que o observador, por correspondência, encontra o seu lugar no quadro. Tudo se torna mais conspícuo com a virulenta confluência entre os gestos de um e de outro: o pintor, em plena atividade, nos olha enquanto segura, em suspenso, o pincel; o aposentador, postado entre os degraus de uma escada, levanta o braço para suspender o peso da cortina ${ }^{96}$. Seria José Nieto - a testemunha, conforme a definição de Damisch - uma espécie de duplo do pintor em Las Meninas de Picasso?

Interpretações menos sofisticadas que a de Hubert Damisch também notaram a convergência e identificação entre os papéis do pintor e do observado em Las Meninas de Picasso $^{97}$. Susan Grace Galassi chega a admitir a hipótese de que em uma das variações de Picasso a porta vermelha ao fundo da composição pode ser vista como um quadro sendo pintado por José Nieto, um duplo em exercício do pintor nessa obra e, por consequência, do próprio Picasso.

96 Os curiosos por relações matemáticas logo puderam demonstrar que, se o gesto do aposentador coincide com o ponto de fuga da pintura, o gesto do pintor está no cerne de uma espiral que ocupa toda a extensão horizontal da tela e que obedece à proporção áurea.

97 Cf. GALASSI, op. cit., p 145-7.. Levando essa conexão adiante, a autora defende que Picasso escolhe confrontar a autoridade de Velázquez reivindicando seu lugar ao lado do grande mestre, como em uma espécie de desafio. A leitura de Galassi, de uma maneira ou de outra, faz recordar uma clássica interpretação de Las Meninas de Velázquez que postula que o quadro foi realizado, em última instância, com a intenção de reivindicar o estatuto da pintura como arte liberal, e, com isso, seu lugar proeminente como pintor na corte espanhola. É como se, ao interpretar Las Meninas, Picasso demandasse ser reconhecido ao lado dos grandes mestres da pintura, do mesmo modo que Velázquez, ao conceber sua obra, pleiteasse seu lugar no alto escalão da sociedade em que vivia. Para sustentar seu argumento, a autora chega a sugerir que, não à toa, Picasso introduz Lump, seu próprio cachorro de raça dauschund, no lugar do mascote que se situa no canto inferior direito da pintura de Velázquez. A referência ao cão de estimação de Picasso - que não é trazida à tona somente por Galassi mas por muitos outros autores - foi evocada em um dos primeiros textos sobre Las Meninas de Michel Leiris, escrito na ocasião de uma exposição da série na Galeria Louise Leiris, em Paris, em 1959. Michel Leiris, no entanto, não fazia nenhuma menção à reivindicação de maestria por parte de Picasso: o argumento do autor era que as figuras de Las Meninas de Picasso tinham que estar imbuídas de um universo familiar, de um sentido de proximidade capaz de animá-las. Ideial de "familiaridade" e "proximidade" que Leiris, desde os anos 1930 e mesmo antes, vinha defendendo como traço característico da obra de Picasso. 
As complexas operações levadas a cabo na série de Picasso, no entanto, não se resumem a acentuar o papel duplo que José Nieto desempenha em Las Meninas. Mesmo Damisch chega a admitir que essa é apenas uma dentre as várias operações de que o artista lança mão ${ }^{98}$. Sua análise da série de pinturas em questão é pontual e sucinta e não custa reiterar - integra um estudo ambicioso sobre as origens da perspectiva na arte ocidental. De modo que por trás dela reside o interesse por uma discussão e uma revisão crítica da interpretação que Foucault dá a Las Meninas de Velázquez, e talvez seu maior objetivo não seja esgotar as possibilidades analíticas sobre a série de Picasso, mas fazernos atentar àquilo que tanto a Foucault quanto aos textos e estudos posteriores ao dele passara desapercebido no que concerne à estrutura da pintura seiscentista.

Resta, portanto, a questão: quais então seriam as outras operações que Picasso realiza em sua série? Uma delas quiçá possa ser extraída diretamente das asserções de Damisch: ela consiste não somente em explorar a tensa relação entre o centro imaginário da composição e seu ponto de fuga geométrico, mas também - e, ao meu ver de modo ainda mais incisivo - em destrinchar o enredado liame entre ambos esses pontos e a emblemática figura da infanta Margarita María em primeiro plano.

Quando Damisch considera que as variações de Picasso se controem sob a tensão entre a silhueta do aposentador e o espelho (ou entre o "centro geométrico" e o "centro imaginário" de Las Meninas de Velázquez), ele assume que a pintura seiscentista está estruturada a partir de dois pontos fulcrais. Isso porque se considerarmos o ponto de vista do espectador, a construção perspectiva converge, como dissemos, para a figura de José Nieto. Em contrapartida, se tomarmos as dimensões fictícias do aposento pintado, o centro da composição (que Damisch qualificou como imaginário) reside justamente no espelho com a imagem dos soberanos - para assegurar-nos disso, basta seguir as lâmpadas penduradas no teto e localizaremos esse ponto com precisão.

Por outro lado, se adotarmos como referência a largura da tela empregada,

98 Considere-se: "Sobre o que trabalhou Picasso, na realidade? Entre outras coisas, sobre a relação entre o espelho em que se refletem as figuras dos soberanos (e que Foucault situa no centro do quadro) e a porta imediatamente a seu lado, que emoldura, arrancando de alguns degraus de escada, a silhueta de um terceiro personagem", em DAMISCH, op. cit., p. 446. Tradução livre e grifos da autora da dissertação, do original: "Sur quoi Picasso a-t-il travaillé, en effet? Entre autres choses, sur le rapport entre le mirroir où se reflètent les figures des souverains (et que Foucault situe au centre du tableau) et la porte qui le jouxte et où s'encadrent, au départ d'une voie d'escalier de quelques marches, la silhouette d'un tries personnage". 
descobriremos um eixo mediano cortando a figura da infanta, exatamente em seu olho esquerdo - o que nos leva a crer que o quadro se estrutura, como mínimo, a partir de três centros, e não somente dois ${ }^{99}$. Não é insignificante o fato de que muitos dos primeiros comentadores de Las Meninas, a exemplo de Justi e outros, tenham considerado a infanta Margarita Maria como motivo central da pintura: ela está rodeada por seu séquito, em primeiro plano. Sua presença certamente salta aos olhos do observador antes do pequeno reflexo especular na parede de fundos do aposento, ou mesmo antes da figura daquele emissário que, à distância, observa a cena.

De modo que quando Picasso reduz a imagem do espelho a um signo sem remissão especular e insiste em associar e dissociar as figuras da infanta e do aposentador uma da outra, ele revela uma percepção acurada de que a pintura de Velázquez opera a partir de uma hierarquia instável entre esses três pontos centrais.

Nunca é demais recordar que na primeira variação de Las Meninas (fig. 2), José Nieto situa-se num local diretamente acima da infanta, sendo ela o ponto mais iluminado e ele o mais sombrio da composição. Que o artista, após realizar essa primeira variação, produz doze pinturas dedicadas ao escrutínio individual de figuras, das quais onze são dedicadas à princesa. Que, quando volta-se outra vez a uma vista de conjunto, na décima terceira pintura, posiciona a infanta e o aposentador, outra vez, no mesmo eixo vertical da pintura - e não em um qualquer, mas no eixo central. Que a cor amarela que irradia do vestido da menina é a mesma que jorra do vão da porta onde se encontra o aposentador. E que na próxima pintura infanta e cortesão seguem emparelhados, ele imediatamente acima dela.

Tudo se torna mais emblemático ao notarmos que, em seguida, nas variações de número quinze, dezesseis e dezessete (figs. 2I, 22), Picasso volta a apurar a expressão da menina, e, dessa vez, o faz de um modo completamente distinto. Abandonando os traços esquemáticos e lineares que havia adotado nos últimos retratos da infanta, parte para uma espécie de inspeção psicológica de seus traços, dando vazão ao modo como certas particularidades fisionômicas são dotadas de poder expressivo ${ }^{\mathrm{IoO}}$. É como se, após realizar

99 A existência de ao menos três centros estruturais para a composição de Las Meninas de Velázquez foi apontada por Steinberg. Considere-se: "Perguntemos onde localiza-se o centro e como resposta a pintura não apontará a um e nem a dois determinados pontos, mas a três ou a quatro; isso depende de onde estivermos centrando nosso foco". STEINBERG, 1981, op. cit., p. 51. Traduzido livremente do original: "Ask where the center is, and the answer returned by the picture is not any one point, nor any two, but three and four; it depends on what you are centering." 
o par de pinturas que colocam em evidência a figura do aposentador, Picasso mudasse radicalmente de registro para adentrar a interioridade da infanta - sugerindo, a partir da cadeia sequencial, uma relação entre a expressão fisionômica da menina e aquilo que acaba de ocorrer na pintura anterior, isto é, a aparição da silhueta misteriosa. De modo que aos poucos o elo que une a garota à figura que a espreita no batente da porta se torna cada vez mais pronunciado.

Sob determinado ponto de vista, esses três retratos de densidade psicológica sinalizam o encerramento de uma primeira parte da série. Pois nas próximas pinturas Picasso afasta seu olhar da obra de Velázquez e dedica-se a pintar a vista da janela do aposento em que pintava no terceiro andar de La Californie. Essas pinturas constituem uma espécie de interlúdio entre sequências com pronunciadas diferenças entre si e, a princípio, parecem fruto de uma escolha aparentemente aleatória, mas, ainda assim, mantêm um nexo de proximidade com o restante da série. Voltaremos a uma análise mais detida dessas pinturas adiante. Antes, contudo, retenhamo-nos mais detidamente na forma com que Picasso explora a instabilidade entre os três centros de Las Meninas. Para isso, sugiro que retrocedamos alguns anos na história da pintura.

\section{A testemunha ocular}

Las Meninas de Velázquez não foi a primeira obra a colocar em evidência um emissário que, desde o fundo do campo pictural, observa uma cena ou um acontecimento em primeiro plano. Este é, ao menos desde o século XV e se não antes, um motivo conhecido da pintura ocidental. Devemos ao vasto repertório da pintura religiosa que exalta a animação de um registro maravilhoso as origens remotas desse recurso, que funciona como um elemento mediador entre a experiência do observador e o acontecimento retratado em primeiro plano. É justamente a natureza dessa mediação que nos interessa.

Tome-se como exemplo A ressureição de Lázaro (I5I4-I5I9), pintura atribuída a Juan de Flandres e hoje no Museu do Prado (fig. 23). Ela apresenta, em primeiro plano, Jesus abençoando Lázaro ressuscitado em presença de seus apóstolos e de Maria Madalena. Curiosamente, como se para agregar veracidade a sua narrativa, o pintor adiciona, 
ao fundo da composição, um grupo de judeus ultrajados que vêem a cena através de uma porta. Ninguém parece prestar-lhes atenção: o que os une ao grupo em primeiro plano é a remissão a um mesmo fato presenciado, do qual são apenas testemunhas. Pois se para Jesus, Lázaro, os apóstolos e Maria Madalena, esse fato é vivenciado como experiência extática, para os judeus, ele se dá a ver somente como experiência óptica.
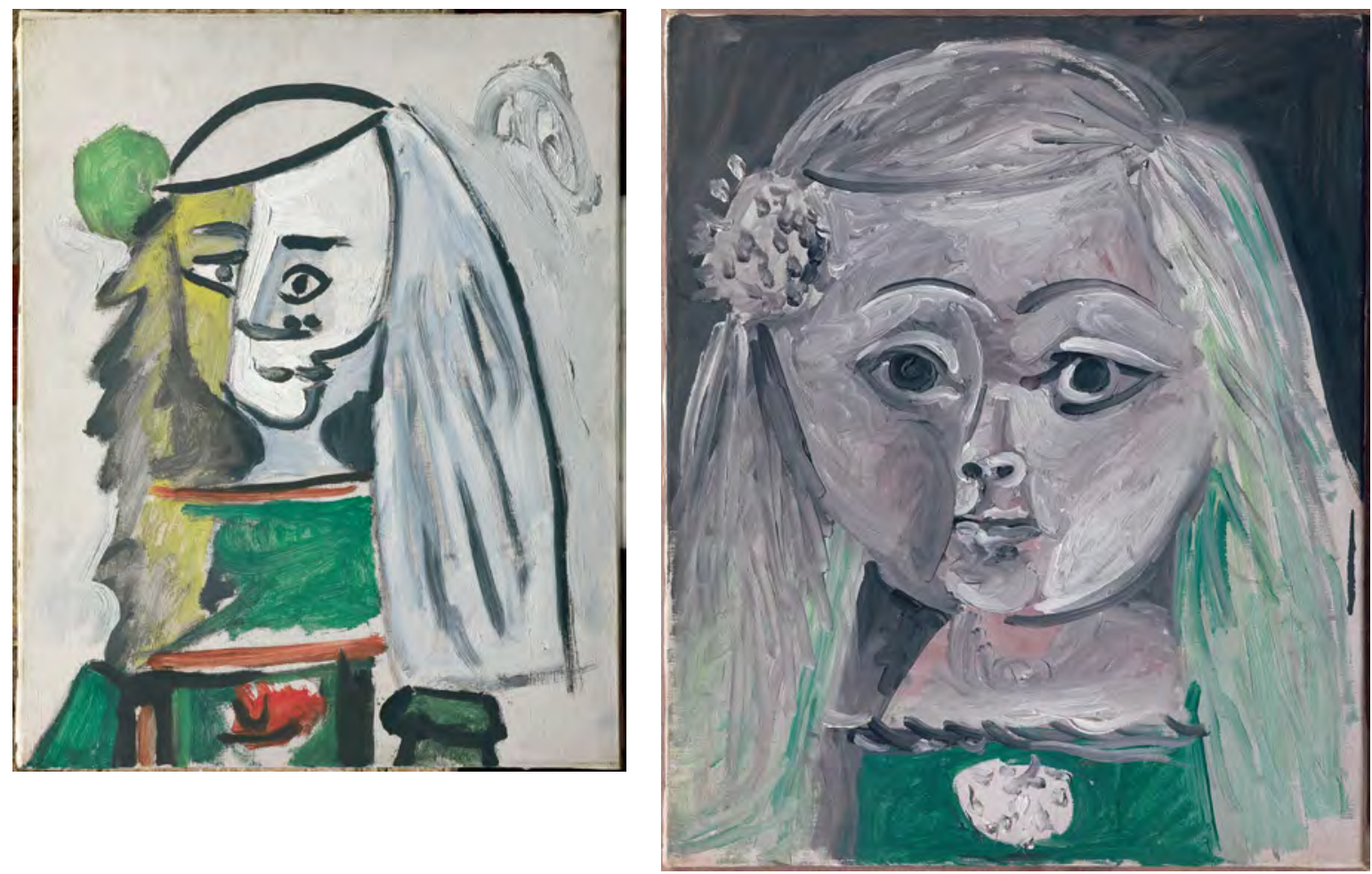

21 Las Meninas [infanta Margarita María] Cannes, 6 de setembro de 1957

Óleo sobre tela

$41 \times 32,5 \mathrm{~cm}$

Museu Picasso, Barcelona
22 Las Meninas [infanta Margarita María]

Cannes, 6 de setembro de 1957

Óleo sobre tela

$46 \times 38 \mathrm{~cm}$

Museu Picasso, Barcelona 
Uma versão um pouco anterior de A Ressurreição de Lázaro (I450-I460), de autoria de Aelbert van Ouwalter (fig. 24), nos põe frente a uma situação semelhante ${ }^{\mathrm{Ior}}$. A cena se passa no interior de um recinto que remete a uma igreja romana. Em primeiro plano e no eixo central da composição, vemos Lázaro ressuscitado, rodeado por diversas figuras que atestam a veracidade do milagre que acaba de suceder. Por trás, um aglomerado de rostos curiosos observa a cena através de grades. Eles fazem parte da assembleia que presencia a ressurreição, mas são representados em um plano separado da ação. Trata-se, conforme sinaliza Victor Stoichita, de figuras eco[figures-écho] ${ }^{\mathrm{Io2}}$, as testemunhas oculares de uma ação que, como no caso anterior, têm por função ajustar o espaço da imagem para que ele seja visualmente perceptível sem ser fisicamente praticável. E que têm por objetivo, ainda, atenuar a contradição entre a visão de um acontecimento sagrado e sua representação como fato dado à contemplação pública. Segundo Stoichita, o surgimento dessas figuras nos séculos XV e XVI não pode ser separado do florescimento, na Europa Ocidental, do paradigma perspectivo e do modelo integrado de visão que ele institui. À medida em que foram incorporadas a um sistema centrado em um ponto de vista unificado, elas passaram a ser integralmente concebidas em relação ao próprio observador e à sua posição implícita - como uma espécie de apelo que lhe aporta indicações suplementares à sua percepção ${ }^{\mathrm{IO} 3}$. Não à toa, veem através de grades enquanto nós, espectadores, temos acesso à cena sem quaisquer impedimentos.

Será sobretudo no século XVII que essas figuras que tematizam o olhar se tornarão objeto de obsessão da pintura. Elas aparecem, por exemplo, na célebre Decapitação de São João Baptista (I608), de Caravaggio (fig. 25), uma tela horizontal de grandes dimensões estruturada a partir de uma composição que, como é frequente em sua obra, coloca sob tensão as ortogonais e diagonais da pintura. No eixo central vemos, em dimensões humanas, João Baptista executado por um carcereiro que carrega em uma das mãos um punhal e em outra a cabeça do defunto, de cuja garganta jorra o sangue recém derramado. À esquerda, um grupo de três figuras integra a ação, entre as quais Salomé, que

101 Um comentário sobre essa pintura pode ser conferido em: STOICHITA, 2015, op. cit., pp. 14-16.

102 Em uma breve análise da pintura Saint Paul Preaching at Athens, de Rafael Sanzio, Ernst Gombrich denomina eye-witness as figuras com função semelhante às que Stoichita havia descrito como figures-eco. Cf. GOMBRICH, E. H. The Image and The Eye. Londres: Phaidon, 1986, p. $255-256$

103 STOICHITA, 2015, op. cit., pp. 14-16. 
segura uma bandeja para receber a cabeça degolada de João Baptista. Estendendo-se por quase toda a porção direita da pintura, vemos uma parede em tons de ocre entrecortada pela abertura de uma janela gradeada, através da qual duas figuras observam a cena, dirigindo seu olhar ao centro do quadro (que é também o centro do ambiente retratado). Como o ato da execução é concebido a partir de um movimento rotacional em diagonal, o acesso interno que essas figuras têm do evento dramático é precisamente o da visão em profundidade: elas vêem o inverso da cena representada, isto é, o dorso do carcereiro que apunhala o santo - que, diga-se de passagem, configura uma imagem de forte impacto e apelo visual. Essas figuras possuem uma dupla função: por um lado, seu olhar curioso instiga e reverbera nossa própria curiosidade de ver enquanto espectadores externos, personificando uma visão em ricochete que nos permite circundar a ação protagonizada em sua totalidade. Não só nosso olhar é reverberado por estes duplos em exercício, como ele é também potencializado por eles: enquanto os presos tem a sua visão dificultada pelo gradeado da janela, nós, por antítese, temos acesso à cena sem qualquer obstáculo, e, ainda, desde uma perspectiva frontal avantajada. Vemos mais e melhor que eles. Do que se depreende que as figuras-eco, nesse caso, não só aguçam nossa curiosidade visual como também asseveram-nos do apanágio de ver sem entraves ${ }^{104}$.

A cena pictural do século XVII (da qual Velázquez fez parte e na qual atuou de forma decisiva) frequentemente apelava para esse puro modo de sugestão que estimula e satisfaz a curiosidade escópica do observador ao mesmo tempo em que assegura seu ponto de vista privilegiado. Trata-se de um artifício tão poderoso para despertar a curiosidade visual e alvitrar a ilusão estereométrica que, não à toa, foi frequentemente utilizado na representação de temas alusivos à visão e ao desejo (David e Batsheba, Suzanna e os Velhos, etc).

O motivo da figura que personifica a visão em ricochete podia ainda desempenhar, paralelamente, uma outra função: não somente a de testemunha óptica, como, além disso, a de figura em aparição que, postada no fundo da pintura, funciona de modo a intensificar consideravelmente o fator surpresa da cena ocorrida em primeiro plano, reforçando seu caráter instantâneo. André Chastel, que buscou mapear as origens do motivo em Las Meninas, recorre à pintura Os Mártires Cecilia, Valério e Tibúrcio visitados por um anjo (c. I606),

104 Ibid, p. 11- 45. O autor demonstra como Manet dialoga com essa tradição que tematiza o olhar com entraves, subvertendo-a em pintura como O Caminho de Ferro. 

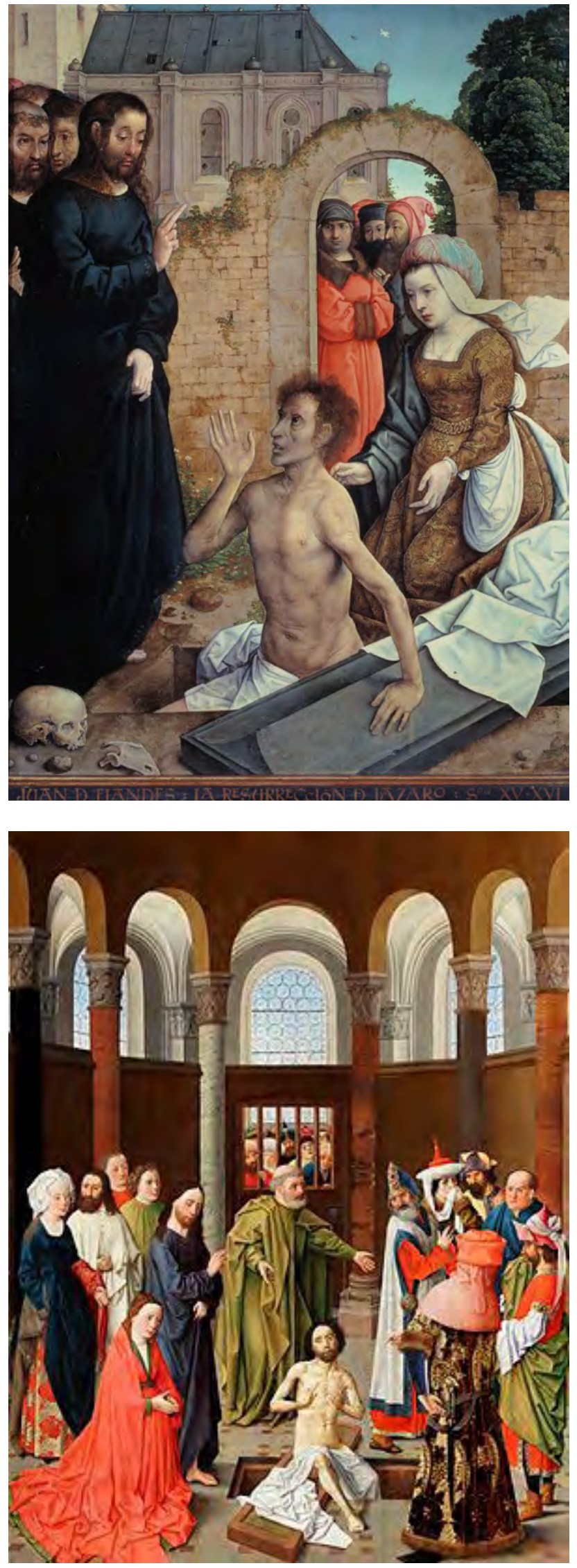

23 Juan de Flandres

A Ressurreição de Lázaro, 1514-19. Óleo sobre tela $110 \times 84 \mathrm{~cm}$

Museu do Prado, Madrid

24 Albert van Ouwater

A Ressurreição de Lázaro, c. 1460 Óleo sobre tela $124 \times 92,7 \mathrm{~cm}$

Gemäldegalerie, Berlin. 


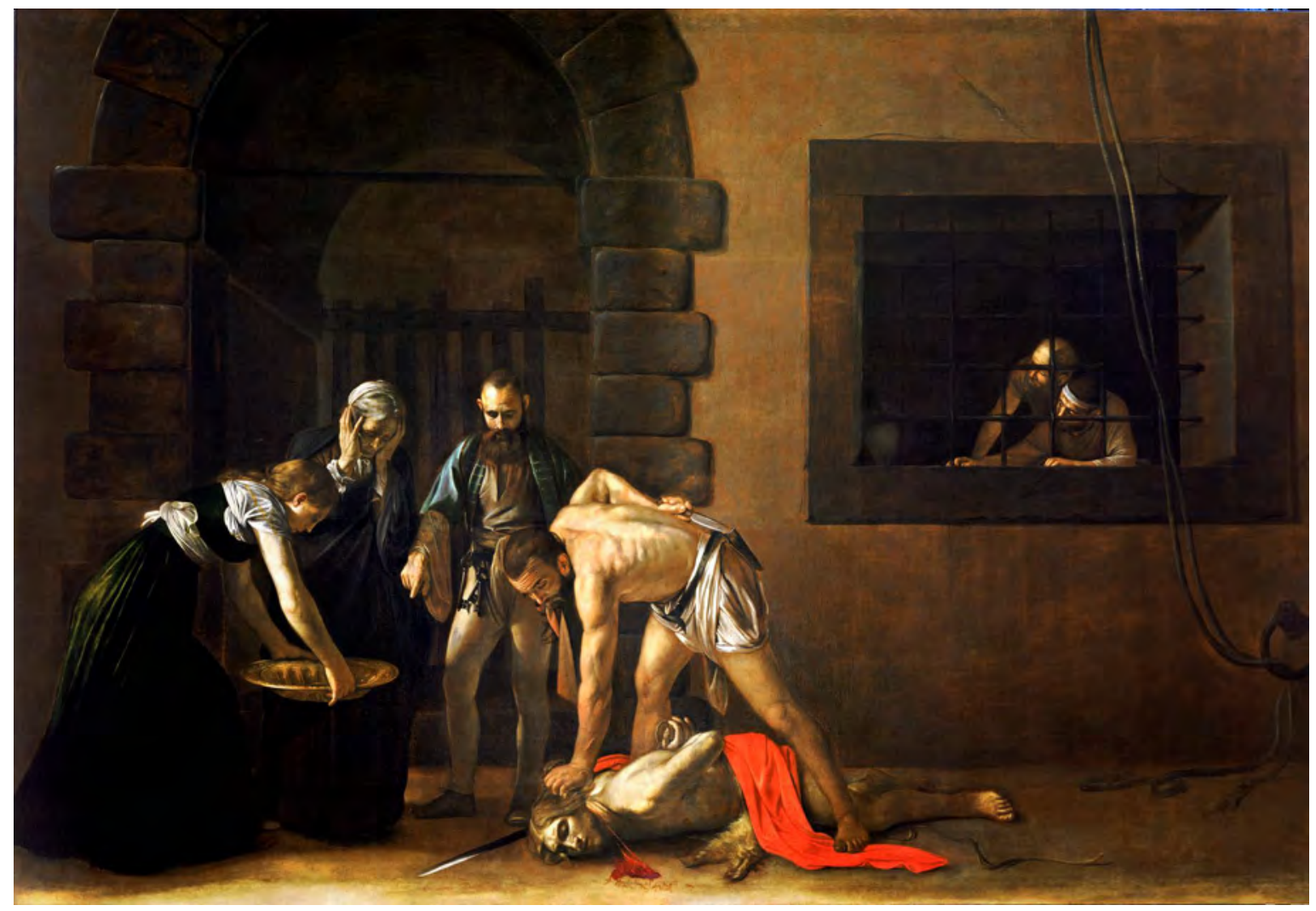

25 Caravaggio

Decapitação de São João Baptista, 1608.

Óleo sobre tela

$370 \mathrm{~cm} \times 520 \mathrm{~cm}$

Co-Catedral de São João. Valeta, Malta. 
de Orazio Gentileschi (fig. 26) para ilustrá-lo ${ }^{105}$. A pintura apresenta, em primeiro plano, um anjo que aparece a Cecília e a seu marido Tibúrcio para anunciar-lhes o casamento. A aparição é presenciada por Valério, irmão do noivo, que, impressionado pela visão que se descortina a sua frente, ergue a mão na tentativa de tocar os pés do anjo para conferir sua veracidade. Observando a cena em segundo plano e postado na soleira de uma porta, a figura de Valério não deixa de funcionar, a exemplo dos casos acima comentados, como uma testemunha óptica que presencia a experiência visionária, borrando as fronteiras entre a visão como experiência extática e fato ocular. Mas ela funciona também, de modo paralelo e complementar, para avivar o caráter inesperado e extraordinário do acontecimento presenciado, a saber, a aparição do anjo.

Se nos voltarmos a Las Meninas, no entanto, veremos que é difícil determinar em que exatamente consiste o acontecimento em questão. Difícil também é saber se José Nieto estaria saindo ou entrando no aposento: há quem tenha interpretado seu movimento como prenúncio de uma entrada, e há, por outra parte, quem diga que ele é a preparação para uma retirada ${ }^{106}$. Alguns, ainda, enxergaram em seu gesto uma espécie de apresentação de mise-en-scène, que revelaria, por trás da cortina, a presença de uma plateia oculta ${ }^{\mathrm{IO}}$.

Além disso, o efeito de suspensão temporal e de instantaneidade em Las Meninas, como vimos, também sugere uma interrupção abrupta de uma cena de intimidade. Nesse caso, a hipótese de que a figura de José Nieto constitui uma figura em aparição que confere instantaneidade à pintura parece perfeitamente plausível. O que não exclui as consequências de sua presença como testemunha ocular. Isto é, seja qual for sua função, essa figura não deixa de focalizar o aspecto intorso do que vemos em primeiro plano, agindo, simultaneamente, em relação ao acontecimento e à nossa visão. Embora o faça de um modo diferente das pinturas comentadas até então: se, nelas, a presença de figuras postadas nos recônditos do campo visual estimulava e satisfazia a curiosidade e o desejo de ver do observador, nesse caso, a satisfação, em sentido pleno, não se completa.

Isso porque se considerarmos o acontecimento que têm lugar em primeiro plano, talvez seja José Nieto quem assuma um lugar privilegiado na estrutura do quadro.

105 André CHASTEL, "La Figure dans l'encadrement de la porte chez Velázquez", em Fables, Formes, Figures II. Paris: Flammarion, 1978, pp. 145-155.

106 Foucault resolve este impasse dizendo que o aposentador "entra e sai ao mesmo tempo". Ver FOUCAULT, 1966, op. cit, p. 26.

107 ibid., p. 149. 
Essa figura, de seu ponto de vista, tem acesso ao espetáculo para o qual muitas das personagens dirigem o olhar e que nos é inacessível. Tem acesso, também, ao dorso do artista e à imagem que ele pinta, que a nós só é oferecida como um reverso opaco. Além disso, ele é o único que vê a todos sem ser visto. Ou, como o espelho, é visto por nós, mas somente como pura remissão daquilo que não podemos acessar.

Quanto a isso, não podemos ignorar que Picasso estava perfeitamente ciente das consequências ópticas e dramáticas de uma testemunha ocular na pintura. Conhecia tão bem a eficácia que têm esse modo barroco para despertar e estimular a curiosidade do espectador que o havia utilizado em muitas pinturas desde sua juventude. Em suas variações de Las Meninas, no entanto, ele parece tirar partido do fato de que, mesmo na pintura de Velázquez, José Nieto não configura exatamente uma testemunha ocular, em sentido convencional. Pois ele não opera exatamente em colaboração com a nossa visão: pelo contrário, ele aguça nossa curiosidade visual sem, no entanto, recompensar-nos com a garantia de um lugar privilegiado, mas somente para revelar-nos os limites de nosso próprio olhar.

De modo que quando Damisch destaca o interesse de Picasso por essa figura, não demonstra somente que o artista detectou o ponto de fuga geométrico da pintura de Velázquez, mas sinaliza algo mais. Pois é por meio do aposentador que Picasso faz com que o observador anteveja, através das linhas inegáveis de projeção ocular, que tudo aquilo que sua visão abarca e tudo aquilo que é incapaz de abarcar expõe ao outro uma face que, a ele mesmo e a todas as figuras retratadas na cena, lhes escapa por princípio. Essa silhueta é, ao mesmo tempo, o ponto de projeção do espectador e seu avesso imprevisível. É, em outros termos, a evidência opaca da visão que se revela mediante um sistema translúcido de linhas de convergência.

Nesse sentido, a aparição do aposentador opera simultaneamente como clímax e anti-clímax da série. Isso porque desde as primeiras variações de Las Meninas, Picasso já parecia querer instar nossa curiosidade conduzindo-nos através de sua analítica perscrutadora dos gestos disruptivos da infanta. Tanto é que já estamos curiosos quando o artista abre o plano de representação e nos permite ver, imediatamente acima dela, a figura do aposentador eclodindo no espaço pictórico.

Mas ainda que nossa curiosidade seja brindada pela visão da silhueta dessa figura, sua eclosão não está associada à resolução de qualquer enigma que sacie o desejo de espreita. Evidentemente, podemos especular sobre a relação entre uma figura e outra, mas o que a irrupção de José Nieto nos expõe é somente nossa própria curiosidade em questão. 
Se o artifício barroco de tematizar a visão em ricochete fazia com que víssemosas figuras-testemunha vendo, agora a relação se inverte: o aposentador, que vê mais do que nós, também nos vê vendo. Ele é, em sua potência anti-projetiva, não uma testemunha ocular, mas um flagrante. Flagrante de nossa própria visão, que deixa de revestir-se de sentido demonstrativo para revelar-se somente enquanto instrumento especulativo.

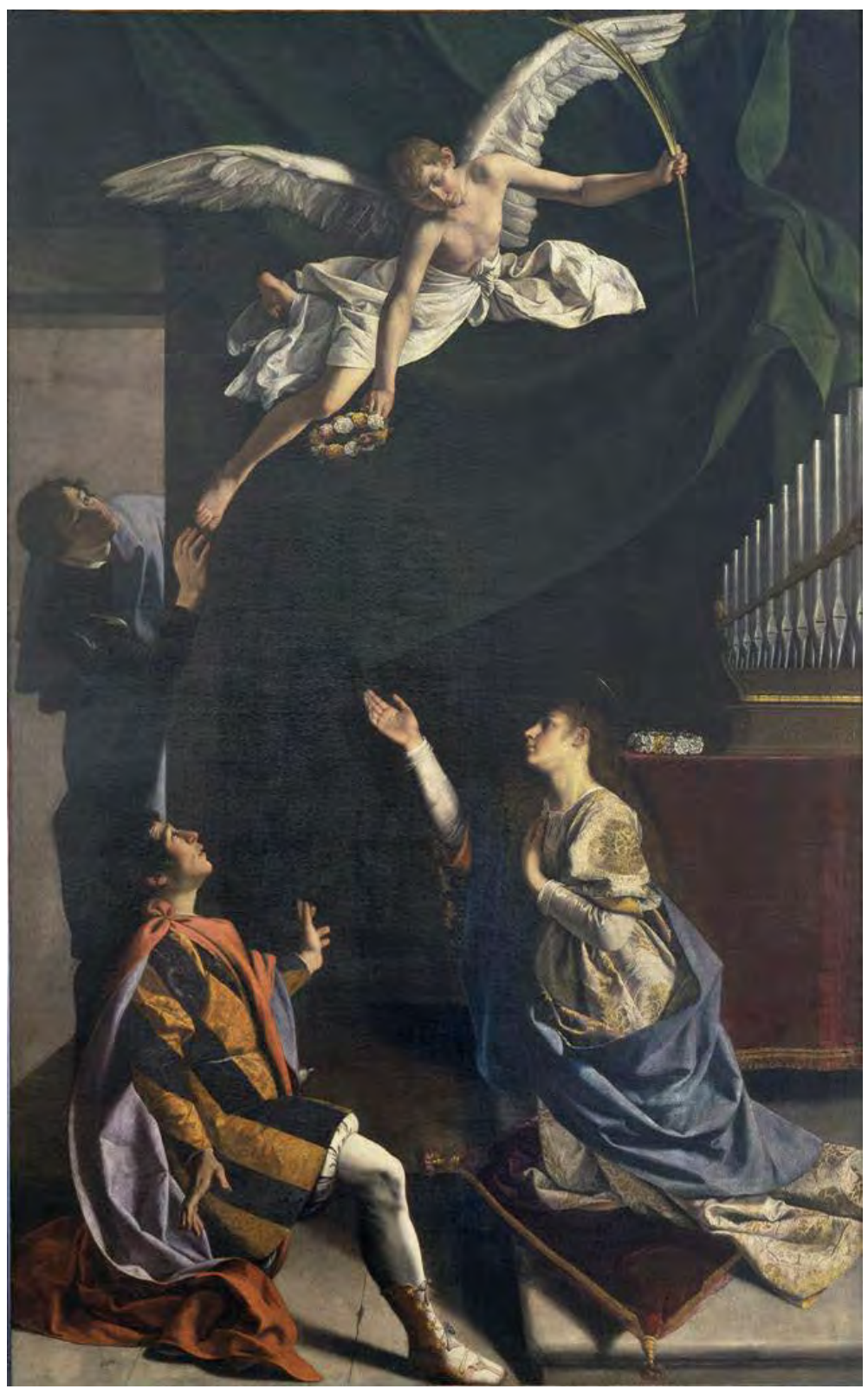

26 Orazio Gentileschi Os Mártires Cecilia, Valério e Tibúrcio visitados por um anjo, c. 1606 Óleo sobre tela, 350 × $218 \mathrm{~cm}$ Pinacoteca de Brera, Milão. 



\section{INTERLÚDIO}

Havíamos dito que os três retratos da infanta que sucedem às pinturas de conjunto marcadas pelo aparecimento de José Nieto delimitam, sob certa perspectiva, o fim de uma primeira parte de Las Meninas. Isso porque dia 06 de setembro, após pintar os dois últimos retratos da menina, Picasso sinaliza uma mudança radical em seu enfoque.

Em uma tela de maiores dimensões, retrata a vista da janela do aponsento em que trabalhava em Cannes, mostrando não somente a exuberante paisagem natural mediterrânea, mas também um grupo de pombos postados ao acaso em galhos ou ciscando comida aleatoriamente (fig. 27). Pombos enquadrados por pombos, já que as paredes do aposento em que Picasso escolheu trabalhar no sul da França eram repletas de gaiolas desses animais de estimação.

As oito variações seguintes (figs. 27-30, 33), pintadas entre 06 e I4 de setembro, giram em torno desses mesmos motivos: janela, pássaros e o mar. Elas, a princípio, pouco têm a ver com o que se vê na pintura de Velázquez, com as variações imediatamente anteriores ou com as variações por vir, e cindem a série desmembrando-a em dois grandes grupos de pinturas. Mas Picasso, sem relutar, optou por mantê-las unidas como parte integral do conjunto. A que se deve a mudança abrupta e a determinação por sustentá-la enquanto propósito?

"A necessidade por diversão após a intensidade do seu envolvimento com Velázquez é compreensível, o que é menos evidente é porque Picasso via as pinturas de pombos como parte integral da série ${ }^{\mathrm{I} 08 "}$, dirá Galassi. Buscando responder a si mesma, propõe:

Neste subconjunto de imagens da série Las Meninas, todavia, Picasso mantém em evidência seu tema principal: ele continua a explorar a relação problemática entre arte e verdade (ou entre a imagem pintada e seu equivalente no mundo físico) em um foco mais estreito - através da familiar analogia pintura/janela. ${ }^{109}$

\footnotetext{
108 GALASSI, op. cit., p. 142.

109 Idem, traduzido livremente do inglês: "In this sub-set of pictures within the Meninas series, Picasso keeps his major theme in evidence, however: he continues to explore the problematic
} 
Amparada pela interpretação estruturalista que Foucault faz sobre Las Meninas, a autora defenderá que as exuberantes vistas da janela de La Californie são mais um indício de que para Picasso - fundador do cubismo - o grande foco de interesse na execução de Las Meninas reside precisamente no abismo irresolúvel entre "signo pintado" e "significado" - do mesmo modo como teria sido a relação entre "aparência" e "realidade" o seminal interesse de Velázquez ao dedicar-se à pintura. Ambos os binômios apontariam para a "impossibilidade de qualquer verdade absoluta".

De acordo com Galassi, tanto Velázquez como Picasso, ao fim e ao cabo, se interessariam - cada qual à sua maneira - por explorar uma mesma relação problemática: a relação entre pintura e representação. Nada poderia ser mais adequado, portanto, do que aludir ao paralelo entre pintura e janela, tal como formulado por Alberti já no século $\mathrm{XV}{ }^{\text {IIo }}$.

O argumento não me parece consistente. Nunca é demais recordar que "sem dúvida", nas palavras de Hubert Damisch, "a transformação operada por Picasso tem lugar em um contexto totalmente distinto daquele do quadro que lhe fornece matéria prima: a pintura não estava mais, em I957, na era da representação" "II . E que, além disso, a janela como forma simbólica capaz de revelar a "verdade" ou a "realidade" do mundo havia sido problematizada, desde, ao menos, o século XVII, sendo sistematicamente colocada em causa no decorrer dos séculos XVIII e, sobretudo, XIX ${ }^{112}$.

relationship of art and truth (or the painted image and its counterpart in the physical world) in a more contracted focus - through the familiar painting/window analogy".

110 ALBERTI, León Batisti [1435]. Da Pintura, 2a. Ed., Campinas: Ed. Unicamp, 1999. Diversos são os estudos que comentam Alberti e a noção de que a janela seria modelo e metáfora para a pintura. Elenco: DAMISCH, op. cit.; BELTING, Hans. "A janela e o muxarabi: uma história do olhar entre Oriente e Ocidente", em Pensar a Imagem, Emmanuel Alloa (org.), Belo Horizonte: Autêntica Editorial, 2015, pp. 115-138; CHARBONNIER, Louise. Cadre et Regard: Généalogie d'un dispositif, Paris: l'Harmattan, 2007.

111 DAMISCH, op. cit., p. 448, traduzido livremente do original: "Sans doute la transformation de Picasso prend-elle place dans un tout autre context que le tableau qui en a fournit la matière: la peinture n'était plus, en 1957, à l'âge de la representation".

112 No século XVII, refiro-me, sobretudo, à pintura holandesa, que diferia em muitos aspectos do modelo italiano (cf. ALPERS, Svetlana. A arte de descrever: a arte holandesa no século XVII. São Paulo: Edusp, 1999). Em rigor, pode-se atribuir a esse período a primeira crise da janela como forma simbólica, pois, como argumenta Hans Belting, a cena pictural barroca (da qual Velázquez fazia parte) já problematizava a equivalência entre janela e pintura. Para o autor, o século XIX, com o romantismo alemão de Caspar David Friedrich, retoma esse questionamento de forma distinta. As pinturas de Friedrich repaginam a analogia de modo bastante consequente quando inserem um espectador contemplativo frente à janela. C.f. BELTING, Hans, op. cit., p. 123-4. 
A começar pela premissa de seleção e ordenamento que lhe preside: "inicialmente", postula Alberti, "onde devo pintar traço um quadrângulo de ângulos retos, do tamanho que me agrade, o qual deputo ser uma janela aberta por onde possa eu mirar o que será pintado ${ }^{113}$." Segundo o tratadista italiano, o artista deveria utilizar-se das esquadrias da janela como uma moldura, uma forma de enquadrar, uma ferramenta de seleção, um artifício compositivo (fig. 3I). Artifício este de que a cena pictural francesa oitocentista já havia prescindido com seus enquadramentos aleatórios, fragmentários, com suas cenas urbanas passageiras. As esquadrias da janela, no século XIX, não mais se abriam para uma cena ordenada, mas para um recorte arbitrário, que é apenas mais uma fração contingente de uma realidade em incessante movimento.

A prerrogativa da transparência, igualmente implícita na analogia pintura/ janela, foi também alvo de inquirição pela pintura do século XIX. Victor Stoichita demonstrou como Manet e outros, dentre eles Degas, Monet, Berthe Morrissot e Gustave Caillebotte frequentemente tematizavam em suas obras a dificuldade de olhar ${ }^{\mathrm{II} 4}$. Mobilizando, na estrutura mesma da pintura, barreiras recalcitrantes, obstáculos, filtros e entraves renitentes, empastes diáfanos de translucidez e opacidade, esses artistas expunham a impossibilidade de uma visão cristalina, de um olhar em projeção que atravessa sem rodeios a fronteira entre interior e exterior. Nessas pinturas, o espectador se torna incapaz de encontrar um locus para projetar seu olhar e, portanto, é privado também do regozijo de alcançar uma verdade de natureza qualquer, ou mesmo de ter acesso à realidade em sua forma objetiva ${ }^{115}$.

113 ALBERTI, op. cit., p. 94. Cabe ressaltar que no original Alberti utiliza, para designar "o que será pintado", a palavra historia, mobilizando, assim, uma categoria retórica. A historia não somente designava narrativa, mas também uma dimensão cênica para o acontecimento a ser visto. Veja-se: BELTING, op. cit., p. 119 e GRAFTON, Anthony. "Historia and Istoria: Alberti's Terminology in Context", in I Tatti Studies in the Italian Renaissance, Vol. 8 (1999), pp. 37-68.

114 STOICHITA, 2015, op. cit. O autor, em sua análise, estende a preocupação do olhar à literatura da época.

115 Cumpre mencionar que a prerrogativa de transparência da pintura italiana renascentista está intimamente relacionada a um modelo pictórico alicerçado na premissa de constatação, pois nela o plano pictural se abre a um espaço exterior que, muitas vezes, equivale ao espaço sagrado. Considere-se, por exemplo, a comparação entre a pintura italiana e a pintura do norte europeu tal como formulada por Norman Bryson: "Whereas the Albertian window of Italian painting opens effortlessly onto sacred spaces and transcendental truth, in the Northern context this access to the transcendent is exactly blocked and prevented: transcendental truth does not belong to the realm of the visible ; it cannot be simply pictured". Em: BRYSON, Norman. Looking at the Overlooked: Four essays on Still-life Painting. Londres: Reaktion Books, 1990, p. 150. 
Além disso, ainda que a arte italiana dos séculos XV e XVI encontrasse na janela uma metáfora e um modelo pictórico, ela raramente a apresentava enquanto tal (exceto através da moldura dos quadros ou da representação da arquitetura em sua função cenográfica, sobretudo em pinturas murais). Para que o olhar do espectador pudesse projetar-se para o exterior sem impedimentos, a janela deveria desaparecer. O que não exclui o fato de que ela deve operar em plano simbólico, carregando consigo a indicação tácita da posição do observador.

Foi sobretudo no século XIX que os artistas passaram a representar a janela com frequência em suas pinturas. Um motivo comum entre suas predileções era o da figura virada de costas olhando através das esquadrias ${ }^{116}$ - uma figura feminina, via de regra - a contemplar a paisagem desde um recinto interior. Com isso, não punham em evidência apenas o "olhar pela janela", mas o sujeito em seu olhar.

Tomemos, por exemplo, uma obra de Berthe Morrisot, Eugène Manet na Ilha de Wight, de 1875 (fig. 33). Nela, um homem -marido da artista e irmão do pintor Édouard Manet - é figurado no ato de observar através da janela. Um complicado sistema de filtros obstrui sua visão: cortinas entreabertas, vasos de flores, plantas, uma grade, as próprias treliças da janela, seu vidro translúcido. Por detrás de todos esses elementos, duas figuras femininas têm sua silhueta decomposta, entrecortada pelo ritmo do gradeado que a elas se antepõe. Essas figuras viram as costas ao observador no quadro e a nós mesmos enquanto observadores, voltando sua atenção a uma paisagem portuária que nos é quase inacessível - a não ser enquanto fragmentos dispersos e desordenados. Elas veem mais longe e melhor que nós, e mais e melhor que o observador no quadro.

A pintura do século XIX, em suma, já havia encontrado em suas formas inúmeras maneiras de problematizar a metáfora da pintura/janela - ou, se ainda a resguardava, o fazia somente para enfatizar seu estatuto de "janela lateral", de um orifício com a vista obliterada por folhas de árvore, fumaça ou por todos os outros resquícios de um turvo e fragmentário espaço urbano e industrial. E Picasso, como era de se supor, não estava alheio a essa transformação.

Uma singela pintura realizada na virada do século (fig. 34) (quando Picasso possuía tão somente dezenove anos) é prova vivaz disso. Ela mostra a janela vertical de seu ateliê

116 Outra vez, a arte holandesa poderia ser vista como contramodelo, uma vez que ela frequentemente representa janelas vistas da rua (Samuel van Hoogstraten, Gerard Dou, entre outros). 
por então, da qual só vemos o canto inferior direito: uma vista transversal, oblíqua, que nos dá acesso parcial ao movimento desordenado de uma rua estreita da antiga Barcelona, que, desde o último terço do século XIX, passava por processo intenso de urbanização e remodelagem, coroado pela reforma urbanística de Eixample. Essa janela se abre como uma fenda que nos convida a observar curiosamente o movimento da rua. Interessante é reparar que esse convite ao olhar é interceptado por uma silhueta escura que à direita, da varanda vizinha, nos observa na iminência do ato de olhar. Nessa pintura, a janela não é um signo metapictórico para refletir sobre o estatuto da representação: ela, antes, torna evidentes as situações de olhar e de ser olhado.

Tenho a impressão de que as janelas pintadas por Picasso em seu ateliê em Cannes em 1957 mais se parecem com aquela janelinha lateral dos idos de juventude em Barcelona ou mesmo com a janela através da qual observa o marido de Morrissot do que com a finestra de Alberti, a da perspectiva clássica. Como na pintura de Morrissot, elas abremse a uma vista parcialmente obstruída: podemos enxergar o mar, sempre obliterado por galhos de árvores e treliças que atravesssam o campo visual. Do lado de fora, entre o emaranhado de folhagem e gradeado, uma porção de pombos soltos se arranjam livremente no espaço, como se estivessem interagindo entre si randomicamente. Transparência, seleção e ordenamento estão fora de questão. De modo que sua abertura não nos remete a uma reflexão stricto sensu sobre a natureza da representação ou sobre a relação entre verdade e aparência, como defende Galassi, mas coloca em evidência o próprio olhar - ou, para ser exata, certa experiência do olhar - por trás da fenda que se abre. Um olhar intrincado e, sobretudo, curioso pelo movimento das coisas em sua configuração contingente, acidental. Esse, ao meu ver, é o elo entre Las Meninas e as pinturas de pombos: em ambos os casos, o que se põe em relevo é o olhar do espectador.

Mas espere. Seria, de fato, uma paisagem apenas acidental o que vemos através das janelas de Picasso? Galassi não se equivoca ao observar que o emaranhado de pombos em seu alinhamento trivial remete de forma paródica à infanta e a seu grupo, nem quando atenta para o fato de que, em muitas dessas pinturas, um pombo negro que mais se parece com um corvo espreita os pássaros brancos e encarna um olhar ameaçador que remete à figura do aposentador ${ }^{117}$. Na primeira delas, esse pássaro negro alça

117 GALASSI, op. cit., p. 143. No conteúdo educativo virtual do Museu Picasso Barcelona a mesma comparação é feita. Vide: http://www.blogmuseupicassobcn.org/2015/11/los-habitantesdel-museo-las-meninas/?lang=es, último acesso em 06 de março de 2019. 

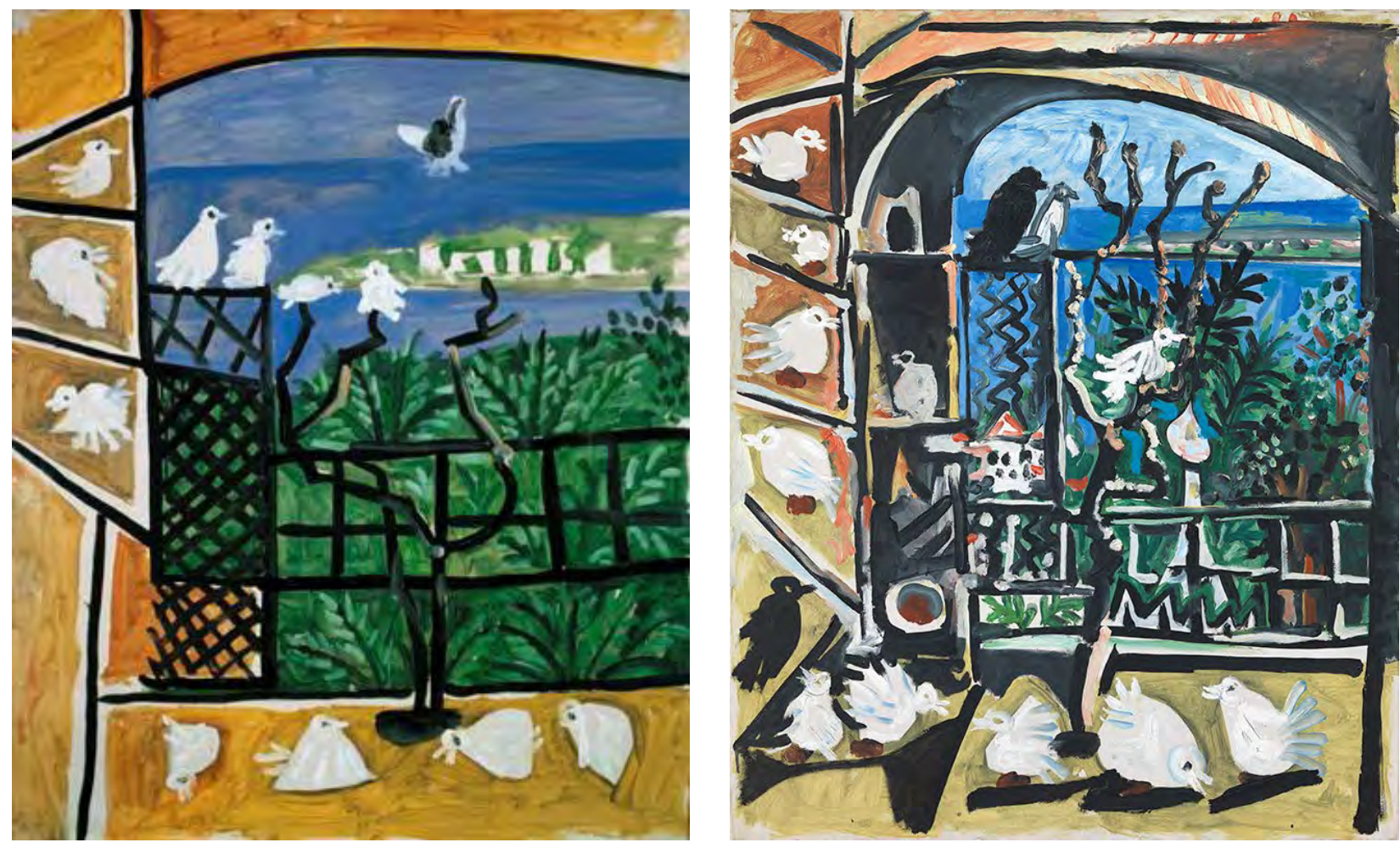

27 Los pichones

Cannes, 6 de setembro de 1957

Óleo sobre tela

$100 \times 81 \mathrm{~cm}$

Museu Picasso, Barcelona
28 Los pichones

Cannes, 6 de setembro de 1957

Óleo sobre tela

$100 \times 80 \mathrm{~cm}$

Museu Picasso, Barcelona 



29 Los pichones

30 Los pichones

Cannes, 7 de setembro de 1957

Óleo sobre tela

Cannes, 12 de setembro de 1957

Óleo sobre tela

$100 \times 80,5 \mathrm{~cm}$

$144 \times 113 \mathrm{~cm}$

Museu Picasso, Barcelona

Museu Picasso, Barcelona 


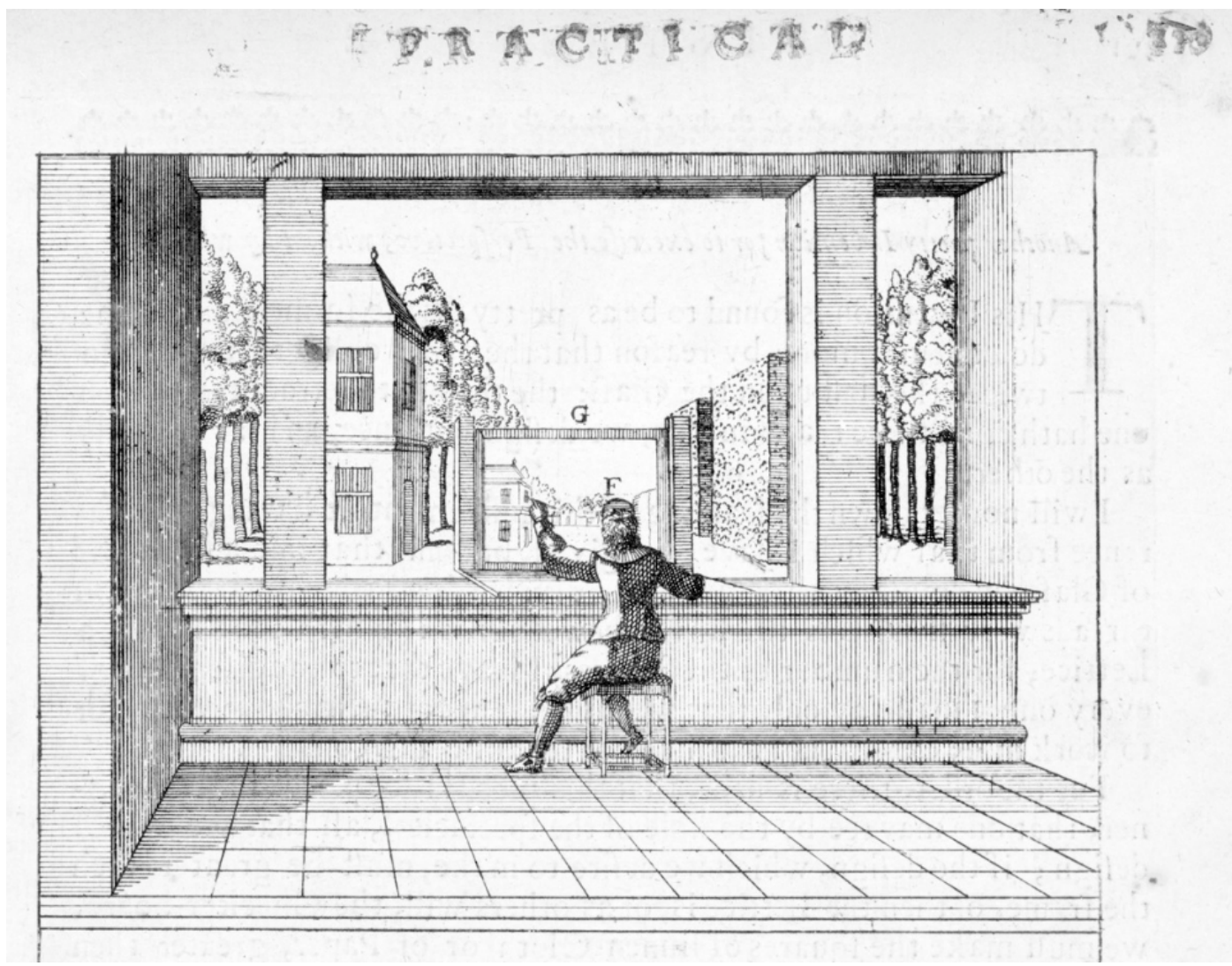

31 Jean Dubreuil.

Gravura em “A Perspectiva Prática”, 1642

Retirado da Biblioteca de livros raros e

manuscritos da Universidade de Yale.

32 Pablo Picasso

Rua Riera de Sant Joan

desde o estudio do artista, 1900

Óleo sobre tabla

$22 \times 13,8 \mathrm{~cm}$

Museu Picasso, Barcelona

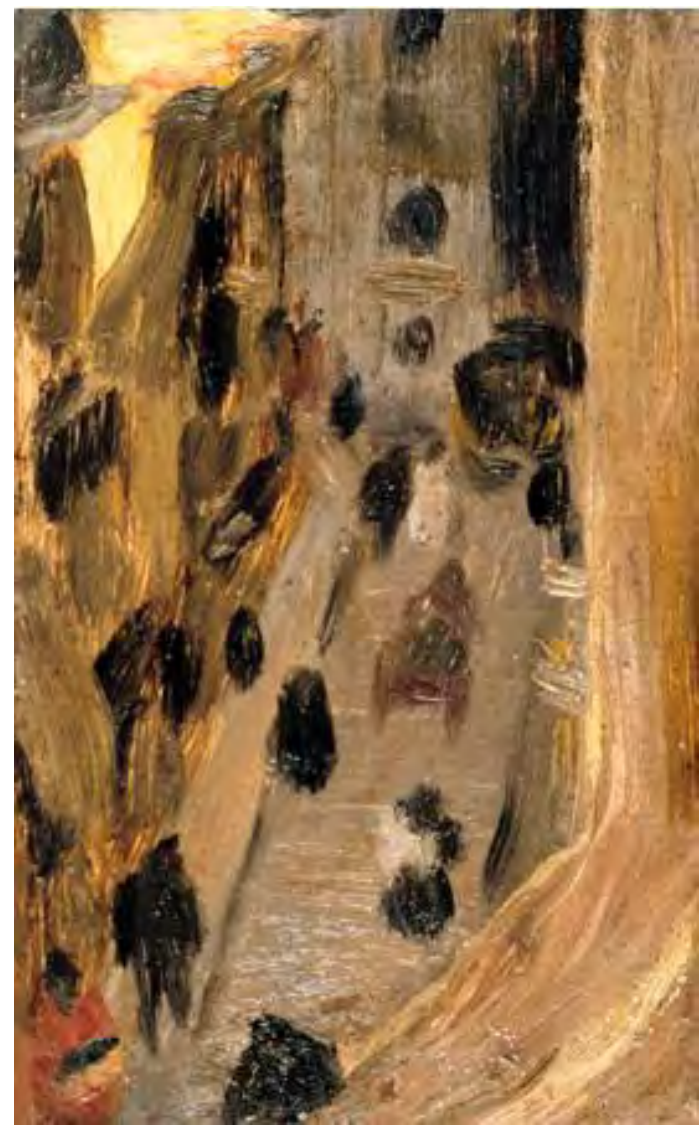



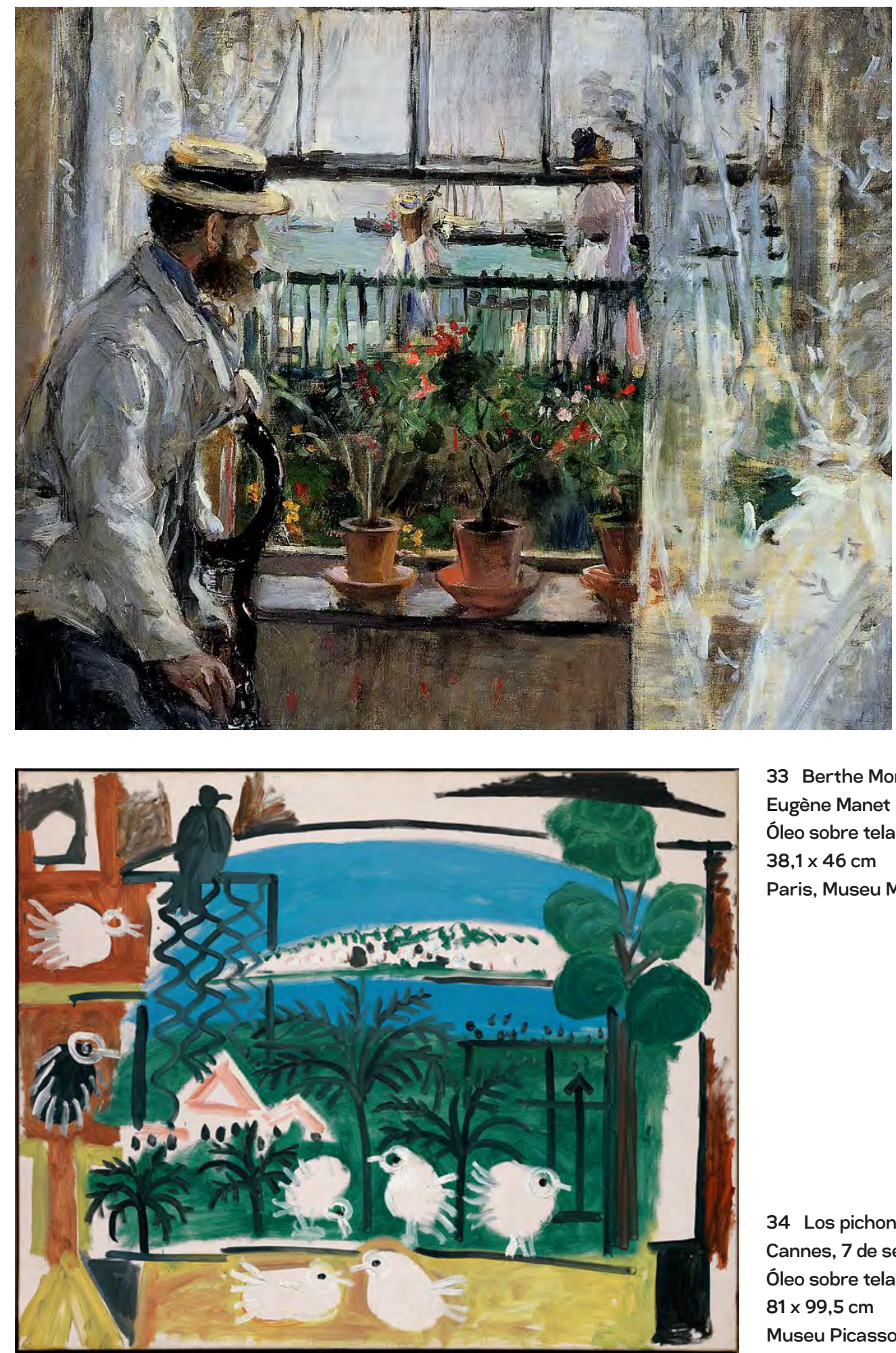

33 Berthe Morrissot

Eugène Manet na llha de Wight, 1874 Óleo sobre tela

$38,1 \times 46 \mathrm{~cm}$

Paris, Museu Marmottan Monet.

34 Los pichones

Cannes, 7 de septiembre de 1957

óleo sobre tela

$81 \times 99,5 \mathrm{~cm}$

Museu Picasso, Barcelona 
voo em meio ao céu azul, adejando as pombas brancas que picoteiam alimentos no solo. $\mathrm{Na}$ tela seguinte, ele (que é tão somente uma silhueta sombria) está postado no topo de uma estrutura de treliça, como se observasse atenta e ocultamente desde as alturas.

De pintura em pintura, entretanto, a sombra negra do corvo que espreita vai atenuando-se gradativamente (figs. 30-32). Apaziguada a ameaça, a pincelada voluptuosa e as cores vivas passam a prevalecer, dando total vazão à luminosidade reinante da paisagem mediterrânea, à calmaria e à normalidade. Até que na nona e última das pinturas de pombos vemos apenas alguns poucos pássaros brancos ciscando ou descansando no pombal (fig. 33). Pela janela, o azul do mar se destaca sem mais obstáculos.

O que resta é, portanto, uma paisagem sobrepujante que, não à toa, foi associada à influência que a recente morte de Henri Matisse teria exercido sobre Picasso ${ }^{\mathrm{II}}$. "Oui, il est mort. Il est mort, et moi, je continue son travail" ${ }^{119}$, teria dito Picasso certa vez, quando uma nova semelhança com os motivos do falecido rival fora detectada em seu trabalho.

Seria difícil crer que Picasso, ao retratar a voluptuosa e resplandescente paisagem mediterrânea que se vislumbrava da janela, nem sequer recordasse dos notórios e inevitáveis interiores iluminados de seu antigo colega e rival doze anos mais velho, cuja obra era - já nos anos 1950 e muito antes - frequentemente cotejada à sua ${ }^{120}$. Matisse que, aliás, não gostava de Velázquez ${ }^{\text {I2I }}$ e que em vida pintara tantas janelas (fig. 36) - até o ponto em que estas passaram a ser sua "marca registrada". Matisse que já havia retratado pombos em um batente, animais que ele não apenas pintava como também criava diligentemente (fig. 35); alguns, inclusive, presenteados ao próprio Picasso.

Cumpre assinalar que também Juan Antonio Ramírez compara os pombos e as meninas em primeiro plano, defendendo ainda que a janela do aposento pode ser vista como análoga à porta que abre o aposentador. Cf. RAMÍREZ, Juan Antonio. Picasso: El Mirón y la Duplicidad, Madrid: Alianza Editorial, 1994, p. 60.

118 GALASSI, 1996, op. cit., p. 166-167.

119 "Sim, ele morreu. Ele morreu e eu cotinuo seu trabalho", teria dito Picasso a Roland Penrose. Citado por STEINBERG, "Mulheres Argelinas de Picasso em Aberto", em Outros Critérios, op. cit., 174.

120 Muito foi escrito a respeito da emulação recíproca entre Matisse e Picasso. Elenco aqui BOIS, Yve-Alain, Matisse e Picasso, trad. Maria Alice A. de Sampaio Doria. São Paulo: Melhoramentos, 1999.

121 Tomo essa informação de BOIS, Yve-Alain. "Sobre Matisse: O cegamento", in Matisse: Imaginação, Vida e Erotismo, Sônia Salzstein (org.). São Paulo, Cosac Naify, 2009, p. 127. 
Não tenho a mais mínima intenção de refutar que as cores intensas, a pincelada ornamental e a frontalidade dessas pinturas constituem um apelo a Matisse: as ensolaradas janelas e os pombos de La Californie eram, sem dúvida, uma forma encontrada por Picasso de prestar-lhe homenagem, de encarregar-se de sua valiosa herança. Mas, para além disso, não seriam também uma provocação bem-humorada ao legado de Matisse?

E mais: qual é o fio condutor entre as pinturas de janela e o restante da série Las Meninas de Picasso? Retomemos, brevemente, a toada do conjunto. Até aqui, havíamos argumentado que Picasso, em sua série, explora a maneira como gestos, posturas e olhares se articulam para sugerir um fato qualquer. Que suas variações instigam um olhar curioso, capaz de encontrar na gramática disjuntiva de poses e expressões um extrato interpretativo. Não seriam as pinturas de janela um reforço ao convite a um olhar especulativo, que procura na banalidade do movimento dos pombos qualquer mancha que destoe, qualquer elemento capaz de atiçar e aguçar o apetite do olho?

Só que a solicitação, desta vez, tem um fundo paródico, ou, ao menos, é proferida em tom burlesco. Pois se a paisagem que a janela nos oferece é quimérica e exuberante, acolhedora e maravilhosamente bela, o olho curioso, contudo, está sempre em busca. Ele não se contenta com uma vista pura e simplesmente regozijante. Quer encontrar no emaranhado cotidiano de elementos que a janela dá a ver e no movimento ingênuo de pombos ciscando por comida um acorde dissonante. E se a tônica é identificar um ruído estridente que abale a harmonia cósmica de acordes agradáveis ao ouvido, nada mais apropriado que fazê-lo sob os auspícios de Matisse: artista conhecido, nas bocas do senso comum, pela imaginação paradisíaca e celebratória, que exalta a cada instante a "alegria de viver". $\mathrm{O}$ paladino da visão "pura", pintor das arcádias e das "songeries", que havia postulado "olhar a vida com os olhos de criança ${ }^{\mathrm{I22}}$ " numa época em que, como ele mesmo admitira, "o cinema, a publicidade e as grandes lojas nos impõem diariamente um fluxo de imagens prontas, que, em certa medida, são para a visão aquilo que o preconceito é para a inteligência ${ }^{123 "}$.

122 MATISSE, Henri. "É preciso olhar para a vida com os olhos de criança [1953]", in Escritos e reflexões sobre a arte, trad. Denisen Bottmann. São Paulo: Cosac Naify, 2007, p. 370. Citado por SALZSTEIN, Sônia. "Uma pintura de interiores", em Matisse: imaginação, erotismo e visão decorativa. São Paulo: Cosac Naify, 2009, pp. 149-166. Essa acepção epidérmica da obra de Matisse foi, sem dúvidas, estimulada pelas declarações do próprio artista, que frequentemente indicava seu apreço por valores como a "pureza", "simplicidade" ou "clareza". A estratégia do artista, no entanto, pode ser vista também como uma estratégia arguta de aproximar-se de seu público. Em seu texto, Salzstein discute a maneira como essas formulações são incorporadas e problematizadas nos interiores de Matisse, considerando a natureza ambígua dessa obra.

123 ibid. 
Não que o brado de escárnio direcionado ao colega francês estivesse livre de admiração. Além do mais, ele tampouco deixava de atingir a ele mesmo, Picasso. De certa forma, um quê de deboche já predominava desde as primeiras variações de Las Meninas, no traço "cartoonesco" e nas cores gritantes que dão tom às escrachadas expressões de assombro da infanta. Os rasgos ácidos e cortantes que impregnam a série - como em uma espécie de animação burlesca - não deixam incólume nem Velázquez, nem Matisse e tampouco a si; nem a infanta, nem os pombos e tampouco o observador. Até mesmo o olhar perscrutador instilado pelo artista pode lançar-se sobre seu próprio ponto cego: no frenesi de alcançar a recompensa desejada, o observador, amiúde, esbarra em falso numa aposta a fundo perdido. Os pombos são apenas pombos, e o dia segue ensolarado. E caso artista e observador, em sua perseverante curiosidade, insistirem na fé inabalável de sua empreitada, eles correm o risco, ainda assim, de tropeçar sobre si mesmos, dando a ver sua face exposta - isto é, a posição privilegiada de seu olhar. 

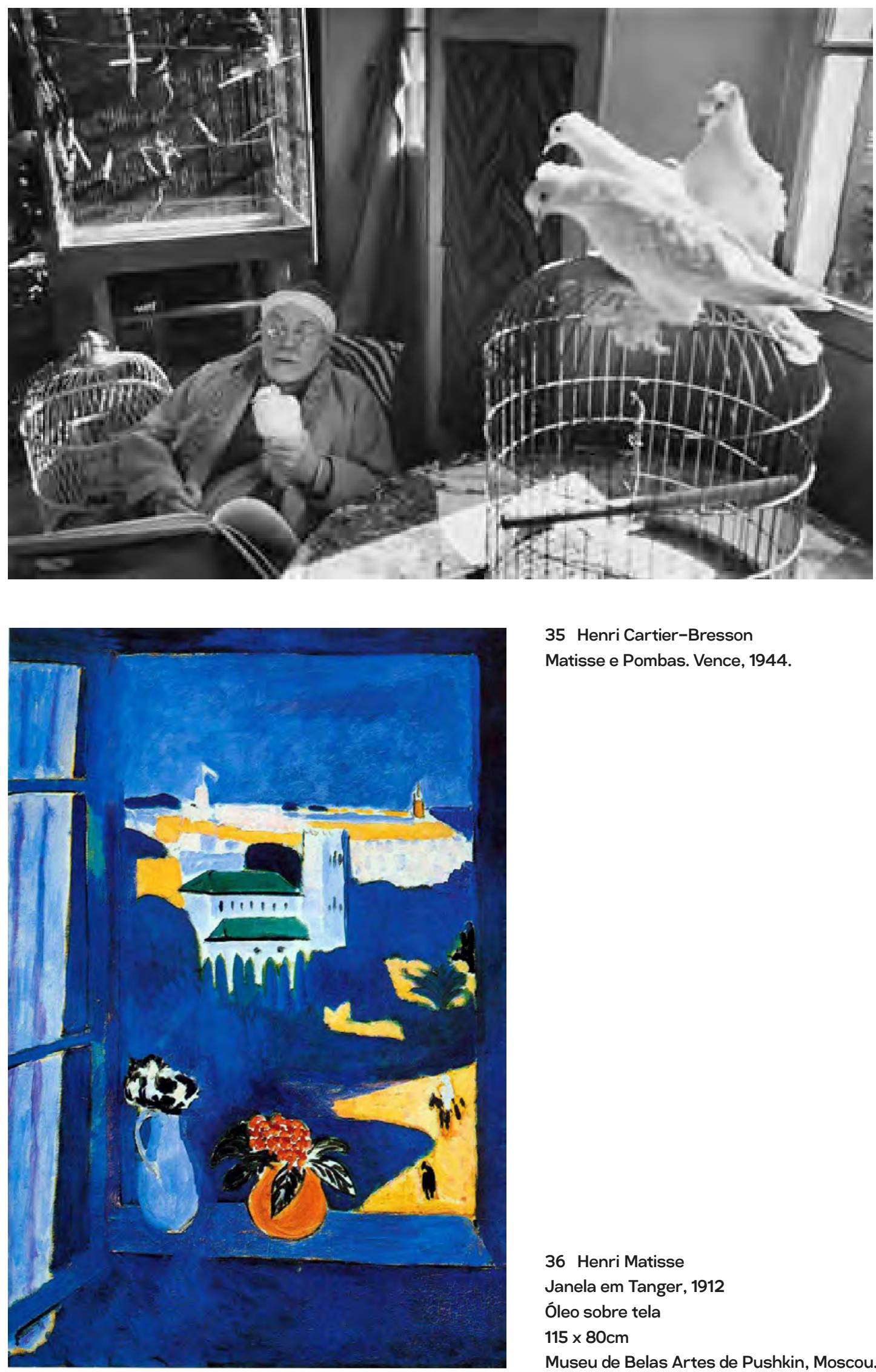

35 Henri Cartier-Bresson

Matisse e Pombas. Vence, 1944.

36 Henri Matisse

Janela em Tanger, 1912

Óleo sobre tela

$115 \times 80 \mathrm{~cm}$

Museu de Belas Artes de Pushkin, Moscou. 



\section{A SÉRIE: PARTE II}

São nove as pinturas de pombos realizadas entre os dias 06 e I2 de setembro de 1957. Eis que no próprio dia I2, de súbito, Picasso volta-se, outra vez, à figura da infanta no ato iminente de segurar o búcaro, aquele pequeno vaso oferecido pelas mãos de alguém fora de campo (fig. 37). Com essa pintura, nos despede das inspeções particularizadas de rosto e postura da princesa. A última das pinturas da menina havia sido um retrato em "primeiríssimo plano", no qual seu rosto destacava-se sobre um fundo escuro. Na pintura seguinte ao "intervalo" dos pombos, o mesmo fundo negro de outrora impõe à cena uma atmosfera obscura que contrasta com a paleta vivaz que há pouco imperava. É como se, após uma breve interrupção, voltássemos a enxergar aquilo que antes víamos, numa operação semelhante ao que, na linguagem cinematográfica, é tido por montagem em paralelo.

Caso nos propuséssemos a decompor a série em seções ou segmentos mais ou menos arbitrários somente para melhor compreender o ritmo e cadência impostos por Picasso, veríamos que após o interlúdio que demarca o fim da primeira parte de Las Meninas, Picasso inaugura o que parece ser uma segunda seção, na qual deixa momentaneamente de lado as pequenas sequências de pinturas relacionadas entre si tanto pelo "enfoque" quanto pelo "estilo" empregados, abandonando também o espírito analítico de decomposição que antes imperava.

Se na primeira parte da série o movimento sequencial encontrava nas poses e olhares das figuras os nódulos de seu encadeamento, agora é a espacialidade que dita a organização das figuras. As três variações que inauguram essa segunda parte funcionam como uma espécie de transição, já que ainda respeitam o fluxo do movimento que coordenava a série até então - o de ora aproximar-se, ora afastar-se dos detalhes, saltando de retratos individuais à representação do conjunto (figs. 42, 43). Mas esse movimento logo cessa: as cinco pinturas seguintes, realizadas entre 7 de setembro e o3 de outubro, são dedicadas à figuração da totalidade das personagens e sua disposição no aposento (figs. 44-48). Todas elas foram realizadas em telas de grandes dimensões e de proporções bastante semelhantes entre si (quatro delas medem I6I x I $29 \mathrm{~cm}$ e a outra, I30 x I6I,5 cm), empregadas tanto em sentido vertical como horizontal. A mudança de sentido, evidentemente, acarreta diferentes soluções: de composições mais constritas à espacialidade 
descompacta. Chama atenção a discrepância estilística entre essas pinturas: se antes, como havíamos dito, a tão celebrada capacidade de Picasso de transitar entre diferentes estilos obedecia a um padrão sequencial, agora ela aquiesce à lógica unitária. Todas essas pinturas em grande formato foram produzidas em continuidade e sem grandes intervalos entre si, mas nunca em um mesmo dia, como frequentemente acontecia anteriormente. E uma difere por completo da outra como notas de uma música atonal, cada uma obedecendo a normas de linguagem suigeneris.

Em meio à heterogeneidade gritante, contudo, certas características em comum saltam aos olhos. Nessas pinturas, mais do que nunca, as expressões "cartoonescas" e caricaturais das personagens passam a ditar o tom. Se num primeiro momento as variações eram dominadas por matizes sóbrias de branco, preto e cinza (remetendo a certo estilo associado a obras de grande porte e apelo dramático como Guernica), agora o ânimo burlesco surge à porta sem pedir licença. Nada mais justo: após a vil inspeção no rosto da infanta, Picasso abre mão de alcançar espessura psicológica para dar sentido a outra busca - a da densidade atmosférica e a do humor paródico.

Em grande parte dessas variações, a compressão espacial é tão acentuada que produz uma sensação de mordaz claustrofobia. Enquanto as pinturas em que a tela é empregada na horizontal são implacavelmente acachapantes, as variações em vertical são desconfortavelmente estreitas. Nas primeiras, a pressão atmosférica é tamanha que nos sentimos como naqueles dias carregados e de "teto baixo" em que a densidade do ar parece nos suplantar, ao passo que nas demais, a sensação de constrição é tão sufocante que temos a impressão de estar em um recipiente em que a pressão interna é tão avassaladora que tudo periga explodir.

Talvez o efeito mais notável dessa contenda seja o fato de que à medida que a esmagadora espacialidade da pintura passa a dominar, as figuras antes escrutadas individualmente se tornam mais e mais diminutas e "infantilizadas" em sua pequenez. A essa altura, periga soar banal e repetitivo afirmar que o apelo cada vez mais deflagrado ao universo infantil está despido de qualquer sentido genuíno, casto ou nostálgico. Que pelo contrário: a solidez bruta do espaço que recai sobre espaldas das pequenas figuras não pode senão romper a linha tênue que separa inocência de ameaça. Não é de se estranhar que nessas pinturas, Picasso tenha inserido inscrições simbólicas que remetem ao traço característico de Miró, artista que alude ao universo infantil não somente em termos idílicos, mas como o lugar mesmo do desejo e da perversidade. 
Tampouco é de se estranhar que, em meio ao ambiente asfixiante, a irrupção do aposentador passe a ser cada vez mais evidente. A porta da qual ele irrompe é o único ponto em que o espaço se abre ao exterior. O olho se sente impelido a alcançá-lo, em busca de uma saída do espaço altamente carregado. Ele é como um imã que atrai para si o olhar; é nele que se entrevê a cômica ameaça que pressentíamos ao longo da série. E a infanta, como era de se esperar, reluz em amarelo cintilante logo abaixo dele, emergindo como ponto destacado que reflete a luminosidade que vem da porta entreaberta.

Ao escrever sobre Las Meninas de Picasso pouco após sua execução, Roland Penrose reverenciou o humor "tipicamente espanhol" da série, fazendo das palavras de Baudelaire as suas: "os espanhóis são muito bem-dotados em matéria de cômico. Chegam rapidamente ao cruel, e suas fantasias mais grotescas contêm amiúde algo de sombrio. ${ }^{\mathrm{I} 4 \text { " }}$

Baudelaire, como se sabe, se referia às satúrnicas e atormentadas gravuras de Francisco de Goya, pelas quais Picasso nunca escondeu seu apreço. A comparação é precisa, embora os termos sejam em si bastante distintos. Ambos apelam a relações de contrastes violentos para aportar certo espírito provocativo e irreverente às suas séries, ainda que não haja qualquer elemento fantástico em Picasso, nada de contorções, rostos bestiais, caretas diabólicas ou hipérboles de imaginação - só para tomar algumas das características que Baudelaire tanto ressalta em Goya. No caso de Las Meninas de Picasso, talvez o contraste se dê de forma mais evidente quando a espacialidade constricta se alia aos traços caricaturais predominantes e à própria brutalidade infantil da linguagem empregada. Quanto mais jocosas as expressões e os rostos, mais sufocante e claustrofóbico o ambiente. "O sábio só ri ao tremer ${ }^{125}$ - eis o provérbio popular evocado por Baudelaire para abrir seus escritos sobre o cômico. A alegria, nos diz o poeta, é una, mas o riso só pode ser a expressão de um sentimento duplo e contraditório ${ }^{126}$.

124 A citação consta no livro de Penrose, em francês: "Les Espagnols sont três bien doués en fait de comique. Ils arrivent vite au cruel, et leurs fantasies les plus grotesques contiennent solvente quelque chose de sombre.". Cf. PENROSE, op. cit., p. 498-99. Para a versão em português que utilizo aqui, veja-se: BAUDELAIRE, Charles. Escritos sobre Arte, trad. Plínio Augusto Coelho. São Paulo: Hedra, 1998, p. 22.

125 Ibid., p. 10.
126 Ibid., p. 18.




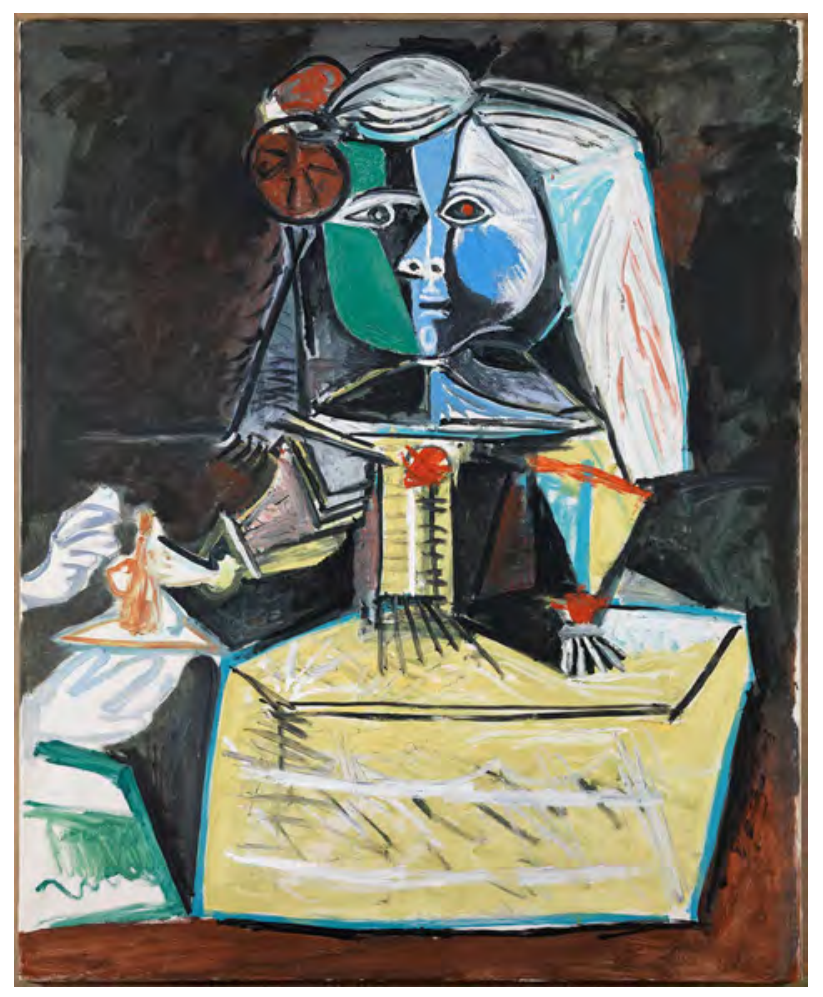

37 Las Meninas [infanta Margarita María]

Cannes, 14 de setembro de 1957

Óleo sobre tela

$100 \times 81 \mathrm{~cm}$

Museu Picasso, Barcelona.

38 Las Meninas

Cannes, 15 de setembro de 1957

óleo e carvão sobre tela.

$29 \times 161 \mathrm{~cm}$

Museu Picasso, Barcelona.




39 Las Meninas

Cannes, 15 de setembro de 1957

Óleo e carvão sobre tela

$129 \times 161 \mathrm{~cm}$

Museu Picasso, Barcelona.

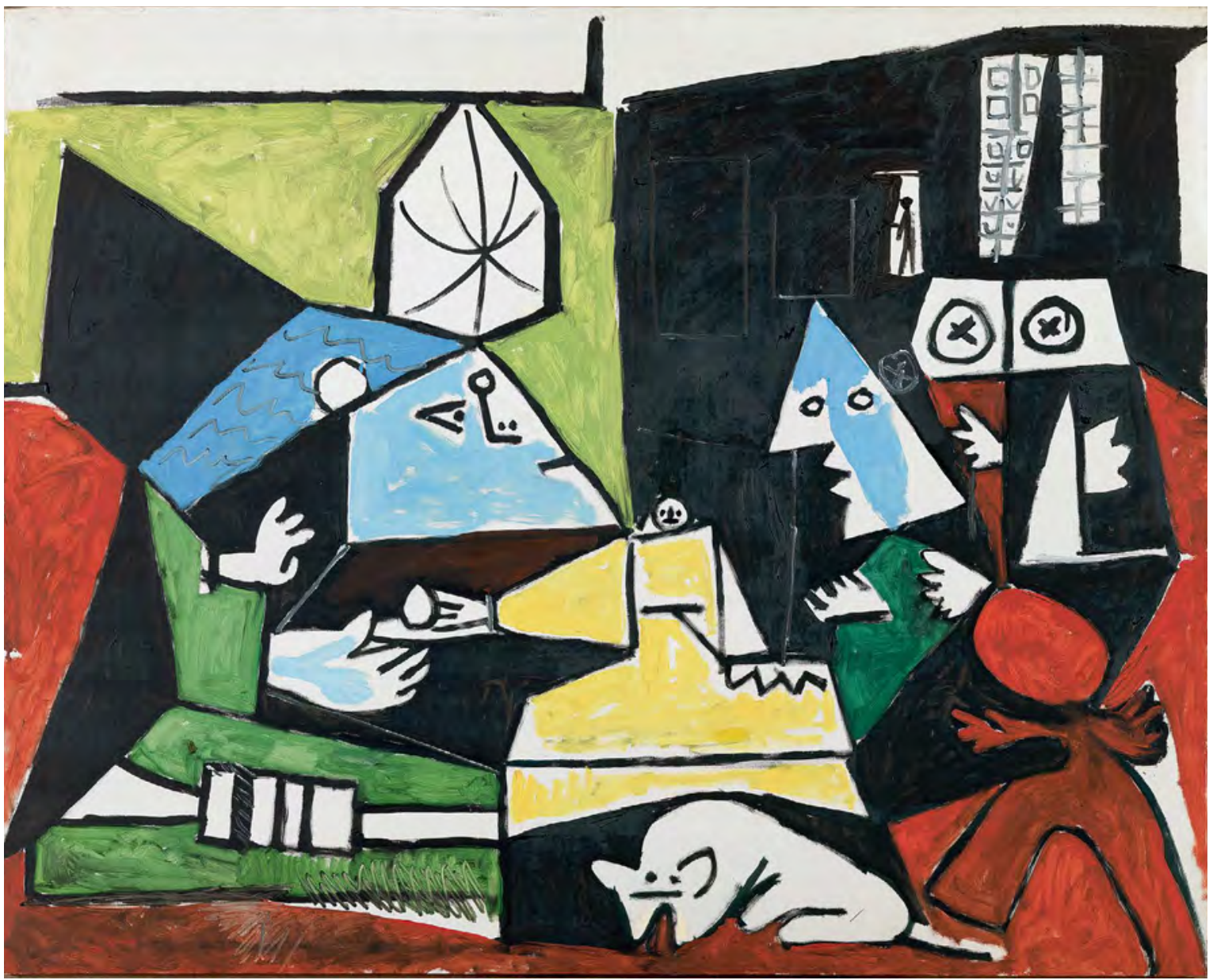




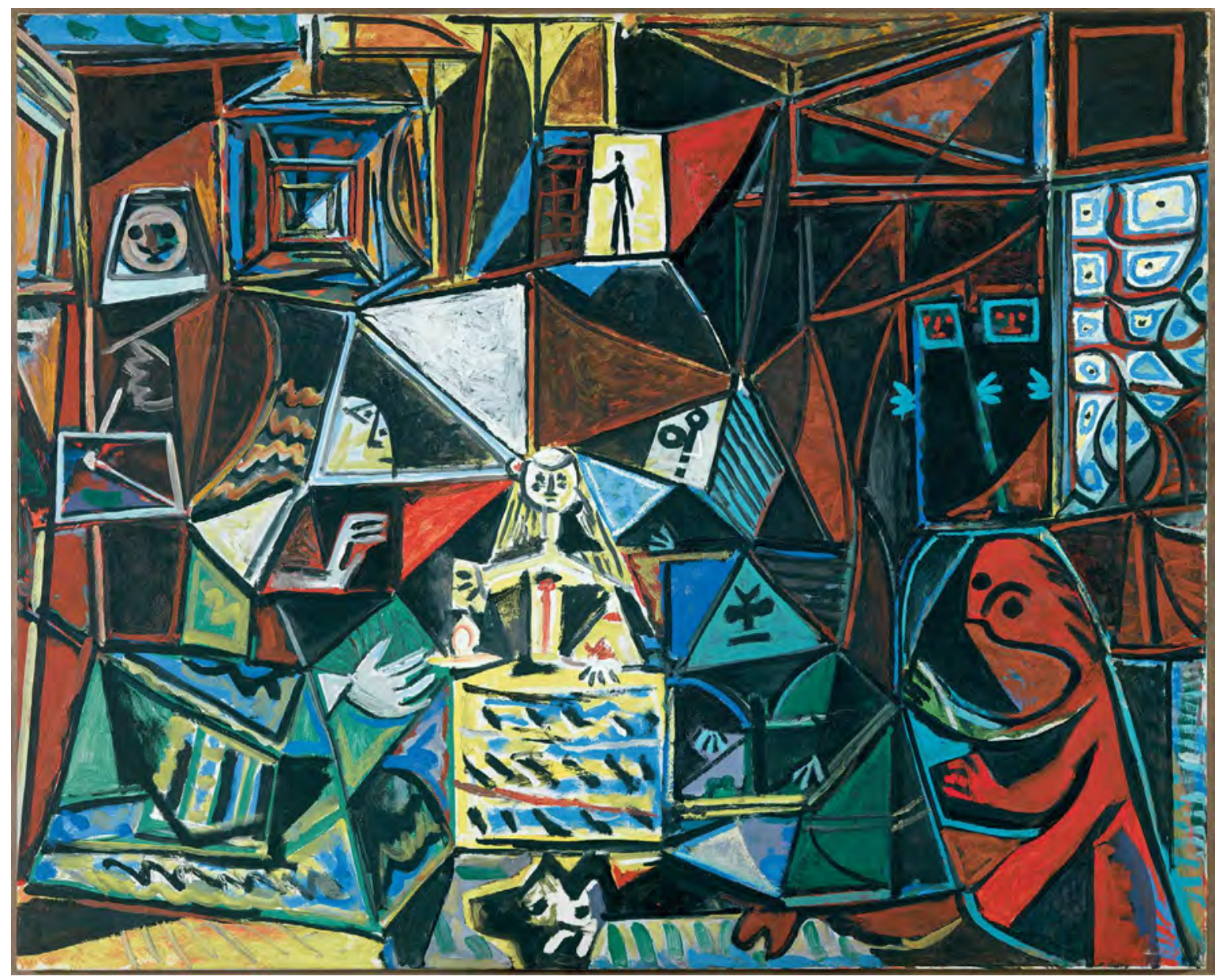

40 Las Meninas

Cannes, 17 de setembro de 1957

Óleo sobre tela

$30 \times 161,5 \mathrm{~cm}$

Museu Picasso, Barcelona. 


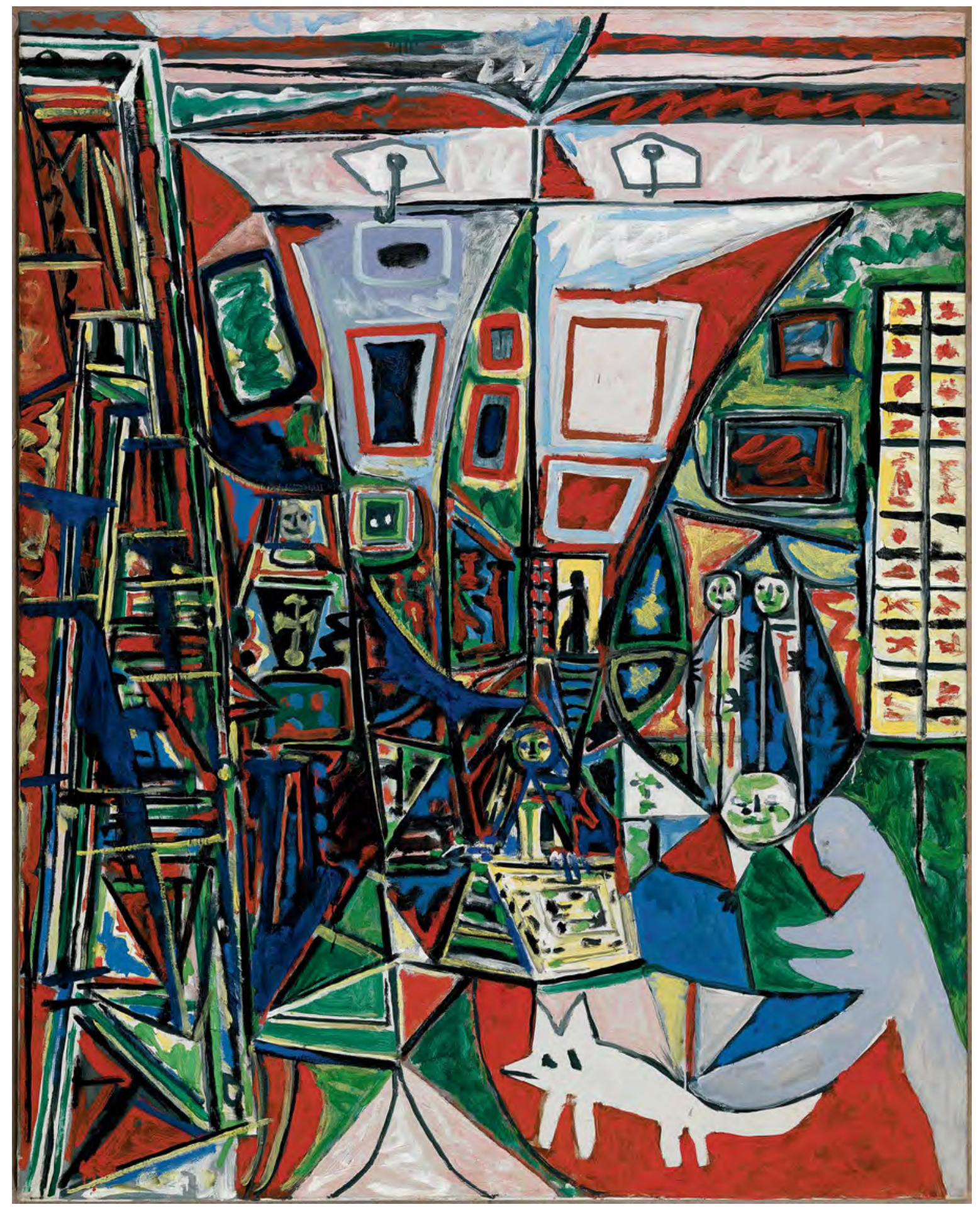

41 Las Meninas

Cannes, 19 de setembro de 1957

Óleo sobre tela

$161 \times 129 \mathrm{~cm}$

Museu Picasso, Barcelona 


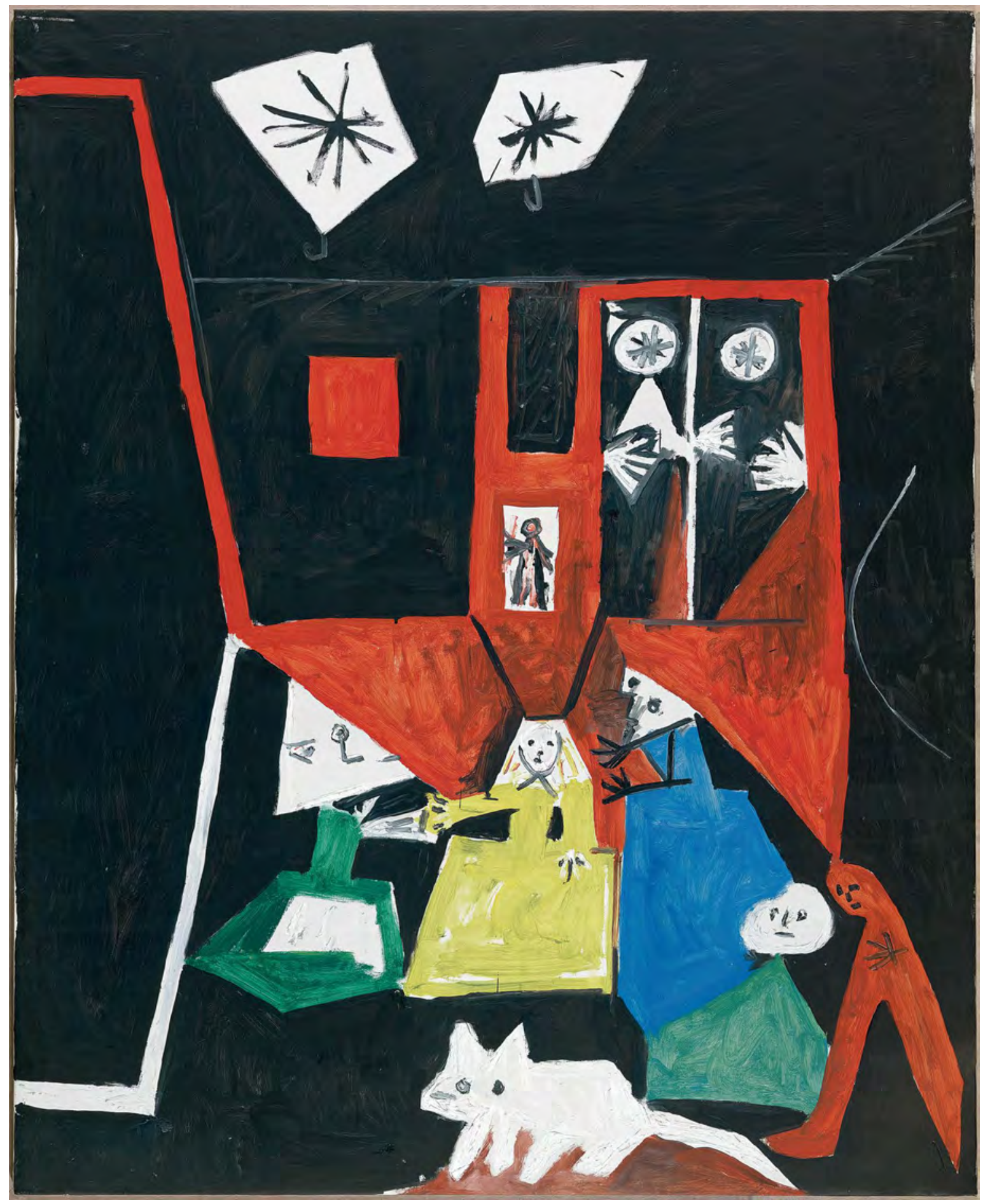

42 Las Meninas

Cannes, 2 de outubro de 1957

Óleo sobre tela

$161 \times 129 \mathrm{~cm}$

Museu Picasso, Barcelona 


\section{Uma questão de perspectiva}

As cinco pinturas que constituem essa "segunda parte" de Las Meninas - executadas entre I7 de setembro e 03 de outubro de I957, cerca de um mês após a realização da primeira variação - são, em certo sentido, o ponto culminate da série de Picasso. É nessas pinturas que toda a tensão que havia sido condensada no meticuloso trabalho de escrutínio aflora; é nelas que o que estava iminente eclode e se dá a ver. Elas demarcam uma espécie de clímax de um movimento que segue uma curva em parábola, insuflando-se até atingir o auge de tensão para, em seguida, desguarnecer-se, desatando ora ou outra nódulos de conflito para finalmente pender ao grau zero.

Após realizá-las, Picasso passa nada menos que vinte dias sem dedicar-se à sua versão de Las Meninas. É um intervalo grande, o maior desde o início da série. A partir de então, como se tivesse atingido uma espécie de apogeu, diminui o frêmito de trabalho, voltando-se cuidadosamente à árdua faina de decomposição e dissecção de figuras individualizadas, às variações regidas por um padrão ou unidade estilística particular.

Entre os dias nove e dez de outubro, portanto, Picasso dá início a uma nova jornada, produzindo uma sequência de pinturas que, como dissemos, remetem àquilo que vinha sendo feito nas primeiras variações. Voltando a telas de formato mediano, retrata as damas de companhia da infanta em seus gestos e posturas particulares. A primeira das figuras perscrutadas é a criada à direita da princesa, Isabel de Velázco, que faz sua aparição individual pela primeira vez (fig. 43). Ato contínuo, parte mais uma vez para a cena familiar de María Augustina em seu gesto de oferecer o pequeno búcaro à infanta (fig. 44). E se esse motivo havia sido tratado inúmeras vezes anteriormente, agora ele é mostrado de uma perspectiva distinta, pouco explorada até então: não mais como um detalhe expressivo, como um corte que potencializa o efeito dramático da postura da infanta, mas como um gesto em si, dotado de significação. E de agora em diante, não é mais a infanta a figura focalizada, mas sua dama de companhia - aquela que outrora configurava o fora de campo essencial da cena.

O espectador atento, satisfeito em identificar o paralelo entre isso que vê e aquilo que antes vira, logo deduzirá dessas variações a mesma sensação de movimento paralisado e de iminência de uma ação interrompida presente nas primeiras sequências da série. A comparação procede, mas certos detalhes revelam ainda uma outra camada de significação. Se antes os movimentos congelados produziam a sensação de suspensão narrativa, agora eles são capazes de produzir uma sensação quase oposta. Parecem querer 
exprimir qualquer coisa, como se fossem ao mesmo tempo a consequência e o prenúncio de um acontecimento. Tão conspícuo é seu tom enunciativo que Galassi chegar a ver nessas variações uma espécie de anunciação bizarra ${ }^{127}$.

Galassi tem razão. De fato, o gesto de mãos, o rosto perfilado, o olhar devoto e a posição corporal em genuflexão da dama de companhia - explorados insistentemente da variação 36 à 39 - logo remetem às tradicionais imagens do Arcanjo Gabriel e da Virgem Maria na pintura italiana. De modo análogo, as próximas variações dedicadas ao estudo do anão Nicolás Perusato remetem também à semântica de gestos tradicionalmente empregada na representação da anunciação. De maneira um tanto insólita, é bem verdade: na primeira delas (fig. 45) a postura do anão é completamente transfigurada e plasma-se na imagem de um garoto tocando piano, com as mãos erguidas em um movimento ao mesmo tempo expressivo e suspenso que curiosamente faz recordar determinadas representações florentinas da anunciação que apresentam Maria sentada em seu quarto no preciso momento em que recebe a visita do Anjo Gabriel. (fig. 46 ).

Somente como exercício livre de comparação, coloquemos as variações de número 38 e 4 I lado a lado (figs. 47, 48) e, em seguida, comparemo-nas com a célebre Anunciação de Sandro Botticelli (I 489-I 490) (fig. 49). As ressonâncias, ainda que fortuitas, saltam aos olhos: a inclinação dos corpos, a posição das mãos, as expressões, a direção do olhar, tudo parece convergir. Levemos o exercício adiante e aproximemos as variações 39 e 40 (figs. 5I e 45), realizadas em sequência, e cotejemo-nas com a Anunciação(I584) de Andrea del Sarto, pertencente à Galleria Palatina, em Florença (fig. 50). Ainda que a serva e o menino ao piano pertençam a um universo completamente alheio ao das imagens religiosas dos séculos XV e XVI, certos elementos repercutem estranhamente uns nos outros: o oferecimento do búcaro faz lembrar o ramo de lírios que o Anjo Gabriel entrega à Virgem, o livro aberto entre as figuras encontra afinidade com a partitura ao piano e o vaso de flores da pintura italiana ecoa naquele da imagem de Picasso.

Ora, tanto o vaso de flores quanto o livro aberto - como é bem sabido - são elementos iconográficos tradicionalmente empregados na significação visual de 
"Maria anunciada" ${ }^{28}$, e funcionam, na pintura italiana, como equivalentes da entrada do Anjo Gabriel e da pomba do Espírito Santo nos aposentos da virgem ${ }^{129}$.

Além disso, outro motivo iconográfico amiúde relacionado à representação da "Virgem anunciada" parece reverberar nas pinturas de Picasso, ainda que de forma longínqua. Trata-se da porta semiclausa, simultaneamente aberta e fechada. Ela está presente, ao menos remissivamente, nas variações 36,38 e 39, nas quais uma linha ortogonal traçada por trás da cabeça da dama de companhia opera como sugestão de divisão do comodo. E a iluminação nessas pinturas faz do limiar insinuado uma evidência ainda mais palpável: da direita para a esquerda, vemos um feixe luz esbranquiçada partindo dos fundos, como se emanasse de uma abertura em profundidade apenas intuída. Na variação 37, ela aparece de forma explícita: por trás de Maria Agustina Sarmiento e da infanta, vemos uma abertura retangular delineada em linhas pretas, da qual jorra um feixe de luz esbranquiçada e difusa que incide diretamente na cabeça da dama de companhia.

É difícil não ver a série com outros olhos a partir do momento em que se nota a presença remota da porta-semiclausa incrustrada na atmosfera difusa das "bizarras anunciações" depuradas dos gestos da infanta e de sua dama de companhia. É como se elas ressignificassem, em retrospecto, o conjunto de variações em grande formato que eu havia definido como o apogeu da série - em um movimento particular de intensificar e desatar nódulos de tensão. Permito-me esboçar um sucinto e limitado apanhado sobre o argumento de Daniel Arrasse a respeito da anunciação italiana para buscar compreender como isso ocorre.

128 O termo "Marie Annoncée" é empregado por ARASSE, Daniel. L'Annonciation Italienne: une histoire de perspective. Paris, Éditions Hazan, 2010, p. 64. Sobre a "virgem anunciada", veja-se também VON HOR SKAFF, Susan. "The Virgin Annunciate in Italian Art of the Late Middle Ages and Renaissance", in College Literature, Vol. 29, No. 3, Literature and the Visual Arts (Summer, 2002), pp. 109-123.

129 Sua invenção, segundo Daniel Arasse, pode-se atribui a Duccio. Cf. ARASSE, op. cit., p. 64. 
43 Las Meninas

[María Agustina Sarmiento]

Cannes, 9 de outubro de 1957

óleo sobre tela

$65 \times 54 \mathrm{~cm}$

Museu Picasso, Barcelona

44 Las Meninas

[María Agustina Sarmiento e infanta Margarita María]

Cannes, 10 de outubro de 1957

Óleo sobre tela

$92 \times 73 \mathrm{~cm}$

Museu Picasso, Barcelona
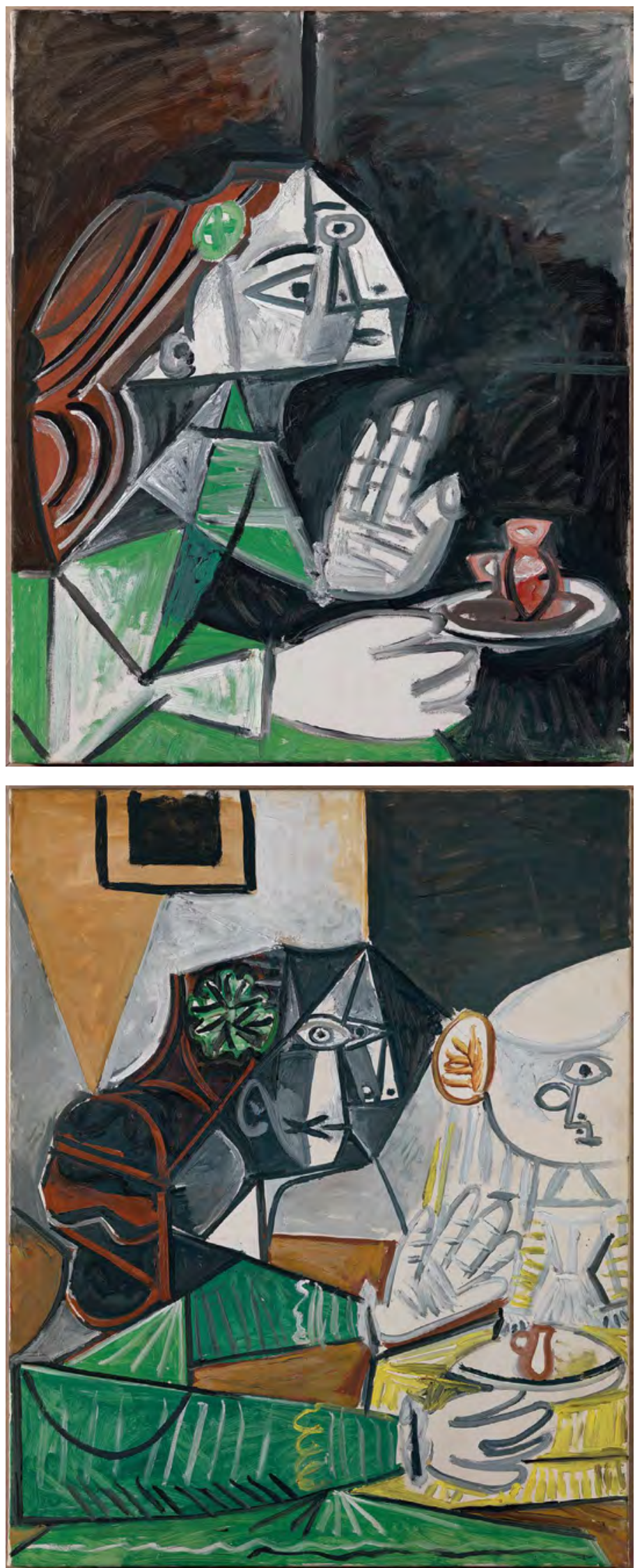

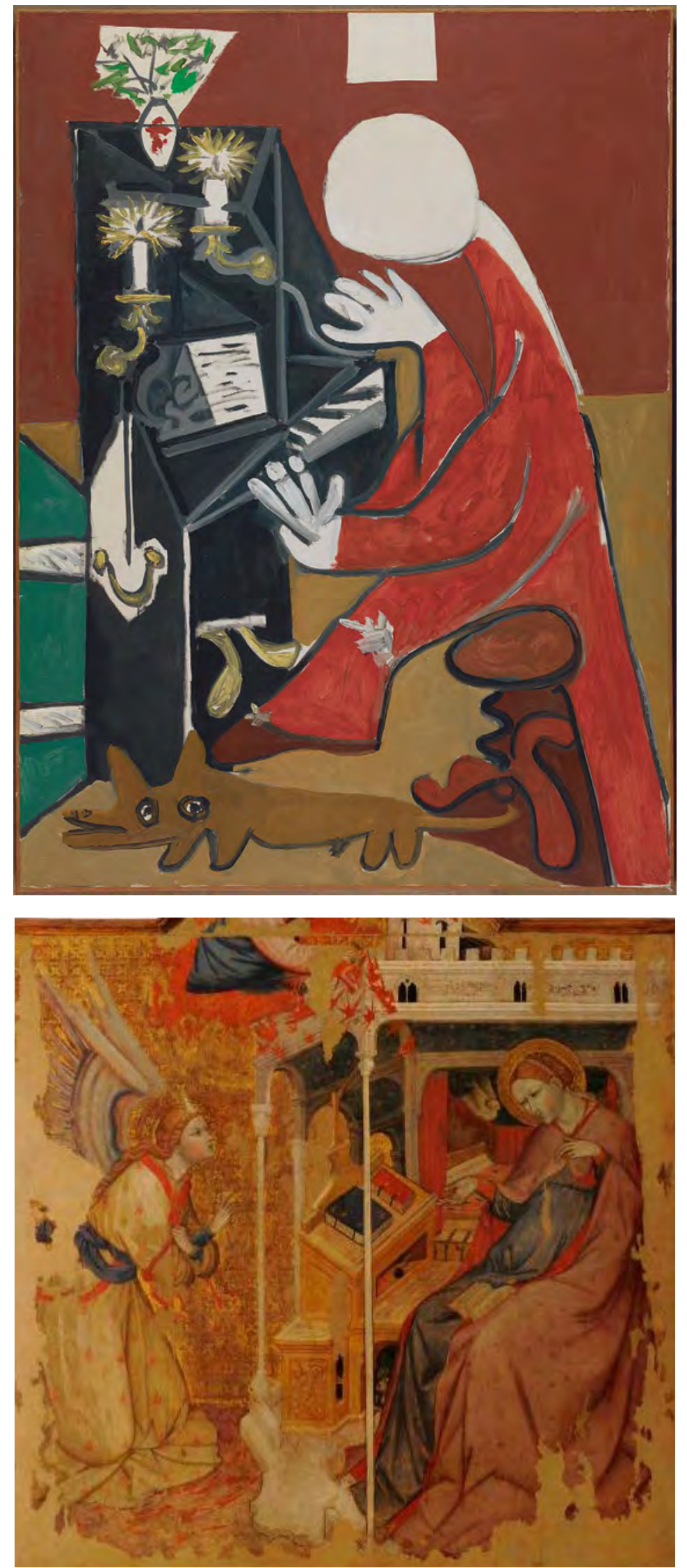

45 El piano

Cannes, 17 de outubro de 1957

Óleo sobre tela

$129,5 \times 96,5 \mathrm{~cm}$

Museu Picasso, Barcelona

46 Carlo da Camerino

Anunciação, c. 1395

Têmpera sobre madeira $159,5 \times 185 \mathrm{~cm}$

Galeria Nacional, Urbino. 

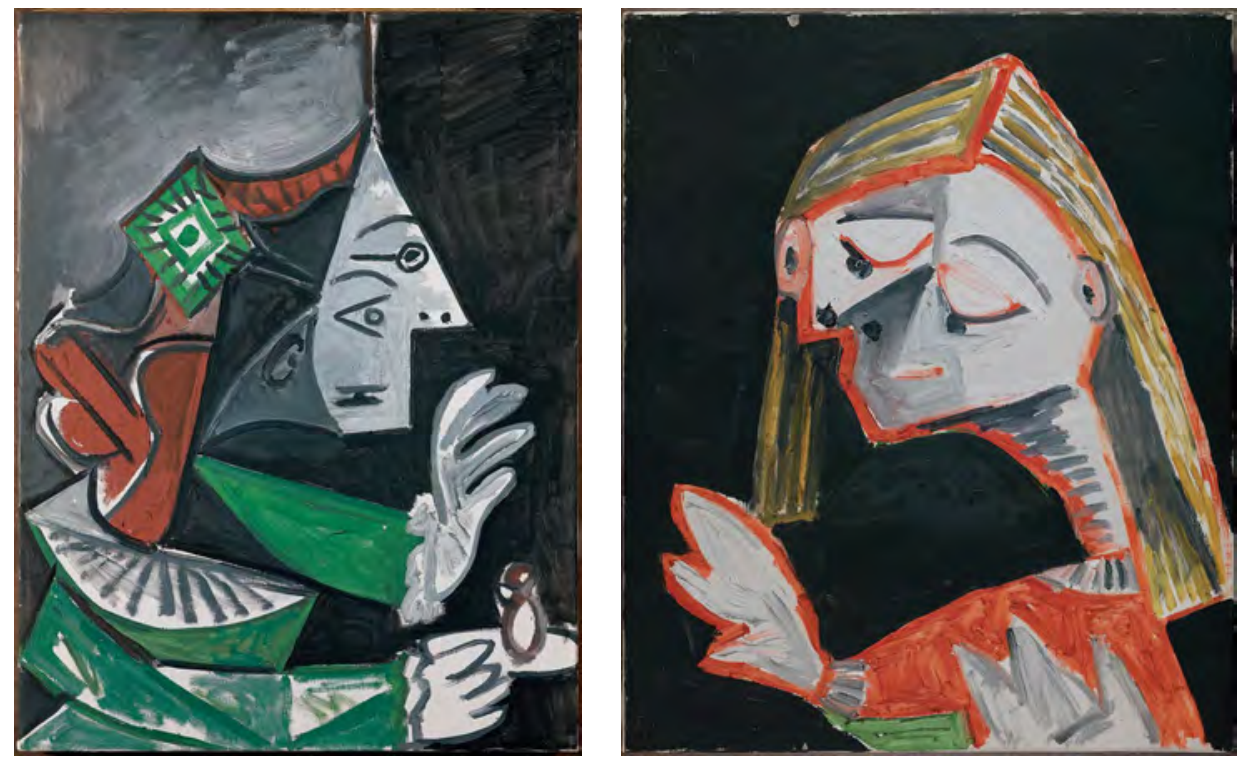

47 Las Meninas

[María Agustina Sarmiento]

Cannes, 10 de outubro de 1957

Óleo sobre tela

$73 \times 55 \mathrm{~cm}$

Museu Picasso, Barcelona

48 Las Meninas

[Nicolasito Pertusato]

Cannes, 24 de outobro de 1957

Óleo sobre tela

$61 \times 50 \mathrm{~cm}$

Museu Picasso, Barcelona

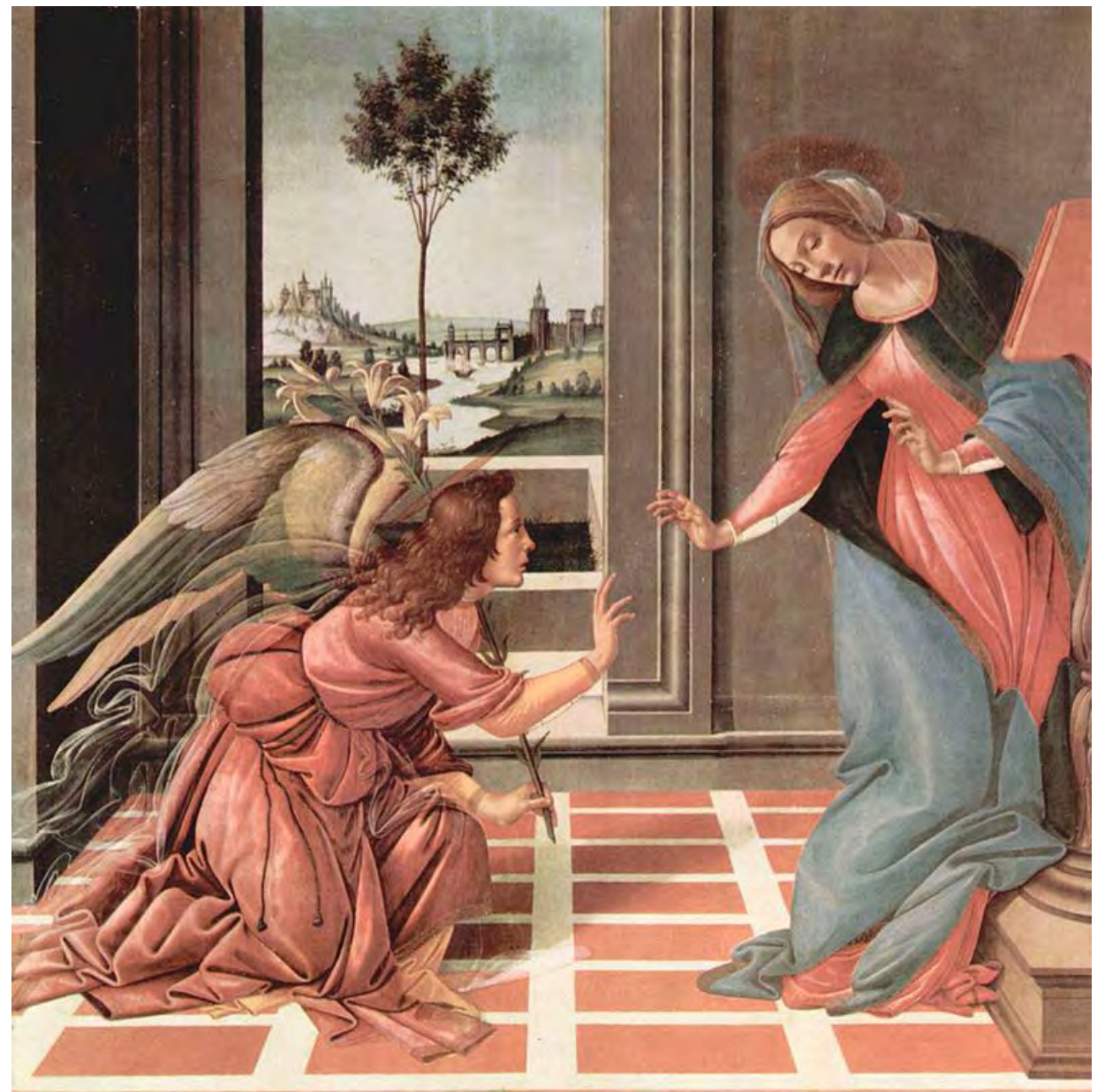

49 Sandro Botticelli Anunciação, 1489-90

Têmpera sobre madeira $240 \times 235 \mathrm{~cm}$

Museu de Artes e Ofícios, Florença 



50 Andrea del Sarto

Anunciação, 1528

Óleo sobre tela

$96 \times 189 \mathrm{~cm}$

Galeria Palatina, Florença

51 Las Meninas [María Agustina Sarmiento] Cannes, 10 de octubre de 1957

Óleo sobre tela

$115 \times 89 \mathrm{~cm}$

Museu Picasso, Barcelona 
Em seu minucioso estudo sobre a anunciação italiana entre os séculos XV e XVII, Arasse postula a tese de que há uma relação de afinidade entre o tema da anunciação no Renascimento e a instauração do modelo perspectivo (monocular) no século XV. Para definir a natureza dessa afinidade, volta-se a murais e altares de Masaccio e seus discípulos em Florença no Quattrocento, nos quais identifica uma inovação do sistema espacial de organização e repartição dos elementos iconográficos tradicionais da anunciação - o vaso de flores, a porta entreaberta e o livro ${ }^{130}$.

Esse novo sistema de "iconografia espacial" se articula a partir de dois eixos: o primeiro deles, paralelo ao plano de representação, coloca as figuras do Anjo Gabriel e de Maria face a face em porções opostas da tela - entre eles, o livro e o vaso de flores, ou os lírios que o anjo entrega à Virgem. O segundo, perpendicular a esse mesmo plano, faz as fugas da arquitetura convergirem na porta semiaberta. O entrecruzamento desses dois planos axiais comporta um corolário importante: instaurando uma distância entre a Virgem e o anjo, valoriza, no centro da imagem, a zona que separa as figuras - e transforma esse espaço entre-deux em um lugar verdadeiro, que participa da economia geral da imagem (fig. 52).

À disposição bipartite e ao ritmo binário das anunciações à maneira antiga, os artistas italianos contrapõem uma composição tripartite, em cujo centro se localiza uma abertura espacial que, segundo o autor, tem uma função decisiva na história pictural do tema. A partir de então, muitas são as imagens que dispõem Maria e o anjo em porções opostas do campo de representação, separados pela porta semiclaustra. Essa abertura é, precisamente, uma fenda na unidade oclusa da arquitetura virginal; é dela que irrompe a luminosidade divina que indica a encarnação. Ela é, em outras palavras, uma abertura através da qual penetra a presença não figurada do divino ${ }^{131}$.

Não seriam pressões axiais similares as que operam em grande parte - se não em todas - as pinturas em grande formato de Las Meninas de Picasso?

As coincidências entre o modelo descrito por Arrasse e essas pinturas são, ao menos, conspícuas: em quase todas essas variações, o espaço é dividido entre um eixo paralelo ao plano no qual se dispõem as figuras e um eixo perpendicular ao plano pictórico que o divide em dois. Esse eixo perpendicular, em uma delas, é inclusive demarcado

130 ARASSE, op. cit., p. 25.

131 Ibid. 


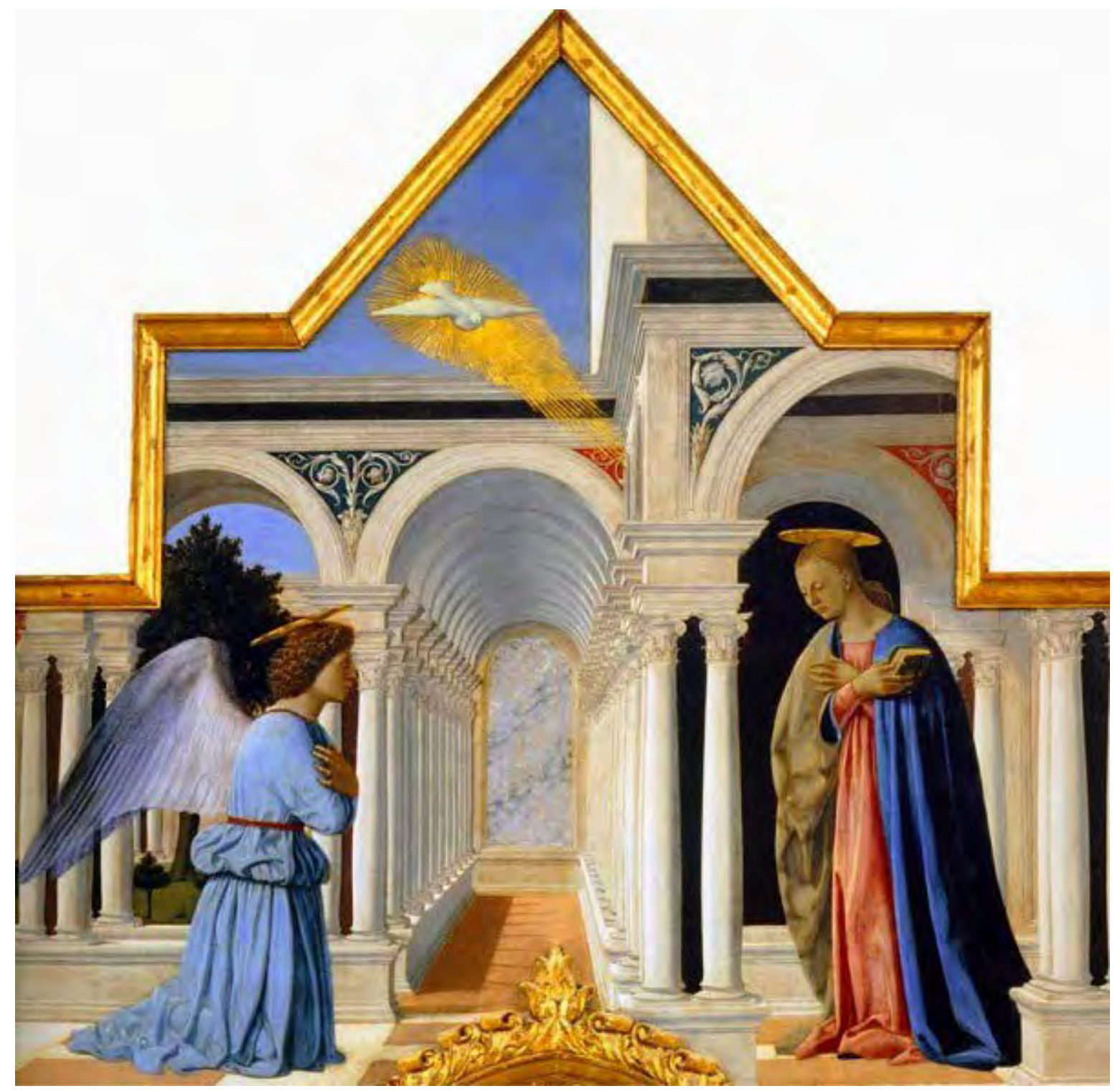

52 Piero dela Francesa.

Políptico de Pérouse (Anunciação), 1470

Têmpera sobre madeira

$122 \times 194 \mathrm{~cm}$

Galeria Nacional de Umbria, Pérouse. 
por uma proeminente linha reta traçada em preto, que dificilmente passa desapercebida ao observador (fig.50). Em outras pinturas, as duas lâmpadas no teto - que na obra de Velázquez convergiam em perspectiva para formar o eixo que divide o aposento em dois - são dispostas horizontalmente em uma porção e outra da tela, intensificando a sensação de clivagem espacial. Mas a coincidência mais ostensiva talvez seja a própria presença, no eixo perpendicular da pintura, da porta pela qual irradia uma luz intensa e penetrante - da abertura que, no modelo proposto por Arrasse, é valorizada pela construção perspectiva para figurar a irrupção do sobrenatural no espaço da representação. Na primeira das variações de Picasso, é curioso que justamente dessa porta centralizada irradie um feixe de luz esbranquiçada que incide diretamente no búcaro que a dama de companhia oferece à infanta, como se valorizasse precisamente esse gesto como foco de tensão dramática. O mesmo gesto que, ato contínuo, será explorado reiteradamente pelo artista; gesto este retomado nas últimas variações - aquelas mesmas em que Galassi identificou a tal "bizarra anunciação".

Evidentemente, ao traçar esse paralelo não almejo insinuar que a série de Picasso seja alusiva de maneira explícita ou premeditada ao motivo da anunciação ${ }^{132}$. Pretendo somente sinalizar que a estrutura compositiva empregada pelo artista é altamente sugestiva do espaço como uma forma ${ }^{133}$ capaz de insinuar irrupção ou penetração sem que isso seja figurado de forma literal. Mas se nas anunciações é a presença divina que irrompe no recinto de Maria, na série de Picasso é o aposentador que anuncia sua intrusão nos aposentos da infanta.

132 Cabe sinalizar, ainda assim, que Picasso sentia um conhecido apreço pelos "primitivos italianos" e que tal afinidade, conforme demonstra Pepe Karmel, pode inclusive ter desempenhado papel decisivo na invenção do cubismo. Cf KARMEL, Pepe. Picasso and the invention of cubism. New Haven: Yale University Press, 2003, pp. 14-15.

133 Me alinho a Daniel Arrasse quando uso Forma, aqui, com vista no sentido que Pierre Francastel dá ao termo:"'"La Forme [...] n'appartient pas au niveau des éléments et des contennus, mais au niveau des principes, c'est à dire, des estructures. Elle s'identifie avec le Schème d'organization qui suggere l'assemblage des élements." Cf. FRANCASTEL, Pierre. "Signification et Figuration", in Realité figurative. Élements Structurels de sociologie de l'art, Paris: 1963, pp. 97-128, citado em: ARASSE, op. cit., p. 51. Cabe ressaltar que não me refiro à discussão da perspectiva enquanto "forma simbólica", que remonta a Erwin Panofsky (que, por sua vez, toma o termo emprestado de Ernst Cassirrer). No caso do estudo de Panofsky, a perspectiva é tomada enquanto "forma simbólica" para a compreensão da historicidade da experiência de dessacralização renascentista. Veja-se: PANOFSKY, Erwin. A perspectiva como forma simbólica, trad. Elisabete Nunes. São Paulo: Edições 70, 1993. Para um estudo comparativo entre a espacialidade na visão de Panofsky e Pierre Francastel, veja-se.: CAMPOS, Jorge Lucio. Do simbólico ao virtual: a representação do espaço em Panofsky e Francastel. São Paulo: Perspectiva; Rio de Janeiro: Universidade do Estado do Rio de Janeiro, 1990. 
Não que a estrutura espacial cindida das variações dedicadas ao conjunto de Las Meninas de Picasso tenha passado desapercebida pela fortuna crítica sobre a série. Sua emergência, entretanto, foi rapidamente associada à retomada de modelos e pinturas anteriores do próprio artista - em específico, às célebres Ateliê e Pintor e Modelo, de I927I928, ambas hoje no Museu de Arte Moderna dos Estados Unidos ${ }^{134}$ (figs. 53, 54). Nessas pinturas, artista, modelo e tela são representados num panorama lateral que esquematiza conceitual e espacialmente o ateliê como espaço de produção. Não soaria estranho que para sua versão de Las Meninas de Velázquez - obra culminante sobre os "paradoxos da representação" - Picasso se voltasse às suas próprias obras onde o ateliê é evocado como espaço por antonomásia da representação pictórica (aquelas que notavelmente tematizaram a figuração e a abstração como linguagem, os materiais, métodos e elementos estruturais da pintura ${ }^{135}$ ).

Essa associação, embora tentadora em um primeiro momento, merece algumas ressalvas: a começar pelo fato de que se, por um lado, a representação do ateliê enquanto espaço de produção desempenha papel fundamental ao longo de toda obra de Picasso, é patente que a figura do pintor tenha sido excluída da maior parte das pinturas da série Las Meninas. Se o artista retém algo da dimensão metapictórica presente tanto em suas anteriores Ateliê e Pintor e Modelo quanto na própria obra de Velázquez, ela é repaginada somente de forma parcial e indireta, jamais como um sistema fechado que coloca em evidência seus próprios termos estruturais.

Entretanto, constatar que a dimensão metapictórica não desempenha um papel essencial nas variações de Las Meninas de Picasso enquanto tema não exclui o fato de que a comparação entre o arranjo tripartite de algumas das pinturas da série e as anteriores Ateliê ou Pintor e Modelo possa render frutos. Talvez quem melhor tenha definido esse arranjo em sua dimensão estrutural seja Rosalind Krauss em seu mais recente estudo sobre o trabalho de Willem de Kooning, no qual frequentemente convoca a obra de Picasso

134 William Rubin já havia notado as ressonâncias entre Ateliê e Las Meninas. Cf. RUBIN, William. Picasso in the Museum of Modern Art. Nova lorque: The Museum of Modern Art, 1980, p. 123. Essa associação foi levada a cabo por GALASSI, 1996, op. cit., p. 147. Mais recentemente, Robert Lubar se propôs a desenvolver a relação entre essas pinturas de 1927-8 e a apropriação de Velázquez por Picasso. Cf. LUBAR, Robert. "Picasso, Las Meninas y el advenimiento del cubismo", in Olvidando Velázquez Las Meninas. Museu Picasso Barcelona, 2008, pp. 76-90.

135 Lubar definiu tanto Ateliê como Pintor e Modelo como alegorias da representação. Cf. LUBAR, op. cit., p. 77. 

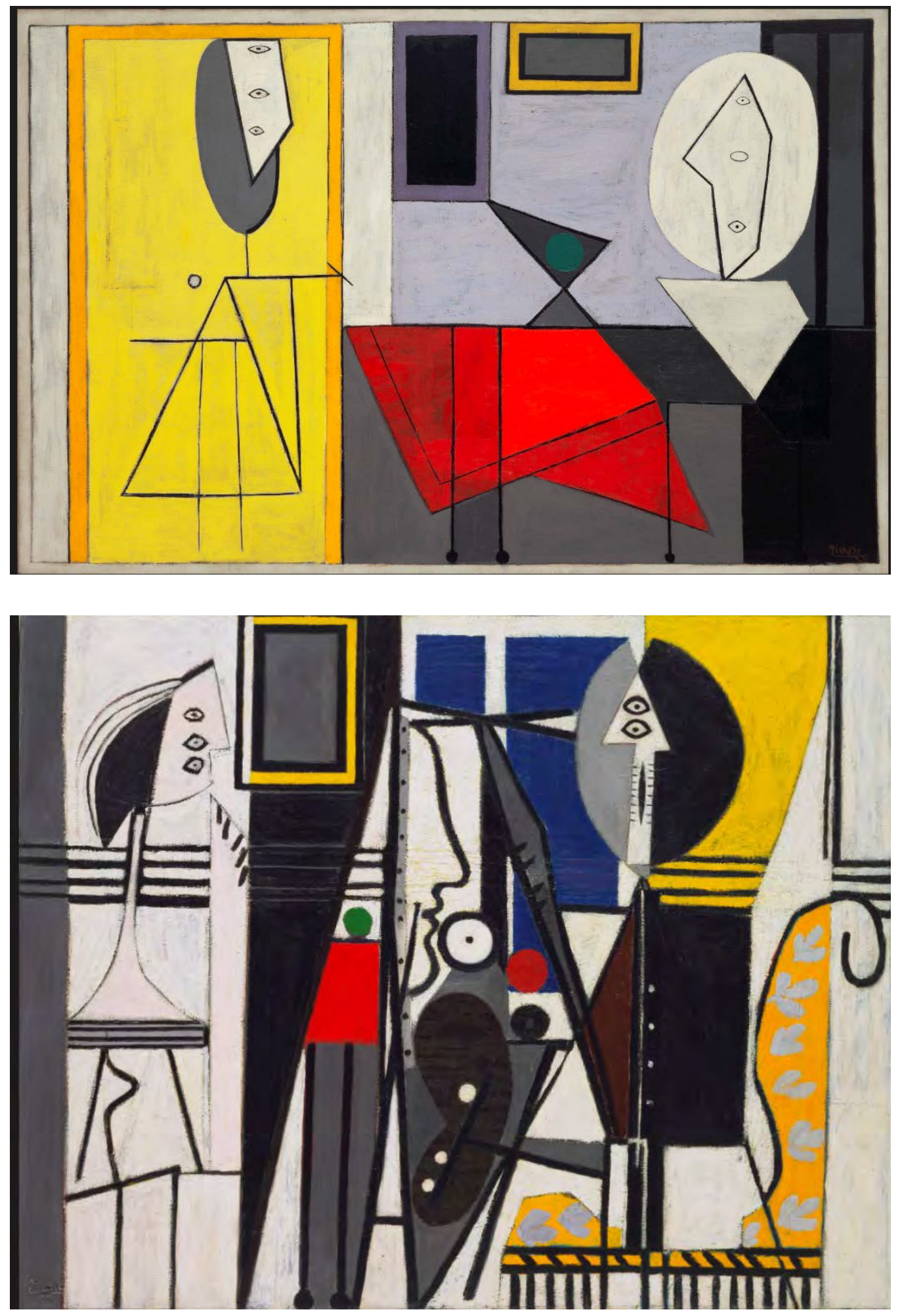

53 Pablo Picasso

Pintor e Modelo, 1928

Óleo sobre tela

$129.8 \times 163 \mathrm{~cm}$

Museu de Arte Moderna, Nova York.
54 Pablo Picasso.

Ateliê, 1927-8

Óleo sobre tela $149.9 \times 231.2 \mathrm{~cm}$.

Museu de Arte Moderna, Nova York. 
para diálogo. Para Krauss, a lógica tripartite das composições do final da década de 1920 se plasma numa estrutura cuja finalidade, em última instância, consiste em relacionar o ponto de vista e o ponto de fuga da pintura com a própria posição privilegiada do autor enquanto elemento organizador do campo visual ${ }^{136}$. Nessa lógica, a abertura que se vê ao fundo da estrutra horizontalizada funciona como uma fissura para projeção do espectador ( $a$ door "to let you in", nas palavras da autora ${ }^{137}$ ), como uma janela perspectiva que situa o observador tácito ante o espaço pictórico. Um observador, segundo Krauss, que ocupa a mesma posição que o artista, agora reduzido a nada mais que um ponto de vista implícito no campo visual.

Se assumirmos a comparação entre essas pinturas e as variações de Las Meninas de Picasso, veremos que a abertura que Krauss define como local de projeção do observador corresponde precisamente à porta pela qual irrompe a silhueta de José Nieto. Ao meu ver, entretanto, a equivalência entre um elemento e outro não opera de maneira plenamente satisfatória por algumas razões. Primeiro, porque tanto Ateliê como Pintore Modelo são pinturas organizadas a partir de um único eixo horizontal paralelo ao plano de representação, do qual resulta uma espacialidade compacta e aplanada. Essa organização horizontalizada rege a disposição das figuras, que, face a face, relacionam-se segundo uma lógica interna. Elas são delineadas num idioma radicalmente sintético. Volume, perspectiva e relações de profundidade parecem não ter lugar nesse circuito, salvo como sugestão esquemática de linhas de visão colaterais ao próprio eixo horizontal que organiza as pinturas. Nelas, a presença do observador, como vimos, opera somente como um elemento implícito no sistema, que encontra ressonância nas aberturas do plano de representação. No caso de Las Meninas, no entanto, a presença do observador não é de modo algum implícita, mas sim um mote estruturante que organiza cada um dos elementos da pintura. E para que isso ocorra, deve haver uma rotação em noventa graus do plano pictórico que faz com que, ao eixo horizontal da pintura, se some um eixo perpendicular, ele mesmo um vetor que põe em pauta a profundidade no campo visual.

É justamente por isso que o esquema proposto por Arasse para elucidar a construção espacial das anunciações italianas parece mais adequado para a compreensão da espacialidade de Las Meninas de Picasso que o próprio arranjo tripartite das pinturas do

136 KRAUSS, Rosalind. Willem de Kooning Nonstop. Chicago e Londres: The University of Chicago Press, 2015, pp. 6-10.

137 Ibid., p. 10. 
artista do final da década de I920. Não porque aquele modelo considerasse a presença do espectador como elemento em evidência, o que claramente não acontece. Mas porque ele nos mostra como a tensão entre o eixo horizontal que organiza a ação dramática das figuras em primeiro plano e o eixo ortogonal em profundidade é capaz de tornar o ponto de fuga do quadro simultaneamente um locus de projeção do observador da pintura e uma abertura atravessada por um movimento de penetração que, em sentido oposto, entrecruza o campo pictórico e incide no olhar do espectador. A presença de uma figura postada no batente da porta faz com que a ambivalência desse movimento seja ainda mais pronunciada: por um lado, ela remete às tantas testemunhas oculares que comungam com o olhar do espectador em seu alongamento projetivo; por outro, ela é em si um flagrante que atinge o observador em sua centralidade estrutural.

De certa forma, esse movimento intermitente de propulsão e retração que caracteriza o olhar em profundidade do espectador de Las Meninas de Picasso faz lembrar aquele descrito por Leo Steinberg em seu decisivo ensaio O Bordel Filosófico, em que se dedica a analisar a célebre Les Demoiselles d'Avignon ${ }^{138}$. Endereçando-se detida e simultaneamente a diversos aspectos da pintura - entre eles a construção espacial, o engajamento do espectador, a compleição das figuras, só para citar alguns - Steinberg demonstra como as Demoiselles a um só tempo tragam e expelem o olhar do espectador num fluxo de alternância que faz com que a pintura se torne, entre outras coisas, uma metáfora visual do coito. É curioso que o crítico de arte e historiador estadunidense, de maneira perspicaz, tenha atentado para o fato de que esse movimento palpitante só é possível devido a um giro em noventa graus da relação entre o espectador e o campo pictórico, que torna a própria experiência do observador um fator central da pintura. Enfim, trataremos das relações entre algumas das complexas proposições desse texto e a série Las Meninas de Picasso mais adiante. Por ora, basta sinalizar que, em uma singela nota, o próprio Steinberg reconhece que o movimento erótico de protensão e retensão característico de Les Demoiselles d'Avignon está presente de forma remota até mesmo em alguns dos trabalhos de Picasso que aparentam maior inocência. Não seriam Las Meninas como um desses trabalhos capazes de insinuar visualmente o movimento do coito sem necessariamente torná-lo manifesto em qualquer momento preciso?

138 STEINBERG, "Philosophical Brothel", op. cit., p. 24. 
Se assim for, somos levados a crer que Las Meninas de Picasso estão impregnadas por uma energia sexual que se mantém sob tensão ao longo da série sem, no entanto, expressá-la de forma direta. Galassi, ao comentar algumas das pinturas (precisamente as variações I 2 e I3), refere-se a uma energia crua e a um modo quase sub-representacional de possessão que faz recordar Les Demoiselles d'Avignon, propondo que nessas variações o que está em jogo seja uma equação bordel-ateliế ${ }^{139}$. Maria Teresa Ocaña o coloca de forma mais explícita e nomeia seu texto sobre a série de "La violación de Las Meninas". Ou nem tão explícita assim, já que embora o título soe provocativo, o texto não corresponde à promessa que dele subentende-se e o leitor, desorientado e sem compreender o porquê do uso de uma palavra com um sentido sexual tão forte, se sente como numa aposta a fundo perdido. Quando muito, contenta-se com as palavras finais da autora, que defende que "o grotesco roça o absurdo e a burla não parece isenta de crueldade ${ }^{140}$ ", formulação que sequer corresponde à toada morna e descritiva do restante do texto.

Ao fim e ao cabo, tanto a associação "bordel/ateliê" de Galassi quanto o título provocativo de Ocaña soam mais como intuições sobre Las Meninas que como afirmações plenamente justificadas. Intuições que, não obstante, nos dizem algo sobre a série. A "crueldade" de Picasso, de fato, chamou a atenção não apenas de Maria Teresa Ocaña, mas também de outros que se propuseram a refletir sobre a série. Nós mesmos já descrevemos o tom de ameaça que a figura de José Nieto pode imprimir na série. Roland Penrose, como havíamos dito, define Las Meninas como uma "paródia cruel ${ }^{141}$ ", evocando o ácido humor espanhol de Goya para descrevê-la. John Anderson, por sua vez, refere-se ao ambiente que toma conta das variações de Picasso como uma artificial "casa de bonecas", onde "[...] distorções, desfigurações, a violação de quaisquer leis morais ou estéticas, a negação de todas as prerrogativas, não têm censura e são legítimas ${ }^{\mathrm{I4} 2 "}$.

É difícil ignorar que afirmações como a de Anderson nutrem-se, mesmo que de forma indireta, da própria fama em torno da imagem de Picasso - que, diga-se de passagem, ele mesmo fazia questão de alimentar - como artista com "A" maiúsculo, como gênio

139 GALASSI, 1993, p. 163-164.

140 OCAÑA, Maria Teresa. op. cit., p. 154

141 PENROSE, Roland. Op. cit., p. 498.

142 ANDERSON, John. op cit., p. 161. Traduzido livremente do original: "In it, combinations of events, situations, distortions, disfigurements, violation of any laws moral or aesthetics, denial of all prerrogative, are uncensored and legitimate". 
criativo, capaz de, num toque de pincel e sem qualquer pudor, desmembrar o corpo de sua modelo declarando sua descontinuidade enquanto objeto para então reconstruí-lo a seu bel-prazer. Crueza iconoclasta que, nunca é demais recordar, encorajara não somente o aplauso daqueles dispostos a glorificar a força titânica do artista, como também o brado de seus detratores, capazes de projetar no desmembramento da imagem humana uma crueldade desejada a seu original. Mas é curioso notar que as distorções e desfigurações evocadas por Anderson não estão presentes em uma sequer das variações de Las Meninas. Ao menos não no que diz respeito à imagem do corpo, que permanece íntegra mesmo quando os gestos enfatizados atingem o ápice de sua força dramática. Basta olhar para algumas das variações que Picasso havia feito três anos antes a partir de Femmes d'Alger, de Delacroix, para que constatemos que nenhuma das infindáveis torções e distorções de emaranhados corpóreos realizadas pelo artista e brilhantemente descritas por Leo Steinberg ${ }^{143}$ fazem-se sentir na série Las Meninas. Talvez a descrição de Anderson se refira ao traço caricaturesco e ao tom burlesco empregado por Picasso em algumas das variações, mas se esse for o caso o forte apelo de palavras como "desfiguração" ou "violação de leis morais" soam como, no mínimo, um exagero.

Não se pode negar que, de certa forma, John Anderson escamoteia seus excessos ao encerrar as operações de Picasso no universo imaginário da "casa de bonecas", que, nunca é demais recordar, foi inventada (ao menos em sua dimensão alegórica) pelo próprio autor, e não pelo artista. É lá, segundo ele, que a mente escrupulosa de Picasso pode divertir-se segundo suas próprias diretrizes, afinal, "bonecos podem imitar os humanos e serem, ainda assim, bonecos ${ }^{\mathrm{I} 44^{\prime}}$. Mas por mais que o autor defenda que é na artificialidade desse ambiente que Picasso encontra um indulto para blindar-se contra quaisquer admoestações morais, a dúvida que resta é se o "faz de contas" criado por Anderson não é ele mesmo uma forma de proteção, não da parte de Picasso, como se faz crer, mas do próprio autor em sua condição de espectador - que deve enfrentar-se com as devaneios escrupulosos e concupiscentes de seu olhar especulativo frente a uma série altamente sugestiva, como é o caso de Las Meninas.

143 STEINBERG, Leo. "Mulheres Argelinas de Picasso em Aberto", em Outros Critérios: confrontos com a arte do século XX. São Paulo: Cosac Naify, pp. 163-189.

144 ANDERSON, op. cit. p. 161. Traduzido livremente do original: "[...] the scrupulous mind can play at constructions after its own heart - where toys may imitate the human but be toys still". 
Em uma breve afirmação, Roland Penrose parece sintetizar o cerne da questão:

Nada de distorções, deformações, violações morais. Nesse pequeno trecho, Penrose parece apenas intuir a existência de um elo entre o tratamento simultaneamente violento e terno das figuras e a resposta subjetiva do espectador à série. Volto a insistir: se muitos souberam assinalar a existência do "toque de crueldade" que permeia a série, poucos se propuseram a identificar com precisão de que se tratava essa violência, não levando às ultimas consequências suas próprias sentenças.

Diante disso, me arrisco a levar a proposição de Penrose adiante, formulando-a de uma maneira ligeiramente distinta. Vimos anteriormente que em toda a primeira parte da série estimula-se uma atitude curiosa por parte do espectador, que se depreende da faina analítica de Picasso em relação aos gestos, expressões e posturas das figuras femininas na pintura. Que seu corolário é a irrupção de uma silhueta em flagrante, que parece capturar o espectador em seu próprio exercício de olhar, em sua sanha curiosa e perscrutadora. Que a eclosão dessa silhueta em flagrante está articulada a uma estrutura espacial de constrição e propulsão que sugere a pregnância de uma energia sexual latente, mas somente na medida em que essa espacialidade impulsiona um movimento de projeção e retração do olhar do espectador capaz de encontrar ressonâncias no ritmo do coito.

O fato é que nessa empreitada a alusão sexual não tem lugar senão por correspondência estrutural. Tampouco uma atitude violenta é plenamente identificável no decorrer da série - a não ser como vaga sugestão que se dilui no tratamento burlesco das figuras. Nem mesmo o ímpeto iconoclasta de que Picasso amiúde lança mão na maneira de figurar o corpo parece, nesse caso, desempenhar um papel crucial- o que não exclui o fato de que um afã caliginoso esteja sempre às rondas do espectador. Ainda assim,

145 PENROSE, Roland. op. cit., p. 497-8. Com ênfase em itálico de minha autoria e traduzido livremente do original: "Le traitement, où tendresse et violence se côtoient, joue avec les émotions du spectateur". 
é somente através da mediação de sua experiência subjetiva que violência e sexualidade se sobrepõem. Dito de outro modo: violência, ternura e, em última instância, desejo de violação não são expressos nas pinturas, mas estão contidos no olhar do espectador que, ativamente solicitado, fornece sua resposta subjetiva à série. Essa maneira de jogar com as emoções do espectador opera do início ao fim da série e é articulada de inúmeras formas, como tentei demonstrar até aqui através da análise de cada uma das sequências de pinturas, mas é sobretudo através do apelo a uma relação implícita entre olhar, curiosidade e delito que ela é capaz de render os frutos mais vistosos.

Somente um parênteses, no entanto. É claro que com essa formulação não pretendo ingenuamente censurar a historiografia jogando-lhe nas costas o peso de uma repreensão moral originalmente dirigida ao artista. Até mesmo porque se a resposta subjetiva do espectador à pintura se dá através de seu próprio olhar, como suponho, isso ocorre somente porquanto esse olhar é ele mesmo tematizado, estimulado e construído por Picasso ao longo da série - que o faz eliminando qualquer reembolso de ordem terapêutica ou compensatória. Tampouco pretendo sugerir que o espectador seja o "derradeiro produtor de sentido" ${ }^{146}$ da série, como se estivesse autorizado a superinterpretar as obras para revesti-las de uma camada de significação que elas mesmas não parecem interessadas em perseguir ${ }^{147}$. Proponho apenas que Las Meninas seja uma série que trabalha diretamente em relação ao olhar e às emoções do espectador, colocando-os em evidência como instâncias atreladas.

Espero ter demonstrado como isso ocorre ao longo das análises de pinturas e sequências. Como espero também ter sinalizado algo mais: se Picasso organiza a estrutura

146 Trecho retirado da introdução de Christopher Green a uma publicação organizada por ele mesmo a respeito de Les Demoiselles d'Avignon: "those meanings are to be found in the spectator as much as in Picasso, for the spectator is not merely an implied reader looking in reflectivity from outside, but [...] the ultimate maker of meaning". Em: GREEN, Christopher. "An introduction to 'Les Demoiselles d'Avignon'", in Picasso's Les Demoiselles d'Avignon. Cambridge: Cambridge University Press, 2001, p. 9.

147 Faço essa ressalva com vista à discussão sobre a experiência do espectador em Les Demoiselles d'Avignon, promovida por Lisa Florman e motivada pela importância que adquiriu o supracitado ensaio de Leo Steinberg sobre a pintura. Florman critica - ao meu ver, acertadamente as leituras que investem o espectador de uma autoridade enviesada comprometendo a interpretação da pintura. Veja-se: FLORMAN, Lisa. "The Difference Experience makes in 'The Philosophical Brothel'". Art Bulletin v. 85, n. 4 (Dezembro, 2003), 769-784. Para esse ponto em específico, cf. pp. 770-771 e as notas 3 e 4 . 
de sua série em torno do olhar do espectador (implicando-o diretamente como centro de atenção do quadro), ele o faz de modo a colocar sua própria condição de centralidade sob tensão. Nada mais adequado, portanto, que o constante retorno ao momento do flagrante, o qual, como vimos, desempenha um papel crucial ao longo da série. Isso significa que a resposta subjetiva do espectador a Las Meninas estará, de uma maneira ou de outra, subordinada à experiência de centralização e descentralização do olhar - ou, se não subordinada, ao menos condicionada a pressenti-la como ameaça.

Formulada essa hipótese, faz-se necessário colocá-la à prova. Em primeiro lugar, não se pode tomar por certo o elo entre olhar e a resposta subjetiva do espectador sem antes averiguar de que maneiras efetivamente esse olhar é solicitado. Devo admitir que esse trabalho foi feito - ao menos em parte - ao longo das análises de imagem, mas ainda restam pontos cruciais a serem discutidos. Como se sabe, Leo Steinberg, no já citado $O$ Bordel Filosófico(1972), produziu uma extensa análise de Les Demoiselles d'Avignon que, entre outras coisas, explora o "apelo imediato" que essa pintura exerce no espectador. Tratase de um texto decisivo, que, escrito há mais de quarenta anos, segue sendo fundamental para a compreensão do olhar na obra de Picasso. Para melhor apreender as relações entre as pinturas, o olhar e a experiência subjetiva do observador, portanto, proponho dedicar-me, na seção a seguir, a examinar as últimas sequências de Las Meninas com vista, simultaneamente, ao raciocínio de Steinberg sobre Les Demoiselles d'Avignon e às conclusões parciais das análises desenvolvidas até aqui.

Outro ponto a ser interrogado é em que, exatamente, consiste esse olhar em flagrante e de que maneiras ele pode efetivamente desestabilizar a prerrogativa de centralidade do observador. E mais: se o observador de Las Meninas não pode senão afrontar a série a partir de uma posição de centralidade em ameaça, como essa nova condição é capaz de modificar a experiência do olhar em questão? Ou, dito de outro modo, quais as consequências do flagrante para o próprio ato de olhar? Para responder a essas perguntas, sugiro que nos voltemos a outras imagens de Picasso nas quais um observador remoto é colocado em relação ao observador da pintura, ou, mais precisamente, nas quais a experiência do olhar é tematizada. Afinal, como já disse Steinberg, "o melhor comentário sobre Picasso é outro Picasso ${ }^{\mathrm{I} 48^{\prime \prime}}$.

148 STEINBERG, The Philosophical Brothel, op. cit., p. 22. Traduzido livremente, do original: "The best commentary on a Picasso is another Picasso". 
Mas não deixemos que Picasso sozinho responda a essas questões. Se o artista fez do olhar um topus a ser perpetuamente explorado ao longo de sua extensa trajetória, ele tampouco lançou-se isolado nessa empreitada. Desde uma perspectiva distinta e quatorze anos antes que o artista realizasse suas variações de Las Meninas, Jean-Paul Sartre havia publicado seu tratado filosófico O Ser e o $\mathrm{Nada}^{\mathrm{I} 49}$, no qual dedicara um dos capítulos a esboçar uma concepção de olhar que, em muitos pontos, pode nos auxiliar na compreensão de como o encontro com um olhar em flagrante é capaz de desestabilizar a centralidade do observador, fazendo-o entrar na dimensão da existência do outro. Guardadas as diferenças e especificidades de cada área de conhecimento, proponho, no segundo capítulo, cotejar a concepção de olhar esboçada por Sartre e o trabalho de Picasso - sem qualquer intenção de suprir as minúcias de uma abordagem filosófica, o que fugiria ao escopo dessa dissertação, mas somente de modo a localizar e discernir a presença e as consequências de determinado estatuto ontológico do olhar que, por vezes, parece engastado nas obras de Picasso.

Em seguida restará, ainda, um último ponto a ser examinado. Se, conforme sinalizamos, a experiência de descentralização do espectador é permeada por uma trama entre olhar, curiosidade e delito, cumpre interrogar de que modos, precisamente, essa articulação ocorre. Mais uma vez, insistirei no fato de que essa não parece uma elaboração concernente exclusivamente a Picasso - a tríade olhar, curiosidade e delito, como teremos visto, pode ser localizada até mesmo no pensamento de Sartre, e é também fundamental na obra de artistas de peso naquele período, como por exemplo Marcel Duchamp. Na última sessão da dissertação, trataremos de compreender como no final dos anos de I950 e dali em diante, uma determinada concepção de olhar que leva imbricadas as noções de perscrutação e ameaça ganha repercussão tanto na produção artística como em certas correntes de pensamento que, na esteira de Sartre, se propõem a pautar a questão do olhar em seus desdobramentos artísticos e filosóficos.

Ao final desse percurso, talvez seja possível enxergar como Las Meninas de Picasso dialogam com um espectro de questões e desafios partilhados pela produção artística de seu próprio tempo - inclusive por aqueles cujo trabalho o próprio Picasso se negava a reconhecer. A fama e o prestígio do artista poderiam nos fazer tomá-lo por certo, não fosse o gradual isolamento - sobretudo em relação à cena artística contemporânea

149 SARTRE, Jean-Paul. O ser e o Nada: Ensaio de Ontologia Fenomenológica, trad. Paulo Perdigão, 24 ed. Petrópolis, RJ: Vozes, 2015. 
- a que Picasso progressivamente se submetera no decorrer de sua vida. Isso é ao menos o que amiúde se diz: após a Segunda Guerra Mundial, a história progressivamente para de ajudar Picasso, que, desamparado, busca no passado sua grande fonte de inspiração ${ }^{150}$. Mas não nos precipitemos: ainda que naquele momento, nos idos da década de I950, o septuagenário Picasso assinalasse prescindir do amparo e da companhia de seus pares para lançar-se a um penoso remar contra a maré, talvez a aposta não tenha sido apenas o mero capricho de um náufrago. 


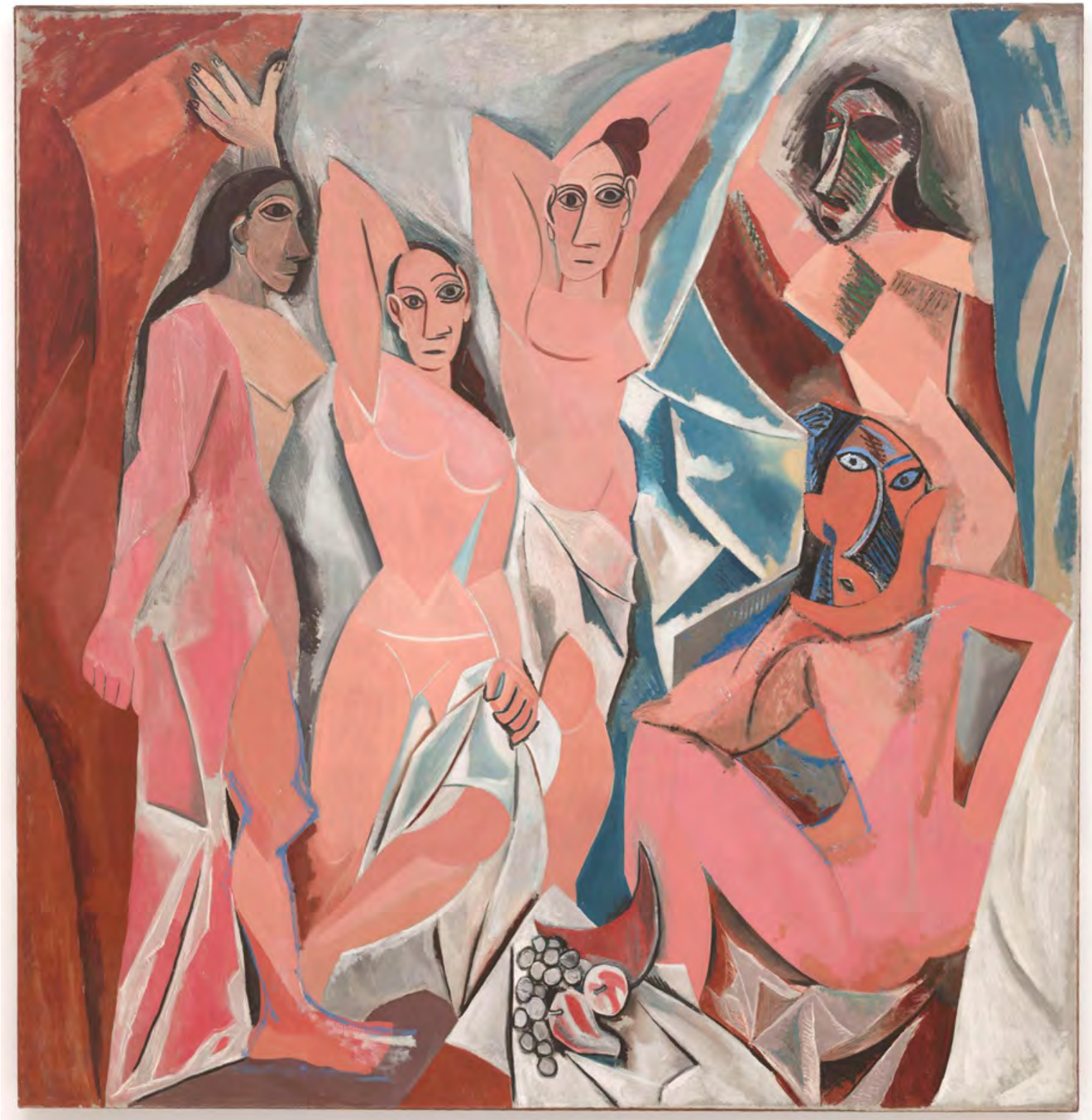

55 Pablo Picasso.

Les Demoiselles d'Avignon, 1907

Óleo sobre tela

$243.9 \times 233.7 \mathrm{~cm}$.

Museu de Arte Moderna, Nova York. 


\section{A SÉRIE, ENTRE OUTROS: PARTE III}

Há uma passagem marcante do seminal ensaio "O bordel filosófico" (1972) em que Leo Steinberg arrisca-se a dizer que nenhuma pintura jamais endereçou-se ao espectador com intensidade comparável a Les Demoiselles d'Avignon (1907), de Picasso (fig. 55) ${ }^{\text {I5I. }}$. À exceção, contudo, de Las Meninas de Velázquez.

Mais adiante, ao anunciar as maneiras pelas quais Picasso logra "arrebatar" o espectador com tamanho apelo, Steinberg recorre novamente ao paralelo entre Les Demoiselles e Las Meninas, mas dessa vez lança mão de uma insólita referência para mediá-lo: o pioneiro estudo do historiador da arte austro-húngaro Alois Riegl a respeito dos retratos de grupo holandeses dos séculos XVI e XVII ${ }^{152}$. Para Steinberg, tanto Les Demoiselles (em sua versão final) quanto Las Meninas de Velázquez compartilham com esse gênero particular de pinturas (bastante comum na Holanda meridional e setentrional, mas quase completamente desconhecido pela tradição mediterrânea) certas características formais de crucial relevância.

A mais evidente dessas características compartilhadas, no caso de Les Demoiselles, é a recusa aos princípios de teatralidade que garantiam à pintura barroca italiana sua unidade interna. À diferença da tradição mediterrânea - consagrada por recorrer ao poder centralizador de uma ação para asseverar a integridade espaço-temporal da pintura - a tradição nórdica elimina a própria existência de um acontecimento unificador como princípio fundamental de suas obras. Suprimida a ação, o parâmetro que permite graduar a reação das figuras representadas em níveis escalonados de passividade e atividade é substituído por um estado de máxima atenção de cada uma das figuras, que jamais interagem entre si, mas direcionam-se direta e exclusivamente ao espectador. De modo semelhante, ao longo do extenso processo de gestação e elaboração de Les Demoiselles d'Avignon (que resultou em aproximadamente mil esboços e desenhos preparatórios), Picasso elimina progressivamente os elementos teatrais que em um primeiro momento

151 "Since no other painting (Las Meninas excepted) addresses the spectator with comparable intensity, how does this intensity of address accord with the abstract purposes normally ascribed to the Demoiselles", em: STEINBERG, 1972, op. cit., p. 11.

152 ibid., p. 13-14. 
regiam a estrutura interna da composição. A interação entre as figuras na pintura cessa, e cada uma delas passa a dirigir-se exclusivamente ao espectador. Em Les Demoiselles, portanto, como no modelo descrito por Riegl, a unidade espacial da composição não está vinculada a um fator interno, mas externo - pois será sempre mediada pela experiência subjetiva do espectador.

Claro que o mais provavel é que Picasso - Steinberg admite - não tenha tido contato com a teoria de Riegl ou mesmo com as pinturas a que ele se refere ${ }^{153}$. Mas ele conhecia, como é bem sabido, Las Meninas, obra-prima de sua terra natal, que o Museu do Prado qualificava em letras garrafais como Obra Culminante da Pintura Universal - pintura que, de acordo com Steinberg, expressa de forma excepcional a intuição nórdica presente nos retratos de grupo estudados por Riegl.

Picasso, assim como Velázquez quase trezentos anos antes, teria orientado sua arte a ambas as tradições, nórdica e mediterrânea.

A comparação é acurada, embora seja difícil negar que a alusão a Las Meninas não deixa de ser uma alternativa (ou uma poderosa solução) encontrada por Steinberg para mediar a afinidade entre Les Demoiselles e o modelo holandês. O que não exclui seu interesse para nós, evidentemente. Primeiro porque ainda que Las Meninas tenha aparecido como referência explícita por primeira vez na obra de Picasso em I957, sua tácita presença já se fazia sentir ao menos cinquenta anos antes. ${ }^{154} \mathrm{E}$ justamente em uma obra de seminal importância para a pintura no século XX, em uma tela que reformula de modo decisivo a relação entre o olhar do espectador e a unidade espaço-temporal da composição (à qual nos dedicamos extensivamente no primeiro capítulo).

Nada mais adequado, portanto, que nos voltarmos a Les Demoiselles s'Avignon e Las Meninas de Picasso simultaneamente - à luz de suas semelhanças e diferenças

153 Riegl introduz seu estudo justamente apontando o fato de que esses retratos de dimensões imponentes estão presentes em grande parte dos museus, hotéis, hospitais, hospícios, mansões e guildas de cidades do interior da Holanda setentrional e meridional, mas que são quase completamente ignorados no exterior do país e mesmo nas províncias vizinhas. Cf. RIEGL, Alois. Le Portrait de Groupe Hollandais, tra. Aurélie Duthoo e Etienne Jollet. Paris: Hazan, 2008, pp. 35-36.

154 Justiça seja feita, há uma cópia de Picasso de 1896-7 (hoje no Museu Picasso Barcelona), realizada na primeira visita do artista ao Museu do Prado em Madri, que mostra as duas figuras centrais de Las Meninas: a infanta e sua dama de companhia, que tanto instigaram Picasso em 1957. Como se trata de um pequeno esboço realizado aos quinze anos de idade, desconsidero sua relevância para a afirmação. 
incontestáveis, é claro, e sem perder de horizonte, em um primeiro momento, as reflexões de Steinberg sobre a pintura de 1907.

\section{Les Demoiselles/ Las Meninas}

Ao voltar-se detidamente ao laborioso processo de gestação de Les Demoiselles d'Avignon, Steinberg observa que os primeiros desses desenhos e esboços preparatórios apresentavam não somente os cinco nus femininos que vemos na versão final da pintura, mas também, entre elas, duas figuras masculinas vestidas que interagiam com as mulheres no bordel.

Steinberg não foi o primeiro a notá-lo, cumpre ressaltar. O então diretor do Museu de Arte Moderna de Nova York, Alfred. Barr Jr ${ }^{155}$, por exemplo, já havia identificado a presença dessas figuras, que logo foram identificadas como um marinheiro entre as prostitutas e um estudante de medicina que, à esquerda, anuncia sua súbita aparição no ambiente. Elas foram importantes para que Barr formulasse sua hipótese de que Demoiselles teria sido concebida inicialmente como uma espécie de memento mori, como uma alegoria dos perigos e pecados do sexo. Com o passar do tempo, Picasso (antimoralista por princípio) não tardaria em suprimir a dimensão alegórica da pintura: tratava-se, naquele momento, de dar os primeiros passos rumo à intrépida caminhada que conduzirá à criação do cubismo.

Para Steinberg, no entanto, não era o cubismo o que estava em questão.

Havia, decerto, um abandono das soluções alegóricas na versão final de Demoiselles. Nos primeiros meses dedicados à elaboração da pintura, Picasso, de fato, havia se concentrado intensamente em desenhos concebidos a partir de uma espacialidade e dramaticidade altamente teatrais (Steinberg as define barrocas, William Rubin as definiu narrativas $\left.{ }^{156}\right)$, buscando obsessivamente acentuar a relação que as figuras estabeleciam entre si. Então, num movimento abrupto, transforma o estudante de medicina em uma

155 BARR Jr., Alfred H., Picasso: Fifty Years of his Art. Nova York: The Museum of Modern Art, 1946, p. 57

156 RUBIN, William. "From Narrative to 'Iconic' Picasso': The Burried Allegory in Bread and Fruitdish and the role of Les Demoiselles d'Avignon", in Art Bulletin 65, no. 4 (Dezembro 1983) 615-49. Veja-se também o estudo detalhado de Rubin realizado após a publicação de "O Bordel Filosófico": RUBIN, William. "The Genesis of Les Demoiselles d'Avignon", in: Studies on Modern Art 3, op. cit., pp. 13-118. 
figura feminina e, algum tempo depois, elimina também o marinheiro. Suprimidas as figuras masculinas, a obra passou a ser concebida como um grupo de cinco nus femininos - solução que ganha corpo na tela final. Todas essas mudanças fazem com que seja cada vez mais difícil situar a cena de modo narrativo ou mesmo de maneira alegórica.

Mas ainda que despido de dimensões alegóricas ou narrativas, o evento apresentado segue sendo o mesmo: uma epifania, a súbita entrada de alguém em um bordel ${ }^{157}$. Agora, porém, rotacionado noventa graus em direção ao espectador, que situa-se no polo oposto ao espaço pictórico. Com esse movimento, a unidade da pintura (célebre por suas rupturas estilísticas internas) passa a residir "sobretudo na consciência atônita de um espectador que se vê visto ${ }^{158 "}$.

Um dos grandes feitos de Steinberg talvez tenha sido enfatizar a existência de um elo entre o total isolamento das cinco prostitutas - logrado precisamente pelo uso de um princípio anti-narrativo bastante semelhante àquele descrito por Riegl - e o papel que o espectador desempenha na obra. Repito: não se tratava de um prenúncio do cubismo, mas de um novo regime de visualidade em que o olhar do espectador é arrebatado para o centro da pintura, ainda que se situe no exterior dela.

Não é de se estranhar que Steinberg tenha, portanto, recorrido a Velázquez para especificá-lo. Las Meninas, afinal, como poucas pinturas antes dela, trouxera à baila as complexidades inerentes ao lugar do espectador diante do quadro. Além disso, se o que está em jogo é a epifania de uma interrupção, essa é indubitavelmente uma obra perfeita a ser evocada. Lembremos do estranho efeito de instantaneidade da pintura, de sua espontaneidade não ortodoxa, de seus gestos disparatados, de seu olhar em direção ao espectador, enfim, tudo aquilo que Picasso explora insistentemente em sua própria versão de Las Meninas em 1957; versão esta que, como buscamos argumentar anteriormente, gira sobretudo em torno do flagrante - momento em que o espectador descobre-se visto.

Há, no entanto, algumas diferenças marcantes - tanto entre Las Meninas de Picasso e Las Meninas de Velázquez quanto entre ambas e Les Demoiselles d’Avignon. A mais evidente é que, no caso de Demoiselles, ainda que a interrupção epifânica siga sendo o tema, a figura

\section{STEINBERG, 1988, op. cit, p. 13.}

158 Ibid, p. 12. Traduzido livremente, do original: "The unity of the picture, famous for its internal stylistic disruptions, resides above all in the startled consciousness of a viewer who sees himself seen". 
masculina que antes interrompia a cena desde o interior da pintura - o "intruso", nas palavras de Steinberg ${ }^{159}$ - foi eliminada. Com a rotação do espaço pictório em noventa graus, a função dessa figura masculina passou, de certo modo, a condensar-se no próprio olhar do espectador: é ele, doravante, quem interrompe a cena.

Não é fruto do acaso que a partir da década de 1980 (pouco depois da publicação de "O bordel filosófico") a crítica feminista tenha denunciado, sucessivas vezes, a prerrogativa masculina do olhar em Demoiselles ${ }^{160}$. Seguindo a lógica da pintura (como revelada pelo ensaio de Steinberg), o espectador seria implicitamente um homem branco, heterossexual e europeu ${ }^{161}$ - e o "Bordel filosófico", consequentemente, androcêntrico.

O ponto gerou uma contenda nas páginas do quadragésimo nono volume de Art Journal $^{162}$, à qual retornaremos indiretamente ao longo de todo esse capítulo. Por ora, basta sinalizar que mesmo Steinberg reconhecia a pintura como um "embate entre os sexos", uma "onda de agressão feminina" ${ }^{163}$. O que, evidentemente, jamais poderia se dar em uma pintura como Las Meninas de Velázquez, em que a identidade do espectador não é exatamente o que está em causa.

Mas e quanto ao espectador de Las Meninas de Picasso? Seria ele herdeiro de uma universalidade tácita ou caberia imputar-lhe a identidade sexual que caracteriza o espectador em Demoiselles? Talvez seja precipitado respondê-lo desde já. Em todo caso, é esse espectador que Picasso parece interpelar quando, nas últimas sequências de sua série, recorre a recursos bastante semelhantes àqueles que havia mobilizado cinquenta anos antes em Les Demoiselles d'Avignon.

Se, nas últimas sequências comentadas até aqui (variações 35 a 4I), Picasso dedicarase mais uma vez a perscrutar os gestos da infanta, de sua dama de companhia e do anão

159 Idem.,

160 DUNCAN, Carol. "The MoMA's Hot Mamas", Art Journal, Vol. 48, No. 2, Images of Rule: Issues of Interpretation (Summer, 1989), pp. 171-178; BROUDE, Norma. "Picasso, Artist of the Century (Late Nineteenth)", Arts (outubro, 1980), pp. 84 a 86

161 CHAVE, Anna C. "New Encounters with Les Demoiselles d'Avignon: Gender, Race and the Origins of Cubism". The Art Bulletin. Vol. 76, No. 4 (Dezembro, 1994), pp. 596-611.

162 STEINBERG, Leo; DUNCAN, Carol. "From Leo Steinberg", in Art Journal, vol. 49, No. 2, Depictions of the Dispossessed (Summer, 1990), p. 207.

163 "a clash of sexes" e "wave of female aggression", no original. Cf. STEINBERG, 1979, op. cit., pp. 10 e 12. 


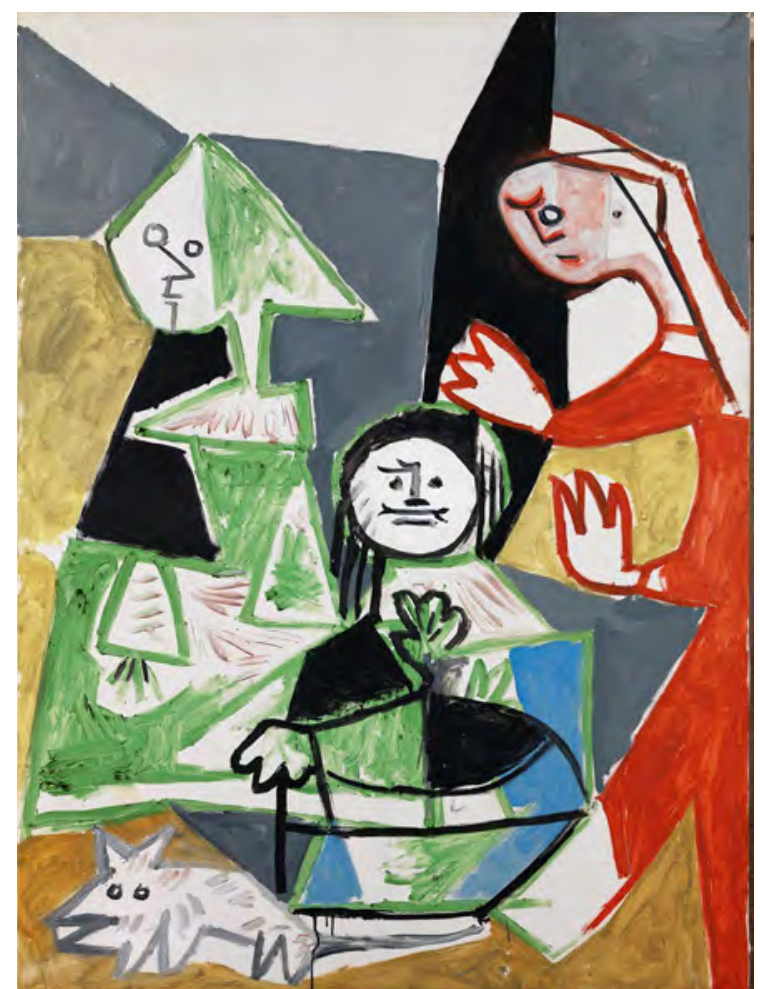

56 Las Meninas [Isabel de Velasco, María Bárbola y Nicolasito Pertusato] Cannes, 24 de outubro de 1957

Óleo sobre tela

$129,5 \times 96,5 \mathrm{~cm}$

Museu Picasso, Barcelona

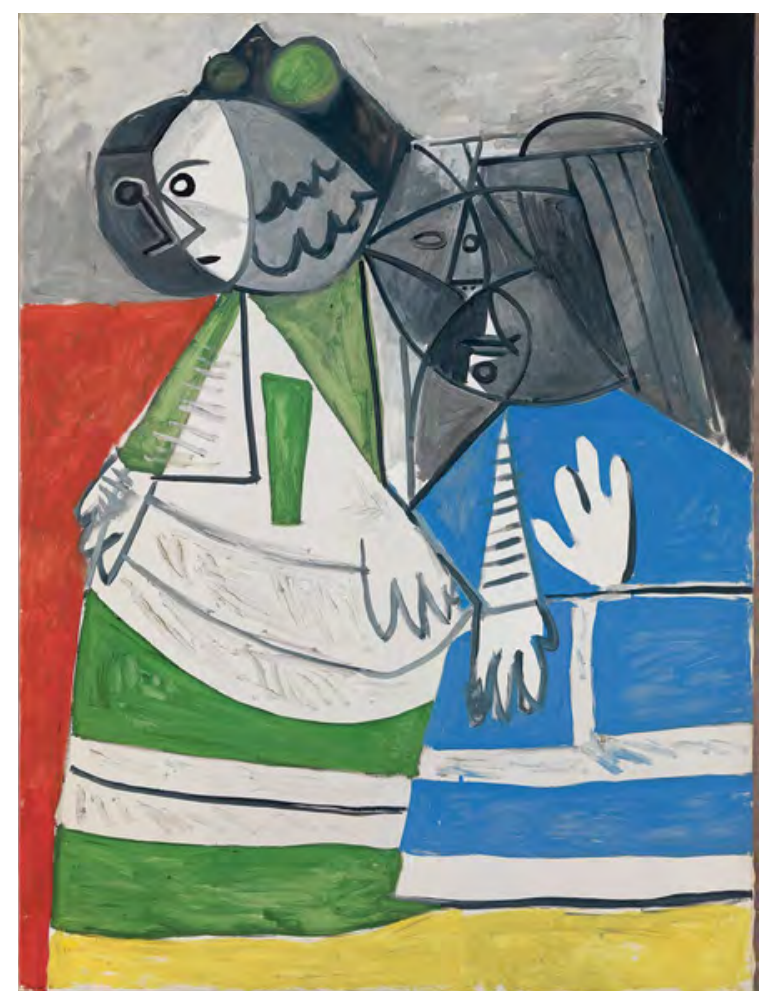

57 Las Meninas [Isabel de Velasco, María Bárbola y Nicolasito Pertusato] Cannes, 24 de octubre de 1957

Óleo sobre tela $130 \times 96 \mathrm{~cm}$

Museu Picasso, Barcelona 


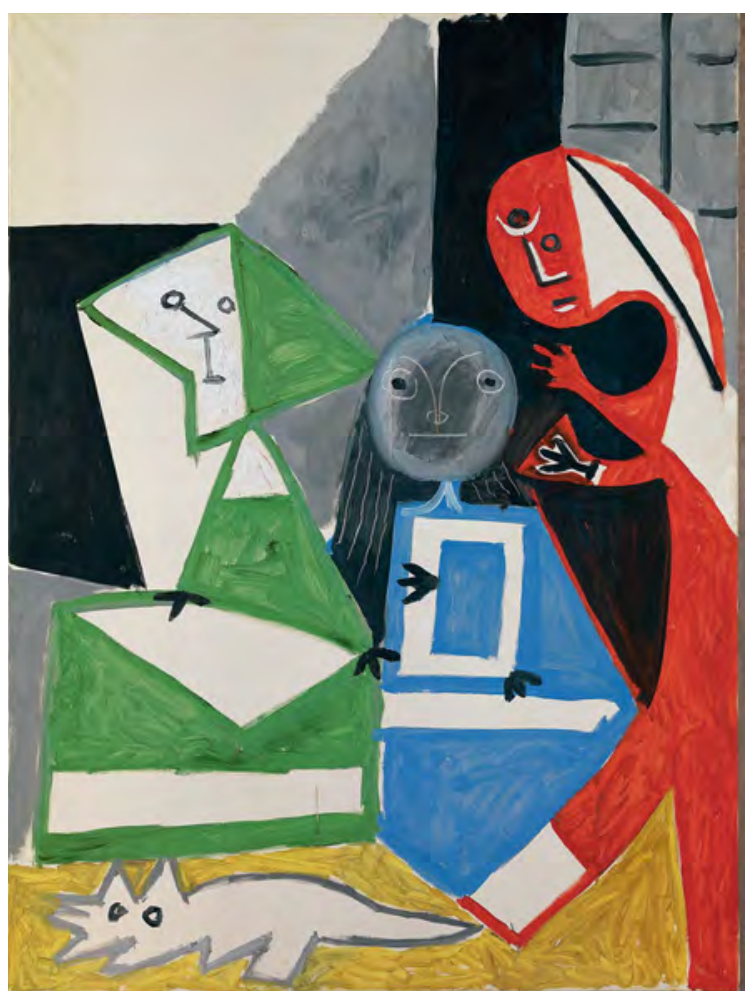

58 Las Meninas [Isabel de Velasco, María Bárbola y Nicolasito Pertusato] Cannes, 24 de outubro de 1957

Óleo sobre tela $130 \times 96 \mathrm{~cm}$

Museu Picasso, Barcelona

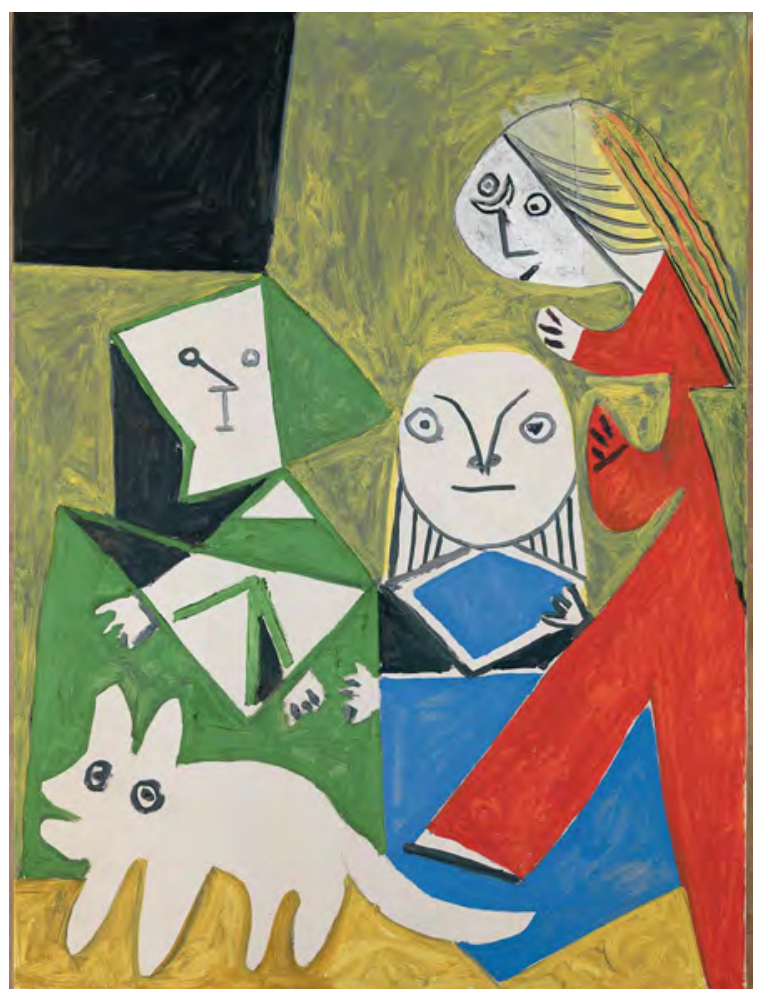

59 Las Meninas [Isabel de Velasco, María Bárbola y Nicolasito Pertusato] Cannes, 24 de outubro de 1957

Óleo sobre tela $130 \times 96 \mathrm{~cm}$

Museu Picasso, Barcelona 
Nicolás Perusato, bem como a possível interação entre eles, nas próximas pinturas traçará um movimento oposto. Volta o olhar de cada uma das personagens ao espectador, eliminando quaisquer resquícios da interrelação que estabeleciam. Mesmo as figuras que antes olhavam para a infanta ou para o centro da tela agora direcionam-se inequivocamente ao observador, fazendo dele o centro das atenções do quadro.

E nem todas as personagens do quadro de Velázquez são retratadas: como era de se esperar, do pintor, nem sinal. Do casal monárquico, menos ainda. E tampouco das duas figuras logo atrás do grupo em primeiro plano. Nas últimas sequências da série, Picasso se concentra somente nas figuras mais próximas ao observador: a infanta; María Agustina Sarmiento (a dama de companhia que outrora lhe oferecia o búcaro); Isabel de Velázco (a aia logo à sua direita); Maribárdola e Nicolás Perusato (os dois anões na margem direita da composição) e o caõzinho deitado à frente deles-todos em primeiro plano na pintura de Velázquez. E é claro, José Nieto ao fundo, à contraluz.

Da quadragésima segunda à quadragésima quarta variação (figs. 56, 58 e 59), Picasso concentra-se especificamente no grupo à direita da tela do Prado: os dois anões, Isabel Velázco e o cão. Na primeira dessas pinturas, o apelo ao espectador talvez seja o mais evidente. Maribárdola, ao centro, direciona ao espectador não só o olhar, mas também um gesto de mãos que se assemelha a um sinal de "pare". Esse gesto ressoa naquele da figura à sua direita, e ambas parecem interpelar o observador ou até mesmo querer comunicar-se com ele. O pequeno cão abaixo delas parece alarmado, diferentemente da pintura original, na qual descansava tranquilamente. Nas duas variações seguintes, esse mesmo grupo será alvo da atenção de Picasso, mas seu rosto e gestos passam a ser cada vez mais caricaturais.

Nas próximas pinturas (fig. 57), Picasso move-se gradualmente para o centro da composição de Velázquez. O anão à direita é o primeiro a desaparecer, e onde víamos três figuras passamos a ver duas. Na variação seguinte, desaparece Maribárdola, dando lugar à infanta. Quando a infanta volta a estar presente, vemos de soslaio também a silhueta de José Nieto, sempre à espreita. Ato contínuo, Picasso abrirá novamente o campo visual, permitindo que vejamos a totalidade das figuras, todos sempre mirando inequivocamente em nossa direção, voltados inapelavelmente ao lugar que ocupamos.

Entretanto, é evidente que a relação de imediaticidade que tanto surpreende o espectador em Les Demoiselles não tem a mesma intensidade nessas pinturas. Afinal, em Las Meninas, não somos tomados de assalto por uma "onda de agressão feminina". Não 
estamos em um bordel, o corpo das figuras não se exibe despudoradamente. Também a escala das figuras é distinta: em Demoiselles vemos de imediato cinco corpos femininos que ocupam toda a extensão espacial da tela (de cima a baixo, de um lado a outro); em Las Meninas, estamos diante de quatro figurinhas que parecem miniaturas a fitar-nos. E atrás delas, evidentemente, há a silhueta de José Nieto, ausente em Les Demoiselles.

É justamente a presença de José Nieto nos confins do campo visual aquilo que une e separa as últimas variações de Las Meninas de Les Demoiselles d'Avignon. Se, na pintura de 1907, a interação entre os nus femininos havia sido eliminada na mesma medida em que as figuras (masculinas) que interrompiam a cena foram obliteradas, no caso de Las Meninas essa dupla operação não ocorre de forma associada: por um lado, Picasso reúne as figuras em primeiro plano suprimindo a relação que estabeleciam entre si para voltá -las exclusivamente ao espectador; por outro, mantém um flagrante na soleira de uma porta pela qual o aposento representado se abre a um espaço exterior.

O flagrante (que em Demoiselles se condensava no próprio olhar do espectador) agora é facejado a outro flagrante no interior do espaço pictórico. Isso implica uma mediação a mais, evidentemente, que faz com que a pintura não seja mais um confronto entre o espectador e o corpo e o olhar daquelas que o fitam, mas entre espectador e o olhar daquele que o vê vendo. É claro que em ambos os casos são as ações de "ver" e "ser visto", ao fim e ao cabo, aquelas postas em xeque, mas de maneiras distintas.

Pois em Las Meninas, diferentemente do que ocorre em Demoiselles, Picasso se esforça por produzir uma sanha voyeurista no espectador - uma sanha que a própria dinâmica da série, por fim, acabará por confrontar. Lembremo-nos das implacáveis operações de escrutínio de que o artista lança mão desde o início da série (e de sua predileção por figuras femininas), de seus movimentos bruscos do conjunto em direção ao detalhe, de seu foco em nódulos de tensão, enfim. Todas essas são formas de estimular a curiosidade e a pulsão escopofílica do observador da série - condição ausente na obra de Velázquez, mas também em Demoiselles, pintura que tematiza o olhar mas jamais a curiosidade ou o prazer visual.

Digo isso porque o espectador, em Demoiselles, não tem escapatória: ver é condição inelutável para ele, o que não necessariamente implica uma relação de desejo ou regozijo em relação ao objeto visto. Além disso, se esse espectador é implicitamente masculino, como a literatura feminista procurou demonstrar, não podemos descartar o fato de que a maior parte dos homens que viu a pintura pela primeira vez nas condições privilegiadas do estúdio de Picasso - Matisse, Braques, Derain - não conseguiram reconhecer-se em 
sua condição de principais endereçados ${ }^{164}$. As reações foram as mais diversas: Demoiselles lhes parecia um "fracasso ${ }^{\mathrm{I} 65}$ ", "uma bagunça horrível ${ }^{166 ", ~ " a l g o ~ t e r r i ́ v e l ~ e ~ m o n s t r u o s o ~}{ }^{\mathrm{I} 67}$ ", "uma tragédia". Um célebre crítico e jornalista francês chegou a sugerir a Picasso que tentasse a caricatura ${ }^{168}$. Não é por acaso que, frente ao arsenal de reações estupefatas, Yve-Alain Bois tenha sugerido que Demoiselles seja uma pintura que angaria um fundamento libidinal semelhante ao do complexo de castração freudiana ${ }^{169}$. (E me arrisco a dizer que certo desconforto em relação à situação à qual o espectador é submetido em Les Demoiselles perdura tacitamente mesmo em abordagens mais recentes e nos mais consagrados e refinados estudos sobre a obra realizados até aqui..$^{170}$ )

Talvez esse seja um dos motivos pelos quais grande parte das interpretações feministas sobre essa pintura me parecem simplesmente insuficientes, não obstante suas decisivas e irrevogáveis denúncias. As mais consagradas dentre essas interpretações, cumpre assinalar, foram escritas - conforme notou Lisa Florman ${ }^{171}$ - sob o estímulo (direto ou indireto) do conceito de male gaze, que deriva do difundido e crucial ensaio "O prazer visual e o cinema narrativo", de Laura Mulvey ${ }^{172}$, ao qual dedicaremos mais

164 Quanto a esse aspecto, Tamar Garb nota que uma das primeiras reações positivas à pintura partiu de uma mulher: Gertrude Stein. Cf. GARB, Tamar. "To kill the Nineteenth Century: Sex and spetatorship with Gertrude and Pablo", in: Les Demoiselles d'Avignon, Green (org.), op. cit., pp. 55-76.

165 "[...] a failure" foi a reação de Daniel Henri Kahnweiler tal como relatada por Richardson, in John RICHARDSON, A Life of Picasso: 1907-1917, vol. 2. Londres: Random House, 1996, p. 34.

166 "An horrible mess", nas palavras de Leo Stein, citado por DAIX, Pierre. Picasso: Life and Art. Nova York: New York Graphic Society, 1993, p. 79.

167 Kahnweiler, citado por DAIX, op. cit., p. 81.

168 O crítico em questão é Félix Féneon. Cf. SECKEL, op. cit., p. 148.

169 BOIS, Yve-Alain. "Painting as a Trauma", in Les Demoiselles d'Avignon, Green (org.), op. cit., pp. 31-54.

170 Rubin, por exemplo, chega a sugerir que o medo e temor de Picasso em relação à doenças venais como a sífilis teriam papel determinante nas disjunções formais de Les Demoiselles, reproduzindo em seu detalhado estudo sobre a pintura uma série de fotografias de rostos assolados pela osteosyphilitis em estado avançado para comparar às prostitutas na obra de Picasso. Cf. RUBIN, op. cit., p. 131. Mas para além de Rubin, muitos autores seguem sublinhando o aspecto "aterrorizante" e "amedrontador' das mulheres na pintura.

171 C.f. FLORMAN, Lisa. "The Difference the experience makes in 'The Philosophical Brothel'", in The Art Bulletin, Vol. 85, No. 4 (Dezembro, 2003), p. 779.W

172 MULVEY, Laura. "O prazer visual e o cinema narrativo", in Ismail Xavier (org.), A Experiência do cinema, Rio de Janeiro: Graal; Embrafilme, 1983, pp. 437-453. 
atenção um pouco adiante. Nesse ínterim, contudo, deixo no ar as indagações: haveria, de fato, um estímulo escopofílico em Les Demoiselles? Será possível pensar na experiência que a pintura proporciona como aquela do prazer ou do gozo visual, que dá sustento às teorias do male gaze? A estrutura da série, ademais, obedece a uma ordem narrativa comparável à do cinema?

A principio, não me parece ser o caso. Trabalhamos em uma zona cinza que torna turvas as afirmações categóricas quando a pintura em questão é Les Demoiselles d'Avignon.

Mas e quanto a Las Meninas?

Confio na hipótese de que nesse caso há, sim, um deliberado estímulo escopofílico na série, um "tratamento onde ternura e violência se tangenciam", uma forma de dirigir o olhar capaz de "jogar com as emoções do espectador" ${ }^{173}$ e incitar sua curiosidade e sua sede de ver.

É provavel que esse deliberado estímulo à pulsão escopofílica do observador em Las Meninas possa explicar parcialmente o porquê das associações feitas no capítulo anterior entre a série de Picasso e os procedimentos de decupagem fílmica. Procedimentos que, curiosamente, voltam a notabilizar-se nas últimas variações da série. Não à toa, Josep Palau i Fabre, poeta e amigo de Picasso, utiliza-se constantemente dos termos zoom e primeiro plano para descrever as pinturas finais da série, que, para ele, são como "visões foto-cinematográficas" ${ }^{174}$.

Durante a realização da pesquisa, tive a oportunidade de passar muitas horas em frente a essas variações no Museu Picasso Barcelona e me dei conta de que quase todos os educadores e guias turísticos recorriam a um vocabulário fílmico para referir-se às pinturas. Em grande parte, pelo modo como certos mecanismos do cinema internalizaram-se em nossas formas de recepção das imagens e mesmo em nossa linguagem verbal, é certo. O que não exclui o fato curioso de que no próprio material educativo da instituição, o zoom em relação aos personagens em primeiro plano seja salientado como característica elementar das obras ${ }^{175}$.

173 PENROSE, Roland. op. cit., p. 497-8.

174 PALAU I FABRE, Josep. El Secreto de Las Meninas de Picasso. Barcelona: Ediciones Polígrafa, 1982, pp. 107-124, 144-145.

175 MUSEU PICASSO Barcelona, Guión Previo para el Profesorado. Disponível em: http:// www.bcn.cat/museupicasso/es/educacion/visitas-dinamizadas.html. Acesso em: 1 de maio de 2019. 
O emprego dessa palavra provavelmente se deve ao fato de que entre uma variação e outra, Picasso joga francamente - e de forma bastante particular - com o ângulo de abertura do campo visual nas pinturas. Tomemos, por exemplo, as variações 45 e 46 (figs.60 e 62). Ambas retratam a infanta e seu séquito, auspiciadas pela sombra de José Nieto ao fundo da composição. Na primeira delas, vemos a princesa e seus acompanhantes em primeiro plano, alinhados horizontalmente de maneira quase retilínea, e tanto esse grupo de figuras como a porta através da qual vemos a silhueta do aposentador parecem mais próximas de nós mesmos que na variação seguinte. Nesta, ainda que o tamanho da tela empregada seja exatamente o mesmo, o espaço parece alargar-se tanto horizontal quanto verticalmente para que possamos ver mais elementos que antes: o par de lamparinas que ilumina a cena, rastros do que na pintura de Velázquez era o reflexo do casal monárquico, vestígios do par de figuras postado atrás do grupo em primeiro plano, uma porção do solo do aposento (agora ocupada pelo cômico cãozinho em frente ao séquito). Para que todos esses elementos entrem em cena, o ângulo de visão a partir do qual a segunda pintura é concebida tem de ser evidentemente maior, o que ocorre às custas de algo bastante peculiar. As figuras em primeiro plano (que antes dispunhamse horizontalmente de forma retilínia) agora convergem a um ponto no eixo central da composição e seu alinhamento passa a obedecer uma distorção elíptica. Ora, não é esse justamente o efeito mais característico de uma lente grande angular? Basta comparar essas pinturas a duas fotografia capturadas desde um mesmo ponto de vista (a primeira, com uma lente retilínea e a segunda, com uma grande angular) para que possamos nos dar conta de que a distorção perspectiva nas pinturas obedece a princípios bastante semelhantes aos das fotografias (figs. 62 e 63), resultando na dilatação de distâncias e na consequente expansão da profundidade de campo.

Tudo se torna mais emblemático se considerarmos que, em seguida, Picasso passa dessas representações do conjunto para retratos individuais de forte apelo dramático que focalizam o rosto de Isabel de Velázco (fig. 66), num movimento que parece obedecer mais às capacidades mecânicas de uma lente fotográfica do que à habilidade de focagem do olho humano. Ao saltarmos de uma pintura a outra, sentimos como se estivéssemos operando um close-up, procedimento que Jean Epstein não hesitou em definir como "a alma do cinema" ${ }^{176}$.

176 Pascal Bonitzer começa seu texto sobre esse recurso no cinema dizendo precisamente: "A fotografia pode ser concebida sem a possibilidade do primeiro plano. O cinema, não: 'O primeiro 
Volto a reiterar que é particularmente instigante, como sinalizamos anteriormente, que aqueles que utilizam-se de Foucault para mediar a relação entre Velázquez e Las Meninas de Picasso não tenham atentado para o fato de que a pintura setecentista, na visão do teórico francês, estabelece uma complexa trama de olhares que desestabiliza a posição fixa do espectador. Em outra ocasião, mas de modo parecido, Foucault demonstrou também como Um bar no Folies Bergère, de Manet, se estabelece a partir de uma rede intrincada de relações visuais, eixos de visão e sinais espaciais que complicam tanto a estrutura interna da pintura quanto a própria posição do espectador em relação à imagem que vê. Já no caso de Las Meninas de Picasso, o ponto de vista móvel em relação à cena é completamente adotado, e é justamente o movimento entre cada uma das variações aquilo que produz a intensidade dramática da série.

Ou melhor, o "ponto de vista móvel" aderido por Picasso em Las Meninas foi sim evocado, mas, como é bastante comum no caso da literatura sobre o artista, ele não foi analisado ou compreendido, mas resgatado. E resgatado do cubismo ${ }^{177}$. Galassi fala de um "modus operandi que Picasso usa em seu ataque para rodear o modelo a partir de todos os lados, submetendo-o a uma análise cubista polivalente" ${ }^{178}$. Ela parece referirse ao cubismo analítico, que, como se sabe, opera, em linhas gerais, a decomposição de objetos em sua volumetria e espacialidade para inseri-los em uma superfície que coloca em tensão a bidimensionalidade e a tridimensionalidade - semelhante a uma espécie

plano é a alma do cinema' [Epstein]". Cf. BONITZER, Pascal. "La métamorphose" Revue belge du cinéma, nº 10, "Le gros Plan", 1984.

177 Uma crítica ao caráter reducionista da abundante literatura sobre a obra de Picasso que resgata o cubismo sempre que se fala de uma multiplicidade de ponto de vistas nos trabalhos dos trabalhos de Picasso a partir 1930, 1940 e 1950 pode ser consultada na sessão "E quanto ao cubismo", em: STEINBERG, Leo. "As Mulheres Argelinas e Picasso em Aberto", in Outros Critérios, op. cit., pp. 197-220.

178 GALASSI, 1996, op. cit., p. 157. Traduzido livremente do original: "The modus operandi that Picasso uses in his attack is to surround the model on all sides, submitting it to a multivalent Cubist analysis". Algo semelhante é afirmado por Karen Kleinfelder: "The labyrinthean dynamics of Picasso's serial imagery map out a shift in orientation that parallels the spatial transformation of Renaissance central perspective by cubism's deployment of multiple perspectives", em KLEINFELDER, op. cit., p. 59. 
de relevo ${ }^{179}$. Mas o processo analítico de Picasso em Las Meninas é totalmente distinto. O que está em jogo não é exatamente o compromisso com a tridimensionalidade da cena, com os volumes ou as perspectivas de simultaneidade, mas sim a maneira como se encadeia uma coleção de pontos de vista recolhidos de uma única imagem bidimensional.

Há, evidentemente, uma concepção espacial que rege cada uma das variações, mas elas são tomadas sempre a partir de uma visada frontal em relação à pintura de Velázquez. A cena, por exemplo, nunca é apresentada em seu reverso, ou desde um ângulo oblíquo ou lateral.

Um material do Ajuntamento de Barcelona, realizado na ocasião da inauguração do Museu Picasso Barcelona em I968 (fig. 60), expõe a questão em termos visuais. Cada uma das variações de Picasso é colocada em relação a Las Meninas de Velázquez para que seja possível visualizar os cortes operados pelo artista. Posto dessa forma, é evidente que uma das principais operações analíticas de Las Meninas é a de selecionar, cortar e enquadrar, proporcionando em uma escala de distanciamento e aproximação o lugar que o espectador ocupa em relação à cena. E, conforme havíamos dito, esses fundamentos estão na base dos procedimentos da decupagem fímica em sua capacidade de "dirigir" o olhar do espectador pelos meandros de uma cena ou situação, jogando com a participação afetiva do público para criar reações emocionais intensas.

179 Nesse sentido, é como se Galassi considerasse a totalidade das variações em simultaneidade, o que se confirma mais adiante em sua análise: "In Velázquez, pictorical and physical space are brought into sharp juxtaposition through the relationship of the painted figures and those implied in front of the painting. Picasso's series extends into real space and time, creating an environment that physically surrounds the viewer". Cf. GALASSI, op. cit., p. 158. Mas sua constatação parece pouco sustentável, não só porque as quarenta e oito pinturas jamais poderiam ser vistas em simultaneidade, mas sobretudo se considerada a própria metodologia escolhida pela autora, que analisa as obras sempre cronologicamente, e nunca pela relação de simultaneidade que estabelecem entre si. 
La composicion original de lelizque
serie de las Meninas de este ultimo.

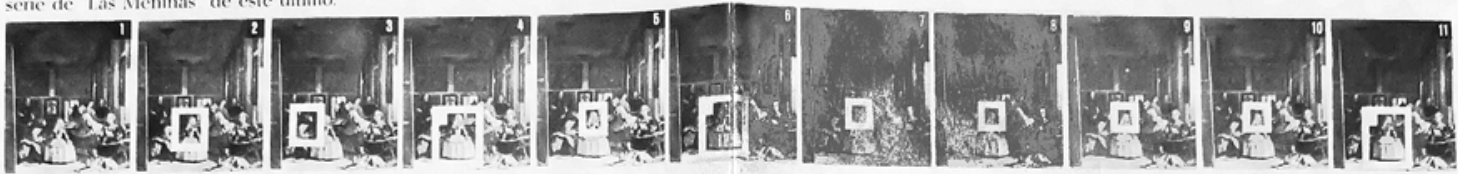

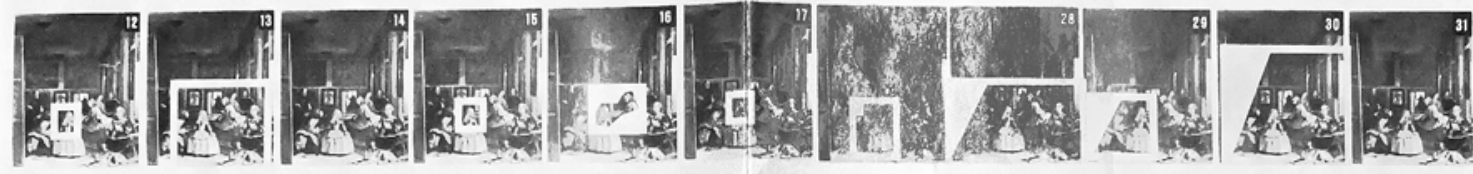

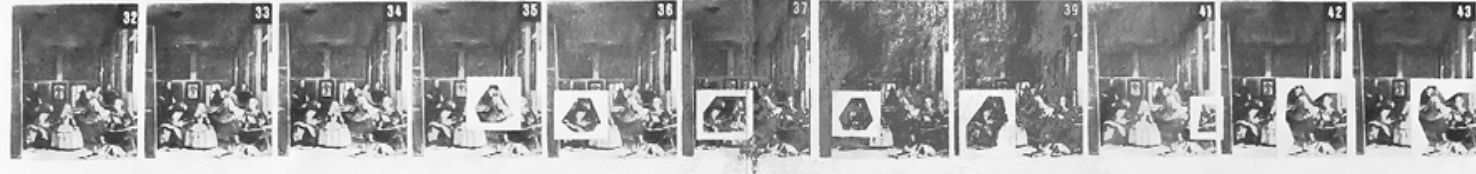



Reproducción de los 44 lienzos de la serie de Picasso en los que se estudia en conjunto o pormenores, la obra de Velázquez.


60 Catálogo da exposição Las Meninas, 1968

Ajuntament Barcelona 

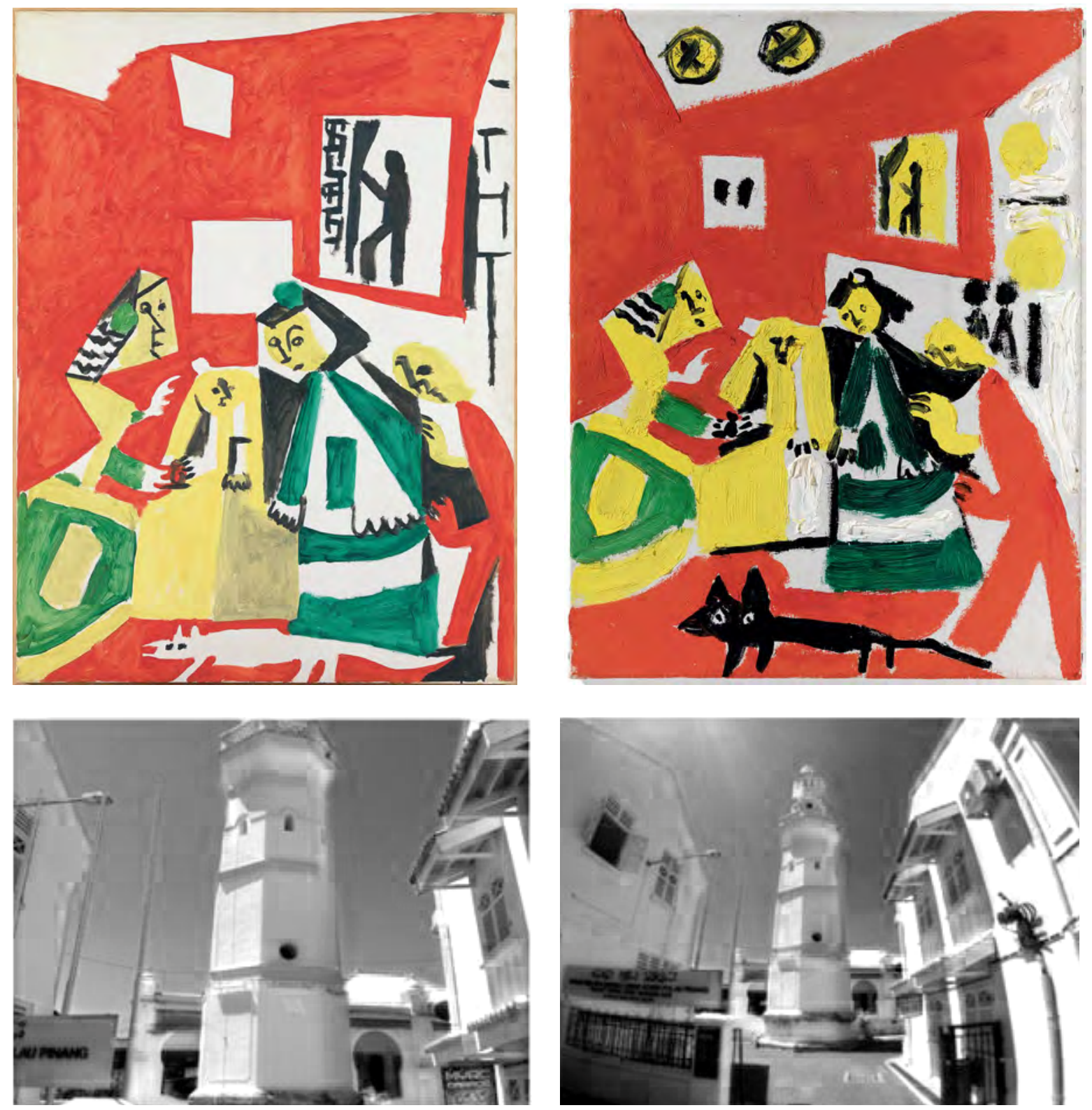

61 Las Meninas

63 Pablo Picasso

Cannes, 15 de noviembre de 1957

Óleo sobre tela

$130 \times 97 \mathrm{~cm}$

Las Meninas

Cannes, 17 de noviembre de 1957

Óleo sobre tela

$35 \times 27 \mathrm{~cm}$

Museu Picasso, Barcelona

Donación Pablo Picasso, 1968

Museu Picasso, Barcelona

62 Lente grande ocular

Fotografia

64 Lente retilínea

Fotografia 

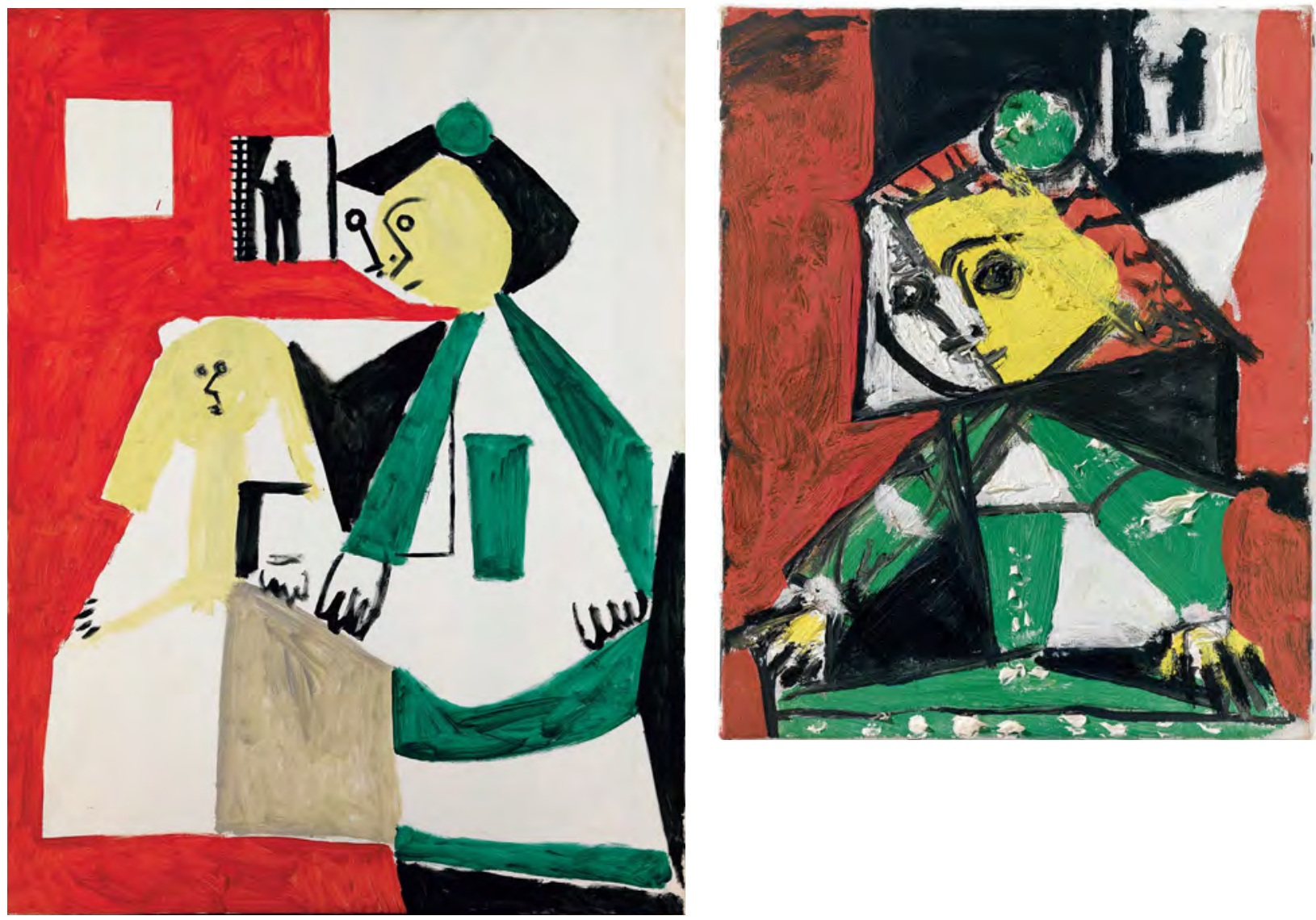

65 Las Meninas [infanta Margarita María e Isabel de Velasco]

Cannes, 15 de noviembre de 1957 Óleo sobre tela $130 \times 96 \mathrm{~cm}$

Museu Picasso, Barcelona

66 Las Meninas [Isabel de Velasco] Cannes, 17 de noviembre de 1957 Óleo sobre tela $27 \times 22 \mathrm{~cm}$

Museu Picasso, Barcelona 


\section{Do ponto de vista feminista}

Não é obra do acaso que a dimensão voyeurística da decupagem clássica tenha sido um dos alvos de denúncia de Laura Mulvey em "O prazer visual e o cinema narrativo", publicado originalmente em I975, uma das primeiras (senão a primeira) abordagens feministas voltadas do conteúdo à forma cinematográfica, isto é, que não se compraziam em questionar a representação da figura feminina em seus papéis instituidos, mas os princípios e modos da representação em si mesmos ${ }^{180}$.

Um dos pontos de partida cruciais do ensaio de Mulvey é o de que o cinema (narrativo) está estruturado, em linhas gerais, por uma configuração de olhares móveis dinâmica e totalmente assimétrica ${ }^{18 \mathrm{I}}$. Para especificá-lo, a autora distingue em três as séries de olhares associadas ao cinema: o da câmera para uma determinada ação ou cena, o olhar do espectador para a tela e os olhares intradiegéticos dos personagens uns para os outros. A dimensão de prazer escopofílico-voyeurista nesse cinema provém precisamente das convenções e hierarquias de linguagem, segundo as quais as duas primeiras séries de olhares (a saber, o olhar da câmera e o do espectador) estão subordinadas e quando não subsumidas à terceira (o olhar dos personagens).

De modo análogo, poderíamos considerar que em Las Meninas de Picasso ao menos três dimensões de olhar estão em jogo: o olhar do espectador, o olhar do artista em relação à obra (de seleção, enquadramento, organização) e a trama de olhares no interior de

180 O ensaio de Laura Mulvey não foi o primeiro texto sobre cinema escrito sob uma perspectiva feminista. As mais antigas manifestações da onda feminista nos estudos de cinema ocorreram com o surgimento dos festivais de cinema de mulheres (em Nova York e Edinburgo) em 1972, bem como com livros populares do começo da década de 1970, como From reverence to Rape, de Molly Haskell ou Popcorn Venus, de Marjorie Rosen. Essa primeira crítica centrava-se sobretudo em objetivos práticos de conscientização e denúncia das imagens midiáticas negativas da mulher. Tomo essas informações de ELSAESSER, Thomas; HAGENER, Malte. Teoria do Cinema: uma introdução através dos sentidos, trad. Mônica Saddy Martins. Campinas: Ed. Papirus, p. 115-6 e STAM, Robert. Introdução à teoria do cinema, trad. Fernando Mascarello. Campinas: Ed. Papirus, 2003, pp. 192-196. Deve-se considerar que o texto de Mulvey é um texto de intervenção, e foi um dos pioneiros para a teoria feminista de cinema. Seu surgimento gerou um debate profícuo, e o texto foi bastante revisitado pela própria literatura feminista, que teceu críticas das mais diversas e muitas delas bastante reflexivas e pertinentes. A própria Mulvey, na esteira desse movimento, procedeu uma espécie de autocrítica, reconhecendo que havia desconsiderado questões importantes. Cf. MULVEY, Laura. "Aftertoughts on Visual Pleasure and Narrative Cinema, inspired by King Vidor's Duel in the Sun". In: Visual and Other Pleasures, Bloomington e Indianapolis: Indiana Univerity Press, 1989, pp. 29-38.

181 MULVEY, 1983, op. cit., p. 452. 
cada uma das variações e entre as variações em sequência. É justamente a urdidura que se entretece entre essas três dimensões do olhar que faz com que Picasso possa jogar com as emoções do espectador, despertando nele uma curiosidade escopofílica.

Há, não obstante, algumas diferenças fundamentais que conferem a essa analogia certo grau de complexidade. A primeira é o fato de que o prazer visual, para Mulvey, só é alcançado na medida em que a câmera cinematográfica opera sob a égide da produção de um espaço realista, ou, para ser mais exata, ilusionista- criando movimentos compatíveis com os do olho humano. A fim de demonstrar como esse espaço ilusionista (que para Mulvey equivale ao da Renascença) está subordinado às necessidades neuróticas do ego masculino, a autora lança mão do conceito lacaniano de estádio do espelho - o momento em que uma criança reconhece sua imagem no espelho, crucial para a construção do ego do sujeito. Para que as convenções e hierarquias do cinema surtam o efeito ilusório de realidade, o espectador deve regressar nostalgicamente àquele momento pré-subjetivo de identificação e fascinar-se pela semelhança e o reconhecimento que as imagens cinematográficas lhe proporcionam. Por isso, a relação entre as figuras humana e os espaços que ela ocupa deve ser sempre antropomórfica, por exemplo.

Evidentemente, nem narrativas, nem realistas (na acepção precisa de Mulvey) e muito menos antropomórficas são Las Meninas de Picasso. Muito pelo contrário, as cores são estridentes, a tinta muitas vezes se faz ver e as figuras são tudo menos naturalistas. A escala das figuras varia bastante entre uma pintura e outra, o que produz uma vertiginosa sensação de redimensionamento - e não só pelos constantes cortes do conjunto ao primeiro plano, mas também pela diversidade de tamanhos de tela utilizadas. Além disso, nem o reconhecimento narcísico e sequer a impressão de continuidade podem aplicar-se à série de Picasso: a sensação de "esquecer o mundo" para entregar-se a uma ilusão particular de realidade simplesmente não acontece.

Ainda assim, isso não é suficiente para invalidar a equivalência entre o olhar voyeurista do cinema narrativo e aquele incitado por Picasso em Las Meninas. Isso porque para Mulvey, o efeito de realidade não é senão um modo de alcançar um mundo complementar de fantasia para que o sujeito (dividido entre a libido e o ego) encontre meio de projetarse sem que por isso tenha que comprometer-se com aquilo que vê. E se é irrefutável que a pretensão a esta ilusão singular de realidade paira longe das quarenta variações de Las Meninas de Picasso, é também difícil negar que o universo de fantasias a ela suplementar esteja absolutamente ausente das pinturas da série. Pois ainda que Las Meninas não seja em si ficcional, ela tampouco está completamente alheia às regras da ficção. 
Recordemos que Roland Penrose, para dar ânimo ao traço caricaturesco da série, evoca Baudelaire e, através dele, o mundo fantástico das gravuras de Goya, com todo seu humor ácido e mordaz. Os mesmos traços caricaturescos (agora, à moda cartoon) estão no cerne do argumento de John Anderson para transferir as operações analíticas de Picasso ao espaço imaginário de uma casa de bonecas onde "[...] distorções, desfigurações, a violação de quaisquer leis morais ou estéticas, a negação de todas as prerrogativas, não têm censura e são legítimas".

A essas duas asserções adiciono as astutas descrições de Michel Leiris, que num dos primeiros escritos sobre Las Meninas denominou as figurinhas nas pinturas de Picasso como "fantasmas de fantasmas ${ }^{182}$ ", "produtos da cultura [...] mas dotados da capacidade de estar aqui como seres vivos" 183 .

O que os três aportes têm em comum (apesar de serem bastante distintos entre si) é o fato de que todos aludem a um universo paralelo contido na realidade para situar Las Meninas de Picasso. No caso dos fantasmas, um universo espectral, de assombrações que estão dentro e fora daquele compartilhado pelos seres humanos. No caso da referência a Goya, um universo fantástico que é a um só tempo distante e alusivo à realidade em suas esferas política e social. E no caso particular da casa de bonecas, um ambiente íntimo em miniatura no núcleo de uma esfera de intimidade, que é capaz de trazer à tona a nostalgia regressiva à infância, a ficção de controle e, em última instância, a vontade de observar em busca de um segredo e desde um ponto de vista exterior e privilegiado. Esse ambiente, conforme demonstrou Susan Stewart ${ }^{184}$, não está privado da projeção da libido, mas é ele mesmo um locus do desejo.

Se, como suspeito, o esforço por inscrever a série de Picasso em uma esfera à parte mas contida na realidade denota também uma vontade do espectador de investir nas figuras caricaturescas de Las Meninas um certo grau de ficção ${ }^{185}$, não é necessário que a série opere

182 LEIRIS, Michel. Un Génie Sans Piédestal et autres écris sur Picasso. Paris: Fourbis Direct, 2011, p. 73.

183 Ibid., p. 78.

184 Cf. STEWART, Susan. On longing: Narratives of the Miniature, the Gigantic, the Souvenir, the Collection. Durhan e Londres: Duke University Press, 1993, p. 61-65.

185 A descrição de Leiris é a que menos se adequa a essa formulação, uma vez que a sua reivindicação de proximidade entre as figuras e os seres humanos também está revestida de um sentido de "familiaridade", em que as esferas entre a ficção e a realidade podem misturar-se. 
sob o preceito da ilusão realista para que o universo complementar de projeção de fantasias exista. Basta que as figuras de Las Meninas, com seus traços caricaturescos e cores intensas, sejam capazes de conduzir o observador a um espaço paralelo para que o olhar escopofílico possa projetar-se ${ }^{\mathrm{I} 86}$. Sob essa perspectiva, talvez fosse mais adequado pensar na série como uma espécie de animação capaz de engendrar no espectador a curiosidade de ver.

Há, de todo modo, mais um ponto que diferencia o olhar do espectador em Las Meninas de Picasso e aquele mobilizado por Laura Mulvey em "O prazer visual e o cinema narrativo". Quando Mulvey distingue aquelas três categorias de olhar da experiência cinematográfica (o olhar da câmera, o do espectador e o dos personagens), o faz para demonstrar que no cinema narrativo as duas primeiras devem subordinar-se ou, quando não, serem suprimidas em favor da terceira - e é justamente essa configuração hierárquica o que viabiliza o prazer visual do espectador. Nos filmes clássicos, a ilusão de realidade deve ser mantida a todo custo e para isso, certas convenções têm de operar. Umas delas é que o olhar dos personagens nunca deve arriscar direcionar-se à câmera, sob a pena de engendrar um efeito desconcertante e inesperado - uma quebra da barreira invisível entre o mundo da ficção e o mundo do espectador, e, por consequência, da continuidade narrativa que garante uma abordagem ilusionista da realidade ${ }^{187}$. Todo o oposto, evidentemente, daquilo que ocorre em Las Meninas de Picasso que, conforme argumentamos, é não só uma série de pinturas em que o olhar das figuras amiúde reconhece a presença do espectador, mas em que o espectador está duplamente exposto pelo confronto com uma testemunha ocular convertida em flagrante.

A transformação do tradicional motivo barroco da testemunha ocular em flagrante desempenha um triplo papel: ela não só provoca consequências simultaneamente ópticas (estereométricas) e dramáticas no interior de cada uma das variações, como é também

186 Não descarto o fato de que se o traço em Las Meninas, como muitos já apontaram, evoca uma linguagem cartoonesca, ele - associado à decupagem - também remete às animações televisivas, que na década de 1950 estavam bastante em voga.

187 Sobre a normatividade que restringe o uso sistemático do olhar direcionado à câmera no cinema narrativo, veja-se: ELAESSER, Thomas; HAGENER, Malte. Teoria do Cinema: uma introdução através dos sentidos, trad. Mônica Saddy Martins. Campinas: Ed. Papirus, p. 114. 
capaz de promover uma quebra na fluidez da série. Não à toa, Picasso explora algumas das potencialidades anti-narrativas que havia levado ao ápice em Les Demoiselles sem eliminar por completo a estrutura narrativa que rege a série. $O$ fato de que as pinturas na série não são capazes de produzir uma ilusão realista talvez faça com que a quebra na fluidez não seja, como no cinema, algo incômodo ou desagradável para o espectador. Mas há, ainda assim, qualquer coisa de aterrador ou espantoso em saber que aquelas figurinhas observam, ou que alguma outra delas nos vê observando-as analiticamente, em tom de escrutínio. Por isso mesmo, Penrose fala de um "humor sombrio" de Picasso na série.

De todo modo, volto mais uma vez ao ponto de partida: se as operações de cortes, enquadramento, aproximação e distanciamento em Las Meninas estimulam uma pulsão voyeurista, elas o fazem de modo a expor sua pedra angular, isto é, a garantia do espectador de ver sem ser visto. O que faz com que a escopofilia - que Laura Mulvey havia definido (na esteira de Freud) como o "prazer de tomar as outras pessoas como objeto, sujeitando-as a um olhar fixo e curioso ${ }^{\mathrm{I} 88^{\prime \prime}}$ - não seja somente mais um dos atrativos das pinturas, mas uma das problemáticas da série em si.

Trata-se de elevar a ficção voyeurista a uma síntese provocativa, e não apenas a explorá-la como condição elementar.

No cinema, curiosamente, o olhar para a câmera - que o modelo hollywoodiano criticado por Laura Mulvey censurava veementemente - passou a ser um traço recorrente nos filmes produzidos durante as décadas de I950 e I960 (quando Picasso realizava suas variações de Las Meninas). Esse olhar frontal e avassalador, que havia se tornado um tabu nos sets de filmagem da época, aparece nos mais diversos filmes, ora como forma de provocar, de desafiar, flertar e seduzir o espectador (Monika e o desejo, de Ingmar Bergman), "ora com o tom mais grave de um olhar que retorna do fundo da história, do além-túmulo, dos horrores da Segunda Guerra, do que é indizível e irrepresentável e, no entanto, nos olha de frente (Noite e nevoeiro e Hiroshima, mon amour, de Alain Resnais), ou com a intensidade frontal da alteridade absoluta, quiçá da loucura (Europa 5I, de Rossellini)" ${ }^{\text {I89. }}$ 
Mas talvez seja em Janela Indiscreta (1954) de Alfred Hitchcock (um dos alvos da crítica de Mulvey, aliás) que esse olhar para a câmera aparece de forma mais paradigmática. O filme (um dos mais discutidos na história do cinema) foi muitas vezes definido como um emblema sobre voyeurismo, uma obra em que o ato de olhar em si é não apenas o "tema" da narrativa como também o ponto nodal da decupagem e da trama. Esse olhar (como muito já se falou e como Mulvey defenderá ${ }^{190}$ ) pode ser visto como um análogo do olhar do espectador em uma plateia de cinema: Jeffries (James Stweart), o protagonista, é um fotojornalista paralisado em uma cadeira de rodas porque tem a perna quebrada devido a um acidente de trabalho - fato que o impele a bisbilhotar, entre uma soneca e outra, os acontecimentos de sua vizinhança em Greenwich-Village através de uma janela (cujo correspondente seria, precisamente, a tela de cinema). Em sua reclusão compulsória, ele é capaz de observar o que ocorre no bloco de apartamentos em frente ao seu através de uma posição semelhante à do espectador de um filme: fixa, distanciada e privilegiada. Na medida em que se põe a observar, começa a desconfiar de um crime cuja existência ele não testemunha mas intui (e talvez até deseje). Tão logo a desconfiança aumenta, uma dimensão erótica é acrescentada a seu olhar - com o qual o espectador se identifica, tanto por sua posição análoga quanto por uma corretude moral.

De fato, as analogias entre tela e janela e entre o olhar do espectador e o olhar do protagonista desde um ponto de vista fixo e privilegiado fazem de Janela Indiscreta uma tentadora metáfora do cinema (sobretudo se considerada uma genealogia que vê a linguagem cinematográfica como um herdeira do modelo epistemológico da câmara escura e da perspectiva clássica).

Entretanto, se o olhar de Jefferies pode ser equiparado ao do observador em uma plateia de cinema, ele pode tão melhor ou mais concretamente vincular-se ao do espectador teatral. Isso porque a mobilidade da câmera faz do espaço representado na tela de cinema um cubo cênico que, à diferença do teatro, pressupõe a existência de quatro paredes. No caso de Janela Indiscreta, para que a analogia entre o olhar do protagonista e o olhar da plateia ocorra, uma dessas paredes deve ser simplesmente oclusa: trata-se da fachada do prédio onde situa-se Jeff, que permanece banida durante quase toda a extensão do filme ${ }^{191}$. Michel Chion fala de uma "foraclusão" da quarta parede, necessária para

190 MULVEY, op. cit., p. 450. A autora extrai a analogia entre Janela indiscreta e o cinema de uma análise do crítico de cinema Jean Douchet.

191 A semelhança entre o cenário de Janela Indiscreta e um espaço derivado do espetáculo 
que a posição privilegiada do espectador seja assegurada. Se os demais apartamentos situados na ala correspondente à do apartamento de Jeffries integrassem a trama do filme, criariam a imagem de uma multiplicidade de focos de visão incongruentes com o requisito de um "espectador ideal". E é justamente a oclusão da quarta parede o que permite que o espaço assuma a "forma imaginária de um cone ${ }^{192 "}$ cujo vértice é o olho de Jeff. Hubert Damisch, ao notar a inexistência da quarta parede na espacialidade criada por Janela Indiscreta, sinaliza que essa configuração particular do cenário confere ao dispositivo fílmico a qualidade de legibilidade de um relevo topográfico, que funciona através de um complexo jogo de articulações entre o espaço tridimensional e bidimensional.

Há um momento no final do filme, entretanto, em que esse sistema que mantinha a quarta parede em recalque é rompido, e a posição aparentemente privilegiada do espectador é revelada. Trata-se, justamente, do momento em que o suposto assassino lança seu olhar à câmera, flagrando Jeffries em sua condição de voyeur. Como esse olhar à câmera coincide também com um plano-ponto-de-vista, ele cruza o olhar do espectador, que, assim como Jeff, é surpreendido em seu ato voyeurista.

Ora, nesse momento - que não é mencionado por Mulvey(nem por Chion) - aquelas três categorias de olhar (o da câmera, o do espectador e o das personagens) se superpõem, configurando um breve instante de desconforto, em que o espectador é desnudado e exposto a si mesmo. Se até então o filme lhe dava a garantia de ver sem ser visto, agora a situação é outra: ele descobre a vulnerabilidade de seu lugar.

Algo semelhante ao que ocorre em Las Meninas de Picasso, em que o espectador é exposto a sua própria sanha voyeurista. Muitos outros são os aspectos que aproximam Janela Indiscreta da série de pinturas em questão: poderíamos citar, por exemplo, a aproximação topográfica de Picasso à cena retratada no quadro de Velázquez, ou o modo como o artista isola detalhes à maneira de um close-up - análogo à forma como Jeffries, no filme de Hitchcock, isola e aumenta as figuras com uma teleobjetiva para focalizar as ações que mais lhe interessam.

teatral foi assinalada por alguns autores. Hubert Damisch atribui a descoberta a Orson Welles. Cf. DAMISCH, Hubert. "Lacoon au cinema 2", in Cinefil, Paris: Éditions du Seuil, 2008, p. 136.

192 Cf. M. CHION, "The fourth side", in Slavoj Zizek (org.), Everything you always wanted to know about Lacan... but were afraid to ask Hitchcock, Londres/Nova York: Verso, 1992, p. 157. 
Uma leitura comparada entre as duas obras, no entanto, foge ao escopo dessa dissertação $0^{193}$. Limito-me a apontar que três anos antes que Picasso realizasse sua própria versão de Las Meninas, Hitchcock havia produzido uma obra que instiga um olhar curioso em toda sua potencialidade para elevá-lo a uma inflexão paradigmática, expondo o ponto cego da ficção voyeurista. Como em Las Meninas, a escopofilia não é apenas mais um dos atrativos do filme, mas uma de suas questões centrais.

\section{O flagrante delito}

Em um texto sobre a teoria do olhar no cinema, Peter Wollen evoca o momento em que o assassino de Janela Indiscreta endereça o olhar à câmera (e, consequentemente, a Jeffries e ao espectador), chamando atenção para sua particular semelhança com as situações descritas pelo filósofo francês Jean-Paul Sartre em seu tratado de ontologia fenomenológica O Ser e o Nada (I943), no capítulo sobre o olhar ${ }^{194}$.

Como Wollen bem observa, as situações evocadas por Sartre têm notável qualidade novelesca e, quando não, cinematográfica:

\footnotetext{
Imaginemos, pois, que por ciúmes, curiosidade ou vício, eu tenha chegado ao ponto de grudar meu ouvido em uma porta ou olhar pelo buraco de uma fechadura. Estou sozinho num nível de consciência não tética de mim [...]. Eis que ouço passos no corredor: alguém me olha. Que significa isso? Fui de súbito atingido em meu ser e surgem modificações essenciais em minhas estruturas. ${ }^{195}$
}

193 Se esse fosse o caso, interessaria abordar a leitura feminista de Tania Modleski sobre Janela Indiscreta, na qual a autora reexamina o seminal ensaio de Laura Mulvey. Cabe sinalizar, de qualquer maneira, que Modleski curiosamente descreve o ambiente criado por Hitchcock como uma "casa de bonecas", da mesma forma como John Anderson havia feito com a série de Picasso. Veja-se: MODLESKI, Tânia. "The Master's Dollhouse: 'Rear Window'". In: The Women who knew too much: Hitchcock and Feminist Theory. Nova York e Londres: Routledge, 2015, pp. 69-89.

194 Cf. WOLLEN, Peter. "On Gaze Theory", in The New Left Review n. 44, (março-abril de 2007), pp. 91- 106.

195 Cf. SARTRE, op. cit., p. 334. 
A criação de uma atmosfera de suspense, a temporalização do olhar, a possibilidade de visualização da cena através de pontos de vista alternados, enfim, várias são as características propriamente cinematográficas dessa passagem. (E todas elas, em princípio, associadas não só ao cinema, mas especificamente ao cinema de Hitchcock).

Tentemos, contudo, entender a situação apresentada por Sartre não apenas como uma passagem novelesca ou cinematográfica, mas no que ela tem de particular. De início, o olhar descrito pelo filósofo parte de um sujeito em primeira pessoa que não é, de forma alguma, um observador desinteressado, mas alguém curioso que se atreve a olhar uma situação que, a princípio, lhe é alheia. Esse olhar obedece mais a um impulso de adentrar em uma circunstância específica, de transgredir as barreiras éticas entre o sujeito e o outro (atente-se, por exemplo, ao que impele o sujeito a fazê-lo: curiosidade, ciúmes, vício), do que a uma vontade de alcançar o conhecimento objetivo. Nesse preciso momento, portanto, o olhar do sujeito não é movido pelo cogito cartesiano ou pela herança de um pensamento que prima pelo acesso à verdade científica, que concebe o olho como órgão que examina, compara, esquadrinha, mede, analisa e separa.

O que não exclui o fato de que seu olhar seja dotado de um poder de objetificação. Tomemos, por exemplo:

\footnotetext{
Minha conexão com essas pessoas que eu espio está dada de relance, fora de mim, como substrato incogniscível da situação que eu mesmo estabeleço [...]. As pessoas que vejo, com efeito, são fixadas em mim como objetos; sou em relação a elas tal como o Outro em relação a mim; ao olhá-las avalio minha potência. Mas, se o Outro vê essas pessoas e me vê, meu olhar perde o seu poder. ${ }^{196}$
}

É claro que esse poder de objetificação (conforme destacará Wollen ${ }^{197}$ ) não é exatamente um legado de Descartes e do racionalismo na filosofia moderna, mas é herdeiro, em grande medida, da dialética hegeliana do senhor e do escravo. Sartre, nas páginas de O ser e o Nada que consagra à interpretação da Fenomenologia do Espírito, atribui a Hegel o mérito de ter feito do outro a condição da consciência de si, o que considerou um passo 
à frente na crítica ao solipsismo - ainda que essa crítica se dê, em Hegel, forma parcial, como Sartre argumentará ${ }^{198}$.

Não pretendo entrar nos detalhes ontológicos e epistemológicos da filosofia de Sartre, mas para o raciocínio que desenvolvo aqui cumpre assinalar que, não obstante reconheça os limites do pensamento de Hegel, Sartre retém em sua concepção de olhar alguns dos termos fundamentais da dialética do senhor e do escravo ${ }^{199}$. O mais evidente deles é a premissa de que o poder de objetificação do olhar não pode ser dissociado de uma relação intersubjetiva na qual o que está em jogo é uma luta pelo reconhecimento e pela liberdade. Em outras palavras, para Sartre, o reconhecimento de si resulta do embate com o outro, em uma relação antagônica em que cada polo limita o seu oposto resistindo-lhe.

Curiosamente, a premissa de que o olhar está intimamente ligado a uma luta por reconhecimento e liberdade é, em grande parte, compartilhada pela crítica feminista no cinema, e especificamente, pela teoria do maze gaze que deriva do ensaio de Laura Mulvey (e que, ademais, adquiriu importância crucial para os estudos feministas no campo disciplinar da história da arte). Nessa vertente crítica, a mesma dialética do senhor e do escravo rege a concepção do olhar, ainda que de forma residual, através de uma separação entre os polos masculino e feminino.

O que pode soar estranho, a princípio, já que o nome frequentemente evocado no caso da crítica feminista em questão é o de Jacques Lacan. Ou nem tanto assim: tenhamos em vista, por exemplo, que Lacan frequentou os seminários de Alexandre Kojève a respeito da Fenomenologia do Espírito de Hegel, impartidos durante sete anos na École Pratique des Hautes-Études, em Paris, entre $1933-1939^{200}$. Consideremos, ainda, que Lacan,

198 Cf. "O obstáculo do Solipcismo" e "Husserl, Hegel e Heidegger", in SARTRE, op. cit., pp. 291-326.

199 Sartre fala do olhar como fonte de escravidão (distinguindo a escravidão daquela que é resultado histórico de uma vida ou de um processo social). Cf. SARTRE, op. cit., p. 344.

Em seu seminal estudo sobre a visão no pensamento moderno francês, Martin Jay reconhece a presença da dialética do senhor e do escravo na concepção de olhar de Sartre, que, segundo o autor, é incorporada através do pensamento de Alexandre Kojève (que tende a priorizar a violência recíproca da oposição dialética ao invés do mútuo reconhecimento). Cf. JAY, Matin. Downcast Eyes: Denigration of vision in Twentieth-Century French Thought, Berkeley: California University Press, 1994, p. 287.

200 Cf. WOLLEN, op. cit., p. 99-100. 
no seminário II desenvolve seu raciocínio discutindo, frequentemente, a noção de olhar em Sartre. E que para além de dados e fatos concretos, Stephen Melville demonstrou como a teoria feminista, ainda que supostamente alicerçada no pensamento de Lacan, amiúde reduziu sua crítica da visão a termos sartrianos, focando-se majoritariamente nas problemáticas da dominação e do reconhecimento sem levar às últimas consequências as esferas do desejo e da linguagem tão caros ao pensamento do psicanalista francês ${ }^{20 I}$.

Em todo caso, ainda que a teoria do olhar em Sartre e o conceito de male gaze tal como desenvolvido por Laura Mulvey coincidam em certos preceitos basilares, há uma notável diferença entre ambos. Ela reside justamente no fato de que o ensaio de Mulvey foca-se sobretudo na relação entre o olhar do espectador e o prazer visual. Sartre, por outro lado, não está interessado na relação entre olhar e prazer; pelo contrário, foca-se sobretudo na relação entre olhar e angústia ou, ainda, entre olhar e vergonha.

Tanto Sartre quanto Mulvey partem de um mesmo ponto, é claro. Não apenas porque concebem o olhar de forma dialética, mas também porque partilham uma série de premissas: a mais evidente delas é a de que o observador deve ter acesso a determinada situação em que ver sem ser visto é a prerrogativa fundamental. Em todas as historietas narradas por Sartre para definir sua concepção de olhar, o sujeito, inicialmente, está (ou crê estar) completamente sozinho, o que lhe garante a possibilidade de tomar o outro como objeto.

Para Sartre, entretanto, essa é apenas uma condição inicial. E o que determina a natureza do olhar é, precisamente, sua inversão. Sartre fala de um sujeito que, no ato de olhar, percebe-se olhado, e, deste modo "deixa de ser o dono da situação ${ }^{202}$ " (ou, mais exatamente, continua sendo o dono da situação, mas passa a ver nela uma dimensão real da qual uma das faces lhe escapa). Por isso mesmo, recorre a acontecimentos narrativos (novelescos ou cinematográficos, conforme se veja) em que o olhar está subordinado a uma dimensão temporal: o que está em questão não é uma categoria estável mais ou menos fixa, mas a transformação de suas estruturas.

Assim, as relações hierárquicas que regem a trama de olhares se desestabilizam, dando lugar a uma experiência intersubjetiva de descentralização do sujeito em sua posição privilegiada. Nas palavras de Sartre: "a aparição do outro no mundo corresponde,

201 MELVILLE, Stephen. "The division of the gaze, or, remarks on the color and tenor of contemporary theory", in Vision in Context, Teresa Brennan e Martin Jay (orgs.), Nova York e Londres: Routledge, 1996, pp. 101-117.

202 SARTRE, op. cit., p. 341. 
portanto, a um deslizamento fixo de todo o universo, a uma descentralização do mundo que solapa por baixo a centralização que simultaneamente efetuo" ${ }^{203}$.

Não fosse o texto de Sartre tão rico em figuras literárias, jamais teríamos uma imagem a tal ponto precisa dessa experiência de descentralização: trata-se de uma "hemorragia interna" em um "mundo que dessangra" 204 . Essa sangria, como se pode imaginar, é algo interno ao sujeito, e não está na ordem do prazer, mas do desprazer. A esse respeito, outra das situações evocadas pelo autor é elucidativa:

É somente provável que, por trás do matagal que se mexe, haja alguém escondido que me espreita. [...] O que capto imediatamente ao ouvir o ranger dos galhos atrás de mim não é a presença de alguém, mas o fato de que sou vulnerável, tenho um corpo que pode ser ferido, ocupo um lugar e de modo algum posso escapar de onde estou sem defesa; em suma, o fato de que sou visto. Assim, o olhar é, antes de tudo, um intermediário que remete de mim a mim mesmo. ${ }^{205}$

Se Sartre insiste na vulnerabilidade do sujeito que se percebe espreitado, ele o faz para enfatizar que o olhar que vem do outro opera, ao fim e ao cabo, uma experiência de descentralização que é pura remissão do observador a ele mesmo.

Sob esta perspectiva, tanto Janela Indiscreta de Hitchcock como Las Meninas de Picasso compartilham um fundo em comum com o pensamento do filósofo francês, pois quando ambos os artistas remontam, como Sartre, a um olhar flagrante, não o fazem de modo a revolver estruturas internas de uma imagem (ou de um filme, no caso de Hitchcock), mas de maneira a abalar a reação subjetiva do observador frente à imagem ${ }^{206}$. Por isso mesmo, é difícil afirmar que Las Meninas de Picasso sejam uma série de trabalhos formalmente inovadores, o que evidentemente não as torna desprovidas de interesse.

203 Ibid., p. 330. Sobre o olhar como experiência de descentralização em Sartre e Lacan, veja-se: BRYSON, Norman. "The Gaze in the Expanded Field", in Vision and Visuality, Hal Foster (org.), Washington: DIA Art Foundation, 1988, pp. 87-115.

204 SARTRE, op. cit., p. 336.

205 SARTRE, op. cit., p. 333.

206 Devo destacar que, em uma brilhante análise da pintura A Sombra, Denis Hollier traz à discussão a relação entre a concepção de olhar de Sartre e a obra de Picasso. Cf. HOLLIER, Denis. "Portrait de l'artiste en son absence - (le peintre sans son modele)". In: Les Cahiers du Musée d 'Art Moderne, XXX, Paris, (Hiver, 1989), pp. $5-22$. 
O que está em jogo em Las Meninas - e também, em certo sentido, em Janela Indiscreta - é tirar proveito da capacidade de dotar um olhar de curiosidade (inchá-lo de uma potência erótica condensada na espreita de um delito, torná-lo ferramenta de análise e escrutínio e mesmo subjugo, explorar ao máximo seu poder de centralização) para, por fim, submetê-lo a uma experiência de descentralização. Nessa empreitada, talvez as coincidências com a situação descrita por Sartre - ou mesmo com o pensamento de Mulvey - não sejam mera casualidade.

A essa altura, chegamos a uma formulação emblemática. Havíamos defendido que um dos pontos que diferenciava a concepção de olhar de Laura Mulvey da de Sartre era, precisamente, o fato de que o olhar, para Sartre, estava associado a uma experiência desprazerosa de descentralização, ao passo que para Mulvey, vinculava-se a uma experiência de prazer visual.

Ainda que esse seja o ponto que os separa, ele é também, paradoxalmente, aquilo que os une. Pois é claro que Mulvey, em um texto de intervenção política, só dedicou tamanha atenção ao prazer visual porquanto pudesse reivindicar a experiência oposta. Isto é, ela estava interessada no lado reverso da moeda: "Diz-se que, ao analisar o prazer, ou a beleza, os destruímos. Essa é a intenção desse artigo ${ }^{207 "}$. Aos consagrados filmes de Hollywood, a autora opunha um cinema "alternativo" que considerava radical, tanto em sentido político quanto em sentido estético.

De certa forma, se Mulvey pôde arbitrar decisivamente pela destruição do prazer visual como ferramenta política na década de 1970 , isso só ocorreu porque tanto Picasso como Hitchcock e, em última instância, Sartre haviam elevado as possibilidades do olhar escopofílico a um ponto de inflexão, trazendo à tona a condição de vulnerabilidade do observador como forma de transformar a experiência do prazer em seu oposto - ainda que de forma pontual. Evidentemente, não digo isso para atribuir-lhes o mérito da crítica feminista e tampouco para designar-lhes o posto de progenitores do que lhes sucederá, mas apenas para situá-los em um mesmo processo histórico de revulsão das premissas do olhar. Cada qual, é claro, dentro de seus limites, que, no caso de Mulvey, foram

207 MULVEY, op. cit., p. 440. 
também o elemento propulsor: "o último lance estremecedor" (quando o que estava em jogo era uma ruptura) só poderia ter vindo de uma mulher.

O processo histórico ao qual me refiro foi brilhantemente estudado por Martin Jay em seu livro Dowcast Eyes: The Denigration of Vision in Twentieth-Century French Tought ${ }^{208}$. O autor argumentará, em linhas gerais, que o pensamento ocidental se desenvolveu ao longo do século XX segundo muitas vertentes que, não obstante as diferenças patentes, mantinham, surpreendentemente, um ponto em comum: a profunda desconfiança em relação à primazia da visão, que se estabeleceu a partir da associação entre lucidez e racionalidade na origem do Iluminismo. Jay considera que a longa tradição oculocêntrica culminou na suspeita generalizada do papel hegemônico da visão como forma de alcançar a verdade. A tese pode parecer espantosa (sobretudo se considerada a longa e consagrada tradição formalista de vertente greenberguiana na base do campo disciplinar da história da arte), mas é justamente o seu caráter paradoxal que lhe dá consistência interpretativa. Segundo Jay, onde a hegemonia da visão se assentava sobre os mais firmes alicerces foi também o palco primeiro de sua derrocada: a França ${ }^{209}$.

No cerne do buliçoso debate público que se instaurou na cultura francesa ao longo do século XX, o pensamento de Sartre desempenha um papel central. E ele é o exemplo por antonomásia de uma visão sob suspeita, de uma obsessão pelo olhar convertida em ameaça - presente tanto em Las Meninas quanto em Janela Indiscreta, ainda que indiretamente. O filósofo francês, conforme relatam muitos de seus biógrafos, era hostil à visão na mesma medida em que era totalmente aficionado pelo olhar: em seus escritos, estima-se que haja mais de sete mil referências ao "olhar" ${ }^{110}$. Um comentador chegou a definir Sartre como "o mais multifacetado dos voyeurs do século" ${ }^{211}$.

208 JAY, op. cit.

209 O que não exclui o fato de que essa mesma desconfiança em relação à visão tenha se espraiado por todo o pensamento europeu. Jay reconhece, por exemplo, a importância do debate ideológico estabelecido nos Cahiers du Cinéma, na França, e sobretudo no pensamento de Christian Metz, para o debate instaurado por Laura Mulvey na Inglaterra. Considere-se também o papel fundamental, por exemplo, que o pensamento de Jacques Lacan e mesmo de Sartre tem na teoria do male gaze. Cf. JAY (1996), op. cit., p. 490.

210 Cf. BUISINE, Alain. Laideurs de Sartre, Lille: Presses Universitaires de Lille, 1983, p. 103.

211 Traduzido livremente de : "The most many-sided voyeurs of the century". Mencionado em JAY, op. cit., p. 276, que refere-se ao original: REDFERN, William F. Paul Nizan: Commited Literature in a Conspiratotial World. Princeton: Princeton University Press, p. 214. 
Ora, é curioso, porém não casual, que Leo Steinberg (um dos mais contundentes exemplares do pensamento que retomou, desde a década de I970, os estudos sobre Picasso desde uma perspectiva renovada) tenha definido o artista como um "argo-voyeur cujos olhos veem a partir de centenas de pontos"212. Se considerarmos, como Jay, que uma visão confiante é capaz de voltar-se contra si mesma, perceberemos também que quanto mais conscientes são os olhos de seu dote de ver sem precedentes, tanto mais admitirão a existência de um ponto cego.

Mas espere. Quando Steinberg fala de um "argo-voyeur cujos olhos veem a partir de centenas de pontos" ele se refere, sobretudo, ao esforço monumental de Picasso por perseguir a estereometria do corpo sem regredir ao ilusionismo pós-cubista ${ }^{213}$, à busca ininterrupta pela forma que satisfaz o impulso erótico, ou, em outras palavras, ao desenho como um "abraço dotado de visão". Trata-se de uma empreitada rumo à invenção de simultaneidades, rumo a uma renovação constante da visão de foco fixo. E também de um compromisso perpétuo com o tema da mulher como realidade sólida. Ou, ainda, da busca pela "omnispecção", que é também uma permanente afirmação de poder ${ }^{214}$.

Trata-se, enfim, de uma concepção de olhar que se afirma através da apreensão do corpo e que é, sem dúvida, bastante mais abrangente que aquela esboçada até aqui. Mas nem por isso diferente. Ao analisar Las Meninas de Picasso, nos focamos menos nas simultaneidades do que em certa dramaticidade em torno das tramas escópicas, que atinge sobretudo ao espectador. Steinberg, todavia, não ignora a relação entre um e outro: ao mapear os tantos recursos mobilizados por Picasso para alcançar a simultaneidade, dedica uma pequena sessão ao uso da "face posterior implicada". Nela, discorre brevemente sobre o apelo a uma figura a média ou remota distância que vê determinada

212 STEINBERG, Leo. "As mulheres argelinas de Picasso em aberto", in Outros Critérios, op. cit., p. 205.

213 Ibid., p. 197.

214 Nas palavras de Steinberg: "Manter seu senso de soberania sobre o que observa exige a invenção de simultaneidades - assim como seu senso de confronto físico com o mundo requer uma renovação da visão de foco fixo. Ele precisa de suas imagens para atestar tanto sua humanidade quanto seu poder de transcender as limitações físicas. E precisa da representação das formas naturais em simultaneidades continuamente renovadas para a reconfirmação perpétua de um poder que existe apenas na medida em que se expande". Ibid., p. 276. 
forma poderosa em primeiro plano. Steinberg alude, portanto, ao que havíamos denominado testemunha ocular, destacando o fato de que Picasso amiúde retém esse "puro modo barroco de sugestão" - quando não com intensão de promover uma ilusão estereométrica, ao menos em sua dimensão dramática.

Nunca é demais ressaltar que, no fim das contas, o olhar "argo-voyeurista" 215 de Picasso é um olhar multifacetado, e que estamos tratando, nessa dissertação, de apenas uma de suas inúmeras faces. Isto é, este trabalho se atém a apenas uma dentre as tantas maneiras que Picasso encontra para testar as capacidades de articulação entre olhar, corpo e campo visual - provavelmente aquela com potencial dramático mais acentuado, diga-se de passagem.

O que em nada significa que seja a menos importante. Quanto à mobilização ao recurso das testemunhas ópticas para dramatizar o olhar, é claro que ele não se dá a ver somente nos anos I950, quando Picasso se propõe a trabalhar sobre Las Meninas. Sabemos que, desde muito jovem, o artista mantinha uma profunda fascinação por retratar situações em que esse tipo de figura entra em questão de maneira evidente. Há algo, no entanto, que não foi enfatizado por Steinberg e que espero que, a essa altura, seja um ponto evidente, ao menos no que concerne Las Meninas: é que, a depender do tipo de engajamento que as imagens mantêm com o espectador, as testemunhas ópticas (em todo seu potencial dramático) convertem-se em flagrantes, tematizando o próprio olhar do observador. De modo que o fascínio de Picasso pelas testemunhas oculares passa a ser não somente uma obsessão pelo alcance da estereometria, mas indica também o interesse por expor uma dimensão voyeurista do olhar do espectador. Mas tampouco isso é algo exclusivo de Las Meninas: em muitas de suas pinturas, do começo ao final da vida, Picasso investiu suas testemunhas oculares de uma ambiguidade constituinte. No capítulo seguinte, pretendo reter-me em algumas obras do fim da vida de Picasso nas quais testemunhas oculares e flagrantes estão amiúde relacionados a um interesse por expor o olhar voyeurista do espectador. Antes, contudo, cabe recordar o fato evidente de que o fascínio pela dramaticidade em torno de situações voyeuristas não é e nem nunca foi interesse exclusivo do artista espanhol. Havia, também, Marcel Duchamp.

215 Ao evocar Argos, Steinberg provavelmente tinha em mente a figura do gigante de cem olhos da mitologia grega, que enquanto dormia mantinha metade de seus olhos abertos para vigiar seu rebanho. A língua portuguesa, hoje, reteve o sentido figurado da palavra: argo, segundo o dicionário Houaiss, significa também espião, agente secreto ou detetive. Ora, talvez esse significado também diga algo a respeito do Picasso de Las Meninas, um artista que analisa, recorta, disseca, investiga e, ao fazê-lo, também espia. 


\section{Capítulo II - O voyeurismo em perspectiva}

\section{E Duchamp? Outra perspectiva em xeque}

Enquanto Picasso produzia sua versão de Las Meninas em Cannes, Marcel Duchamp, do outro lado do oceano, trabalhava confidencialmente na construção de sua última obra, o diorama Étant Donnés: I. La chute d'eau, 2. Le gaz d'éclairage ${ }^{216}$ (figs. 67 e 68). Ao contrário de Picasso que nunca produziu tanto (quantitativamente) como nos últimos anos de vida, Duchamp, desde que decretara incompleta sua obra O grande Vidro, em I924, não fazia questão de negar ou de esconder sua decisão de resguardar-se ao silêncio, o célebre "silêncio duchampiano ${ }^{217}$ ", interrompido esporadicamente por precisas intervenções artísticas e marcado por uma conduta reservada, elegante e discreta ${ }^{218}$. De modo que durante ao menos vinte anos, entre 1946 e I966, enquanto todos suspeitavam que Duchamp havia abandonado a produção plástica para dedicar-se exclusivamente ao xadrez ou para tornar-se um "oculista de precisão" (conforme constava em seu cartão de visitas) $)^{219}$, ele reunia esforços aqui e ali para planejar, preparar e produzir um ambicioso projeto testamentário, uma obra póstuma da qual ninguém - ou quase ninguém - tinha conhecimento ${ }^{220}$. conhecido.

216 Optei por não traduzir o títuto dessa obra, uma vez que o nome em francês é o mais

217 O silêncio de Duchamp foi discutido por muitos autores. Cf. FORGE, Andrew. "The Silence of Marcel Duchamp", Listener, 5 de Novembro de 1959, pp. 775-6/

218 Para informações biográficas, veja-se TOMKINS, Calvin. Duchamp, uma biografia, trad. Maria Thereza de Rezende Costa. São Paulo, Cosac Naify, 2004. Uma breve e precisa reflexão sobre o "silencio duchampiano" pode ser consultada no prefácio da edição brasileira, escrito por Waltercio Caldas.

219 Para a relação de Duchamp com os dispositivos ópticos, consulte-se o terceiro capítulo (sem título) de: KRAUSS, Rosalind. The Optical Uncounciouss, Massachussets: MIT Press, 1993, pp. 95-149.

220 As únicas a saberem do projeto eram Maria Martins e sua esposa Alexina Sattler, (conhecida como Teeny), esta última, fundamental para a execução no Museu de Artes da Filadelfia. 
A "obra secreta" foi montada no Museu de Arte da Filadelfia em 1969, poucos meses após a morte de Duchamp. Não houve solenidade inaugural, comemorações de caráter privado, comunicados de imprensa e tampouco fotografias descritivas, proibidas por imposição do próprio artista. O que em nada impediu, é claro, que a notícia vazasse antes da hora, gerando burburinhos que proliferavam a partir de notícias de jornal deturpadas em escala local, nacional e mundial. Em seguida, multidões foram visitar o museu, apinhando-se para ver a "mais estranha de todas as obras de arte já exposta em qualquer museu do mundo ${ }^{221}$ ", nas palavras de Jasper Johns.

Tratava-se de um diorama em escala ambiental, instalado a poucos metros do Grande Vidro, conforme havia planejado Duchamp. Ainda que as descrições e registros do aparato instalativo montado por Duchamp sejam muitas e pareçam sempre insuficientes, fico com a refinada imagem construída por Octavio Paz:

O visitante cruza uma portinha e penetra num cômodo que se pode considerar pequeno, absolutamente vazio. Nenhum quadro nas paredes de gesso. Não há janelas. Na parede do fundo, embutida num portal de tijolos arrematado por um arco, há uma velha porta carcomida, remendada e fechada por uma tosca trave de madeira cravejada com grossos pregos. No extremo esquerdo superior, há uma janelinha que também foi fechada. A porta opõe ao visitante sua materialidade de porta com uma espécie de altivez: não há passagem. O contrário dos gonzos e seus paradoxos. Uma verdadeira porta condenada. Mas se o visitante se aproxima, descobre dois furinhos à altura dos olhos. Se se aproxima ainda mais e se atreve a bisbilhotar, verá uma cena que não será fácil que esqueça nunca. Primeiro, um muro de tijolo fendido e, através da fenda, um grande espaço luminoso e como que enfeitiçado. Muito perto do espectador - mas também muito distante, no "outro lado" - uma jovem nua, estendida sobre uma espécie de leito ou pira de ramos e folhas, o rosto quase inteiramente coberto pela massa loura dos cabelos, as pernas abertas e ligeiramente flexionadas, o púbis estranhamente limpo de penugem em contraste com o esplendor abundante da cabeleira, o braço direito fora do raio visual do olhar, o esquerdo apenas levantado e a mão empunhando com firmeza uma pequena lâmpada de gás feita de metal e vidro. 

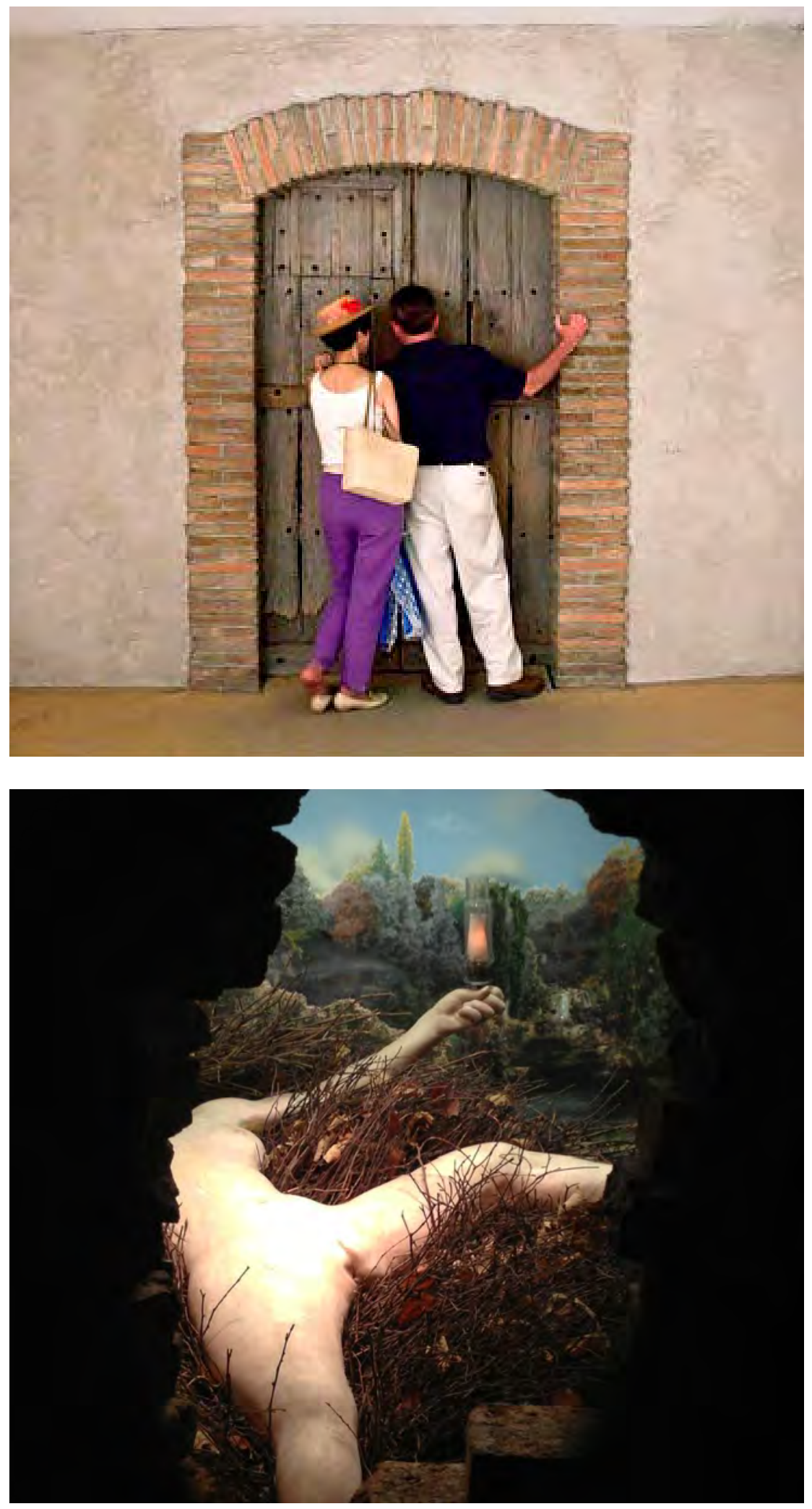

\section{Marcel Duchamp}

Étant Donnés e visitantes, 1946- 1966

Instalação

Museu de Arte da Filadélfia

68 Marcel Duchamp

Étant Donnés, 1946 - 1966

Instalação

Museu de Arte da Filadélfia 
A luzinha pisca em meio à luz brilhante das três da tarde desse imóvel dia de fim de verão. Fascinado por esse desafio ao bom senso - o que há mais claro do que luz? - o olhar percorre a paisagem: no fundo, colinas de abundante vegetação, verdes e avermelhadas; embaixo, um pequeno lago e sobre o lago uma tênue neblina. Um céu inevitavelmente azul. Duas ou três nuvenzinhas, também inevitavelmente brancas. No extremo direito, entre rochas, brilha uma cascata. Quietude: um pedaço de tempo derretido. A imobilidade da mulher nua e da paisagem contrasta com o movimento da cascata e o piscar da lâmpada. O silêncio é absoluto. 222

O inerte e flácido corpo nu, como se sabe, é o de uma boneca, um manequim extremamente realista de dimensões humanas; a porta de madeira, um velho e misterioso portal espanhol. E o espectador, um bisbilhoteiro voyeur. Nas tantas instruções deixadas por Duchamp em 1966 para a montagem de seu diorama, o artista fez constantes referências ao observador utilizando-se precisamente desse termo: voyeur, ele reitera, não espectador, mas voyeur ${ }^{23}$. Não é de se estranhar, portanto, que Octavio Paz termine sua descrição dizendo que "o espectador se retira da porta com esse sentimento feito de alegria e culpabilidade de quem surpreendeu um segredo ${ }^{224}$ ".

Muito já se falou sobre a ambivalência entre deleite e culpa que permeia a experiência de ver Étant Donnés ${ }^{225}$. Ela deriva da reação estupefata do espectador frente à nudez explícita (quando não, obscena) do corpo inerte? Do choque que a imagem por trás da porta é capaz de gerar? Da sensação, como sugere Octavio Paz, de ter surpreendido um segredo? $\mathrm{Ou}$, antes, está associada à possibilidade de ser surpreendido ao espiar um segredo?

222 PAZ, Octavio. Michel Duchamp ou o Castelo da Pureza. São Paulo: Ed. Perspectiva, 1977, pp. 65-66.

223 No manual de instruções para Etant Donné, por exemplo, os buracos na porta são chamados de trou de voyeur. Veja-se DUCHAMP, Marcel. Manual of Instructions: Étant Donnés. New Haven: Yale University Press, 2009.

224 Idem.

225 Stoichita, por exemplo, fala de uma deliberada construção de uma intriga visual que conduz o espectador a satisfazer sua pulsão voyeurística e deflagrar a "cena do crime", estabelecendo um paralelo entre Duchamp e Hitchcock. Cf. STOICHITA, Victor. L'Effet Sherlock Holmes, op. cit., p. 111-117. 
Em uma entrevista com Thierry de Duve, Rosalind Krauss o formula explicitamente: "Eu não sei como vocês se sentiram olhando pelo buraco, mas eu pensei: 'meu Deus, alguém está me vendo fazer isso? Eu nunca me senti desconfortável olhando para qualquer coisa em um museu, exceto nessa vez" ${ }^{226}$.

O desconforto resulta de um cálculo diligente: durante todo o tempo em que o espectador se acomoda na posição estipulada por Duchamp, suas costas estão completamente vulneráveis. Ele pode ser "pego no ato", e, deste modo, ser despido em sua condição de voyeur.

Em um primeiro momento, Duchamp pensava em ser ainda mais explícito quanto a esse ponto. As versões preliminares do diorama previam a existência de um espelho na mão em suspenso do corpo nu estirado, fixado minuciosamente em um ponto que permitisse que o espectador, em conformidade com sua posição determinada, pudesse ver seu próprio reflexo e reconhecer-se enquanto voyeur ${ }^{227}$. Mas isso não foi necessário: a possibilidade de ser visto vendo lograva efeito semelhante, e era suficientemente ou mesmo mais desconcertante.

Pois não é justamente essa possibilidade (de ser surpreendido ao espiar pela fechadura) o que Sartre coloca em evidência no capítulo sobre o olhar em O Ser e o Nada? Rosalind Krauss não deixa de identificá-lo, afirmando que o episódio descrito pelo filósofo francês revela muito sobre Étant Donnés de Duchamp ${ }^{228}$.

226 Traduzido livremente do original: "I don't know how you felt looking through a peephole, but I thought 'My god, who is seeing me doing this? I've never felt uncomfortable looking at anything at a museum except for that". Em: KRAUSS et al., "Discussion", in Thierry de Duve (ed.), The Definitely Unfinished Marcel Duchamp, Halifax: Nova Scotia College of Art and Design, 1991, p. 468. Uma série de entrevistas ao público realizadas no ano em que a obra foi lançada no Museu de Arte da Filadelfia revelam muitos fatores pelos quais os visitantes sentiram-se desconfortáveis. Alguns deles, mais ou menos como Krauss, defenderam que a obra não chocava pela sexualidade explícita, mas pelo sentimento de "ce voyeurisme qu'impliquait le fait de presser son nez contre la porte et de regarder à travers le trou", ou de "regarder sachant qu'il avait quelqu'un derrière vou sen train de vous observer". Citado em TAYLOR, R. Michael. "Le corps dans touts ses états: Étant Donnés de Marcel Duchamp revisité". In: Marcel Duchamp et l'érotisme, Marc Décimo (ed.), op. cit., p. 43, e retirado de: HAAS, Al, "Last Duchamp Is a Real Peepshow", The Philadelphia Inquirer, Filadelfia, 8 de julho de 1939, p. 1 e -. 32.

227 Cf. WITHAM, Larry. Picasso and the Chessplayer: Picasso, Duchamp and the Battle for the Soul of Modern Art. Hannover e Londres: New England University Press, 2013, p. 217.

228 Considere-se, por exemplo: "It is Sartre's chapter on 'The Look' that, inadvertently of course, tells us quite a lot about Duchamp's 'voyeur'.", diz ela. Cf. KRAUSS, The Optical Uncounciouss, op. cit., p. 111. Devo pontuar que a relação entre o olhar do espectador de Étant 
Krauss segue por um caminho particular, todavia: para ela, o que a correspondência entre Sartre e Duchamp demonstra é que a experiência de vulnerabilidade daquele que espia expõe-lhe sua própria existência enquanto corpo. Isto é, ao sucumbir ao desejo de espiar através da abertura da porta, o espectador depara-se com uma impactante cena de nudez, com uma situação em que não ver é simplesmente inevitável, concentrando toda sua atividade no impulso escopofílico induzido. Não obstante, a pressentida possibilidade de ser flagrado enquanto vê revela-lhe sua dimensão corpórea, ilusoriamente neutralizada pela lógica imersiva do dispositivo óptico. Um dispositivo que, não porventura, encontra ressonância numa longa linhagem de instrumentos ópticos destinados a amplificar, direcionar e potencializar a visão, populares tanto na Europa Meridional como no mundo nórdico desde, ao menos, o século XV.

Herdeira, por um lado, desses tantos dispositivos como a camera obscura e as caixas perspectivas holandesas, Étant Donné organiza-se segundo distinções semelhantes às que fundamentam o sistema clássico de perspectiva: trata-se de uma espécie de "máquina" que oferece ao espectador uma cenografia meticulosamente calculada para induzir seu olhar, sem, contudo, consentir-lhe um acesso tátil ao que vê. Dessa forma, estabelece uma separação evidente entre o espectador e a figura observada, designando-lhes uma posição fixa e estabelecida de antemão.

Ainda que o domínio desta "máquina" seja ambiental (e, portanto, tridimensional), o fato de que a cena por ela apresentada só pode ser contemplada através de um par de buracos que respeita a distância entre os olhos do espectador faz com que o acesso que se tem à imagem seja imersivo, e, quando não, bidimensional. Isso porque entre a puída porta de madeira e o lânguido manequim, há uma parede de tijolos irregulares com um buraco central a ser atravessado pelo olhar do espectador, que unifica a binocularidade da visão ao ajustá-la a uma espécie de ponto de vista fixo. E, se o ponto de vista é fixo, o ponto de fuga também: ele é metodicamente calculado para coincidir com a vagina exposta do nu reclinado $^{229}$. Como no paradigma perspectivo, portanto, respeita-se a premissa de identi-

Donnés e a concepção de olhar em Sartre foi posteriormente desenvolvida e discutida por HALADYN, Julian Jason. Marcel Duchamp Étant Donnés, Londres: Afterall Books e University of the Arts London, 2010. Observe-se, ainda, que a relação entre o diorama e a noção de olhar em Sartre é assinalada por Martin Jay: "Without necessary intending it, Duchamp here iniciates the visual interaction explored in existential and phychological terms by contributors to the French antivisual discourse like Sartre and Lacan", in JAY, op. cit., p. 170.

229 Para a discussão sobre ponto de fuga e reflexividade em Étant Donnés, veja-se: 
dade e especularidade entre o ponto de vista e o ponto de fuga. Nesse caso, olhos e vagina.

Krauss, como era de se supor, estava absolutamente ciente dos laços consanguíneos entre o Étant Donnés e o modelo perspectivo. A vasta fortuna crítica a respeito do legado de Marcel Duchamp nunca deixou a desejar no que diz respeito à importância da geometria perspectiva para o pensamento do artista, que, diga-se de passagem, era um grande entusiasta de antigos tratados do século XVII sobre o tema ${ }^{230}$. Uma de suas mais célebres obras da juventude, o Grande Vidro (1923), provou-se um prato cheio para os interessados em encontrar as ressonâncias entre os complexos teoremas perspectivos e os estratagemas duchampianos.

De modo que tão logo Étant Donnés foi lançada a público, não faltaram críticos e estudiosos empenhados em vasculhar suas correspondências com o Grande Vidro, que, como se sabe, havia permanecido "inacabado" por decisão do próprio Duchamp. Por um lado, houve aqueles que se puseram a interpretar a obra póstuma como uma continuação e conclusão, mais de meio século mais tarde, da obra de juventude ${ }^{231}$. No polo oposto, estavam os que viam o diorama negativamente, como uma espécie de antítese ou mesmo como uma paródia vulgar do Grande Vidro. Os admiradores de Duchamp foram os mais propensos a aborrecer-se com a nova peça: para aqueles que exaltavam a maneira como o artista havia subvertido a "arte retiniana", a obra era simplesmente um desapontamento. Robert Lebel, um dos biógrafos mais consagrados de Duchamp (que havia contribuído decisivamente para construir seu prestígio) definiu a obra como uma aventura senil do artista $^{232}$. Críticos de veículos importantes como as revistas Art in America e Artforum

LYOTARD, Jean-François. "Étant donnés, le dernier nu", in: Marcel Duchamp, abécédaire, org. Jean Clair, Paris: Museé National d'Art Moderne et Centre National d'Art et de Culture Georges Pompidou, 1977, p. 86-109.

230 Conforme relata Jean Clair, Duchamp teve acesso ao corpus mais complexo sobre o problema da perspectiva enquanto trabalhava de bibliotecário na biblioteca de Sainte-Geneviève, entre 1913 e 1914. Cf. CLAIR, Jean. Sur Marcel Duchamp et la Fin de l'Art. Paris: Gallimard, 2000, pp. 66-7.

231 Evan H. Turner, o diretor de arte do Museu de Arte da Filadelfia, por exemplo, disse, a repeito do diorama de Duchamp, que ele era "the climax of thoughts he had explored in the Large Glass." Citado em: Michael Taylor, Marcel Duchamp: Étant donnés. Philadelphia: Philadelphia Museum of Art, 2009, p. 149. Para um breve levantamento sobre a recepção crítica de Étant Donnés, veja-se TOMKINS, op. cit., pp. 501-507.

232 As informações foram retiradas de WITHAM, op. cit., pp. 270-272. 
descreveram o diorama como uma obra de "realismo teatral 233 ", ou, ainda, como "um verdadeiro peep-show" ${ }^{234}$ que contradizia muito da produção anterior de Duchamp.

Evidentemente, seria ingênuo desconsiderar que nos referimos à recepção da obra nos Estados Unidos entre o final da década de 1960 e o início da década de I970, em um contexto de ascensão da arte conceitual (que buscava em certa imagem de Duchamp um pilar para suas próprias proposições). Ainda assim, muitos dos postulados por trás de seus principais argumentos seguiram (e, em certa medida, seguem) tendo considerável importância para a fortuna crítica sobre o artista, que, não raro, constrói a imagem de Duchamp como uma personalidade "cerebral", que privilegia a ideia ou o conceito em lugar da matéria ou da forma.

E são precisamente os postulados da imagem em questão que Rosalind Krauss se dispõe a refutar quando dá ênfase à dimensão corporal do olhar em Étant Donnés. Para sustentar seu argumento, partirá do estudo de Jean-François Lyotard sobre a peça, publicado mais de dez anos depois de sua inauguração no Museu de Arte da Filadelfia. Lyotard, em linhas resumidas, definirá Étant Donnés como um dispositivo óptico que reproduz ao pé da letra as hierarquias do sistema clássico de perspectiva, expondo maliciosamente os alicerces subterrâneos que o sustentam ${ }^{235}$. Segundo ele, no diorama de Duchamp, todos os elementos da perspectiva renascentista estão em seu preciso lugar, mas de forma estranhamente literal.

É a deliberada literalidade (e não o realismo) de Étant Donnes, em contraposição à transparência e à hermeticidade do Grande Vidro, o que Krauss considerará, portanto, um elemento crucial. Tomemos, por exemplo, o caso de voyeurismo: a semelhança entre situação provocada pelo diorama duchampiano e a historieta hipotética de Sartre poderia sugerir uma analogia, não fosse a aquela uma versão literal desta ${ }^{236}$. Na peça de Duchamp, já não se trata de imaginar como seria olhar através dos buracos de uma porta, mas de fazê-lo tal e qual.

233 Idem. Traduzido livremente, do original: "Teatrical realism".

234 Idem. Traduzido livremente de: "A real Peep-Show.

235 LYOTARD, op. cit.

236 A literalidade da cena é tão marcante que um autor chega a especular se Étant Donnés não seria uma resposta crítica a O ser e o Nada, publicado em 1943. Cf. HALADYN, Julian Jayson. Étant Fonnees. Londres: Afterall, University of the Arts London, 2010, pp. 101. 
Donde literal é também a experiência de vulnerabilidade do espectador: só verá o que está sendo exposto aquele que se dispuser a debruçar-se frente à velha porta de madeira, virar-se de costas para o espaço expositivo do museu e mergulhar em uma cena que exclui todo o restante à sua volta. Só conhecerá o "segredo" por trás da porta aquele que sujeitar-se ao risco de ser "presa para a intervenção do Outro 237 ". Presa, também, de uma armadilha meticulosamente orquestrada por Duchamp: uma armadilha que, ao reproduzir ipsis lítteris as hierarquias da perspectiva clássica, corrompe um de seus principais postulados, o da visão desencarnada. Isto é, à clássica concepção de olhar enquanto cosa mentale, o diorama duchampiano antepõe a corporeidade do ato de ver, convertendo sua filiação à linhagem perspectiva em impostura e bastardia.

Após esse breve apanhado acerca da recepção e interpretação de Étant Donnés, certas semelhanças e diferenças em relação a Las Meninas de Picasso talvez estejam evidentes, mas cumpre enunciá-las mesmo assim.

Não sem antes, todavia, fazer concessão a uma velha contenda. Não era Picasso o artista que nutria um conhecido desapreço pelo trabalho e pelas proposições de Marcel Duchamp? Muita tinta já foi expendida para responder à questão, de modo que me privarei de uma discussão extensa e pontuarei somente alguns dos fatos mais conhecidos ${ }^{238}$.

Picasso, por um lado, sempre mantivera uma relação de concorrência e admiração com aqueles que considerava seus rivais em matéria de arte, a exemplo de Matisse. Em contrapartida, jamais preservara quaisquer laços de proximidade com Duchamp ${ }^{239}$.

237 "[...] a prey to the intervention of the Other", nas palavras de Krauss, parafraseando Sartre. Cf. KRAUSS, Optical Unconciouss, op. cit., p. 113.

238 Para um estudo recente que acompanha minuciosamente as convergências e divergências das trajetórias de um e de outro, veja-se WITHAM, op. cit.

239 Duchamp era, como se sabe, um pouco mais jovem que Picasso e, portanto, não pertencia exatamente à mesma geração que ele. De qualquer maneira, à medida que os anos passaram, Picasso incorporou artistas mais novos a seu ciclo de relação. É conhecida, por exemplo, sua interlocução com Jean Cocteau ou com Joan Miró. Com relação à sua relação com Cocteau, veja-se: KRAUSS, "Picasso Pastiche", in Os Papéis de Picasso, op. cit., pp 95-205. Sobre a relação entre Picasso e Miró, cf. GREEN, Christopher. "Magicians: Picasso, the Sorcerer; Miró, the monstrous child", in Archictecture and Vertigo, New Haven e Londres: Yale University Press, 2005, pp. 189-225; e COMBALÍA, Victoria. Picasso y Miró: Miradas Cruzadas. Madrid: Electa, 1998. 
E se até meados da década de i9ıo a vanguarda parisiense poderia vir a ser um elo entre ambos, a partir de 1915, quando Duchamp muda-se para Nova York, suas trajetórias parecem tomar rumos completamente distintos. Some-se o fato de que, ao longo dos anos, Picasso nunca fez questão de esconder seu desdém em relação às soluções duchampianas para o trabalho artístico, o que, a partir dos anos 1950 , tornou-se cada vez mais evidente ${ }^{240}$.

Marcel Duchamp, de sua parte, ainda que não manifestasse desprezo pela arte de Picasso, tampouco era um grande entusiasta de seu trabalho. Em larga medida, seu parcial silencio em relação ao tema (à exclusão, talvez, do cubismo) nos leva mesmo a imaginá-lo como alguém indiferente à obra do espanhol. Mas é claro que - dada a fama e o prestígio que Picasso adquirira no meio artístico e cultural a partir, ao menos, da década de $1930^{241}$ e se não antes - a indiferença é também uma posição $0^{242}$.

De todo modo, a história não deixa duvidas quanto à inexistência de um diálogo direto entre a obra de Duchamp e o trabalho maduro de Picasso. Em plano pessoal, dentre os tantos estudos biográficos a respeito de suas vidas, quase todos - se não todos

240 Picasso quase nunca refere-se diretamente ao trabalho de Duchamp, mas em suas falas (por vezes bastante contraditórias), frequentemente coloca-se contrário à arte "cerebral", à arte de "intenções", "conceitos" ou "ideias" Tome-se, por exemplo, suas famosas declarações: "uma ideia é um ponto de partida e nada mais", ou "na arte, as intenções não bastam". Citadas em: CHIPP, H. B. Teorias da Arte Moderna. São Paulo: Martins Fontes, 1999, pp. 265-6. A partir dos anos 1950, devido às próprias mudanças no campo da arte, a atenção de Picasso voltou-se a Duchamp de forma mais clara. Considere-se o relato de Helène Parmelin, que acompanhou o artista de perto nas décadas de 1950 e 1960 e que compartilhava com ele o que Rosalind Krauss definiu como um "desdém [reativo] por Duchamp". Cf. PARMELIN, Helène. Voyage en Picasso. Paris: Robert Lafont, 1980. Em relação à reação de Picasso a Duchamp, veja-se KRAUSS, Optical Unconciouss, op. cit., p. 201-213.

241 Picasso, desde o cubismo e até mesmo antes, já era um artista bastante reconhecido no meio de arte parisiense. Elenco a década de 1930, não obstante, porque é nesse período que a figura de Picasso começa a entrar no frontão da história da arte. Para elencar alguns fatos: em 1932, a primeira grande retrospectiva de Picasso foi organizada na Georges Petit Galerie, em Paris. Foi, ainda, no início da década de 1930 que Christian Zervos publicou o primeiro volume de seu catalogue raisonée da obra de Picasso, que documenta cada trabalho (de desenhos a pinturas) de Picasso e é ainda hoje uma referência para a catalogação da obra do artista. Além disso, foi em 1937 que o Museu de Arte Moderna de Nova York comprou Les Demoiselles d'Avignon.

242 Duchamp se refere algumas vezes à inflacionada fama de Picasso, sem adentrar, especificamente, em um comentário detido a respeito do trabalho em si. Quando, em 1966 (ano em que Duchamp faria 80 anos), Pierre Cabanne o perguntou se, na juventude, havia achado Picasso um artista excepcional, Duchamp respoundeu: "Absolutamente não". E prosseguiu: "Foi mais tarde que Picasso se transformou em uma bandeira. O público sempre precisou de uma bandeira; seja Picasso, Einstein, ou qualquer outro". Cf. CABANNE, Pierre. Marcel Duchamp, o Engenheiro do Tempo Perdido. São Paulo: Ed. Perspectiva, 2012, pp. 40-41. 
- parecem estar de acordo com o fato de que, desde muito cedo, mas sobretudo a partir de certo momento, não havia qualquer interlocução ou interesse mútuo entre ambos. De sorte que, ao propor uma aproximação entre Étant Donnés e Las Meninas, jamais poderíamos supor que seria diferente. Além disso, não custa recordar que Duchamp manteve o planejamento de sua obra póstuma quase que em total segredo, e que, naquele período, Picasso se mantinha cada vez mais restrito a seu próprio círculo em La Californie. $\mathrm{O}$ mais provável é que, entre as décadas de I950 e I960, nenhum dos dois artistas estivesse sequer inteirado do que o outro fazia. Quando muito, lhes alcançava a repercussão da imagem e das exposições do outro na opinião pública, ou através de alguma figura em comum no campo artístico.

Em nada surpreende que, por casualidade, ao saber da morte de Marcel Duchamp em I968, Picasso (que beirava então os oitenta e cinco anos) tenha, sem qualquer constrangimento, decretado um epitáfio que veio apenas a selar aquilo que todos já sabiam: "Ele estava errado" ${ }^{243}$, disse ao ser questionado a respeito da noção duchampiana de "anti-arte".

A essa altura, não obstante, Marcel Duchamp já era considerado por muitos (e quiçá à revelia de Picasso) como figura crucial na história do inacabado século XX - e porventura decisivo no que ainda estava por vir.

Em 1966, quando Paris comemorava ardentemente o aniversário de oitenta e cinco anos do pintor espanhol brindando-o com uma grande exposição retrospectiva no Grand Palais ${ }^{244}$, o crítico de arte Pierre Restany ${ }^{245}$ publicara um texto celebrando o fato de que as novas

243 Traduzido livremente, do original: "Il avait tort". O comentário teria sido proferido após Picasso ter sido questionado a respeito da ideia de "anti-arte" de Marcel Duchamp, e foi retomado por diversos autores. Ele aparece por primeira vez no editorial "Letter From Paris," New Yorker, 2 de Novembro de 1968, p. 173.

244 Conforme relata Witham, a exposição foi um grande sucesso de público. Cf. WITHAM, op. cit., p. 255.

245 O crítico foi um dos árduos defensores do "novo realismo", e o responsável por sintetizar um pequeno manifesto (1961) com os princípios do movimento. Em seus escritos, frequentemente discute a noção de readymade, trazendo à tona o legado de Duchamp para a obra de jovens artistas como Yves Klein, Arman e Jean Tinguely. Além disso, Restany foi também um dos críticos responseáveis por conduzir, nos anos 1960, na França, um debate sobre a produção de arte nos Estados Unidos, focalizando sobretudo aquilo que denominava "neodadaísmo" (Rauschenberg, Jasper Johns e Claes Oldenburg). Ademais, foi importante na discussão acerca das recentes formas de expressão como a performance e os happenings. Alguns de seus escritos podem ser consultados em: RESTANY, Pierre. Os Novos Realistas, trad. Mary Amazonas Leite de Barros, São Paulo: Ed. Perspectiva, 1979. 
gerações teriam se afastado de Picasso - para ele, desde I955. As razões para isso eram muitas: em primeiro lugar, porque Picasso tinha "assassinado a sua própria arte" ${ }^{246}$. Ademais, porque a partir de um certo momento "Picasso copia Picasso", voltando-se constantemente ao passado para criar um "eterno presente que só tem importância para si próprio". A conclusão de Restany é assertiva: “em I960, Picasso já não nos interessa mais, ele pertence ao passado imediato de nossa cultura" ${ }^{247}$. Para as cabeças da arte recente, o novo "mentor moral" ${ }^{48}$ é Marcel Duchamp.

No mesmo ano, a Tate Gallery inaugurava em Londres uma extensa retrospectiva do trabalho de Duchamp - uma grande mostra cujo catálogo sustentava que "nenhum artista vivo é mais respeitado entre as gerações mais jovens do que Marcel Duchamp" ${ }^{249}$. Enfim, na década de I960, talvez o abismo que separava Picasso e Duchamp parecesse, de uma forma ou de outra, um dado incontornável e de crucial importância frente aos impasses e desafios do campo artístico. Caso continuássemos a discussão, restaria indagar em que medida ela terá sido amplificada (não enquanto evidência, mas como atributo de distinção) ao longo das décadas subsequentes, tanto por artistas das gerações seguintes quanto por grande parte da literatura mais influente sobre arte contemporânea, disseminando-se como assunção em escolas de arte, museus e instituições culturais mundo afora.

Mas isso excede em muito o escopo desta dissertação. Para os fins que nos cabem, cumpre, antes, investigar aquilo que uma visão de ambos como pólos opostos de uma antítese pronunciada pode facilmente obliterar ${ }^{250}$. Em outras palavras, interessa exami-

246 Traduzido livremente, do original: "Il a assassiné lui-même son art". Em: RESTANY, Pierre. Arts-Loisirs, Paris, 16-22 de novembro de 1966, n60, p.30 .

247 Idem. Traduzido livremente, do original: "Picasso 1960 ne nous concerne plus, il appartient à l'immédiat passé de notre culture, il a pris sa place dans les histoires et les dictionnaires. Sa propre vitalité tourne à vide ou elle est devenue, si l'on veut, un phénomène purement sociologique : une gymnastique du poignet insérée dans une rigoureuse hygiène de vie."

248 Idem.

249 Traduzido livremente, do original: "No living artist commands a higher regard among the younger generation than Marcel Duchamp.", mencionado em WITHAM, op. cit., p. 244.

250 Quanto a isso, não posso deixar de notar uma questão instigante. Se Picasso e Duchamp são frequentemente vistos como figuras antitéticas, é muito mais frequente a alusão à obra de Picasso por parte da literatura sobre Duchamp do que o oposto. Em boa parte dos estudos sobre Picasso (sobretudo no que concerne à sua obra após a década de 1950), quase não há menção à figura do artista francês. É claro que isso se dá, em grande parte, pelo estatuto e fama que Picasso havia adquirido, pelo fato de ele mesmo ser de uma geração mais velha e, ainda, pela distancia entre ambos. Ainda assim, me pergunto se haveriam outros motivos por trás de tal 
nar o modo com que cada um dos artistas, resguardadas as diferenças, oferece respostas particulares a questões de fundo compartilhado ${ }^{251}$. Questões sobre a visualidade e o olhar que, além disso, terão fundamental importância a partir dos anos de 1970 no campo disciplinar da história da arte.

Para isso, retomaremos Las Meninas de Picasso interrogando os pontos de tangência entre a série e Étant Donnés. Em seguida, consideraremos Las Meninas como um ponto de partida para reexaminar a obra das últimas décadas de vida de Picasso, sem perder do horizonte as possibilidades que uma análise comparativa com a obra Duchamp é capaz de oferecer. Por fim, encerraremos a dissertação buscando reestabelecer o debate que se firmou nos anos de I970 acerca das produções maduras de Picasso e Duchamp, buscando compreender como Las Meninas e, de forma mais abrangente, a obra de Picasso dialogam com os impasses e desafios de seu próprio tempo.

Talvez seja melhor empreender a discussão partindo daquilo que parece mais evidente. O percurso traçado até aqui sugeriria, naturalmente, que aproximássemos Las Meninas e Étant Donnes evocando a presença contundente do olhar flagrante, visando a forma como ambos os trabalhos conduzem o olhar do espectador e estimulam sua vontade escopofílica para, em seguida, introduzir a presença de um outro olhar que atinge o espectador como ameaça, tolhendo-lhe quanto à primazia de sua visão.

No ponto em que estamos, estas devem ser, provavelmente, algumas das coincidências mais visíveis e tentadoras entre as duas obras. Contudo, não é difícil notar que se, por um lado, oflagrante desempenha um papel importante tanto em Las Meninas como

ausência, sobretudo tendo em vista que Picasso quase nunca deixa de constar nos estudos sobre Duchamp. Pergunto-me, ademais, se essa assimetria não seria por si só um indicativo de que um fundo teleológico permanece como fantasma no campo disciplinar da história da arte, ainda que como o reverso da moeda lançada pelo cara ou coroa greenberguiano.

251 O trabalho vem sido feito aos poucos. Philipe Dagen, por exemplo, retoma as figurações do ato sexual na obra madura de Picasso e Duchamp, estabelecendo os pontos de tangência no que concerne à ambiguidade semiótica que permeia na representação do coito. Cf. DAGEN, Philippe. "Étant Donnés Picasso: notes sur une convergence aveugle", in Marc Décimo (org.). Marcel Duchamp et l'Érotisme, Dijon: Les Presses du Réel, 2008, pp. 189-197. 
em Étant Donnés, isso ocorre de maneiras particulares - se não diametralmente opostas. Incontestavelmente a silhueta que interrompe o gozo escopofílico do observador em Las Meninas situa-se no interior do campo pictórico e, por isso, sua relação com esse observador é bastante menos imediata que em Étant Donnés, um diorama instalativo que pressupõe, necessariamente, a implicação corpórea do espectador. Mas será possível considerar efeitos pontuais convergentes quando aquilo que os engendra é de uma natureza completamente distinta? Ou, em outras palavras, estamos, de fato, tratando de uma pintura e de uma peça instalativa como se fossem, a rigor, termos equiparáveis?

De imediato, a comparação periga soar como um aparente disparate, quiçá absurdo quando as obras em questão são Las Meninas (uma série de quarenta e oito pinturas feitas a partir de outra pintura) e, no extremo oposto, Étant Donnés (peça de um artista que declarava abertamente que a pintura estava morta, e por uns bons cinquenta ou cem $\left.\operatorname{anos}^{252}\right)$. Duchamp frequentemente afirmava que aquilo que lhe interessava não poderia ser oferecido pela pintura de cavalete: em I966, por exemplo (quando já havia finalizado Étant Donnés, porém mantinha sua gestação em completo segredo), concedeu uma série de entrevistas ao crítico e jornalista francês Pierre Cabanne, nas quais chegou a assegurar que os recentes happenings lhe agradavam porque introduziram na arte uma experiência de aborrecimento que a pintura não mais era capaz de proporcionar ao espectador ${ }^{253}$.

O que nos leva a crer que, para Duchamp, não se tratava de negar estritamente a linguagem da pintura enquanto tal, mas, sobretudo, de relativizar a potência de que ela dispunha, naquele momento, para provocar determinadas experiências no espectador. E não há como neglicenciar que quando vistas precisamente à luz de tais asserções, as diferenças entre Las Meninas e Étant Donnés tornam-se, de fato, sobrepujantes: verdade seja dita, a série de Picasso teve tímida repercussão imediata, ao passo que o diorama de Duchamp pôde gerar, à maneira de um happening, um quê de aborrecimento em seus espectadores.

Mas por mais distantes que as obras sejam quanto à sua linguagem e ao impacto que causaram, nada exclui o fato de que tanto uma como a outra compartilham, mesmo em suas mais pungentes divergências, uma afinidade em comum - e não no plano dos efeitos

252 Considere-se, por exemplo, a resposta de Duchamp quando Pierre Cabanne the perguntou se o quadro de cavalete estava morto: "Ele está morto no momento e por uns bons cinquenta ou cem anos", cf. CABANNE, op. cit., p. 158.

253 Ibid., p. 167-168. 
que são capazes de engendrar, mas no que concerne à sua estrutura. Refiro-me, sobretudo, ao fato de que ambos os trabalhos assumem como um de seus pontos de partida a existência remota da perspectiva enquanto uma forma que organiza o olhar do espectador.

Ora, pareceria anacrônico supor que por trás dessas obras reside um interesse pelos componentes basilares da antiga ordem perspectiva, não fossem tais componentes apenas reminiscências tácitas de algo a ser posto em xeque. Em outras palavras, não pretendo sugerir que Las Meninas e Étant Donnés partilham dos postulados da perspectiva enquanto forma constituinte, mas somente como um arcabouço de certas condições que permeiam o olhar do espectador.

Rememoremos como isso ocorre no caso específico de Picasso. Mais de vinte anos antes de o debate a respeito da exatidão do ponto de vista de Las Meninas de Velázquez ser despertado pela crítica de Joel Snyder e Ted Cohen, Picasso já havia modificado a organização da composição aqui e ali de forma a explorar, entre outras coisas, a ambiguidade inerente ao lugar ocupado pelo espectador na pintura. De modo que muitos anos mais tarde, sua série é retomada na discussão de Hubert Damisch sobre as origens da perspectiva, na qual o autor a considera como "um documento quase sem equivalentes na história ${ }^{254 " . ~}$

Entretanto, ainda que a organização espacial da obra de Velázquez seja uma constante preocupação de Picasso ao longo da série, ela nunca ou quase nunca é considerada como um elemento crucial na gênese do trabalho: para grande parte dos estudiosos de Las Meninas, dentre os principais fatores que impulsionaram a escolha de Picasso pela obra de Velázquez estavam sobretudo a proximidade afetiva que sentia por seu conterrâneo ou sua vontade de impor maestria frente àquele que considerava um dos grandes mestres da pintura ${ }^{255}$. Tudo isso, aliado a uma nostalgia por sua terra natal, que, segundo seus biógrafos, crescia a cada ano que passava.

O tímido concernimento da literatura em relação à questão da perspectiva talvez se deva, entre outras coisas, ao fato de que em Las Meninas a perspectiva está sempre em

254 "[...] un document à peu près sans equivalent dans l'histoire", em DAMISCH, L'Origine de la Perspective, op. cit., p. 446.

255 Veja-se GALASSI, op. cit; UTLEY, op. cit.. 
jogo, mas nunca é uma questão propriamente dita. Explico-me: quando Damisch defende que Picasso, em composições mais compactas que as de Velázquez, elimina o objeto especular para abrir no fulcro da estrutura pictórica uma "fissura" ou um "buraco branco", ele o faz para demonstrar que Picasso reconhece a proeminência do aposentador que, na composição de Velázquez, ocupa o ponto de fuga geométrico da pintura - em concorrência direta com seu centro imaginário, isto é, o reflexo especular do rei e da rainha.

$\mathrm{O}$ fato de que a silhueta do aposentador coincide, em muitas das variações, com o ponto de fuga da composição de Velázquez não é, contudo, um dado a priori da série, e sim o resultado do processo que ocorre ao longo de seu desenvolvimento: um esboço realizado um dia antes da primeira das variações de Las Meninas $^{256}$ é capaz de certificá-lo de forma vivaz (fig. 69). Trata-se de um pequeno desenho em lápis de cor azul em uma folha de caderno, traçado em linhas precisas e esquemáticas que elaboram a disposição de conjunto e a organização espacial da obra de Velázquez. Desde logo, a proeminência do aposentador se faz ver: se tomadas as dimensões absolutas da folha de papel, ele está situado no eixo mediano da composição e sua cabeça coincide, exatamente, com o ponto central da composição (no cruzamento entre as duas diagonais e a linha mediana). Mas se considerarmos o desenho com base nos postulados da perspectiva (ainda que esse não os cumpra de forma milimetricamente calculada, mas apenas intuída), esse ponto não coincide (como em Las Meninas de Velázquez) precisamente com o ponto de fuga geométrico da pintura: este reside, em um primeiro momento, no espelho que reflete o casal monárquico - justamente no local que muitos dos primeiros estudiosos da pintura de Velázquez acreditavam, de fato, ser o ponto de fuga, mas que, conforme argumentamos no primeiro capítulo, é somente o centro imaginário da pintura. Se prolongarmos as linhas paralelas da fileira de janelas à direita da composição isso se torna bastante visível.

De modo que no desenho preparatório, Picasso localiza os dois centros cruciais da estrutura da obra Velázquez sem, todavia, reproduzir a rigor a espacialidade da pintura original. Se compararmos esse esboço com a primeira variação da série, veremos que entre uma e outra ocorre uma operação fundamental: na pintura, a silhueta do aposentador (que no desenho preparatório localizava-se no centro absoluto do papel) é deslocada à direita, o que faz com que o eixo central da composição passe a cruzar o verso da porta que se abre (como na pintura de Velázquez) e, imediatamente abaixo, as mãos da dama

256 O desenho não integra diretamente o conjunto da série, e foi doado ao Museu Picasso Barcelona posteriormente, em 2009. 


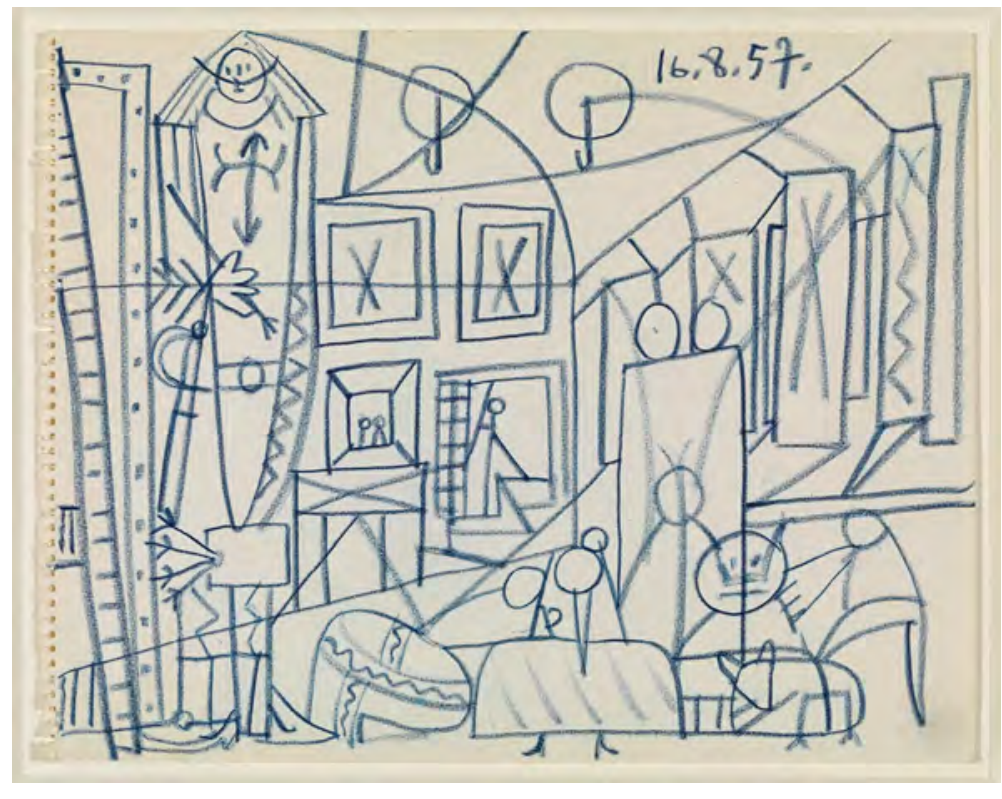

69 Esboço para Las Meninas Cannes, 16 de agosto de 1957. Lápis de color azul sobre papel (folha de caderno)

$24 \times 30,5 \mathrm{~cm}$

Museu Picasso, Barcelona

de companhia que oferece o búcaro à infanta. Com essa alteração, o eixo central passa a localizar-se a meia distância entre o espelho e a silhueta em sombras, e esta última, doravante, passa a ocupar um lugar equivalente ao ponto de fuga geométrico da pintura (ao invés de seu centro absoluto).

Mas atentemo-nos: se o aposentador é deslocado do centro à direita da pintura, como é que ele passa a coincidir com o ponto de fuga geométrico - que, no desenho, claramente localizava-se à esquerda da composição? Pois aí encontra-se o quê da questão: isso é possível somente porquanto o desenho preparatório não admite apenas um ponto de fuga, mas dois. Um deles reside, de fato, no espelho que reflete os monarcas, e o outro, se fosse visível, estaria localizado à direita e para além do campo pictórico. Basta prolongarmos as linhas que delimitam a parede dos fundos do aposento para vermos que elas não são paralelas, mas ortogonais. Se planificássemos o espaço representado em um esquema aéreo, veríamos, portanto, que nesse desenho o espaço do a posento representado não é paralelo àquilo que na linguagem corrente da perspectiva denomina-se o plano do quadro, mas oblíquo.

O que Picasso faz na primeira de suas variações é eliminar o ângulo de obliquidade do espaço do aposento representado em relação à linha do horizonte, transformando o que antes era uma perspectiva que admitia dois pontos de fuga em uma perspectiva frontal, de ponto de vista único. É precisamente por isso que o ponto de fuga passa da esquerda à direita da composição sem que, para isso, seja necessária uma mudança na 
posição das personagens. O que é alterado não é a localização de cada uma das figuras, mas a espacialidade do aposento em relação ao espectador. Dessa forma, Picasso aproxima a espacialidade da pintura àquela apresentada por Las Meninas de Velázquez, que é concebida a partir de uma perspectiva monocular.

Ora, de certa maneira, essa é apenas uma explicação técnica daquilo que Damisch já demonstrou anteriormente, isto é, que Picasso situa na silhueta em sombra o locus de projeção ocular do espectador. E ela parece ainda mais irrelevante se considerarmos que, nas próximas variações, o modelo perspectivo é distorcido com cada vez mais liberdade, de forma que somente o desenho preparatório e a primeira pintura podem ser analisados mais estritamente sob uma ótica geométrica.

Essa mudança, não obstante, sinaliza algo essencial que permanecerá operante ao longo da série: em quase todas as visões de conjunto (à excessão da variação 30), a espacialidade do aposento é tomada a partir de uma visão estritamente frontal, que, em muitos aspectos, deriva do modelo perspectivo da primeira pintura. Essa visada frontal torna-se ainda mais acentuada quando consideradas as variações 3I e 33, nas quais prevalece um espaço repartido em duas porções perfeitamente simétricas cuja saliente divisão é dada por uma linha vertical pronunciada, grossa e escura, fendida pela porta da qual irrompe o aposentador.

Nessas pinturas, a espacialidade se faz tão rígida que, em certo sentido, acaba por afastar-se do modelo de Las Meninas de Velázquez (na qual a posição do espectador é ligeiramente deslocada à direita, de modo a colocar em tensão os diversos centros estruturantes da composição $0^{257}$ ).

Mas eis que ao distanciar-se de Velázquez, Picasso esbarra em outro modelo. Pois a rigidez binária do espaço em profundidade, evidentemente, não é alheia a todo e qualquer antecedente. Recordo: por mais inusitado que pareça, essas pinturas têm o sabor dos "primitivos italianos" que Picasso tanto admirava ${ }^{258}$, ou então o das posteriores anunciações florentinas dos séculos XV e XVI; elas trazem à mente o dispositivo perspectivo

257 Muito se falou de uma espacialidade cubista dessas pinturas. Não vou me deter nesse ponto, pois acredito que as ressalvas que fiz ao longo da dissertação deixam claro que, para mim, não há qualquer compromisso com as perspectivas cubistas de simultaneidade nessa pintura, aliás, pelo contrário.

258 Para a relação entre a invenção do cubismo e o influxo dos primitivos italinos na obra de Picasso, ver KARMEL, Pepe. Picasso and the invention of cubism. New Haven: Yale University Press, 2003, pp. 14-15. 
desses belos retábulos que realçam a divisão do espaço em duas porções opostas para valorizar, no centro da composição, uma abertura que faz penetrar a luz divina.

Talvez seja mais fácil perceber essa insólita correspondência se compararmos, por exemplo, a variação 3I (fig. 70) com o esquema que Joel Snyder e Ted Cohen apresentam para demonstrar o ponto de fuga em Las Meninas (fig. 7Ia) e, simultaneamente, com um pequeno diagrama que Hubert Damisch utiliza para explicitar a construção espacial numa anunciação de Domenico Ghirlandaio (fig. 7Ib). A comparação revela alguns aspectos fundamentais: de início, é possível visualizar que, em um primeiro momento, a frontalização do olhar e a organização perspectiva que acomoda um único ponto de fuga na pintura de Picasso derivam sim da própria organização de Las Meninas de Velázquez, mas são radicalizadas. E radicalizadas em um sentido particular: não de modo a intensificar a ambiguidade estrutural da pintura, senão, pelo contrário, rumo à consolidação de uma divisão binária e rigidamente simétrica do espaço, tirando partido da veemente oposição de suas partes para valorizar, no centro da composição, uma abertura espacial em profundidade, capaz de expressar a tensão entre movimentos colidentes de penetração e irrupção.

Já nos detivemos nesse ponto durante o primeiro capítulo-mais especificamente, sob a ótica dos gestos, poses e olhares de Las Meninas de Picasso e de sua relação com o que Daniel Arasse define como uma "iconografia espacial" da anunciação. Talvez caiba enunciar sumariamente de que se trata essa "iconografia espacial", abstendo-nos das complexidades a ela inerentes, somente para situar-nos diante da inusitada comparação entre as pinturas de Picasso e as anunciações italianas.

O termo "iconografia espacial", em realidade, não foi cunhado por Daniel Arasse, mas foi retomado por ele do seminal artigo de John Spencer, “The Spatial Imagery of Annunciation in Fifteenth Century Florence" ${ }^{259}$, publicado em I955. Nesse artigo, Spencer se dedica a examinar a iconografia italiana da anunciação no século XV com vista às inovações que uma "nova arte" (cujos principais expoentes eram os pintores florentinos Massaccio, Donatello e o escultor e arquiteto Bruneleschi) trazia à espacialidade e à plasticidade da pintura naquele período. Essa "nova arte", cujos postulados viriam a ser formulados em seguida por Leon Battista Alberti, deveria criar um elo emotivo entre o observador e a pintura por meio de um sistema perspectivo capaz de unificar o observador e aquilo que ele vê em um mesmo espaço aparente.

259 SPENCER, John R. "The Spatial Imagery of Annunciation in Feeftenth Century Florece, in The Art Bulletin, Vol. 37, No. 4 (Dec., 1955), pp. 273-280. 
Para os pintores naquele momento, esse modo renovado de representação pictórica impunha um desafio singular à representação do motivo da anunciação. Isso porque, segundo Spencer, a pintura florentina era, no início do século XV, profundamente infundida pelo legado da escola sienesa, ou, especificamente, por soluções iconográficas como as que Simoni Martini havia empregado em sua Anunciação realizada para o altar decorado da Catedral de Siena ${ }^{260}$.

Como, portanto, produzir uma síntese que responda e satisfaça, ao mesmo tempo, o recente modelo perspectivo e essa antiga iconografia da anunciação? Essa é a pergunta que Spencer se faz quando examina o surgimento de uma nova "iconografia espacial" da anunciação no século XV em Florença.

Arasse, por sua vez, retomará o termo proposto por Spencer, deslocando a pergunta por trás dele ${ }^{261}$. Para o historiador da arte francês, o impasse imposto pelo modelo perspectivo à representação da anunciação não apenas diz respeito à unificação espacial, mas também à comensurabilidade. Pois, para ele, o emergente dispositivo da perspectiva impunha ao pintor não somente o repto de unificar o espaço, como também o desafio de fazê-lo segundo as medidas e parâmetros do corpo humano, cujas dimensões estarão sempre determinadas por sua existência terrena no mundo. Isso, por certo, agrega um fator paradoxal à representação da anunciação, que deve estar impregnada de um sentido divino. A anunciação, se considerada segundo o episódio descrito no Evangélio de São Lucas, está intimamente associada à Encarnação da presença divina no corpo da Virgem - a um momento que é por essência incompreensível, indescritível e, sobretudo, incomensurável. Como evocar, através de um sistema de medidas centralizado no humano, a infinita e ilimitada presença divina? Essa é a pergunta que Arasse se faz ao analisar a "iconografia espacial" da anunciação italiana, transformando o binômio entre o "novo" e "antigo" arregimentado por Spencer em uma contradição entre o "mundo comensurável" e a presença "irrepresentável", ou, em outros termos, entre o "manifesto" e o "latente" ${ }^{262}$, entre o "visível" e o "não visível".

260 SPENCER, op. cit., p. 274

261 Cf. ARASSE, op. cit., p. $10-53$.

262 Ibid., p. 11. Cabe destacar que Arasse utiliza expressamente o termo "latente". Considere-se, por exemplo: "Si, en tant qu'elle implique l'Incarnation, l'Annonciation est le moment où l'incommensurable viens dans la mesure, comment la perspective, "forme simbolique" d'un monde commensurable, a-t-elle pu visualiser cette venue (latente) de l'infigurable dans la figure?". 
Mas o que tudo isso, em última instância, tem a ver com Las Meninas de Picasso?

Ainda que a espacialidade das variações da série destinadas a figurar o conjunto não seja concebida, em termos absolutos, segundo a costruzione legittima de Alberti, é inegável que certas coincidências nos trazem de volta a uma questão de perspectiva, e, ulteriormente, ao dispositivo perspectivo tal como posto em prática nas anunciações italianas no século XV. Além disso, diversos outros elementos da série remetem ao episódio da anunciação: recordemos a insistência em perscrutar o gesto entre a infanta e sua dama de companhia. Talvez Picasso tenha visto nesse gesto o mesmo movimento que o poeta, curador e historiador da arte Luiz Perez-Oramas, ao escrever recentemente sobre Las Meninas de Velázquez, associou ao gesto de ajoelhar-se do Anjo $\mathrm{Gabriel}^{263}$; o gesto derradeiro da anunciação.

Recordemos, ainda, as tantas expressões de espanto das figuras, exploradas uma e outra vez ao longo da série. Se voltássemos outra vez à primeira variação da série, reconheceríamos que Isabel de Velázco (a dama de companhia à direita da infanta) é comicamente figurada como se, de sobressalto, gritasse ao ver o espectador. Reconheceríamos também que nessa pintura, a silhueta do aposentador situa-se imediatamente acima da infanta, e que da porta que ele abre jorra um feixe de luz perfeitamente delimitado, que incide precisamente no gesto entre Maria Agustina Sarmiento e a infanta (fig. 72 ). Como não recordar, por exemplo, as tantas anunciações italianas em que o Espírito Santo irrompe na forma de uma pomba ou de um raio de luz, iluminando a virgem ou o gesto entre Gabriel e a Virgem? Ou mesmo dos belos afrescos da escola sienesa (fig. 73) que, através de um jogo entre o espaço tridimensional e o espaço bidimensional "fictício", apresentam Maria e o anjo concretamente separados por um elemento arquitetónico material, isto é, por uma janela "real" através da qual penetra a luz divina?

Divagações à parte, a soma de convergências insólitas nos leva a suspeitar que a série seja, de fato, uma espécie de "Anunciação bizarra", como chegou a sugerir Galassi"264. Ou, melhor ainda, uma Anunciação profana, se considerados, é claro, os traços cartoonescos, as cores gritantes e o tom jocoso das pinturas. Convertendo a pequena infanta em uma sorte de Virgem Maria secular, Picasso faz uso de um puro modo de sugestão que dá vazão a todo o tipo de imaginação acerca do que não está (ou não pode ser) figurado.

263 PEREZ-ORAMAS, Luiz. "El perro y el pie. Nota sobre lo inconcluso", em Dietario, El Nacional, 7 de abril de 2019.

264 GALASSI, op. cit. 




70 Las Meninas

Cannes, 17 de setembro de 1957

óleo sobre tela

$30 \times 161,5 \mathrm{~cm}$

Museu Picasso, Barcelona.

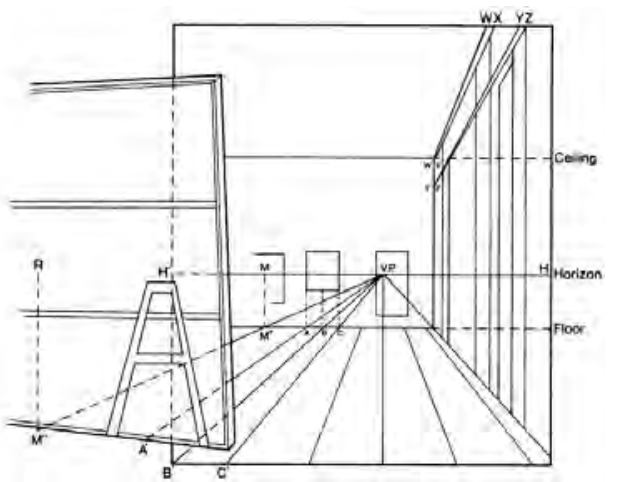

71a Diagrama da perspectiva de Las Meninas de Velázquez



71b Diagrama da Anunciação

de Domenico Ghirlandaio 
Por trás do empréstimo dessacralizado de formas religiosas, subsiste, como nas anunciações italianas, um sistema formal capaz de instaurar no seio da imagem aquilo que não pode ser dito, ou de dar concreção ao que não pode ser representado

Cumpre assinalar, a propósito, que o apelo àquilo que se pressente embora não se veja, ao contrário do que possa parecer, não nega ou anula a existência de um olhar escopofílico por parte do observador da série, característica que vínhamos enfatizando até então. Pelo contrário: a ênfase na suspensão temporal, na dramatização dos gestos, poses e olhares, nas expressões de espanto etc. - isto é, a ênfase em tudo aquilo que engendra o exacerbamento do olhar - é também uma forma de magnetizar o conteúdo latente das pinturas, de tornar operantes as lacunas que permeiam a construção da série. Dito de um modo mais sistemático, Las Meninas de Picasso opera em ao menos dois níveis estruturais: por um lado, se desenvolve por meio de um método serial, fracionado e dissociativo que aposta na insistente perscrutação (e na repetida inspeção) de figuras individualizadas, estimulando o espectador a buscar na gramática disjuntiva de poses e olhares um extrato interpretativo que o permita situar-se frente àquilo que vê e, sobretudo, frente àquilo que não vê, mas é capaz de intuir. Simultânea e inextricavelmente, intercala a essas variações um impactante grupo de pinturas em grande formato, consagradas à representação do conjunto de personagens da pintura de Velázquez. Nessas pinturas, Picasso serve-se de uma estrutura espacial altamente sugestiva, evocando formas remotas para potencializar o olhar curioso e - por que não? - concupiscente do espectador.

Trata-se, enfim, de incorporar e preservar elementos de um sistema para tirar partido de suas consequências e efeitos. Não nos enganemos: a Anunciação nunca será o "significado" último e tampouco o "conteúdo" final de Las Meninas. Pois se Picasso efetivamente incorpora o motivo durante a realização de sua série, não o faz enquanto "tema", mas como um repertório de formas, ativamente mobilizado na articulação da série. Talvez esse seja o grande desafio que a produção de Picasso nos impõe nesses últimos anos de vida: quando o artista elabora suas variações de grandes pinturas da história da arte, não é que esteja resgatando um motivo particular para moldá-lo segundo sua própria mão e seu traço distintivo, como em uma falsa aspiração por incorporar um tema para impor-lhe selo de maestria. Trata-se, antes, da afirmação de acesso inesgotável à história da arte como um catálogo não só de temas, mas também de estilos e formas - muitas vezes, concatenados sob o disfarce de um “conteúdo" facilmente identificável.

Nessa empreitada, não há nada de antagônico em apresentar uma pintura de 
Velázquez na forma de uma anunciação florentina do século XV, pintada em traços cartoonescos e destituída de quaisquer conotações teológicas - ainda que isso implique consequências particulares, evidentemente. Pois na medida em que a Anunciação nos é oferecida em registro profano, somos induzidos a conjecturar se a encarnação também não o seria: nesse caso, estaríamos diante do momento em que a pequena infanta perde a inocência, de uma espécie de desvirginação que nada tem de milagroso ou excepcional. Para que essa intuição seja prognosticada, não é necessário que a pergunta seja efetivamente formulada enquanto tal: se a Anunciação é apropriada enquanto forma dessacralizada, seus efeitos também o serão. Isto é, quando Picasso faz uso da estrutura perspectiva, dos gestos e atributos iconográficos característicos da Anunciação em um tom paródico, conserva apenas seu poder de sugerir a "irrupção" ou "penetração", convertendo o que antes pertencia à dimensão do sagrado em alusão sexual. Basta que o espectador se sinta impelido ao exercício de sua curiosidade visual para que a dimensão lasciva de toda essa empreitada seja adicionada a seu olhar. Volto a reiterar que, não à toa, comentadores viram na série algo como uma "violação" da infanta ou como uma cruel transgressão de leis morais, ainda que violação, crueldade e transgressão não fossem mais que pistas de um faro aguçado.

Um faro que, nesse caso, reconhece que vestígios de um erotismo velado permeiam Las Meninas, mas se mantêm perpetuamente sob tensão, periclitantes, como um nervo à flor da pele. O conteúdo sexual subsiste somente porquanto engastado na forma das pinturas e no olhar do espectador. A irrupção da silhueta em sombra de José Nieto nos dá pistas de sua existência, mas jamais evidências.

Por esse viés, a série mostra-se completamente distinta de Étant Donnés, de Duchamp, na qual tudo é escancarado sem volteios. O espectador, como em Las Meninas, tem também o impulso escopofílico estimulado, mas, desta vez, é explicitamente um voyeur. O dispositivo óptico apresentado compartilha laços sanguíneos com a tradição da perspectiva, e não por acaso é um diorama. O que se vê não é, como em Las Meninas, um conjunto de figuras femininas perscrutadas aqui e ali, mas uma vagina lacerada.

No aparato instalativo de Duchamp, tudo aquilo que Las Meninas de Picasso explora como sugestão - isto é, o flagrante de um olhar voyeurista, as formas da tradição, 

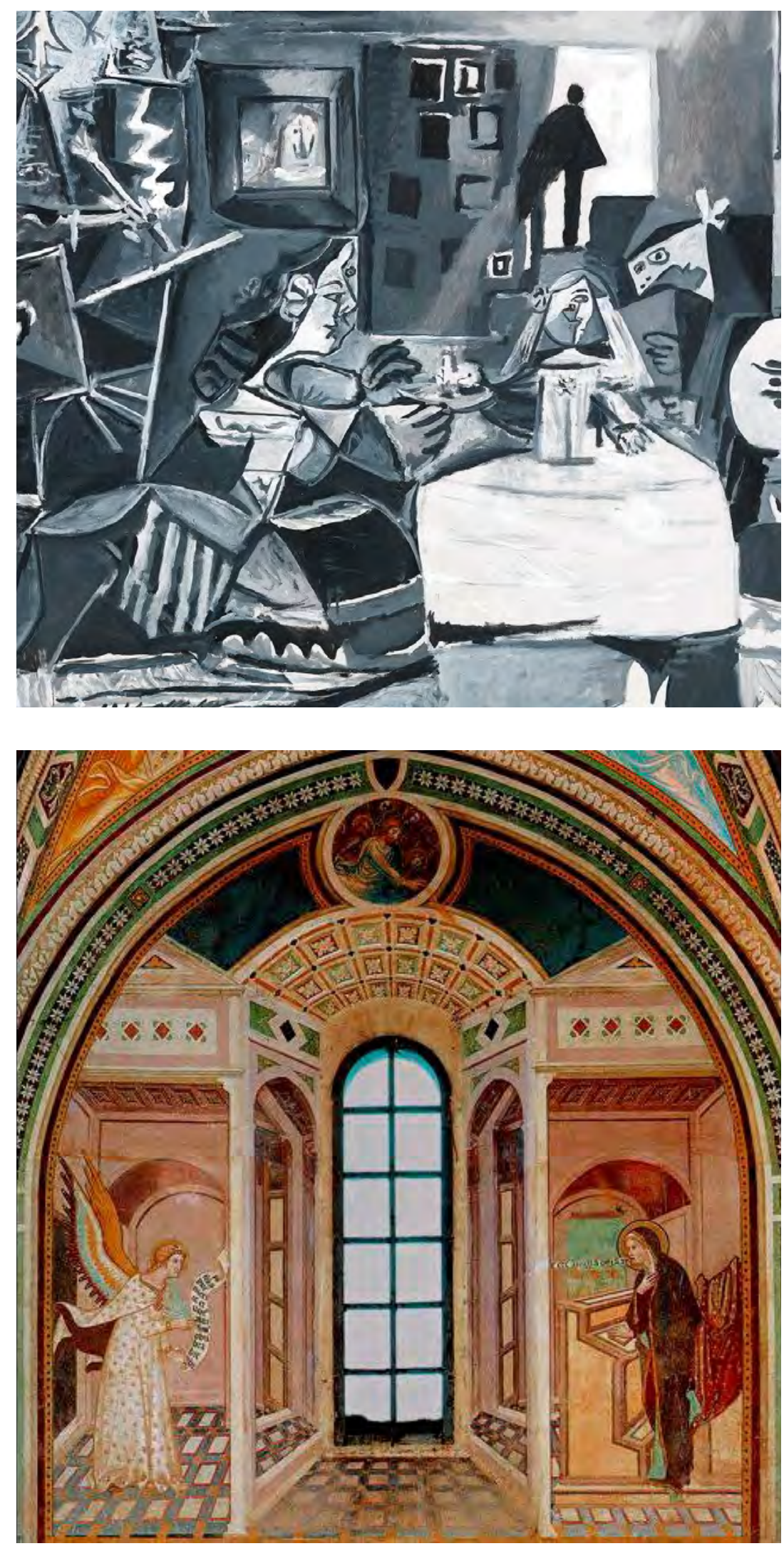

72 Las Meninas (detalhe) Cannes, 17 de agosto de 1957 Óleo sobre tela $194 \times 260 \mathrm{~cm}$

Museu Picasso, Barcelona

73 Lipo Vanni

Anunciação, c. 1365 - 1370

Afresco

San Leonardo al Lago (Siena) 
a conscupiscência do olhar em perspectiva, a exposição da figura feminina - é entregue ao espectador como um conjunto de prescrições incontornáveis. Não é necessário (como em outras obras de Duchamp) nenhum manual de instruções para olhar Étant Donnés: fórmulas matemáticas, enigmas filosóficos e meditações sobre o desejo humano parecem não ter lugar. A obra, como argumenta Krauss, é literal ${ }^{265}$. Tão literal que Michael Taylor, ao escrever sobre o diorama, pôde formular com todas as letras:

Não há a menor dúvida que com este último trabalho, Duchamp planejava pôr em primeiro plano o papel do voyeurismo e que ele renovou a convenção pictórica do ponto de fuga por meio de uma erotização da visão em perspectiva - não mais considerada como inocente ou mesmo científica, mas caracterizada, sobretudo, pela diferença sexual. 266

Tamanha é a assertividade dessa afirmação que somos levados a considerar que quanto mais irretorquíveis as condições que a obra por si impõe, menos devaneios elucubrantes ela gerará. Tudo aquilo que havíamos destacado em Las Meninas de Picasso é, aqui, fato explícito: o voyeurismo, o olhar em perspectiva e erotizado, a diferença sexual implícita no ato de olhar, enfim.

Entretanto, o que Taylor ressalta em Étant Donnés não é de forma alguma um consenso, como se faz parecer, mas fruto de um longo debate gestado no decorrer de anos e que diz respeito, sobretudo, à maneira como a literalidade e o erotismo da obra foram interpretados e articulados pelo público e pela fortuna crítica. Em 20I9, comemoramos cinco décadas desde

265 KRAUSS, 1994, op. cit.

266 TAYLOR, R. Michael. "Le corps dans touts ses états: Étant Donnés de Marcel Duchamp revisité". In: Marcel Duchamp et l'érotisme, Marc Décimo (ed.), op. cit., p. 43Traduzido livremente, do original: "On ne fait aucun doute qu'avec ce dernier ouevre Duchamp prévoyait de mettre au premier plan le rôle du voyeurisme et a rénové la convention picturale du point de fuite au moyen d'une érotisation de la vision perspective qui n'était plus considéeée come inocente, encore moins comee scientifique, mais plutôt caractérisée par la difference sexuel".

Cabe sinalizar que não só Taylor como muitos outros enfatizam que o que mais chama atenção na obra é sua alusão ao voyeurismo. Considere-se, por exemplo: "The most obvious and objectionable aspect of Given is its peephole character: the fact that the viewer is in a voyeuristic position, more akin to carnivals or pornographic shows than to a museum". Em JUDOWITZ, op. cit., p. 196. 
a inauguração do diorama e, como era de se esperar, muita coisa mudou nesse ínterim. E com isso, é claro, a própria forma com que olhamos o trabalho se transformou.

Aqueles familiarizados com a produção de Duchamp possivelmente conhecem fotografias ou descrições detalhadas do diorama sem que necessariamente tenham realizado uma visita ao Museu de Arte da Filadelfia. Os jovens artistas, críticos e historiadores da arte da minha geração hoje têm acesso à obra de Duchamp como um todo: conhecemos o Grande Vidro e Étant Donnés e os demais trabalhos do artista conjuntamente, como parte de uma trajetória unificada, revirada ao longo de meio século pelas mais distintas abordagens.

Sob a pena de soar ingênua, recordo que nem sempre foi assim. Muito da literatura mais consagrada sobre Duchamp foi produzida enquanto ele estava vivo - enquanto ele propositalmente mantinha Étant Donnés em segredo fazendo com que todos imaginassem que sua produção plástica havia chegado ao fim.

Quando a obra foi postumamente inaugurada, não houve grandes alarde, solenidades públicas ou tampouco chamados à imprensa, e fotografias foram definitivamente vetadas ao público por exigência do próprio artista. A atmosfera criada em torno do trabalho era, a um só tempo, de discrição, curiosidade e expectativa. Tratava-se, afinal, do último dos projetos de um artista - agora falecido - do calibre de Duchamp, e para conhecê-lo, era necessário submeter-se à experiência que o trabalho demandava.

Imaginemos que, em um primeiro momento, para um visitante desadvertido (consideradas as condições previstas por Duchamp), o impacto causado pela visão que lhe é apresentada é considerável. Nesse caso, não é de se estranhar que nem mesmo a natureza explícita de Étant Donnés seja coercitiva o suficiente a ponto de tolher por completo a ânsia do espectador em imaginar qual seria, exatamente, a "história" por trás daquele corpo estirado, de pernas abertas e vagina à vista. Sua curiosidade (estimulada) pode ser rápida e efetivamente convertida em um impulso interpretativo.

De fato, uma série de entrevistas realizadas em 1969 com o público do Museu de Arte da Filadélfia confirma que os primeiros visitantes de Étant Donnés amiúde viram no corpo nu aspectos "cadavéricos", definindo-o como algo "repugnante", "pornográfico" e "chocante" e como a possível vítima de um episódio de violência sádica, multilação sexual ou mesmo de violação ${ }^{267}$. A imprensa estadunidense logo veio a corroborar as ruminações 
mórbidas de parte de seu público, redigindo um verdadeiro necrológio para descrever a obra ${ }^{268}$ e polemizar com o "tableau vivant estereoscópico", "porno-trópico" ${ }^{269}$ de Duchamp.

Entretanto, por mais que o espectador saia com a suspeita (não confirmada, evidentemente) de que foi posto diante de uma cena pós-coito ou mesmo de estupro, é unicamente a desnudez o que prevalece enquanto dado tangível. O que nos leva a questionar se a radical literalidade de Étant Donnés não seria, portanto, uma forma poderosa de provocar - ao invés de banir - a curiosidade especulativa do espectador, permitindo-lhe projetar na obra seus desejos particulares. A pergunta é de difícil resposta, mas acredito que seja de grande valia para os esforços de exame comparativo entre Étant Donnés e a obra de Picasso.

É claro que tanto as reações de espanto por parte do público geral quanto a prosa incendiária dos jornalistas de grandes veículos nos Estados Unidos, longe de oferecerem um veredito para a questão, foram apenas respostas iniciais a Étant Donnés(Michael Taylor as define como "epidérmicas" ${ }^{270}$ ), impregnadas por um forte sentido de repúdio à aparência "pornográfica" da obra. Basta um olhar rasante pela história da recepção de alguns dos célebres marcos de nossa cultura para darmo-nos conta de que, no calor da hora, as respostas do público e da imprensa podem amiúde converter-se em um catálogo inesgotável de advertências de cunho moral ou ideológico. O que nada impede que as tomemos como uma espécie de termômetro para aferir certos sintomas - nesse caso, para medir o potencial de rejeição àquilo que a obra apresentava aos espectadores.

Não que um lastro de rejeição à natureza explícita de Étant Donnés tampoucou estivesse, naquele momento, ausente da crítica mais especializada no campo da arte. Como dissemos, a literalidade do diorama incomodou mesmo os fiéis defensores e os maiores entusiastas da produção de Duchamp. Por outros motivos, evidentemente: não pela exposição do conteúdo sexual em si, mas pelo "realismo exagerado" da obra, por sua "obviedade". Arguidores mais hostis não tardaram acusar Duchamp de ter,

268 Veja-se, por exemplo: GRAY, Cleve. "The great espectator", Art in America, vol. 57, no. 4, julio-agosto de 1969, Nova York, p. 20-27.

269 Ibid. p. 42 e retirado de CANADAY, John. "Philadelphia Museum Shows Final Duchamp Work", The New York Times, 7 de julho de 1969, p. 30. Nessa crítica, Canaday relaciona a obra às bonecas prostituídas, deformadas e multiladas do artista americano Edward Keinholz. Michael Taylor, em seu artigo, demonstrará como a relação entre o corpo visto em Étant Donnés e cenas de violência, morte e estupro se perpetuam em descrições da obra até hoje, criticando essa forma de abordagem.

270 Ibid., p. 45. 
surpreendentemente, assinado um decreto "na contramão" da arte moderna, no qual ratificava um "retorno à figuração" ${ }^{271}$. As admoestações, nesse caso, não contestavam o explícito erotismo ou a aberta sexualidade da obra, mas sua promiscuidade figurativa.

No outro polo do debate especializado, intercessores mais amenos buscaram empreender um esforço de visualizar Étant Donnés retrospectivamente a partir do corpus da obra de Duchamp. Alguns, como foi dito, viram o trabalho como uma espécie de "tradução" - e mesmo explicação - do hermético Grande Vidro, como a finalização de uma empreitada que havia permanecido intencionalmente incompleta. O diretor do Museu de Arte da Filadélfia, Evan H. Turner, afirmava que Étant Donnés era o "clímax dos pensamentos que Duchamp havia explorado no Grande Vidro" ${ }^{272}$. John Cage, em uma entrevista, formulou-o com precisão:

Ele gostaria que acreditássemos, eu acho, que Étant Donnés é uma tradução do Grande Vidro - o mesmo trabalho foi reiniciado de uma forma que é muito desconfortável para nós, porque, por um lado, tínhamos crescido aprendendo a gostar da transparência. Em Étant Donnés ele faz exatamente o oposto, nos aprisionando a uma certa distância e removendo a liberdade que desfrutávamos no Grande Vidro. ${ }^{273}$

O raciocínio que confere a Étant Donnés o estatuto de correlato prossecutor ao Grande Vidro se provou, mais tarde, um prato cheio para diversos estudiosos da obra de Duchamp ${ }^{274}$. Por um lado, o Grande Vidro - ou A noiva despida por seus celibatários, mesmo - é

271 O crítico de arte Jeseph Masheck, por exemplo, defende que com Étant Donnés Duchamp se punha "against the grain of modern art". Veja-se MASHEK, Joseph. Duchamp in Perspective, Englewood Cliffs, N.J., Prentice Hall, 1975 p. 23.

272 Traduzido livremente, do original: "the climax of thoughts Duchamp had explored in the Large Glass". Citado em WITHAN, op. cit., p. 271.

273 Traduzido livremente, do original: "He would like us to believe, I think, that the Étant Donnés is a translation of the Large Glass - the same work restarted in a way which is very uncomfortable for us, because we had grown to like transparency for one thing. In Étant Donnés he does the exact opposite, imprisioning us to a particular distance and removing the freedom we had enjoyed in the Large Glass." Retirado de: MOIRA e ROTH, William, "John Cage on Marcel Duchamp," Art in America (November-December 1973), p. 155.

274 Muitas são as analises que voltam-se ao Grande Vidro e a Étant Donnés comparativamente. Elenco, aqui: PAZ, Octavio, op. cit; JOUFFROY, Alain. "Étant Donné Marcel 
uma obra transparente, reflexiva, praticamente bidimensional, abstrata, enigmática, hermética. Para acompanhá-la, Duchamp deixou notas volumosas concebidas para funcionar como um vasto quadro de referências para que o espectador percorresse e decifrasse as múltiplas dimensões da obra. Étant Donnés, em contrapartida, é um dispositivo tridimensional, realista, explícito e corporal, que deveria ser desfrutado sem quaisquer recomendações senão as condições prescritas por sua própria estrutura.

Não obstante, para que Étant Donnés seja a "antítese continuada” do Grande Vidro, os dois trabalhos devem compartilhar um solo comum, a despeito de sua oposição patente. Amelia Jones ${ }^{275}$ nota que ambos tratam de um "observador" e de um "observado", de uma polaridade entre as posições do "feminino" e do "masculino" e da visão erotizada em perspectiva. Jean Clair, por sua vez, sugere que consideremos a cena representada em Étant Donnés como um episódio que sucede, cronologicamente, aquele representado no Grande Vidro: se neste último a Noiva (ou a virgem, conforme consta nos escritos de Duchamp) é representada em um momento imediatamente anterior ao "do gozo que a fará tombar" ${ }^{276}$, em Étant Donnés ela é apresentada no momento post-coitum ${ }^{277}$.

Octavio Paz, por sua vez, observa que no interior do Grande Vidro, Duchamp insere figuras correspondentes a Testemunhas Oculistas, figuras geométricas cuja função, apesar de sua posição marginal, é central. Elas aludem, segundo Paz, "[às] testemunhas que presenciam os milagres nos quadros religiosos e ao voyeur da pornografia ${ }^{278}$ ", e, ademais, remetem ao espectador de Las Meninas de Velázquez. A ubiquidade das Testemunhas Oculistas, para ele, corresponde mais ou menos à dos furos na porta em Étant Donnés: "nesse último,

Duchamp: I) Individualiste Revolutionnaire, 2) Respirateur". In: Opus International, no. 49, Março de 1974, JUDOVITZ, Dalia, op. cit., pp. 195-233, SEIGEL, Jerrold. The Private Worlds of Marcel Duchamp, Berkeley e California: University of California Press, 1997, pp. 86 - 115; CLAIR, Jean. "La Boîte Magique", in Sur Marcel Duchamp et la fin de l'art, Paris: Éditions Gallimard, 2000, pp. 177-286; JONES, Amelia. "Re-placing Duchamp's Eroticism: 'seeing' Étant Donnés from a Feminist Perspective", in Postmodernism and the En-gendering of Marcel Duchamp, Cambridge: Cambrigde University Press, 1994, pp. 191- 205. Para uma análise que complexifica o vínculo entre ambas as obras, veja-se., LYOTARD, op. cit.

275 JONES, op. cit., p. 196.

276 A frase é extraída por Jean Clair dos escritos de Duchamp sobre o Grande Vidro. No original: "avant la jouissance qui la fera déchoir", retirada de SANOILLET, M. (org.). Duchamp du Signe, Écrits de Marcel Duchamp. Paris: Éditions Flammarion, 1975, p. 64 e citada em CLAIR, op. cit., p. 278.

277 Idem.

278 PAZ, op. cit., p. 36. 
o espectador, como as Testemunhas Oculistas, é um voyeur, e assim mesmo, como eles, é uma testemunha ocular, tanto no sentido judicial de achar-se presente no caso, como no religioso que dá fé de uma paixão ou de um martírio ${ }^{279}$. Paz prossegue: "o que nas Meninas e no Grande Vidro é representação, em Conjugação [Étant Donnés] é ato: realmente nos convertemos em voyeurs e também em testemunhas oculares. Nosso testemunho é parte da obra ${ }^{280 "}$. E mais adiante: "Em ambos os casos, não assistimos à violação das virgens mas a seu homólogo: a violação visual" ${ }^{281}$.

(Permito-me fazer um parêntesis de apelo para que notemos o quanto a descrição de Paz revela que ambas as obras, resguardadas as diferenças, compartem também certos pontos em comum com Las Meninas, de Picasso. Curiosamente, Octavio Paz recorre tanto à figura da virgem na pintura religiosa quanto a Las Meninas de Velázquez para construir sua interpretação da obra de Duchamp).

Esses e tantos outros são os paralelos que levaram estudiosos a interpretar a figura vista em Étant Donnés como a de uma "noiva imediatamente desvirginada" - como se ela fosse, de fato, a versão literal da figura feminina do Grande Vidro - e a argumentação, em muitos casos, é bastante convincente. Mas ainda que admitamos que Étant Donnés seja, efetivamente, um alter ego $^{282}$ literal do Grande Vidro, isto é, mesmo que consideremos que a literalidade seja uma escolha formal do trabalho, resta questionar como interpretá-la enquanto fato. Dada a existência de uma vasta e nuançada literatura a esse respeito, me limitarei a comentar dois casos paradigmáticos que se voltam à questão por vias acentuadamente divergentes (e senão opostas) entre si.

De um lado, reações hostis à literalidade de Étant Donnés jamais deixaram de existir, mesmo entre os que estavam prontamente dispostos a avalizar a filiação entre essa obra e o Grande Vidro. Na década de I990, decorridos mais de vinte anos após o abalo sísmico causado pela inauguração do diorama no Museu de Arte da Filadélfia, o historiador estadunidense Jerrold Seigel declarou em alto e bom tom sua assertiva rejeição

\footnotetext{
279 Idem.

280 Ibid, p. 87.

281 Ibid, p. 91.
}

282 A definição de Étant Donnés como alter ego do Grande Vidro foi forjada por Anne d'Harnoncourt e Walter Hopps, os primeiros a escrever sobre a obra. Cf. D'HARNONCOURT, Anne, HOPPS, Walter. "Etant Donnés: $1^{\circ}$ la chute d'eau $2^{\circ}$ le gaz d'éclairage: Reflections on a New Work by Marcel Duchamp" in Philadelphia Museum of Art Bulletin, Vol. 64, (Apr. - Sep., 1969), 5-58, p. 8. 
à "falta de imaginação", ao "realismo figurativo" e à "natureza terrena" de Étant Donnés. Seu juízo da obra póstuma de Duchamp, no entanto, não era - como nos porta-vozes da pugna desencadeada no calor da hora - a expressão de uma conduta retaliativa em relação à figura do artista ou em relação aos rumos que o diorama selava à sua produção. Pelo contrário: retomando as primeiras sentenças negativas de amigos e admiradores de Duchamp a este trabalho - em parte para corroborar com elas, em parte para historicizá-las -, Seigel defende que a exagerada literalidade de Étant Donnés não poderia ser meramente o sinal da senilidade de seu autor, ou tampouco o indício de uma reviravolta radical em relação à postura anti-arte que marcara sua trajetória nos últimos anos. Mas por que então Duchamp teria, em sã consciência, desprendido tanto esforço e durante tanto tempo em um projeto literal como esse ${ }^{283}$ ? "Qual é mensagem"? ${ }^{284}$.

Trata-se, para Seigel, de uma espécie de "ensinamento", ou de contra-ensinamento póstumo, de "um exemplo do que, para Duchamp, a arte não deveria ser", de atitude que integra uma estratégia autobiográfica "irônica e enigmática de dizer em que consistia seu trabalho inicial" ${ }^{285}$. Asseverando a progênie antitética entre o Grande Vidro e Étant Donnés e confiando plenamente na predileção do artista pelas soluções do primeiro em relação ao último, Seigel defende que Duchamp dificilmente teria devotado tamanho afinco à realização do diorama "caso não considerasse essa obra como algo essencial que diz respeito ao que ele estava tentando realizar em sua vida". Isso explicaria por que o artista não parava de querer arranjar, para sua nova instalação, uma posição muito próxima ao Grande Vidro no Museu de Arte da Filadélfia ${ }^{286}$.

Essa afirmação, de prontidão, levanta suspeita. Por que atribuir tamanho didatismo à operação de Duchamp quando sua obra nunca esteve exatamente às voltas com morais instrutivas e lições pedagógicas?

283 SEIGEL, op. cit., p. 112-115.

284 ibid., p. 112. Traduzido livremente, do original: "But as others recognized, Duchamp would hardly have devoted so much effort to such a work had he not regarded it as saying something essential about what he had been trying to accomplish in his life. What message?".

285 Considere-se, por exemplo: "Everything adds up to let us know that the work Duchamp produced over twenty years but kept hidden while he lived is his account of just what art should not be, it's the world of the Large Glass destroyed by being finished off, the ending he refused to provide all through his life, the work that could come from his hand once he was dead". Em ibid., p. 114.

286 Idem. 
Responder à questão demandaria um exame detido do restante da trajetória do artista, o que certamente está fora do alcance desta dissertação. Limito-me a assinalar que a mesma conduta recriminatória de Seigel em relação ao "realismo figurativo" de Étant Donnés permeia, também, seu entendimento sobre a franca exibição do corpo feminino nessa obra. Para ele, a literalidade a que Duchamp submete a figura feminina é signo de um tratamento hostil e agressivo ao corpo da mulher, e, à primeira vista, poderia parecer, inclusive, o sintoma da relação difícil (e até mesmo misógina) que o artista mantinha com as mulheres. Se, no entanto, o diorama consiste - segundo sua hipótese - num contra-exemplo do Grande Vidro, a violência efetuada pela obra consistirá sobretudo em uma crueldade de Duchamp voltada a si mesmo(em sua forma feminina), e jamais em relação à feminilidade em si. ${ }^{287}$

Curioso raciocínio, que converte a franca exposição do corpo em um gesto de automutilação de Duchamp (e, nesse caso, também de Rrose Sélavy, como seu alter ego feminino). Mais curioso ainda se considerarmos que a literalidade de Étant Donnés - que Seigel tão veementemente afirma ser um "exemplo do que, para Duchamp, a arte não deveria ser", bem como signo de uma atitude violenta em relação ao corpo - é, precisamente, um dos aspectos mais ressaltados e mesmo enaltecidos por grande parte das autoras feministas que se dedicaram a analisar o diorama. Ao menos da década de 1990 em diante ${ }^{288}$.

Amelia Jones, em uma das mais conhecidas leituras feministas sobre a obra de Duchamp, não vê nada de problemático na despudorada exibição do corpo feminino em questão: trata-se da recusa da mulher a esconder sua "falta" ${ }^{289}$, de uma forma efetiva e eficaz de aterrorizar o espectador. Isto porque o manequim de Étant Donné, segundo Jones, não

287 Ao formulá-lo dessa maneira, o autor expõe uma concepção absolutamente anticarnal do desejo. Ele diz: "quando o desejo transfere-se do domínio da imaginação para o mundo terreno, converte-se em desengano, uma vez que contenta-se com a mera possessão física". Cabe sinalizar que Seigel reconhece que sua leitura opõe-se radicalmente à de Rosalind Krauss, comentada anteriormente nessa dissertação. Veja-se: Ibid., p. 112-3

288 Cabe sinalizar que uma das primeiras reações feministas a Étant Donnés ocorreu entre 1977 e 1978, quando a artista feminista Hanna Wilke produziu uma série de fotografias intituladas "I Object", em que expõe o próprio corpo nu em uma referência ao manequim exibido no diorama. Podemos mesmo interpretar o gesto de Wilke como algo ambíguo, que na mesma medida em que critica também reverencia a obra. A própria artista, em uma entrevista concedida em 1989, declarou: "History is a dialectical process. To honour Duchamp is to oppose him". Para uma discussão deste trabalho, cf. HORNE, Victoria. "Kate Davis: re-visioning art history after modernism and postmodernism. In: Feminist Review, No. 110 (2015), pp. 34-54.

289 JONES, Amelia, op. cit., pp. 201-202. Como se pode ver, a autora faz uso da psicanálise e da crítica à psicanálise para construir sua interpretação, recorrendo a Freud, Lacan e Irigaray. 
possui, efetivamente, uma vagina ou um ventre com lábios internos e externos à mostra: o que se exibe assemelha-se, antes, a uma fenda rasa e sem nada, a um órgão inquietantemente castrado ${ }^{290}$, que rejeita a penetração do olhar do espectador. A ausência de pelos pubianos do manequim só vem a reforçá-lo: "there is no avoiding this 'no thing to be seen"”291.

Mas é claro que a exibição ostensiva do corpo como elemento castrado só pode ser interpretada enquanto forma de resistência e como garantia de empoderamento em condições específicas. Isto é, ele deve estar integrado em um circuito que assevere que o corpo é exposto somente porquanto o olhar do espectador e suas determinações antes implícitas também o sejam. Para tanto, o dispositivo de Étant Donnés deve ser, como um todo, explícito e literal. E assim, de fato, ocorre: literal é sua alusão à perspectiva; explícita é a separação entre o observador e o corpo observado, entre o masculino e feminino; literal é o lugar do observador enquanto voyeur, bisbilhoteiro, peeping tom; explícita é a "falta" com que ele se depara ao sentir-se impelido a olhar e assim por diante.

Desse ponto de vista, exagero e literalidade são, enfim, as mais poderosas ferramentas de uma "máquina masculinista de representação perspectiva" que expõe "a contingência e o fracasso da oposição entre o masculino/observador e o feminino/observado, que estrutura a relação espectador-objeto na estética ocidental” ${ }^{292}$. Ao prescrever, demarcar e amplificar as distinções entre o feminino e o masculino, Étant Donnés não somente torna visível o papel da diferença sexual na formulação do olhar perspectivo, como também recusa-se a balizar essa distinção com pesos e medidas igualitários, evitando a falsa promessa de simetria sob a qual o patriarcado oculta seu poder. Trata-se, para Jones, de um gesto rumo à "crítica do que Irigaray denomina como 'oculocentrismo plurissecular' e masculinista" ${ }^{293}$, que reside no cerne da cultura ocidental.

290 Traduzimos por "inquietante" o que Jones denomina uncanny, termo extraído, como ela mesma reconhece, do conceito de unheimlich de Freud. Cf. JONES, op. cit., p. 202.

Não há correspondente exato em português, mas cumpre assinalar que o termo freudiano pode ser traduzido também por "estranho familiar".

291 Ibid., p. 201. Optamos, aqui, por manter a frase como no original, em inglês. Isso se deve ao fato de que a autora faz referência à crítica da psicanálise operada por Lucy Irigaray, lançando mão da distinção entre "no thing" e "nothing".

292 Ibid., p. 194. Extraído e traduzido livremente, do original: "Duchamp blatant ascription to the masculinist machine of perspectival representation - his perhaps too blunt enunciation of the viewer as masculine - in fact exposes the contingency and failure of the masculine/viewer and feminine/viewed opposition that structures the spectator-object relationship in Western aesthetics."

293 Ibid., p. 203. Traduzido livremente de: "a critique of what Irigaray terms the masculinist 'alge-old occulocentrism'". 
Passadas mais de três décadas desde que Jones sinalizara a importância da demarcada diferença sexual em Étant Donnés, não faltaram análises da obra que - quer fossem feministas, quer fossem de autoras e autores concernidos com a crítica feminista- atribuíram valor à literalidade e ao exagero de Étant Donnés, concebidos como um modo de expor e, com isso, negar o que antes estava implícito em constructos basilares da subjetividade e da sociedade contemporânea.

Sob determinada ótica, é verdade que essa posição é diametralmente oposta à de Seigel ou à dos que censuram veementemente a "obviedade" de Étant Donnes, como busquei demonstrar. Ainda assim, em algo, ao menos, ambas as posturas coincidem: tanto em um caso como no outro, a literalidade do diorama é vista como uma espécie de operação retórica por parte de Duchamp. Para Seigel, a literalidade era vista como uma operação retórica autobiográfica e prescritiva, como uma maneira de dizer, através da forma, em que não consistia o próprio trabalho.

No caso das abordagens de inclinação feminista, cumpre assinalar que a operação retórica (do objeto) em questão coincide exatamente com a própria estratégia do texto, isto é, com a "crítica" - não a crítica de arte, cujo surgimento institucional data do século XVIII com Diderot, evidentemente, mas a crítica em sentido amplo, hermenêutico ou analítico- concebida, em sua acepção mais generalizada, enquanto forma de revelar preceitos ideológicos que subsistem em formas dominantes do pensamento e do discurso. Neste caso, a obra de arte, ainda que se paute por estratégias distintas, é tratada como se compartilhasse objetivos semelhantes aos do texto crítico: a ambas cabe expor o que subjaz ao campo normativo da regra cultural.

Dalia Judowitz o expressa de maneira clara e concisa: para ela, Duchamp faz uma referência implícita à conhecida gravura de Dürer, Desenhista fazendo esboços de uma mulher em perspectiva (1532) (fig. 74), de modo a explicitar como corpo e olhar, ponto de vista e ponto de fuga são, na tradição perspectiva, constructos artificiais e formas históricas permeadas pela sexualidade ${ }^{294}$. A autora chega a afirmar, em nota, que interpreta o realismo exagerado de Étant Donnés como "reflexo do pós-modernismo de Duchamp, na medida em que ele torna visível a disposição retórica da mimese pictórica e escultórica enquanto modos de reprodução artística" ${ }^{295}$. Mais adiante, defenderá, inclusive,

294 Cf. JUDOVITZ, op. cit., pp. 210-211.

295 Ibid., p. 267. Traduzido livremente, do original: "I interpret the exaggerate realism [...] 
que o diomara de Duchamp "antecipa a crítica feminista do male gaze por desconstruir a estrutura, e portanto, também a ideologia da lógica masculina do olhar do espectador" ${ }^{296}$.

Interpretar Étant Donnés e, consequentemente, Duchamp como um pós-modernista ou feminista avant la lettre, como se seu diorama fosse o precursor da ultrajante reviravolta que estava por vir alguns anos depois, soa, certamente, exagerado ${ }^{297}$. No entanto, talvez seja impossível esquivar-se (como ressaltamos anteriormente no caso de Picasso e Sartre) da tentativa de compreendê-lo (e a todos) em meio a um mesmo processo histórico - no transcorrer do qual uma variada gama de discursos, correntes de pensamento e práticas (incluindo-se as feministas) pautaram a crítica generalizada do papel hegemônico da visão na sociedade ocidental ${ }^{298}$. Não se trata de "contextualizar" os trabalhos de Picasso Duchamp ou o pensamento de Sartre como se correspondessem a expressões idiossincráticas de um denominador comum, mas de buscar compreendê-los como elementos de propulsão e resistência a desafios e impasses de seu próprio tempo. Em todo caso, quer consideremos adequado, quer consideremos exagerado atribuir a Duchamp o estatuto de precursor da teoria do male gaze, nada exclui o fato de sua obra ter sido frequentemente recebida em chave positiva por artistas e autoras feministas. Ao contrário do que suporia o clichê, aos olhos de muitos. Larry Witham, ao fazer um balanço sobre a recepção de Étant Donnés, observa (sem citar nomes específicos) que, curiosamente, para a insurgente geração feminista dos anos I990, "a obsessão de Duchamp por mulheres peladas não era problemática se vista sob o prisma correto, isto é, sob o prisma da “ironia ${ }^{299}$ '. Um pouco adiante, encontra uma explicação semelhante

as a reflection of Duchamp's postmodernism, insofar as it makes visible the rhetorical display of pictorial and sculptural mimesis as modes of artistic reproduction"

296 Idem. Traduzido livremente, do original: "I will demonstrate that Duchamp anticipates the feminist critique of the male gale by desconstructing both the structures and, therefore, the ideology of male spectatorship."

297 Outra análise - menos brusca em suas comparações - entre voyeurismo, feminismo e Étant Donnés foi empreendida por: DAUBNER, Ernestine. Etant donnés: Rrose/Duchamp in a Mirror. ACAR: revue d'art canadienne / Canadian Art Review, Vol. 22, No. 1/2 (1995), pp. 87-96.

298 Esse processo histórico, conforme já sinalizei outras vezes, foi detidamente examinado e discutido por JAY, Martin, op. cit.

299 WITHAM, op. cit., p. 282. Traduzido livremente, do original: "For these feminists, moreover, Duchamp's obsession with naked women was not problematic when seen in the correct light, which was the 'ironic' light. They believed that Duchamp's artistic sex objects made a progressive commentary on 'voyeurism'". 
à que traçamos aqui: "Elas acreditavam que os objetos sexuais de Duchamp faziam um comentário progressista sobre o "voyeurismo'300”.

É claro que os motivos pelos quais a obra de Duchamp adquiriu grande aceitação por parte de críticas e autoras feministas vão muito além da relação de seu trabalho com o voyeurismo, no entanto. Devemos justamente a Amelia Jones um dos balanços mais completos sobre a questão. Ela examina de forma detida a maneira como Duchamp foi contraditoriamente interpretado, dos anos de 1960 aos anos de I990, como uma alternativa "feminizada" à estrutura masculina e heteronormativa do modernismo - seja por sua "ironia", por suas estratégias “anti-arte”, por sua invenção dos readymades ou por seu alter ego feminino Rrose Sélavy - passando a ocupar a posição paradoxal (mas nem por isso, como um todo, improcedente) de uma espécie de "pai disseminador de uma prática alternativa antimasculinista" ${ }^{301}$ e pós-modernista. Sua análise é complexa e elaborada, e se detém sobre uma ampla gama de material discursivo: Jones esmiúça escritos e declarações de críticos, historiadores, filósofos e artistas estadunidenses sobre o minimalismo, o neodadaísmo, os happenings, o Grupo Fluxus, a arte conceitual, a arte pop, entre outros. A análise desse vasto repertório permite a ela formular a hipótese de que a compreensão de Duchamp como um artista cujo trabalho é "anti-masculino" por excelência foi construída por uma multiplicidade de discursos sobre arte, por trás dos quais reside uma lógica de genealogia por oposição, que frequentemente mobiliza termos como "feminilidade", "feminismo" e "pós-modernismo" como se fossem inextricáveis ${ }^{302}$.

300 Idem.

301 Cf. JONES, op. cit, pp. 14.

302 Idem. Devo destacar que Jones tem uma visão crítica e bem consolidada em relação a esse modo de definição por oposição, que frequentemente vê nas atitudes "anti-arte" ou "anti-retinianas" ou nas invenções "readymades" um fundo "anti-masculinista" ou "femininista" por contingência, como se todos os termos compartilhassem em sua radicalidade uma afronta ao modernismo enquanto modo de determinação. É justamente por isso que ela propõe uma leitura de Étant Donnés na qual valoriza a literalidade da obra como uma estratégia de explicitar a diferença sexual, ao invés de ressaltar o caráter insubordinado e irreverente da produção de Duchamp. Sua análise data de 1994, e é curioso que, imediatamente em seguida, muitas serão as leituras da obra que, alinhando-se com Jones, defenderão o diorama por características semelhantes, como uma espécie de comentário sobre o voyeurismo, conforme define Witham. Em que medida essas interpretações de Étant Donnés coincidem ou se diferenciam dos discursos examinados e problematizados por Jones e como isso relaciona-se com as mudanças de parâmetros para a análise feminista na década de 1990 é uma questão que mereceria ser investigada. Para isso, não obstante, seria necessário se aprofundar no debate feminista no campo da arte e da psicanálise nesse período, o que excede o alcance dessa dissertação. 
A genealogia por antagonismo a que Jones se refere não foi construída, em estágio germinal, por uma simples oposição à "estrutura masculina e heteronormativa do modernismo", mas por oposição à estrutura masculina e heteronormativa do modernismo tal como formulado por Clement Greenberg ${ }^{303}$. Isto é, no cerne dessa oposição, residia uma recusa aos parâmetros que sustentavam uma posição particular (e que, para muitos, parecia hegemônica por então) de defesa do expressionismo abstrato. E um desses parâmetros era, como se sabe, a obra de Picasso ${ }^{304}$.

Não o Picasso de Las Meninas, evidentemente. Este, segundo o próprio Greenberg ${ }^{305}$, havia sucumbido, desde 1927 ou I928, a uma crise da qual jamais se recuperara e que, pelo contrário, só augurava aprofundar-se cada vez mais ${ }^{306}$. O veredito, em realidade, foi sentenciado em outubro de 1957 (poucos meses antes da produção da série) em um breve e contundente ensaio crítico sobre Picasso na revista Arts Magazine. Nele, Greenberg afirmava em tom consternado: "Sob todas as mudanças de tema e maneira, sente-se o desejo de um virtuose ambicioso que busca mais a felicidade da invenção do que soluções

303 Não que Greenberg tenha chegado a formular, efetivamente, uma teoria sobre arte moderna. De acordo com Rodrigo Naves, "seus textos mais abrangentes de certa maneira sintetizam e sistematizam formulações que já se encontravam em vários outros autores, em geral artistas". Cf. NAVES, Rodrigo. "As duas vidas de Clement Greenberg", em Greenberg, Arte e Cultura: Ensaios Críticos, São Paulo: Cosac Naify, p. 11. Quando Amelia Jones se refere a uma noção masculinista de modernismo tal como Greenberg o concebe, não alude à teoria de Greenberg sobre o modernismo stricto sensu, mas à forma como determinados artistas e críticos, a partir dos anos de 1960, amiúde atribuíam a Greenberg uma série de predicados disseminados no campo da arte, definindo-se por oposição ao pensamento que ele veio a representar.

304 É conhecido o papel do cubismo na genealogia greenberguiana da arte moderna. Considere-se, por exemplo, a avaliação do crítico em 1950: a arte de Pollock, De Kooning e Gorky "representa, em minha opinião, o primeiro esforço genuíno e irresistível para impor a ordem cubista [...] à experiência do mundo pós-cubista, pós-1930". Em: GREENBERG, op. cit., p. 17.

305 Cf. GREENBERG, Clement. "Picasso aos 75 anos", em Arte e Cultura: Ensaios Críticos, São Paulo: Cosac Naify, pp. 81-91.

306 De fato, o diagnóstico de uma figura tão relevante à esfera pública como a de Greenberg indica que por traz da rígida distinção entre um Duchamp precursor do pós-modernismo e um Picasso modernista por excelência, haveria um grau maior de complexidade amiúde obliterado ou ignorado pelos rumos do debate, mas perceptível aos olhos de artistas e críticos poucos anos depois. Tenhamos em vista, por exemplo, o que o artista Larry Rivers escreve em um balanço sobre a primeira grande retrospectiva póstuma dedicada à obra de Picasso no Museu de Arte de Nova York: "What do we now think of Clement Greenberg, as the most venerable among a host of others, convinced back as far as '50s (and perhaps still) that after 1921, Picasso was finished? What did they mean? Do they still feel this way?". Cf. "Picasso, a Symposium", in: Art in America, Picasso Special Issue, december 1980, p. 12. 

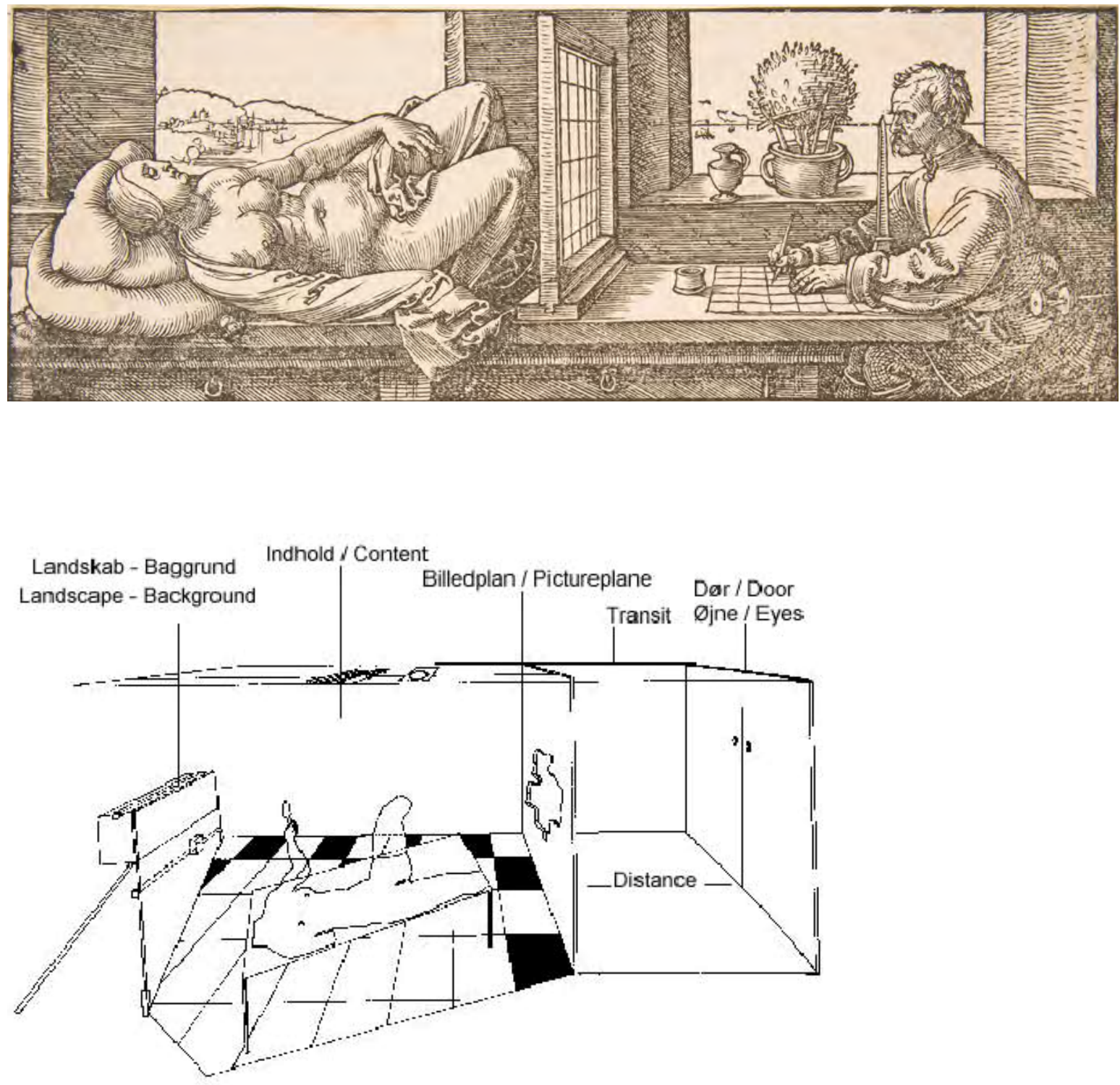

74 Albrecht Dürer

Desenhista fazendo esboços de uma

mulher em perspectiva

Xilogravura do tratado sobre perspectiva

Unterweisung der Messung

1525

75 Esquema perspectivo de Étant Donnés, obra de Marcel Duchamp 
inspiradas. Persiste uma espécie de excitação, mas a plenitude e a exuberância de antes se foram; o que está em jogo não é mais a substância da grande arte, só sua aparência" ${ }^{307}$.

Esse era Picasso, o Picasso de Las Meninas, um artista de setenta e cinco anos que não fazia questão de esconder seu desapreço pela arte para a qual Greenberg advogava. Esse era Picasso em 1957, um artista que - lembremos do episódio mencionado na introdução - "sente-se angustiado com a obra de muitos expressionistas abstratos, e uma vez agarrou um mata borrão manchado de tinta, arremessou-o num visitante e gritou: ‘Jackson Pollock!'”308.

Esse era Picasso, cuja obra foi tomada por gerações posteriores - seja enquanto modelo ou contramodelo, enquanto referência por semelhança ou antítese, e mesmo de outras formas - como parâmetro para definição do que é moderno, pós-moderno, feminino ou masculino em artes, mas cujo trabalho nunca foi monolítico ou regular. E isso justo Greenberg, à sua maneira, havia constatado. Para ele, como para muitos outros naquele momento, a produção atual de Picasso parecia - diferentemente do cubismo, ou mesmo de sua produção dos anos de 1920 a 1930 - fora de lugar, à revelia da fama e prestígio da qual inegavelmente desfrutava.

Mas mesmo esse Picasso talvez estivesse produzindo algo menos isolado do que, por então, faria supor o debate.

Em todo caso, poucas coisas são mais ineficazes que exigir de um debate que paute o que não estava no horizonte: a Greenberg, o que lhe concernia era a experiência estética que a pintura era capaz de proporcionar e àqueles que o rebatiam, o desafio era fazer ebulir tudo aquilo que uma concepção rigorosa da obra de arte ameaçava atrofiar.

Foi somente nas décadas seguintes que a discussão sobre as relações entre olhar, voyeurismo e sexualidade se instaurou definitivamente no campo das artes visuais - em parte permeada por influxos de estudos em filosofia e cinema, em parte devido à renovação imposta pelo feminismo em ambos esses segmentos. Étant Donnés, de Duchamp, é prova viva de como a interpretação de um trabalho de arte pôde transmutar-se à luz desse debate revigorado. Quer estejamos ou não de acordo com o que foi dito ou valorizado da obra, é inegável que as discussões enriquecem as formas como a vemos e a interpretamos.

307 GREENBERG, op cit.., p. 83.

308 Ibid., 91. 
Quando se trata desse Picasso, isto é, do Picasso de Las Meninas, o caso é diferente. É capaz que questões inerentes à recepção de seu trabalho desde o final da década de I950 em diante tenham mesmo obliterado certos aspectos da série que, não obstante os sucessivos empenhos de desconstrução no campo disciplinar da história da arte, permanecem a ser discutidos ${ }^{309}$. Volto a dizer: o modo voyeurista de mediaçao entre o observador e as figuras na pintura, a remissão do espectador a um olhar flagrante, as alusões à perspectiva e à tradição enquanto formas concupiscentes e marcadas pela diferença sexual - isto é, os componentes elementares que parte da literatura ressaltou em Étant Donnés, sobretudo desde os anos de 1990 - todos eles se fazem sentir em Las Meninas, embora nem sempre tenham sido examinados com a merecida atenção.

Fazem-se sentir de modo sugestivo, é claro - jamais de forma literal, como em Étant Donnés. Essa é uma diferença fundamental entre os trabalhos, mas não necessariamente é indicativa de uma oposição em sentido estrito. Isso porque fazer-se sentir enquanto sugestão é bastante diferente de subsistir enquanto premissa. Trata-se, ao fim e ao cabo, de insinuar, o que não exatamente é o contrário de tornar literal.

Esse raciocínio só é efetivo, evidentemente, se adotarmos o princípio de que tornar literal é explicitar aquilo que, de outra maneira, permanecia em uma condição latente. $\mathrm{Ou}$, dito de uma forma mais clara, se considerarmos, como grande parte das abordagens de Étant Donnés de vertente feminista, que a literalidade pode ser interpretada como uma estratégia retórica para desvelar os preceitos ideológicos enraizados em formas dominantes de expressão.

Mas se a obra de Duchamp deflagra os pressupostos ideológicos que subjazem à visualidade na cultura figurativa ocidental, não é como se Picasso, por oposição, simplesmente os encarnasse e os mantivesse solapados sob o revestimento de suas pinturas. Tanto é que nem Las Meninas e nem os demais trabalhos do artista ocultam estar enraizados em postulados , por exemplo, de diferença sexual ou assimetria de gênero ${ }^{310}$.

309 O assunto foi discutido por: SALZSTEIN, Sônia. A presença enviesada da obra de Picasso no debate da arte dos anos 1980 à atualidade: Algumas questões teóricas. In: XXXI Colóquio do Comitê Brasileiro de História da Arte. Museu Nacional de Belas Artes, Rio de Janeiro, 2010.

310 Isso parece ter incomodado inclusive um crítico do calibre de Donald Kuspit, que após ver a retrospectiva de Picasso no Museu de Arte de Nova York em 1980, escreve: "His [Picasso's] jealousy of Velázquez - Las Meninas reduced to another nasty game of male/female, artist/model relationship - is shown by his rape of Velázquez's style, his total dismanteling, reduction to a rubble of forms, of Velázquez's vision". Cf. . KUSPIT, Donald B. "Picasso, a Symposium", in: Art in America, 
Pelo contrário, eles mobilizam seus componentes hierárquicos como radicais livres em um jogo à deriva, solicitando-os sem trégua para tirar deliberado partido de sua existência, sem querer escondê-los e sem necessariamente acabar por omiti-los involuntariamente - e, no caso da série, sem tampouco expô-los, mas insinuando-os através da própria forma das pinturas e do movimento entre elas.

Repito: neste caso em específico. Pois se os trabalhos de Picasso nunca foram, de fato, literais - isto é, independente do que está figurado, suas pinturas serão sempre pinturas, suas esculturas seguirão sendo esculturas e sua produção gráfica será sempre gravura - em matéria de tornar explícito, de escancarar e de exibir sem pudor, sua obra não deve absolutamente nada à de Duchamp.

Isso é perfeitamente visível na produção que se seguiu à realização de Las Meninas e que se estendeu persistente e quase ininterruptamente até I973, quando a morte fez cessar definitivamente a atividade artística do nonagenário Picasso. Nas obras realizadas durante esse período, aquilo que antes residia enquanto interesse - e que, em Las Meninas, estava apenas sugerido - torna-se objeto de uma manifesta e compulsiva obstinação. Refiro-me sobretudo às séries de gravura realizadas entre 1968 e 1972, mais conhecidas como Suite 347 e Suite 156. Elas compõem grande parte da numerosa e variada obra gráfica de Picasso nos últimos anos de sua vida, que faz do repertório da história da arte um catálogo inesgotável, cujo conteúdo pode ser embaralhado livre de qualquer constrangimento a imagens de franco apelo sexual, que, no limite, chegam a flertar com os clichês da pornografia vulgar, nas quais vaginas abertas e membros masculinos eretos e penetrantes são figurados sem escrúpulo3ir.

Surpreende a tenacidade e o engajamento com que Picasso nessas gravuras reprisa, parodia e expõe desinibidas tramas de voyeurismo, de exibição do corpo e do ato sexual, infundindo-as com todo tipo de material extraído da tradição da pintura. Surpreende também a forma com que muitas delas, em sua franca exposição, estranhamente remetem à situação em que o espectador se encontra em Étant Donnés. São muitas as estampas em que a figura feminina converte-se em um nu reclinado, de pernas escancaradas

Picasso Special Issue, december 1980, p. 20.

311 Leo Steinberg, em seu ensaio sobre As Mulheres Argelinas de Picasso, defende que Picasso, como nenhum outro artista, apodera-se "do poder expressivo e estrutural do clichê". STEINBERG, Leo. Outros critérios: confronto com a arte do século XX. São Paulo: Cosac Naify, 2008, pp. 163-288. 
e vagina à mostra, cuja pose curiosamente faz recordar o manequim em Étant Donnés ${ }^{312}$ (ainda que Picasso provavelmente nem sequer o vira). Muitas também são as gravuras em que essa mesma figura feminina direciona-se simultaneamente ao espectador e a um personagem masculino postado nos limites da própria gravura, como se, com um único movimento, pudesse endereçar seu órgão sexual ao observador no interior do campo visual, um voyeur, e ao espectador fora da imagem - igualmente voyeur.

Surpreende, ainda, o fato de que se retomarmos a trajetória que une Las Meninas a essas gravuras, veremos como todos os trabalhos fazem parte de um único percurso, no qual aquilo que estava presente na série de 1957 é constantemente repaginado e submetido a um incansável processo de variação, repetição e intensificação.

E no decorrer desse processo, tudo se torna cada vez mais explícito.

\section{Picasso em suas últimas décadas de vida}

Há uma dentre as tantas e tantas gravuras de Picasso (fig. 76) - uma água-tinta datada de 1959, cujo paradeiro é por nós desconhecido - que nos permite observar como o processo ao qual me refiro vem, pouco a pouco, a consolidar-se nas últimas décadas de vida do artista.

Refiro-me a uma estampa em tons escuros, construída por camadas sobrepostas de manchas fluidas que envolvem o espectador em uma atmosfera diáfana de tons fuliginososos e betuminosos. Há, nessa gravura, um forte contraste entre a turva escuridão que contagia o fundo e pontuais áreas iluminadas, que em geral coincidem com o corpo das figuras femininas representadas. Não obstante, nada no ambiente figurado é sombrio, nada é tenebroso, nada é lúgubre: pelo contrário, a vaporosidade de matizes de castanho queimado evoca uma sensação morosa, de vigorosa languidez. Estamos em um bordel.

Mas espere. Há algo de familiar nesse bordel. Meu palpite é de aqueles afeitos à obra de Picasso de imediato recordarão uma ou outra das variações realizadas alguns anos

312 Cabe destacar que a exposição "Picasso Érotique" - realizada em Paris, Montreal e Barcelona e curada por Dominique Dupuis-Labbe e Jean Clair, em 2001 - trabalhou, de modo sugestivo, a relação entre a figuração escancarada do corpo na obra de Picasso e Étant Donnés. De acordo com uma resenha sobre a mostra, de autoria de Robert Silberman, foram inseridos nas paredes do espaço expositivo uma série de buracos para os olhos, cuja referência imediata era o diorama de Duchamp. Cf. SILBERMAN, Robert. "Picasso Érotique: Paris, Montreal, Barcelone", in The Burlington Magazine, Vol. 143, No. 1184 (Nov., 2001), p. 716. 
antes a partir de Mullheres Argelinas, de Delacroix. Quem sabe venha à tona a variação M (fig. 77) , uma tela realizada a partir de tons quentes e grisalhos e de pinceladas etéreas, de amplitude atmosférica. Embora na gravura mais recente, Picasso não estivesse preocupado, como antes, com a severa tarefa de compor aspectos de simultaneidade em uma mesma forma convergente ${ }^{313}$.

É também provável que essa gravura faça recordar diretamente a pintura de Delacroix. Quiçá não só a obra-prima do Louvre, mas também uma segunda versão da pintura, hoje no Museu Fabre, em Montpelier (fig. 78) - aquela mais classicizada, nas palavras de Leo Steinberg ${ }^{314}$, executada posteriormente em uma tela de menores dimensões -, uma pintura em que um feixe de luz cálida e contrastada recai sobre as figuras femininas quiescentes que fumam e descansam vagarosamente, sem por isso estarem alheias à coqueteria sensual.

Pode ser, ainda, que o leitor recorde as aguadas de Delacroix (fig. 79), aquelas realizadas a partir dos célebres caprichos de Goya - estudos de pose, luz, mancha e contraste, que gozam da mesma ambiência circundante, simultaneamente turva, rarefeita e envolvente da gravura de Picasso.

E não param por aí as referências capazes de situar a gravura em meio a um universo familiar. Reparemos na disposição das figuras no aposento, e também na silhueta ao fundo, que irrompe da abertura de uma porta luminosa. Como não recordar Las Meninas, depois de tanto discutirmos a proeminência da irrupção de José Nieto Velázquez?

Cumpre reiterar, contudo: estamos, doravante, em um bordel.

É como se em algum momento, para Picasso, o vasto repertório, a linguagem, os estilos, maneiras e os motivos presentes na arte de todos esses "grandes mestres" da pintura ocidental - de Velázquez a Goya, de Goya a Delacroix - estivessem imiscuídos em um repositório de referências de livre disponibilidade, mobilizadas em torno de uma única imagem: uma cena de bordel.

E não qualquer cena de bordel.

Talvez seja conveniente, antes de mais nada, recorrer a uma explicação sumária sobre a técnica utilizada por Picasso nessa gravura. Ela consiste em uma técnica conhecida

313 STEINBERG, Mulheres Argelinas de Picasso em Aberto, em Outros Critérios, op cit., pp. 194-196.

314 ibid., p. 167. 
como "água-tinta ao açúcar", frequentemente utilizada para atingir, na gravura, manchas de uma variada gama de tons. Através dela, é possível lograr efeitos de transparência, fluidez e espontaneidade característicos antes do desenho e da pintura que da gravura e, mais especificamente, do desenho a aguada, a meio caminho entre as duas linguagens.

Essa não é a única maneira de alcançar fluidez e espontaneidade a partir de uma matriz gráfica. Dentre os tantos procedimentos característicos do universo da gravura, há uma técnica que, embora bastante diferente daquela utilizada por Picasso, pode surtir efeitos muito semelhantes aos que nos referimos. Trata-se de um procedimento gráfico não-ortodoxo do qual Edgar Degas tirou partido para produção de sua (hoje) célebre série de estampas de bordel: a monotipia.

Não é de estranhar que os pontos de convergência entre as monotipias de bordel de Degas e a gravura de Picasso sejam muitos. Para além dos efeitos de forte contraste entre luz e sombra gerados por justaposição de manchas e massas escuras livremente articuladas, há, ainda, uma afinidade entre a maneira com que as figuras femininas se apresentam. Seus corpos, em geral, são os pontos de maior luminosidade em um ambiente às escuras, inundado por uma nebulosa iluminação artificial. Essas figuras compartilham traços fisionômicos e adereços particulares: em ambos os casos, o que vemos são prostitutas de pernas voluptuosas vestidas com meias escuras até os joelhos, mulheres de tronco sólido e robustas ancas. Elas ostentam o peso convalescente de sua carne, gravitando rumo à descontração informal e lasciva de um momento de descanso, intimidade e absoluta desfadiga.

Em um número considerável das cerca de cinquenta monotipias de Degas que hoje conhecemos ${ }^{315}$ vemos não só essas tantas prostitutas em seus momentos de higiene pessoal e de descontração, mas também a figura do cliente - um burguês em trajes negros, de cartola e sobretudo - observando reticente a cena que se descortina perante seus olhos. A figura do cliente retraído despertará vivaz interesse em Picasso, conforme discutiremos mais adiante. Ela está presente em três das nove monotipias de Degas que Picasso possuía em sua coleção e em uma delas aparece de maneira bastante curiosa (fig. 80). Ele convertese em uma silhueta furtiva da qual vemos apenas parte indefinida: o nariz, a ponta da cartola e um fragmento de pernas em movimento. Trata-se de um vulto acantoado atrás

315 Segundo o marchand Ambroise Vollard, estima-se que existiam outras setenta monotipias que foram descartadas pelo irmão de Degas após a morte do artista, provavelmente por terem sido consideradas indecentes. Cf. BERNHEIMER, Charles. "Degas, Voyeurism and Ideology 
da porta ou, em outros termos, de um bisbilhoteiro voyeur que não só observa prostitutas em seu átimo de intimidade e recesso, mas as observa às escondidas.

Essa figura, como notou Elizabeth Cowling, faz lembrar a silhueta que subitamente irrompe pela porta ao fundo na gravura de $1959^{316}$. Ela também evoca, como Cowling mesmo observa, a sombra de José Nieto em Las Meninas - que tinha tanto protagonismo na série produzida dois anos antes ${ }^{317}$.

Tão singela e insólita convergência não é prova de nada, é claro, mas nos leva a pensar o quanto olhar, voyeurismo e erotismo estavam, de fato, presentes (de forma latente) em Las Meninas, por mais distantes que esses termos parecessem da pintura de Velázquez em um primeiro momento. Isso se considerarmos que conforme se passaram os anos voyeurismo e sexualidade vieram a ser, para Picasso, absolutamente inseparáveis do repertório infinito da história da arte, que, por sua vez, era nada menos que o material primeiro para sua produção naqueles anos.

Não que tudo isso já não estivesse presente anteriormente na obra de Picasso. Estabelecer uma data ou um momento que precise quando, exatamente, as paródias sexuais e voyeuristas entram em cena na produção do artista é praticamente impossível ${ }^{318}$. $\mathrm{O}$ processo de apropriar-se das mais diversas referências da história da arte ocorre desde que Picasso era bastante jovem, estendendo-se ao longo de toda sua trajetória - e quase sempre esteve aliado a uma dimensão erótica que o artista nunca fez questão de esconder. Poderíamos retroceder à primeira década do século XX e veríamos que, já nessa época, Picasso voltou-se, por exemplo, à Olympia de Manet (e às suas referências remotas a Ticiano) ou a pinturas de Gauguin para produzir versões próprias impregnadas de conteúdo sexual ${ }^{319}$.

316 COWLING, 2010, op. cit., p. 233.

317 idem.

318 A literatura sobre o processo de apropriação na obra de Picasso é vasta e expressa diferentes pontos de vista. Elenco: KRAUSS, "Picasso/Pastiche", in Os Papéis de Picasso, op. cit., p, 97-202; ANGLIN-Buhard, Timothy, "Picasso and Appropriation", in The Art Bulletin 72, n. 3, 1991, pp. 479-894; WOLLHEIN, Richard. "Pintura, Textualidade e Apropriações", in A Pintura como modelo, São Paulo: Cosac e Naify, 1992, pp. 187-248.

319 Tanto a paródia à Olympia como uma paródia de O Espírito da Morte assistindo (Manao Tupapau), de Gaguin, foram realizadas entre os anos de 1902-3. É interessante que nos últimos anos de vida, Picasso retorna às pinturas de Manet e Gauguin mediadas por suas próprias versões juvenis. 

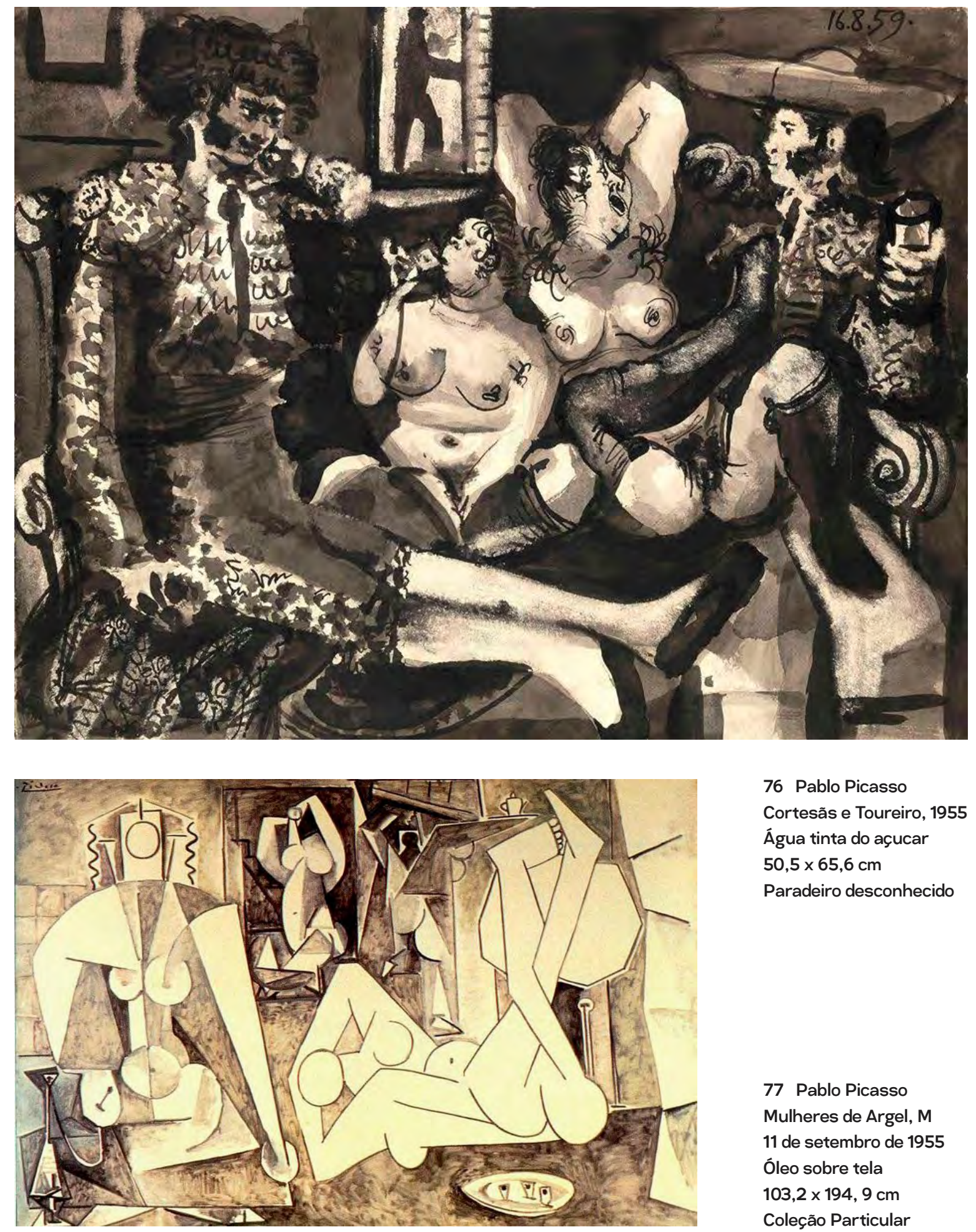

76 Pablo Picasso

Cortesãs e Toureiro, 1955

Água tinta do açucar $50,5 \times 65,6 \mathrm{~cm}$

Paradeiro desconhecido

77 Pablo Picasso

Mulheres de Argel, M

11 de setembro de 1955

Óleo sobre tela

103, 2 x 194, $9 \mathrm{~cm}$

Coleção Particular 

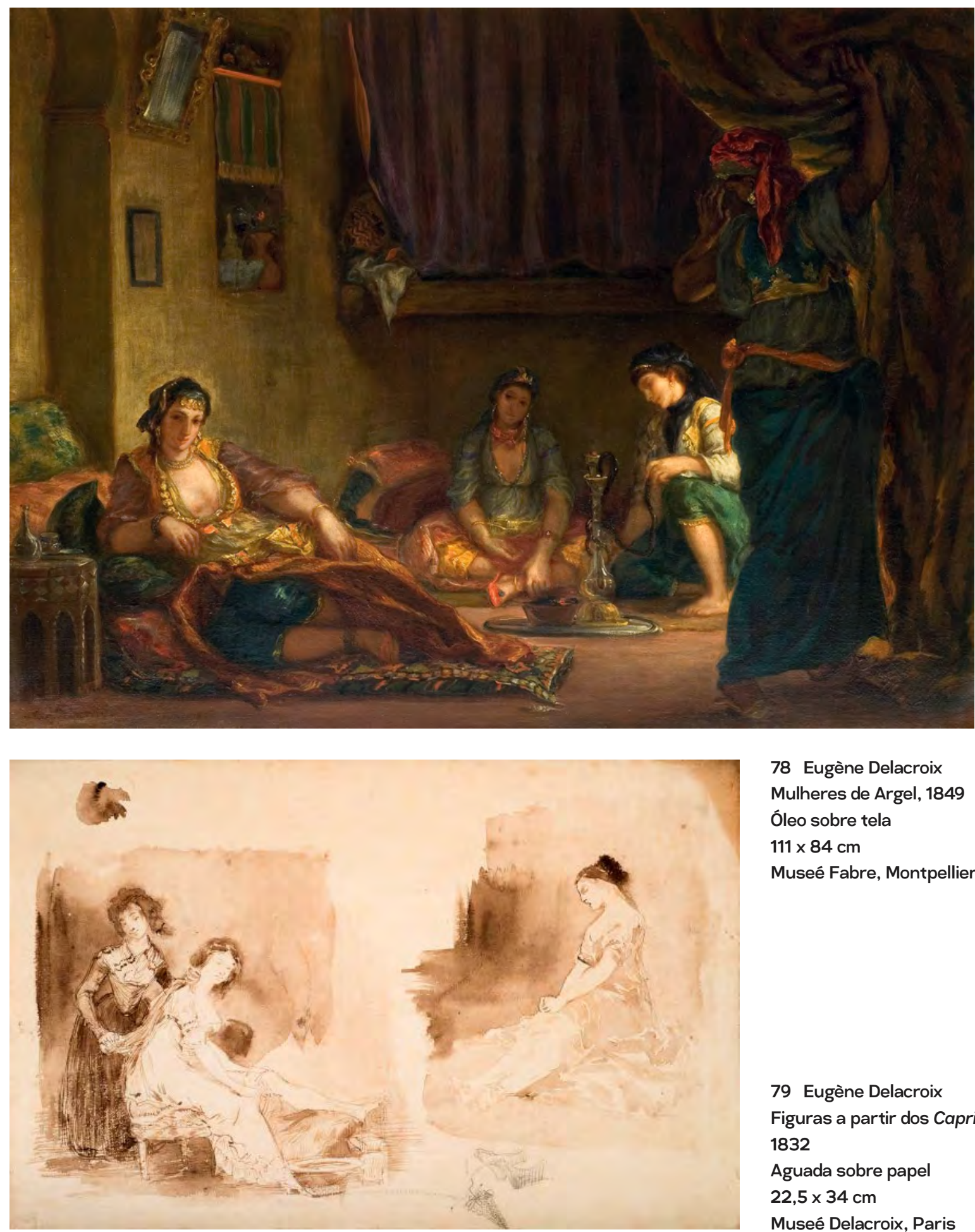

78 Eugène Delacroix

Mulheres de Argel, 1849

óleo sobre tela

$111 \times 84 \mathrm{~cm}$

Museé Fabre, Montpellier

79 Eugène Delacroix

Figuras a partir dos Caprichos de Goya, 1832

Aguada sobre papel

$22,5 \times 34 \mathrm{~cm}$

Museé Delacroix, Paris 




80 Edgar Degas

O repouso, 1879

Monotipia

$16,4 \times 21,6 \mathrm{~cm}$

Museé Picasso, Paris

O fato, não obstante, é que a partir do final da década de 1950 - isto é, a partir do período em que ocorre o ciclo mais intenso de variações de obras primas dos "grandes mestres" da arte ocidental - essas paródias entram em cena de forma mais explícita e contundente, até que paulatinamente passam a ocupar quase toda a produção dos últimos anos da vida de Picasso, que, aliás, jamais sucumbiu à desaceleração que a passagem do tempo poderia fazer crer.

Posto de forma mais clara, o que sugiro é que o período dos "grandes mestres" na obra de Picasso, como se convencionou denominá-lo (1964-1972) 320, é inseparável da produção madura do artista. Ou que muitas das questões que Picasso vinha explorando durante esse período retornaram, posteriormente, com força total e de modo incontornável. A maneira como Picasso articula, no interior de seus trabalhos, uma rede complexa de referências que inclui as monotipias de bordel de Degas - insistindo em repaginá -las no interior de tramas explícitas de voyeurismo e exibicionismo que se imiscuem

320 Me guio, aqui, pela periodização proposta por GALASSI em "Picasso's variarions on the masters", op. cit. Essa periodização é bastante comum: o período de variações dos "antigos mestres" iniciaria com as variações de Femmes d'Alger, em 1954, e termina com as últimas variações de Déjeneur sur l'herbe, de Manet, em 1962. Não obstante, é recorrente, também, em abordagens consolidadas, que se reúna esse período a partir de fases da vida pessoal de Picasso, sob a rubrica "La Californie", que indica a residência de Picasso nesse período. Cf., por exemplo, DAIX, Pierre. La vie de peintre de Pablo Picasso, Paris: Éditions du seuil, 1977; PENROSE, Roland. Picasso, op cit. 
no próprio repertório da tradição e utilizando-se de um vocabulário a um só tempo franco, ácido e paródico - conforme buscarei argumentar, só vem a confirmá-lo. Isso ocorrerá contundentemente nas séries de gravura conhecidas por Suite 347 e Suite 156, nas quais Degas é muitas vezes figurado como um cliente em bordeis bastante semelhantes àqueles de suas próprias monotipias.

Pareceria evidente supor continuidade e intensificação como traços marcantes de uma trajetória artística como a de Picasso, não fosse a dificuldade que a organização, a periodização, a classificação e a catalogação dessa obra - extensa e longeva, atravessando sete décadas do século XX - frequentemente nos impõem. Retomo a questão brevemente: Picasso, como se sabe, desde I928, começou a datar diligentemente cada um de seus trabalhos. Alguns anos depois, confiou a Christian Zervos a complicada tarefa de produzir um extenso catálogo de sua obra até então, organizado a partir de critérios quase sempre cronológicos. A ideia de que seu trabalho seria contemplado como um processo realizado dia após dia ou como uma espécie de diário de uma personalidade dramática lhe agradava fortemente. Tenhamos em vista, por exemplo, o que Picasso disse a Brassai, certa vez:

Por que pensa que dato tudo o que faço? É que não basta conhecer as obras de um artista. É preciso saber quando ele as fez, por que, de que modo, em que circunstância. Certamente haverá um dia uma ciência, que talvez chame a "ciência do homem", que buscará penetrar mais fundo o homem através do homem criador... Penso seguidamente nessa ciência e quero deixar à posteridade uma documentação tão completa quanto possível... Eis por que dato tudo que faço... ${ }^{321}$

Se considerarmos, como Christopher Green, que ao organizar e apresentar seu próprio trabalho dessa forma "Picasso não somente nos deixou uma obra de tamanho e escopo excessivos, mas também fez muito para determinar como respondemos a ela ${ }^{322 ",}$ veremos que tal atitude é ao menos parcialmente responsável por consequências particulares na recepção de sua obra - se não como estímulo, ao menos enquanto selo de legitimidade.

321

BRASSAï, Conversas com Picasso, São Paulo: Cosac Naify, 2000, p. 135.

322 GREEN, Christopher, "Different Picasso's", em Picaso: Architecture and Vertigo, op. cit., p. 3. Cabe observar que a atitude de Picasso que descrevo é analisada de forma detida por Green ao longo de todo o capítulo, cf. pp. 3-18. 
Uma dessas consequências e provavelmente a mais significativa, segundo Green ${ }^{323}$, concerne tanto à periodização quanto às vias pelas quais amiúde se compreende a obra de Picasso. Pois sabemos que muitos dentre os mais relevantes estudiosos do legado do artista (incluindo-se William Rubin e John Richardson) buscaram compreender sua produção em fases que se desenvolvem em simbiose com uma série de acontecimentos biográficos, eles mesmos associados com uma ou outra mudança ou inovação formal, com o emprego de determinado estilo etc. Linhas preciosas já foram escritas sobre o assunto $^{324}$, de forma que me limitarei a apontar apenas o que está intimamente vinculado ao nosso entendimento de Las Meninas e das séries de gravuras realizadas nos últimos anos de vida de Picasso, as Suite 347 e Suite 156.

Segmentar a obra de Picasso em grandes blocos intimamente relacionados a uma dimensão privada da vida do artista faz com que vejamos a produção de seus últimos anos de forma particular. Isso porque de maneira mais ou menos concomitante ao ciclo mais intenso de variações de obras de "grandes mestres", Picasso realizou, ainda, recorrentes incursões na história da arte de viés "polititizado", frequentemente agrupadas por seu caráter "humanista" e sua aversão à guerra e ao totalitarismo enquanto mecanismos de terror - de Guernica (1939) ao Rapto das Sabinas (1963), passando por A Ossada (1944-5), Massacre da Coréia (I95I), Guerra e Paz (1953) e até mesmo A Queda de Ícarus (1958). Essa empreitada, que ocorre simultaneamente ao engajamento de Picasso (seja ele efetivo ou simbólico) com o Partido Comunista Francês ${ }^{325}$, é muitas vezes considerada como o último respiro de Picasso antes de embarcar em solidão nas verdadeiras entranhas da idade madura. Gert Schiff, um dos que mais detidamente se debruçou na produção de Picasso destes anos, após comentar brevemente o viés humanista de cenas de abdução e estupro na pintura Rapto das Sabinas (I963), o coloca de maneira clara:

\section{3 ibid., p. 8-9.}

324 Além de Green, cabe destacar: KRAUSS, Rosalind."In the name of Picasso", October, Vol. 16, Art World Follies (Spring, 1981), pp. 5-22; KRAUSS, Rosalind. "Romances Baratos", in Os Papéis de Picasso, trad. Cristina Cupertino. São Paulo: Iluminuras, 2001, pp. 205-223. Também devo sublinhar que a discussão acerca da unidade da arte de Picasso é feita em SCHAPIRO, Meyer. A Unidade da Arte de Picasso, trad. Ana Luiza Dantas Borges, São Paulo: Cosac Naify, 2002.

325 A esse respeito, veja-se UTLEY, Gertje. Picasso: the Communist Years, New Haven: Yale University Press, 2000. 
Cenas de estupro e de rapto ocorrem novamente, seis anos mais tarde, em muitas gravuras da Suíte 347. Esses episódios obscenos, entretanto, não conservam nada do enfurecido humanismo da série anti-guerra. Eles pertencem à esfera da comédia picaresca, ao vasto panorama das loucuras humanas do século XVII, concebidas exclusivamente para o deleite privado de Picasso. Ele disse, certa vez: 'Passei horas a fio observando minhas criaturas enquanto desenhava, pensando nas loucuras tramadas por elas. Essa, basicamente, é a minha maneira de escrever ficção'.326

O que há de paradigmático no apontamento de Schiff não é tanto a periodização da obra em si, mas a periodização por contraste ${ }^{327}$, que ordena o processo criativo de Picasso à semelhança de uma grande batalha cujo desenvolvimento se dá através de uma dialética impulsionada por contradições internas. "A mudança na atitude de Picasso", escreve Schiff, "aconteceu um dia após terminar as pinturas anti-guerra" ${ }^{22}$. Enquanto, por um lado, as obras "politizadas" diziam respeito a uma visão humanística relativa à esfera pública do pensamento, a produção posterior a elas seria como o seguinte capítulo de uma novela em vida, cujo desfecho é o "retiro rumo a um mundo de fantasias privadas" 329 que a idade é capaz de reavivar. Essa abordagem que vê na produção madura de Picasso uma espécie de júbilo senil em um universo particular de ficção, memórias e afetos é bastante recorrente quando o assunto são as séries de gravuras dos anos 1960 e 1970.

326 SCHIFF, Gert. "Picasso's Old Age: 1963-1973", in Art Journal, Vol. 46, No. 2, Old-Age Style (Summer, 1987), p. 123. Traduzido livremente, do original: "Rape and abduction occur again, six years later, in a great many etchings of Suite 347. These bawdy scenes, however, retain nothing of the enraged humanismo $f$ the antiwar series. They belong to the sphere of picaresque comedy, to a vast seventeenth-century panorama of human follies, conceived solely for Picasso's private delectation. He once said, 'I spent hour after hour while I draw, observing my creatures and thinking the mad things they are up to, basically, it's my way of writing fiction'.

The change in Picasso's attitude came the day after he finished the antiwar paintings".

327 É claro que esta é apenas uma forma particular de periodizar o trabalho. De qualquer forma, é recorrente nos escritos sobre a obra madura de Picasso que se tente achar um fato biográfico que impulsiona esse voraz ímpeto pela produção de gravuras. Beryl Barr-Sharrar, por exemplo, atentará para o fato de que Picasso começa a série no dia seguinte à morte de seu amigo Jaimes Sabartès. Cf. BARR-SHARRAR, Beryl. "Some Aspects of Early Autobiographical Imagery in Picasso's Suite 347", in: The Art Bulletin, Vol. 54, No. 4 (Dec., 1972), pp. 516-533.

328 Idem

329 Idem, retirado e traduzido livremente, do original: "Caracteristically, his withdraw into a world of private fantasy began with the investigation of the nature of artistic activity." 
Se nos propuséssemos a percorrer a literatura mais folhetinesca a respeito da obra de Picasso, constataríamos que as descrições convertem-se em uma verdadeira saga em vida: o imenso repertório e as incontáveis referências a que Picasso recorre nessas gravuras - odaliscas, mosqueteiros, personagens literários do século de ouro espanhol, entre Celestinas, Quixotes, majas etc. , temas e episódios bíblicos, cenas de teatro, alusões a ilustres pintores como Rembrandt e Rafael com suas modelos, e, por fim, Degas e as prostitutas nos bordéis - todos eles seriam, no derradeiro apagar das luzes, protagonistas de um sem fim de lembranças em disparo, cuja catástase é um imenso álbum de gravuras.

Nesse caso, nada melhor que a antiga metáfora do diário para designar o processo criativo em questão ${ }^{330}$. Coube ao crítico e curador britânico David Sylvester sentenciá-lo: "Picasso produziu o diário da vida erótica de um artista, um registro de obsessões com satisfações e frustrações e fantasias e parceiras particulares: eis que ele sobreviveu até os noventa anos e continuou produzindo aquele diário praticamente até o fim de sua vida"33r. E outra vez, as polêmicas e audaciosas declarações de Picasso só vinham a legitimar a comparação: "Eu pinto como outros escrevem sua autobiografia. Minhas telas, terminadas ou não, são como as páginas do meu diário" ${ }^{332}$, teria dito o artista, em I946, à sua então companheira Françoise Gilot.

Entre aqueles que veem a produção madura de Picasso como uma caderneta de confissões, é frequente que se evoque o tema da própria impotência do artista em suas

330 Segundo Green, a metáfora do diário para descrever a obra de Picasso foi empregada pela primeira vez no final da década de 1920 por Pierre-Quint, editor do escritor e amigo de Picasso Michel Leiris. Ao longo dos anos, ganhou força na bibliografia sobre o artista. Cf. GREEN, op. cit., p. 5-6.

331 Traduzido livremente, do original: "Picasso had produced a diary of an artist's erotic life, a record of obsessions with particular satisfactions and frustrations and fantasies and partners: he happened to survive into his nineties and he went on producing that diary almost to the end of his life.", in SYLVESTER, David. "End Game", in Late Picasso, Londres: The Tate Gallery, 1988, p. 137.

332 Repare-se que a declaração, como um todo, carrega algo da ansiedade em relação ao envelhecer e ao passar do tempo: "Je peins comme d'autres écrivent leur autobiographie. Mes toiles, finies ou non, sont les pages de mon journal, et en tant que telles elles sont valables. L'avenir choisira les pages qu'il préfère. Ce n'est pas à moi de le faire. J'ai l'impression que le temps passe de plus en plus rapidement. Je suis comme un fleuve qui continue à couler, roulant avec lui les arbres déracinés par le courant (....). J'entraîne tout cela et je continue. C'est le mouvement de la peinture qui m'intéresse, l'effort dramatique d'une vision à l'autre (...). J'ai de moins en moins de temps, et de plus en plus à dire. J'en suis arrivé au moment, voyez-vous, où le mouvement de ma pensée m'in téresse plus que ma pensée elle-même.". Cf. GILOT, Françoise; LAKE, Carlton. Vivre avec Picasso, Paris: Calmann-Lévy, 1965, pp. 116. 
últimas décadas de vida. Para Sylvester, as inúmeras gravuras de Picasso nessa época são "uma massa extraordinária de trabalhos sobre o tema da perda da masculinidade" 333 . Em uma linha semelhante, John Berguer dirá que nos últimos trinta anos de vida, Picasso que "amava as mulheres tanto quanto podia, encarou o absurdo de sua própria impotência relativa" 334 . Gert Schiff, por sua vez, defenderá que na série de gravuras Suite 347, a impotência de Picasso permitia que ele comentasse abertamente sobre a frustração masculina frente à disponibilidade da mulher ${ }^{335}$.

Murmúrios à parte, por mais sedutoras e verdadeiras que possam ser as diagnoses a nível psicobiogáfico, reúno todo esse exaustivo apanhado apenas com a intenção de constatar que a imagem de um Picasso ancião, impotente, desvairado, fantasioso e compulsivo passou a ser, em muitos casos, quase indivorciável das possibilidades de interpretação das séries Suite 347 e Suite 156.

Não pretendo sugerir que questões particulares tenham sido irrelevantes para o desenvolvimento das séries, é claro. Gostaria somente de enfatizar que em um processo que se estende ao menos desde a realização de Las Meninas em diante, voyeurismo e sexualidade não diziam respeito somente à vida pessoal de Picasso, mas eram para ele termos cada vez mais inseparáveis do repertório infinito da história da arte, que, por sua vez, era nada menos que o material primeiro para sua produção de gravuras naquele período.

Esse argumento não é exatamente inovador ou tampouco particularmente engenhoso. A recorrência de tramas voyeuristas na produção dos últimos anos de vida de Picasso faz com que a questão dificilmente passe desapercebida por aqueles que se dedicam a examinar sua produção derradeira. O caso é que, embora tenha se atentado para o fato de que voyeurismo e história da arte parecem ser esferas indissociáveis na produção madura de Picasso, a constatação vem amiúde a reboque da referida imagem do nonagenário Picasso como artista meio compulsivo meio impotente, fantasioso, enfim.

333 SYLVESTER, op. cit., p. 137. Traduzido livremente, do original: "extraordinary mass of work on the subject of loss of manhood".

334 Traduzido livremente, do original: [Picasso] "loved women as much as he ever had and he faced the absurdity of his own relative impotence. One of the oldest jokes in the world became his pain and his obsession-as well as a challenge to his great pride". Cf. BERGER, John. "An Old Man's Frenzy", Art International, 3 (Summer 1988), p. 24.

335 SCHIFF, Gert. "Picasso's Suite 347, or Painting as an Act of Love", in Picasso in Perspective. Englewood Cliffs e New Jersey: Prentice-Hall, 1976, p. 165. 
Considere-se, por exemplo, o que disse Timothy Anglin Burgard, hoje curador de arte americana do Museu de Arte de São Francisco:

O voyeurismo, o resultado final da impotência artística e fisiológica, é um tema explícito ou subjacente que costura muitas das variações de Picasso realizadas a partir de obras de artistas anteriores, incluindo As mulheres à beira do Sena (1950), de Coubert, Mulheres Argelinas (1954-5), de Delacroix, Las Meninas (1957) de Velázquez, Dejeneur sur I'herbe (1959-62), de Manet, Rafael e La Fornarina (1968), de Ingres, o Cristo apresentado ao povo (1970), de Rembrandt e as monotipias de bordel de Degas ${ }^{336}$.

A asserção de Burgard é clara e concisa: ainda que o voyeurismo seja explícita ou implicitamente um elo entre as diferentes apropriações que Picasso faz da história da arte, ele não é mais que o efeito (ou o resultado) de uma condição física e psicológica particular. Essa visão que subsume as tramas de olhares nas imagens à projeção do ego do artista é compartilhada por inúmeros estudiosos que se dedicaram à análise das gravuras do fim da vida de Picasso, e até mesmo exames atentos aos concernimentos da crítica feminista - para a qual o estudo sobre o olhar escopofílico é de suma importância - parecem estar de acordo quanto a esse ponto.

Talvez o veredito mais contundente a esse respeito tenha sido pronunciado por Charles Bernheimer em uma análise que, na verdade, se detém mais especificamente nas monotipias de bordel de Degas do que nas posteriores variações realizadas por Picasso ${ }^{337}$. Para o autor, as estampas oitocentistas, diferente do que a princípio possa parecer, operam um deslocamento do espectador masculino - isto é, do voyeur - confrontando-o com as prerrogativas que subjazem a sua posição voyeurística e, dessa forma, se recusam a ser apropriadas enquanto fantasia de dominação. No outro extremo:

336 Traduzido livremente, do original: "Voyeurism, the result of artistic and physical impotence, is an ouvert or underlying theme that links many of Picasso's variations after works by earlier artists, including Coubert's Young Women on Banks of the Siene (1950), Delacroix's Femmes d'Alger (1954-5), Velázquez's Las Meninas (1957), Manet's Dejeneur sur l'herbe (1959-62), Ingres' Raphael et la Fornarina (1968), Rembrandt's Christ Presented to the People (1970) and Degas' brothel's monotypes". Cf. ANGLIN BURGARD, Timothy. "Picasso and Appropriation", in: The Art Bulletin, Vol. 73, No. 3 (Sep., 1991), p. 489.

337 BERNHEIMER, Charles. "Degas's Brothels: Voyeurism and Ideology", in Representations, No. 20, Special Issue: Misogyny, Misandry, and Misanthropy (Autumn, 1987), pp. 158-186. 
As prostitutas de Picasso, em contrapartida, são as projeções voyeurísticas de um fantasiador (talvez impotente?) que converte o real em um teatro de alucinações privadas e imaginações eróticas [...]. O desejo da mulher, aparentemente em evidência nas imagens de bordel de Picasso, é exibido apenas em benefício do narcisismo masculino. Sua sexualidade está atrelada ao projeto de demonstrar a habilidade do artista-homem de criar o feminino como uma ficção estética. ${ }^{338}$

O que ocorre nas gravuras de Picasso, segundo Bernheimer, é uma "retorização da diferença sexual, talvez a mais sofisticada das estratégias de misoginia, que combina as contradições do voyeurismo e do fetichismo" 339 em um gesto de imposição de maestria da linguagem.

Ora, é difícil negar, de fato, que as gravuras de Picasso tiram partido de artifícios para demarcar a diferença sexual a partir da qual constroem a si mesmas. Mas será que devemos interpretá-las como meras ficções fantasiosas de natureza e efeito retórico, como ferramentas de controle (de abstração) masculina para a construção do feminino fetichizado, como testamento final ou como expressão das aventuras fantasiosas e desejos voyeuristas de um artista impotente que sucumbiu ao mito de si próprio?

Para responder à questão, proponho que nos detenhamos, pela última vez nesta dissertação, em algumas das gravuras em questão.

Comecemos por duas das gravuras que Bernheimer, ele próprio, escolhe examinar (figs. 8I e 82). As estampas são tão explícitas que, de início, talvez uma simples descrição daquilo que vemos dê conta de evidenciar as características que alicerçam a construção retórica da diferença sexual a que o autor se refere.

338 Ibid, p. 169-70. Traduzido livremente, do original: "Picasso's prostitutes are the voyeuristic projections of a (perhaps impotent?) fantasist who transforms the real into a theater of private hallucinations and erotic imaginings [...].Woman's desire, seemingly in evidence throughout Picasso's bordello images, is exhibited only for the benefit of male narcissism. Her sexuality is annexed to the project of representing the male artist's ability to create the feminine as an aesthetic fiction.

339 Ibid. p. 171, traduzido livremente do original: "This rhetorization of female difference may be the most sophisticated of misogynistic strategies, conflating the contradictions of voyeurism and fetishism". 
Tanto em uma como em outra, o corpo feminino é parte de um emaranhado de linhas altamente adornadas cujos limites não obedecem a padrões antropomorfos, mas à própria lógica do floreio torneado. "Olhos, mamilos e ânus se assemelham uns aos outros e parecem multiplicar-se vertiginosamente" ${ }^{340}$, exibindo-se sem pudor. Não sabemos quais órgãos pertencem a quais figuras: os tumefatos membros embaralhados são todos parte de uma aglomeração indivisível, cujo volume se constrói estritamente a partir de um tratamento linear que prescinde de massas ou manchas. Talvez por isso, por mais opulentos, roliços e bojudos que sejam os braços, pernas, seios e nádegas das figuras representadas, a sensação transmitida é de leveza e mesmo leviandade. As feições não carregam traços característicos de um tratamento particularizado: o rosto das mulheres é, antes, uma espécie de abstração paramentada que sustenta olhos débeis, amendoados e estrábicos.

Não se pode afirmar que o mesmo traço de indeterminação ou abstração, em contrapartida, predomine na representação das poucas figuras masculinas nessas gravuras. Em ambas as estampas, é fácil reconhecer os atributos fisionômicos de Degas nas figuras masculinas, uma silhueta acantoada à esquerda ou à direita da composição, que se retrai esquiva e hieraticamente como se temesse o espetáculo de formas femininas que observa com curiosidade. Ele é retratado à maneira dos clientes nas monotipias do próprio artista francês (das quais onze se tornaram, posteriormente, possessão de Picasso): com expressões austeras, roupas escuras, olhar fixo, corpo rígido e ereto, porém, vacilante, temeroso em penetrar no universo feminino que ele se limita tão somente a observar.

Entretanto, o que o olhar fixo da figura de Degas focaliza é, de acordo com Bernheimer, um universo bastante distinto daquele que ele mesmo havia registrado em suas monotipias pouco menos de cem anos antes ${ }^{34}$. Nas monotipias de Degas, a assertiva clareza e a brutal exposição do corpo feminino não fazem da sexualidade feminina "um texto nem um pouco mais legível do que quando disfarçado sob a máscara de identidades sexuais mais aceitáveis" ${ }^{342}$. Diversos fatores incluindo-se o meio e a técnica empregados tornam os elementos figurados ambíguos e incertos, de modo a causar desconforto no

340 BERNHEIMER, op. cit., p. 168. Traduzido livremente, do original: "Eyes, nipples, and anuses resemble each other and seem to multiply vertiginously".

341 Ibid.

342 Ibid. p. 160. Traduzido livremente, do original: "This brutal explicitness, however, does not make the text of female sexuality any more legible than it was when disguised under the masks of more acceptable social identities". 
espectador, que se vê estranhamente obrigado a lidar com sua posição de voyeur. Para Bernheimer, por mais explícitas que sejam essas monotipias, sua ambiguidade as impede de ser pornográficas ${ }^{343}$.

Já as gravuras de Picasso, segundo ele, embora sejam ainda mais explícitas que as monotipias de Degas ${ }^{344}$, não são por isso igualmente ambíguas: pelo contrário, o que há nelas é uma forma de exibicionismo existente somente para saciar a sede de controle e regozijo masculino. Hollis Clayson, em uma interpretação que se põe de acordo com a de Bernheimer, dirá algo semelhante: o desejo das prostitutas é exibido apenas como forma de satisfizer o narcisismo masculino, e não é senão a mais refinada das expressões misóginas de fantasias de voyeurismo e dominação por parte de Picasso ${ }^{345}$.

Há, ao meu ver, ao menos dois problemas associados a essa interpretação. Em primeiro lugar, tanto Benheimer quanto Clayson buscam compreender as gravuras de Picasso sob uma perspectiva intertextual, como se elas fossem uma sorte de discurso construído a partir das monotipias de Degas, ou, dito de outro modo, como se correspondessem a uma espécie de intepretação desse material. Charles Bernheimer, cuja formação e atuação circunscreve-se majoritariamente no campo da literatura comparada, fala diversas vezes da legibilidade das gravuras de Picasso ${ }^{346}$ : elas são, para o autor, uma leitura ou uma interpretação da série de monotipias de bordel de Degas.

Hollys Clayson, por sua vez, refere-se explicitamente a uma intertextualidade histórica e estrutural entre ambas as séries ${ }^{347}$. Nessa perspectiva, as gravuras de Picasso se

343 Ibid., p. 175. Berheimer se utiliza de uma distinção entre erotismo e pornografia referenciando-a, sem necessariamente debatê-la. Penso que a questão carece de discussão, uma vez que os limites entre uma esfera e a outra são arredios, e geram polêmica entre as diversas correntes que se reivindicam como feministas.

344 Outros autores notaram o impulso de Picasso por tornar completamente inequívoco aquilo que Degas havia deixado subentendido. Considere-se, por exemplo: "In all of these prints, Picasso was flagrant where Degas suggested". In: COWLING, 2010, op. cit., p. 239.

345 CLAYSON, Hollis. In the Brothel, in "Painted Love: prostitution in French art in Impressionist Era", Los Angeles: The Getty Research Institute, 2003, pp. 27-56; mais especificamente pp. 48-50.

346 Considere-se, por exemplo, a frase citada anteriormente, referenciada na nota 193, que reporta-se à legibilidade da sexualidade feminina nas gravuras. Ademais, Berheimer mobiliza também termos como "subtexto", entre outros derivados da literatura, para compreender as gravuras em questão. Cf. BERNHEIMER, op. cit., p. 160.

347 CLAYSON, op. cit., p. 50. 
tornam, via de regra, vereditos sobre as monotipias de Degas e, mais especificamente, sobre a sexualidade controversa do artista. Em suas abordagens, ambos os autores levam em conta a conhecida curiosidade de Picasso pela circunspecta vida sexual de Degas, e entendem a referência do artista às monotipias de bordel como uma espécie de sentença (fictícia e fantasiosa) sobre a pretensa abstinência ou disfunção sexual de Edgar Degas.

Explico-me. De fato, conta-se que Picasso, em seus últimos anos de vida, nutria grande fascínio pelas monotipias de bordel de Degas. Em sua coleção, possuía onze delas, pertencentes hoje ao acervo do Museu Picasso Paris. Sabemos que nos primeiros meses de 1958, logo após produzir suas variações de Las Meninas, Picasso estava em vias de adquirir a oitava de suas onze monotipias, e que, ao contrário do que costumava ocorrer normalmente, desprendeu um esforço considerável para tanto ${ }^{348}$. Ainda que Picasso nunca tenha sido exímio colecionador de obras antigas, essas imagens ocupavam um lugar privilegiado no pódio de seu acervo pessoal: conforme relatam muitos de seus amigos e biógrafos ${ }^{349}$, Picasso, nos últimos anos de sua vida, ao comentar seu renovado interesse em mergulhar na produção gráfica, amiúde insistia em exibir seus próprios exemplares das monotipias de Degas, recrutando à baila uma longa discussão sobre a personalidade, a sexualidade ou sobre a suposta abstinência e a presumida homossexualidade que rondavam as especulações sobre a vida íntima do artista francês - especulações estas que, em larga medida, consolidavam as acusações de misoginia que lhe foram outorgadas desde o século XIX, quando o crítico Joris-Karl Huyssmans atribuiu ao traço iconoclasta de sua obra marcas de crueldade em relação às figuras femininas retratadas ${ }^{350}$.

348 Para mais informações sobre a transação comercial e pelo interesse de Picasso na monotipia em questão, cf. COWLING, Elisabeth, "Picasso's Maisons Closets", em COWLING; KENDALL, Richard. Picasso Looks at Degas. Williamstown: Sterling and Francine Clark Art Institute, Museo Picasso, 2010, p. 228.

349 Para uma reunião de apontamentos de biógrafos de Picasso (entre eles Rubin, Daix e Brassaï) a esse respeito Cf. ibid., pp. 211-233.

350 Em 1889, Certains, texto critico publicado por Joris-Karl Huymans, faz menção à crueldade de Degas em representar banhistas e trabalhadoras em posições humilhantes e degradantes, frequentemente associadas a cenas de higiene íntima. Tais interpretações foram reforçadas por grande parte da crítica de Degas ao longo do tempo. Leituras recentes refutam essa visão, sugerindo que respostas como a de Huysman configuram uma defesa tipicamente masculina frente à auto-suficiencia das mulheres retratadas. Charles Bernheimer alude às interpretações revisionistas em questão, especificamente às de: ARMSTRONG, Carol. Odd Man Out: Readings of the Work and Reputation of Edgar Degas. Princeton University Press, 1986; LIPTON, Eunice. Looking into Degas: Uneasy Images of Women and Modern Life, Berkeley, Los Angeles, and London: University of California Press, 1986. 
Como prova do vivaz interesse de Picasso pelo diz-que-diz em relação à sexualidade de Degas, Clayson evoca um episódio narrado por Rubin no qual Picasso lança a questão: "O que você acha que Degas estava fazendo nesses lugares?" 351.

Para a autora, a resposta a essa pergunta seriam, precisamente, as gravuras realizadas em I97I, nas quais o Degas é figurado como um outsider, assistindo o espetáculo de exibição das prostitutas, mas nunca participando ${ }^{352}$. Charles Bernheimer defenderá algo parecido quando, ao comentar a postura retiscente dos clientes nas monotipias de bordel Degas, se questionará:

Tal resistência deveria ser lida psicanaliticamente, como decorrência do medo em relação à sexualidade castrada da mulher? Será que os clientes resistem às incitações ao desejo e à posse por conta de uma repulsa inconsciente ao que há de inquietante naquilo que não se vê? Esta foi a interpretação dada a estas imagens por Pablo Picasso, que em $1971 \mathrm{fez}$ uma série de quarenta gravuras excepcionais que [...] frequentemente retratam Degas, uma figura alter ego, numa posição muito semelhante à dos clientes nas duas monotipias que acabamos de discutir. ${ }^{353}$

A atitude de Picasso - que imputa a Degas a posição de um voyeur que assiste sadicamente à exibição das prostitutas no bordel, convertendo-o em uma espécie de alter ego de sua própria condição de senilidade e impotência- corresponderia, nesse caso, à típica reação masculinista frente às monotipias de bordel identificável em Huysmanns,

351 Citado em CLAYSON, op. cit., p. 49, do original RUBIN, William. "Visits with Picasso at Mougins", Art News 27, no. 6, Verão 1973, pp. 42. Evocando o mesmo diálogo com Rubin, Elizabeth Cowling observa que Picasso teria dito: "It's well known, of course, that Degas did not have normal relations with women. He was a sort of neuter. In fact there is an essay by Paul Valery in wich there is a vague suggestion that Degas was a repressed homossexual". Citado em COWLING, op. cit., p. 239.

352 CLAYSON, op. cit., p. 49.

353 BERNHEIMER, op. cit., p. 167. Traduzido livremente, do original: "Should this resistance be read psychoanalytically as due to a fear of woman's castrated sexuality? Do the clients resist the incitements to desire and possession because of an unconscious horror of the uncanny unseen? This was the interpretation given to these images by Pablo Picasso, who in 1971 made a series of forty superb etchings that [...] frequently portrays Degas, an alter-ego figure, in a position much like that of the clients in the two monotypes we have just discussed". 

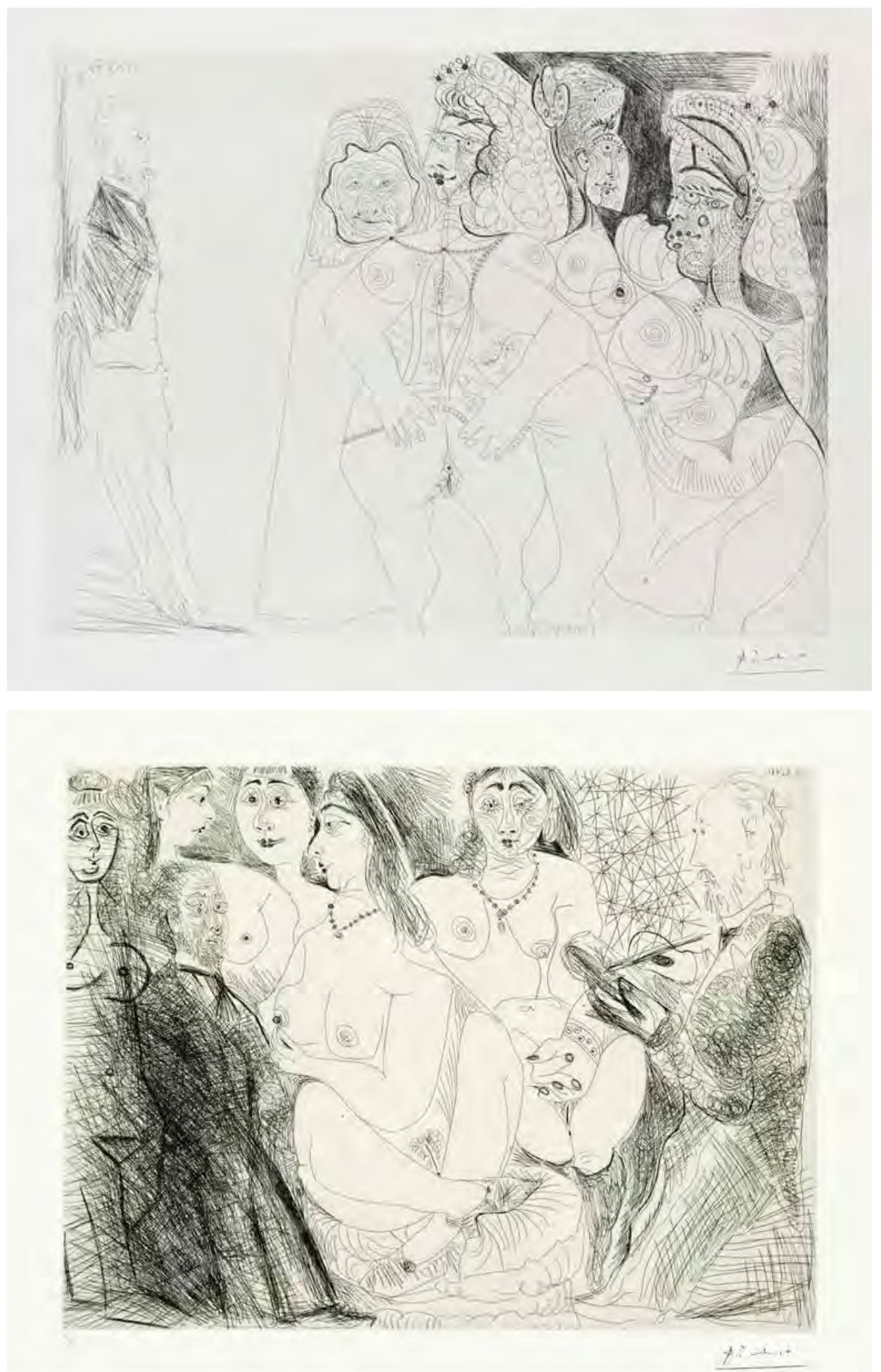

81 Pablo Picasso

Degas em meio às prostitutas 17 de março de 1971

Gravura em metal

$50 \times 65 \mathrm{~cm}$
82 Pablo Picasso

Degas desenhando-se a si mesmo, vestido, em meio às prostitutas

13 de março de 1971

Gravura em metal

$50 \times 65 \mathrm{~cm}$ 
em Paul Valery ${ }^{354}$ e em uma plêiade de autores que viram no traço iconoclasta de Degas vestígios de crueldade ou mesmo de uma sexualidade mal resolvida em relação às mulheres. Tal atitude, para Bernheimer, obedece a um mecanismo de culpa e compensação que resguarda os próprios autores (homens, observadores das gravuras) de seus desejos misóginos e voyeuristas e de sua ânsia por controle e dominação, tributados, por delegação, a Degas e à sua obra.

O curioso é que tanto Berheimer quanto Clayson buscam contestar os princípios que fundamentam esse tipo de abordagem da obra e da reputação de Degas. Em contrapartida, deliberadamente atribuem a Picasso aquilo que se esforçam por refutar em Degas ${ }^{355}$, como se as variações do espanhol viessem inequivocamente a reforçar o conjunto de pressupostos que embasam a visão dominante a respeito da obra do francês. Ao fazê-lo, alinham-se com as interpretações mais consagradas sobre as gravuras de Picasso, que concebem a figuração do corpo feminino e a atitude voyeurista dos espectadores masculinos nas imagens, entre outras coisas, como projeção da impotência e mesmo da misoginia do velho Picasso ${ }^{356}$.

354 Bernheimer constrói seu texto a partir da crítica à leitura que Paul Valery faz da obra de Degas. Cf. BERNHEIMER, op. cit.; VALERY, Paul. Degas, dança, desenho. São Paulo, Cosac Naify, 2012.

3550 autor defende, inclusive, que as prostitutas de Picasso conservam um fundo misógino característico da imagem da cortesã do século XIX. Cf. BERNHEIMER, op. cit., p. 170. Cabe destacar também que Norma Broude, autora de uma das mais conhecidas leituras feministas da obra de Degas, escreveu, em 1980, na ocasião da grande retrospectiva de Picasso no Museu de Arte Moderna, uma crítica em que denunciva a obra de Picasso por estar enraizada nos mitos, fantasias e medos que caracterizam as últimas décadas do século XIX, e por não mais que reiterar os valores hostis à mulher, encarnando os estereótipos duais próprios àquele período. Cf. BROUDE, Norma. "Picasso, Artist of the Century (Late Nineeteenth)". In: Arts, outubro de 1980, pp. 84-86.

356 A misoginia de Picasso, frequentemente associada à sua origem andaluz, foi diversas vezes comentada por John Richadson, um dos mais célebres biógrafos do artista. Considere-se, por exemplo, sua asserção a respeito de Grande Nu na Poltrona Vervemlha (Olga), de 1929 e de outras pinturas da mesma época: "The anger in these images suggests that Picasso suffered from the atavistic misogyny toward women that supposedly lurks in the psyche of every full-blooded Andalusian male". In: RICHARDSON, John. A Life of Picasso: The triumphant years 1917-1932, Nova York: Alfred A. Knoft, 2007, p. 669. Cabe destacar, ainda, que William Rubin, em uma das mais consagradas analyses da genealogia da pintura Les Demoiselles d'Avignon, de 1907, refere-se diversas vezes ao profundo medo e de Picasso em relação ao corpo feminino, que se plasma em uma relação contraditória de atração e repulsão. Cf. RUBIN, William. "The Genesis of Les Demoiselles d'Avignon", in Studies in Modern Art: Les Demoiselles d'Avignon, eds. William Rubin e Hèlene Seckel, Nova York: The Museum of Modern Art, 1994, pp. 13-145. 
Seja como for, ainda que acusações que alicerçam essas interpretações certifiquem lealdade a um fundo psicanalítico que trespassa a produção de Picasso nos últimos anos de vida, será possível confiar exclusivamente em uma interpretação nelas pautada? E ainda, será mesmo adequado considerar as gravuras desse período desde uma perspectiva intertextual ${ }^{357}$, como se elas fossem uma espécie de discurso de resposta às monotipias de Degas?

Daí decorre o segundo problema ao qual me referia anteriormente. Por mais tentador que possa parecer, as estampas de Picasso não são meramente uma leitura das monotipias de bordel, nem tampouco resposta inequívoca a elas. Pois ao fazer da própria história da arte seu material mais tangível, Picasso reduz o repertório da tradição à condição de imagem, retirando-lhe a espessura histórica e sua significação em nível imediato. Com isso não pretendo dizer que o procedimento em questão prescinda de implicações ideológicas, é claro: sugiro apenas que o postulado de que as imagens estão ligadas a objetos referenciais - a temas iconográficos, a Degas e sua reputação, a prostitutas de carne e osso, etc. - é, no mínimo, passível de contestação quando o que essas imagens parecem fazer, dentre todas as possibilidade que lhe são oferecidas, é dirigir-se a um repertório de imagens previamente instituído ${ }^{358}$. Em outras palavras, não podemos ignorar que quando as imagens se voltam simultaneamente a referentes e a códigos

357 Embora Hollis Clayson reivindique uma dimensão intertextual entre as séries de bordel de Picasso e Degas, me parece que sua análise (à semelhança da de Bernheimer) não considera as estampas estritamente sob essa perspectiva, ao mesmos se considerada a intertextualidade no horizonte das contribuições de Julia Kristeva, responsável pela introdução do conceito na década de 1960. Kristeva, ao referir-se ao postulado dialógico de Bakhtin, propõe que "todo texto se contrói como um mosaico de citações, todo texto é a absorção de outro texto. Em lugar da noção de intersubjetividade, instala-se a de intertextualidade, e a linguagem poeetico lê-se pelo menos como dupla". Cf. KRISTEVA, J. "A palavra, o diálogo e o romance", em Introdução à semanálise. Trad. Lúcia Helena França Ferraz, 2a. ed., São Paulo: Perspectiva, 2005, pp. 67-8. Repare-se que na análise de Clayson, o que se leva em conta é precisamente a esfera intersubjetiva em que as gravuras se inscrevem. Considerar as estampas como intertexto requeriria destinar atenção mais detida ao emaranhado de citações a partir do qual as imagens se constróem, sem necessariamente atrelá-las a uma condição de autoria sobredeterminante.

358 Cabe assinalar que uma distinção semelhante permeia, hoje, nossa compreensão sobre o fenômeno da arte pop e as genealogias que dela derivaram. Hal Foster, em seu célebre ensaio "O Retorno do Real" discute os dois modelos básicos de representação que marcam tal distinção, bastante recorrente na literatura sobre arte contemporânea: de um lado, há um modelo que compreende as imagens como termos ligados a referentes (temas iconográficos, coisas do mundo real) e de outro lado, há aquele que entende as imagens como simulacros, como códigos autorreferenciais. Cf. FOSTER, Hal. "O retorno do real", in O retorno do real, trad. Célia Euvaldo, São Paulo: Ubu, 2017, pp. 122-157. 
auto-referenciais, sua significação torna-se oblíqua. Sem contar que a alusão a Degas é apenas uma dentre as tantas que povoam as gravuras do final da vida do artista, que servem-se dos mais variados elementos extraídos do vasto repertório da arte barroca, da pintura pompier, da literatura do século de ouro na Espanha, do folclore castelhano, da cultura de massas e da fantasia erótica para entretecer a urdidura de tramas de olhares (se não sempre) quase sempre voyeuristas.

Dito de forma mais simples, ao fazer alusão a Degas (que é uma dentre outras), Picasso não necessariamente trata exclusivamente da figura de Degas, de seus medos ou de sua sexualidade em nível discursivo. Tampouco se restringe a questões que dizem respeito a sua própria ânsia sexual, tão somente por encontrar em Degas um alter ego para seus temores senis. Se a operação realizada por Picasso se inscreve, como observa Hollis Clayson, no âmbito intertextual, ela corresponde não apenas a uma releitura das monotipias ou da reputação de Degas (e, por conseguinte, de Picasso e de suas fantasias privadas), mas remonta a uma forma paródica de apropriação de todo o repertório da tradição figurativa ${ }^{359}$. Não à toa, muito se falou de um tom ácido, cético, irônico e auto -irônico que perpassa a produção de Picasso nesse período ${ }^{360}$. Esse tom, por si só, não está alheio a um tratamento afetivo particular, a um páthos diletante ou mesmo a um sentimentalismo pessoal, por mais paradoxal que isso possa parecer à primeira vista. Pois o empréstimo delidebado das mais diversas referências e formas da tradição figurativa faz convergir forças aparentemente contraditórias de homenagem, veneração, tributo e

359 O tom paródico dessas gravuras não exclui o que pode haver de pastiche ou de formas diversificadas de apropriação do material da tradição, esferas que evidentemente se sobrepõem na formação das imagens. Cabe sinalizar que é relativamente frequente que se note o tom paródico das gravuras do fim da vida de Picasso, ainda que esse traço determinante quase nunca seja explorado enquanto tal. Dentre aqueles que o notaram, estão SCHIFF, Gert, Picasso's Suite 347: Painting as an Act of Love, in op. cit., p. 164; BARR-SHARRAR, Beryl. "Some Aspects of Early Autobiographical Imagery in Picasso's Suite 347", p. 518. A discussão sobre paródia, modernidade e pós-modernidade é extensa, e talvez um estudo com esse enfoque e detido nas obras maduras de Picasso pudesse render frutos tanto à nossa compreensão do trabalho do artista, como também ao próprio entendimento que temos dos problemas centrais que atravessam a arte e a cultura contemporânea. Cumpre assinalar que entendo "paródia", aqui, mais ou menos nos termos estabelecidos por Linda Hutcheon, como uma forma paradoxal de transgressão autorizada de dupla orientação (a uma obra de arte e às convenções que ela estabelece em termos de linguagem), frequentemente irônica ou satírica ao mesmo tempo em quase reverencial. Cf. HUTCHEON, Linda. Uma Teoria da Paródia, Lisboa: Edições 70, 1985.

360 Cf. ANGLIN-BURGARD, op. cit., p. 242; SCHIFF, Picasso's old, age, op. cit., p. 125; BARR-SHARRAR, Beryl, op. cit., p. 528. 
de provocação, irreverência e insubordinação, o que expressa uma atitude ambivalente em relação ao material do qual se parte.

Por mais tentador que seja diagnosticar esse ethos de admiração e de escárnio como sintoma de acontecimentos de fundo psicobiográfico, não podemos ignorar seu pertencimento ao reino da linguagem. Não se trata apenas de um resgate nostálgico de modelos do passado ou de lembranças e memórias afetivas: trata-se, antes, de uma recodificação de formas, que enceta a insubordinação no coração da reverência ao passado. Nesse caso, são as convenções, tanto quanto as obras individuais, que são parodiadas. E uma dentre essas convenções, sem dúvida, é a prerrogativa masculina do olhar voyeurista.

O brado provocativo que atinge tanto as imagens das quais se parte quanto as convenções linguísticas que compõem sua estrutura é uma face que escapa aos argumentos de Bernheimer e de Clayson. Quando defendem que as gravuras de Picasso são paradigmáticas da mais refinada das atitudes misóginas na qual convergem voyeurismo e fetichismo, ambos baseiam-se no fato de que Picasso, em suas gravuras, retrata Degas e as figuras masculinas em posições semelhantes às dos clientes reticentes nas monotipias de bordel do século XIX, ao passo que converte em exibição o que nas monotipias estava associado a uma postura de absorção das mulheres com relação a seu próprio corpo.

De fato, nessas gravuras Picasso frequentemente escancara as poses que recolhe do vasto repertório que lhe ofereciam as monotipias de Degas de sua própria coleção. Repare-se, por exemplo, em como as pernas escancaradas da figura feminina de meias brancas e pulseiras de uma das pranchas de Suite I56 (fig. 85) são como uma variante escancarada da pose da prostituta de braços cruzados na monotipia À espera (fig. 83). $\mathrm{Ou}$, então, em como o corpo estirado da segunda figura feminina nessa mesma gravura é uma versão exibicionista daquele da mulher que descansa na monotipia $O$ repouso (fig. 80). Observe-se, ainda, como as nádegas da prostituta em inflexão na monotipia igualmente intitulada À espera (fig. 87) recordam o gesto explícito da mulher na gravura Bordel. Degas com seu álbum, cafetina e puff marroquino(fig. 88).

Repare-se também, no entanto, que quando Picasso se apropria de todo esse repertório de poses das prostitutas de Degas para convertê-las em desinibição, o faz de modo a acentuar a orientação divergente das zonas erógenas do corpo feminino, exposto tanto ao observador em quadro quanto ao observador fora dele.

A exibição despudorada dos órgãos e atributos sexuais das mulheres nessas imagens - que tanto incomodou a Bernheimer e Clayson - não está alheia ao artifício de flagrante 
e testemunha ocular que havíamos examinado no primeiro capítulo. Picasso conhecia muito bem a função dramática que o espectador na obra tem para implicar o observador fora delas: se Degas é um voyeur retraído, nós, por remissão, também o somos. Se Degas é, como muitas vezes foi dito, ridicularizado, nós também o somos. Não por acaso, as mulheres nessas gravuras adotam uma postura estrábica, como se olhassem simultaneamente para direções opostas. Muitas vezes, elas parecem olhar para Degas e escancarar-se para nós, espectador. Outras vezes, parecem olhar para nós e escancarar-se para Degas. Ou ambos ao mesmo tempo, cada um de seus olhos para um lado. Há ainda o uso deliberado do "olho egípcio" em mulheres de perfil - uma forma herdada da arte helênica e de seus precursores egípcios - que obedece, nessas imagens, ao desejo de construir um rosto de direcionamento ambíguo, capaz de endereçar-se, em divórcio, a lugares disparatados. Trata-se de um artifício obtido a duras penas na obra de Picasso que, como demonstrou Leo Steinberg ${ }^{361}$, transforma-se em um jogo de malabarismos sem fim.

A orientação divergente do olhar e do corpo das figuras femininas é, certamente, uma forma de expor e flertar e mesmo de satirizar com as prerrogativas masculinas do olhar na cultura figurativa - com as mesmas premissas que as monotipias de Degas magistralmente colocam sob tensão, como o amplo debate acerca de voyeurismo em sua obra veio a constatar.

Nesse caso, o poder deliberado de flexibilizar, contorcer, tornar elástico e de moldar o corpo da mulher nas imagens não responde somente a uma imposição de maestria a bel prazer ou à vontade de construir o feminino de acordo com a capacidade masculina de abstração ${ }^{362}$, como se correspondesse a um desejo de crueldade em relação à carne em estado bruto.

Picasso era tão fascinado e aficionado por temas afetivos de sua memória - que são também temas consagrados do repertório da história da arte - quanto por repetir incessantemente sua articulação convencional, explorando à exaustão toda e qualquer combinação possível do que neles subjaz como premissa. Nesse processo, não passam incólumes os ruídos causados por inversões e variações que desestabilizam os postulados dos quais se parte. Lembremo-nos de suas inúmeras obras que nos colocam frente ao tema

361 STEINBERG, "Mulheres Argelinas de Picasso em Aberto", em Outros Critérios, op. cit., p. 247-8.

362 BERNHEIMER, op. cit., p. 170. 
do pintor e de sua modelo, um bordão amiúde elevado à condição de "tema picassiano": na maior parte das vezes, imagens do pintor frente à modelo, ambos separados por um quadro que é tanto ponte como barreira ou linha de separação e demarcação de esferas que se combinam segundo uma lógica implicitamente hierárquica. Ele a observa, ela se exibe. Ele a pinta, ela descansa adorcemida. Ele a pinta, ele a penetra. Ele a pinta, ela se expõe e se oferece. Ele, por vezes, é um homem misterioso, vestido de negro. Por vezes, é apenas um velho asqueroso. Ela é, por vezes, uma figura robusta, de formas torneadas, e, por vezes, uma abstração geométrica. Mas há também inversões. Por vezes, o jogo de exibição e observação torna-se um carnaval de máscaras, a modo goyesco. Por vezes, o pintor converte-se em um macaco. Por vezes, é a mulher quem pinta e o homem, aquele observado. Ela é a artista, ele o modelo. Essas são as combinações mais satíricas, desabusadas e jocosas, como se valessem-se do humor para compensar o desvio da norma.

A capacidade de combinar e recombinar componentes como a assimetria entre os gêneros, o voyeurismo e a exibição do corpo mobilizando-os como radicais livres em um jogo obsessivo de intermináveis variações passa por um franco reconhecimento (por meio da incorporação) das injunções que as sustentam. É isso, precisamente, que permite o comentário irônico, que ri de suas próprias premissas ao mesmo tempo em que as expõe e as reverencia. Mas elas estão aí, disponíveis, e não são um mistério para ninguém: o pintor, a modelo, as prostitutas, o voyeur, a figura do próprio Picasso entre tantos elementos e motivos iconográficos. Todos são conhecidos, articulados repetidamente como em um jogo cujo fim jamais se alcançará. Não há verdade a ser revelada. Não há impulso redentor. O trabalho, a partir de um certo ponto, se faz como se estivesse no interior de um labirinto no qual todas as saídas parecem possíveis mas somente enquanto variações enclausuradas de um caminho único, uma busca infinita por recombinar, à maneira de montagem, tudo aquilo que subsiste enquanto convenção nos próprios temas afetivos que marcaram a extensa produção de Picasso - temas que, como dissemos, são também consagrados no vasto repertório da tradição, incorporados na condição de imagem. Pareceria uma empreitada ilustre de rememorar a própria trajetória artística, se por trás do fundo glorificante não houvesse também um trabalho de Sísifo, que ergue e faz rolar incessantemente a pedra angular de toda a cultura figurativa ocidental. 


\section{Ponto de fuga, ponto final}

Entre os anos de 197I e 1972, enquanto Picasso produzia suas gravuras da Suite 156, havia outro motivo bastante recorrente em sua obra: o da mulher de vagina à mostra, que Leo Steinberg denominou fizgigs (fig. 92 - 94) ${ }^{363}$. Elas são figuras femininas isoladas, de pernas escancaradas, repletas de floreios gráficos, desprovidas de trato e de beleza, sem qualquer pretensão à nobreza e à alta cultura, "assinaturas gestuais, como arabes$\cos ^{\prime 364}$, nas palavras de Steinberg .

A frequência dessas figuras na produção de Picasso aumenta consideravelmente durante os últimos anos de vida do artista. Segundo levantamento realizado por Steinberg 365 , a proporção de fizgigs durante os primeiros semestre de I97I é consideravelmente baixa apenas $14 \%$. Ao longo dos próximos seis meses, de julho a dezembro, a proporção de fizgigs aumenta para 2I,5\%. Finalmente, nos I 47 desenhos e pinturas realizados durante os últimos seis meses da produção de Picasso nada menos de $43 \%$ apresentam fizgigs.

Por mais que reconhecessse que muitos poderiam ser os fatores responsáveis pelo fenômeno fizgig na obra de Picasso (até mesmo a pornografia, talvez), Steinberg preferiu manter possíveis coeficientes externos arquivados em sobrestado para tratar da temática como algo gerado internamente. Imagens de mulheres arreganhadas, evidentemente, estavam presentes na obra de Picasso há um bom tempo: elas aparecem desavergonhadamente por toda a série de gravuras Suite 347, participando de ambientes institucionais - harém, bordel, palco, circo ou ateliê - ou de ações concretas (raptos, coqueteio, sedução, olhar-se no espelho, pentear os cabelos, enfim) em um mundo que as domestica. Mas as fizgigs, para Steinberg, são de outra ordem. Elas não compartilham o espaço com mais ninguém, são presenças singulares de existência momentânea - "rápida como uma pirueta" - toda ela voltada a seu imaginador, o recluso e nonagenário Picasso. Elas são como amuletos que agem contra o fenecimento derradeiro: "um solene documento na desmitologização da morte" ${ }^{666}$. "Vejo as fizgigs fantasmas do fim da vida de Picasso como um tipo de auto-ajuda" ${ }^{367}$, Steinberg escreverá.

363 STEINBERG, Leo. "O fim de partida de Picasso", trad. Julia Vidler, in ARS, Vol. 5 N. 9 (2007), pp. 25- 35.

$\begin{array}{ll}364 & \text { Ibid., p. } 30 . \\ 365 & \text { Ibid., p. } 37 . \\ 366 & \text { Ibid., p. } 33 . \\ 367 & \text { Idem. }\end{array}$


Pode ser, de fato, que as fizgigs estejam associadas ao processo de franco envelhecimento de Picasso e que tivessem função apotropaica para ele. Gostaria, no entanto, de atentar para questões de outra ordem.

No mesmo período em que a presença dessas figuras é esmagadora, a recorrência de imagens que a pelavam à silhueta de Degas era também considerável, ao menos no que concerne à obra gráfica - que, por sua vez, condensava grande parte de sua produção. Um simples recenseamento no acervo do Museu Picasso Barcelona (que possui um exemplar de todas as gravuras realizadas por Picasso desde a morte de seu amigo Sabartès até o final de sua vida) nos mostra que a figura de Degas está presente em 38 das IO2 gravuras realizadas em I97I.

Não se trata apenas de mera coincidência, ou ao menos isso me parece. Pois ainda que as fizgigs sejam bastante diferentes das mulheres que se exibem na Suite 347, elas recordam estranhamente as prostitutas de orientação divergente das gravuras que aludem a Degas. É claro que, nestas últimas, as mulheres - de modo mais ou menos semelhante às figuras femininas em Suite 347 - encontram-se em bordéis, rodeadas de bajuladores e observadores a prestar-lhes reverência. Há, no entanto, algo que faz com que as mulheres nessas gravuras se pareçam mais às fizgigs que as mulheres nas estampas da Suite 347: elas não estão incorporadas a nenhuma ação em concreto como na série de gravuras anterior. Exibição e observação são os dois únicos acontecimentos que regem as cenas apresentadas. O propósito das figuras femininas parece unicamente o de exibirse e arreganhar seus genitais a quem as observa.

Nesse caso, o observador é tanto uma figura no interior das imagens(Degas) quanto alguém que existe no exterior delas, nós mesmos. Por isso a orientação divergente do corpo feminino, mapeado em torno de suas zonas erógenas. No caso das fizgigs, toda e qualquer divergência no endereçamento dessas figuras é eliminada. É como se elas fossem a forma condensada daquilo que aparece nas gravuras de bordel de Picasso, a forma isolada e desnuda do que antes era mediado. Nessas imagens, Picasso elimina qualquer elemento interno que remeta ao olhar e, frente a isso, redireciona o corpo apresentado frontalmente para que atinja unicamente a nós - os espectadores. Ao fazê-lo, deve despir-se do tom paródico que se interpunha entre observador e imagem. Nesse caso, a relação assimétrica entre ver e ser visto é tão acentuada que parece mesmo deixar de existir, como se o elo que une as ações fosse de tal modo apertado que pudesse atar ambas as ações em um conglomerado de fronteiras indefinidas. Abolidas as mediações, ver e exibir-se convertem-se 

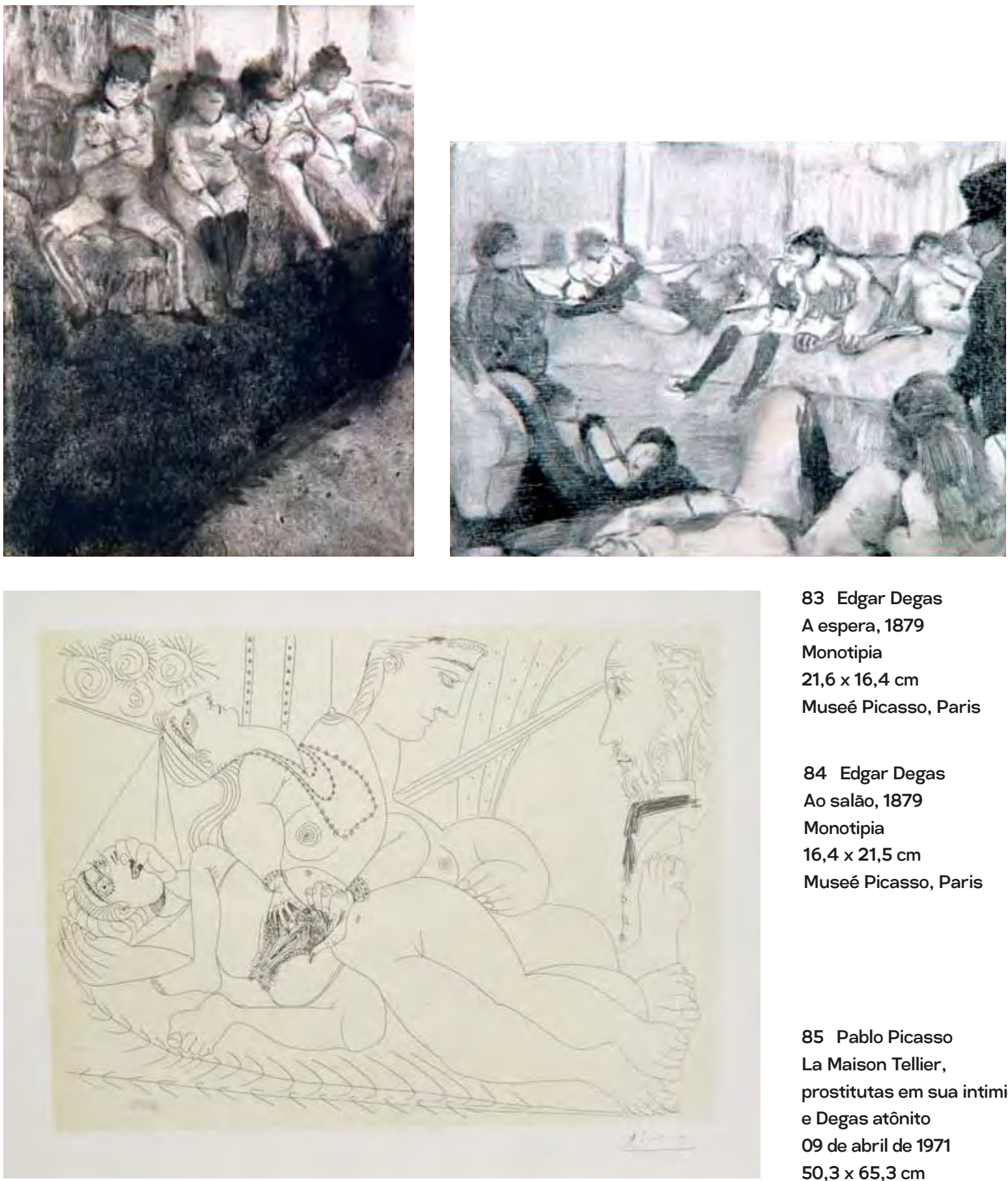

83 Edgar Degas

A espera, 1879

Monotipia

$21,6 \times 16,4 \mathrm{~cm}$

Museé Picasso, Paris

84 Edgar Degas

Ao salão, 1879

Monotipia

$16,4 \times 21,5 \mathrm{~cm}$

Museé Picasso, Paris

85 Pablo Picasso

La Maison Tellier,

prostitutas em sua intimidade e Degas atônito

09 de abril de 1971

$50,3 \times 65,3 \mathrm{~cm}$ 

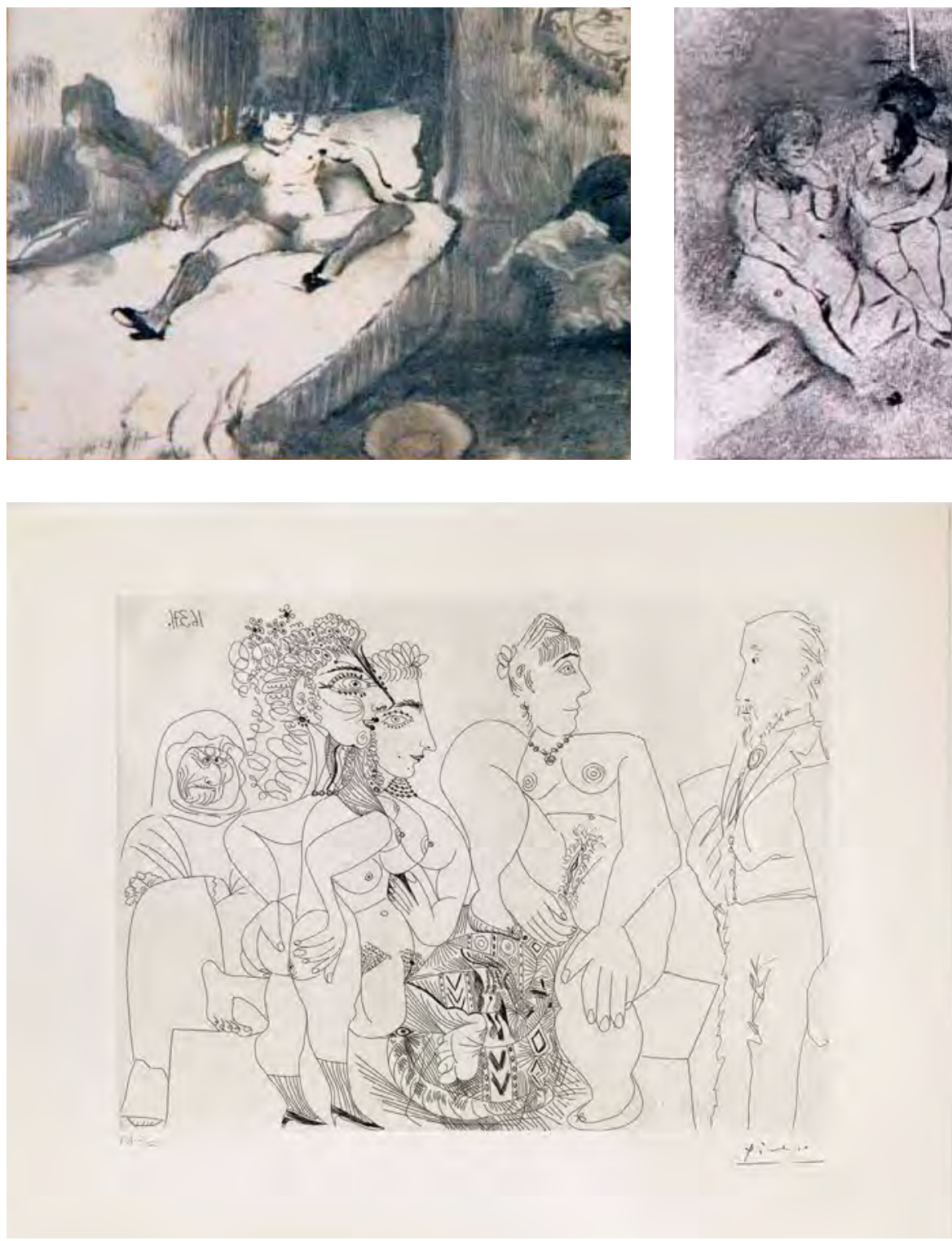

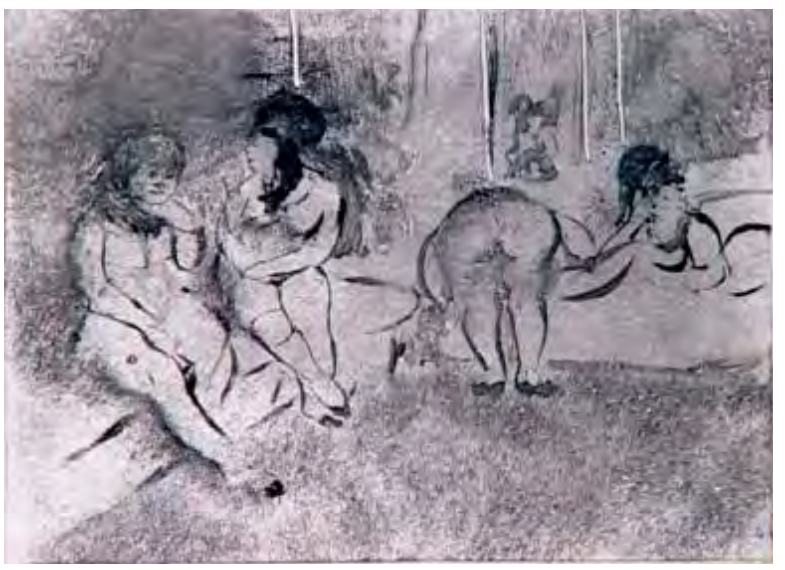

86 Edgar Degas

Repouso sobre a cama, 1879 Monotipia

$16,4 \times 21,5 \mathrm{~cm}$

Museé Picasso, Paris

87 Edgar Degas

Espera, 1879

Monotipia

$16,4 \times 21,5 \mathrm{~cm}$

Museé Picasso, Paris

88 Pablo Picasso

Bordel. Degas com seu álbum, cafetina e puff marroquino 16 de março de 1971

$50,2 \times 65 \mathrm{~cm}$ 

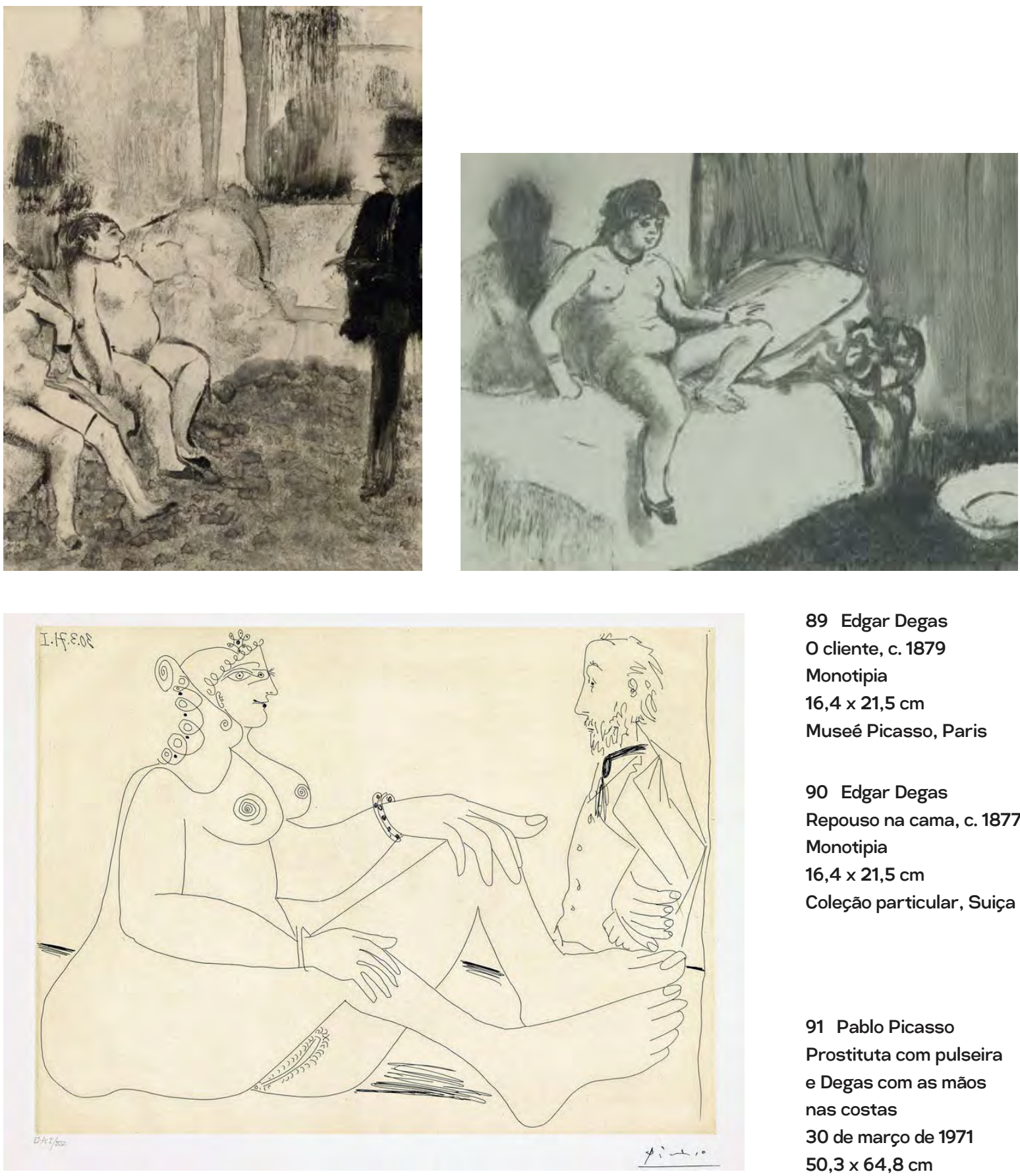

89 Edgar Degas

O cliente, c. 1879

Monotipia

$16,4 \times 21,5 \mathrm{~cm}$

Museé Picasso, Paris

90 Edgar Degas

Repouso na cama, c. 1877

Monotipia

$16,4 \times 21,5 \mathrm{~cm}$

Coleção particular, Suiça

91 Pablo Picasso

Prostituta com pulseira e Degas com as mãos nas costas

30 de março de 1971 $50,3 \times 64,8 \mathrm{~cm}$ 
em um acontecimento único. Esfumaçam-se as distinções entre atividade e passividade: quem é mais ativo? A mulher a exibir seus genitais ou nós a abservá-la?

Steinberg (que outrora defendera que o artista era uma espécie de "argovoyeur cujos olhos enxergam a partir de mil pontos") acreditava que o diagnóstico de "voyeurismo, quase sempre aplicado levianamente ao velho Picasso, parece simpesmente incorreto ${ }^{368 "}$ em se tratando dessas imagens. Para o autor, "Picasso não está espiando, não está espreitando buracos de fechaduras, mas sim trazendo à tona recintos interiores" ${ }^{369}$.

Essa afirmação me parece (como de costume) correta e pontiaguda, mas, ao mesmo tempo, imprecisa. Não porque as fizgigs de Picasso sejam projeções de um vetusto voyeurista, mas porque são a forma mais apurada de expurgar a prerrogativa da visão ao observador, encarcerando-lhe nesse único pressuposto. No entanto, não é como se elas estivessem alheias ao modo como Picasso incorpora toda a tradição figurativa (e voyeurista) da arte ocidental: as fizgigs são como as mulheres das gravuras da Suite 156 em sua forma isolada, figuras que prescindiram de tudo que as rodeia para que pudessem manter uma relação ainda mais estreita com aquele que as vê - nesse caso, o próprio observador das gravuras. É impossível esquivar-se do que está frontalmente exposto: as vaginas são o ponto mais denso da composição e tudo ao redor delas se esmingua. Não há possibilidade de rodear o corpo feminino, ou de remeter o olhar a uma testemunha no interior das imagens, como era o caso de Degas. Há um voyeurismo compulsório, direcionado sem rodeios ao observador.

Nesse sentido - e somente nesse sentido - essas mulheres (fig 96.) remetem ao manequin estirado de Étant Donnés, de Marcel Duchamp (fig. 95). Frente a elas, não há escapatória: suas vaginas arreganhadas são, simultaneamente, o ponto final e o ponto de fuga para a projeção do observador.

368 Ibid., p. 32.

369 Idem. 

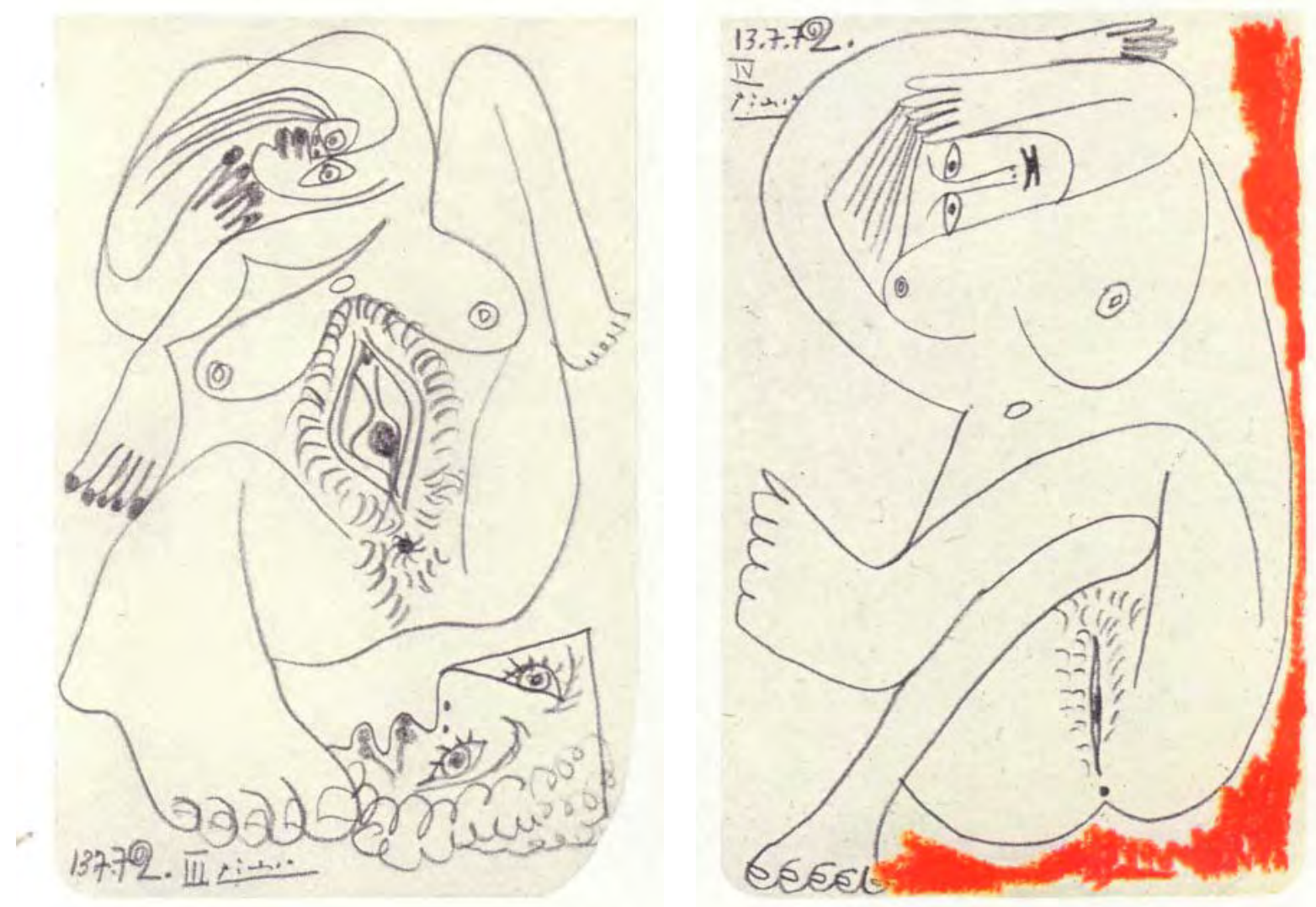

92 Pablo Picasso

Nu reclinado

13 de julho de 1972

Lápis sobre papel

Coleção particular



93 Pablo Picasso

Nu reclinado

13 de julho de 1972

Lápis e giz de cera sobre papel

Coleção particular

94 Pablo Picasso

Nu reclinado

14 de julho de 1972

Lápis sobre papel

Coleção particular 

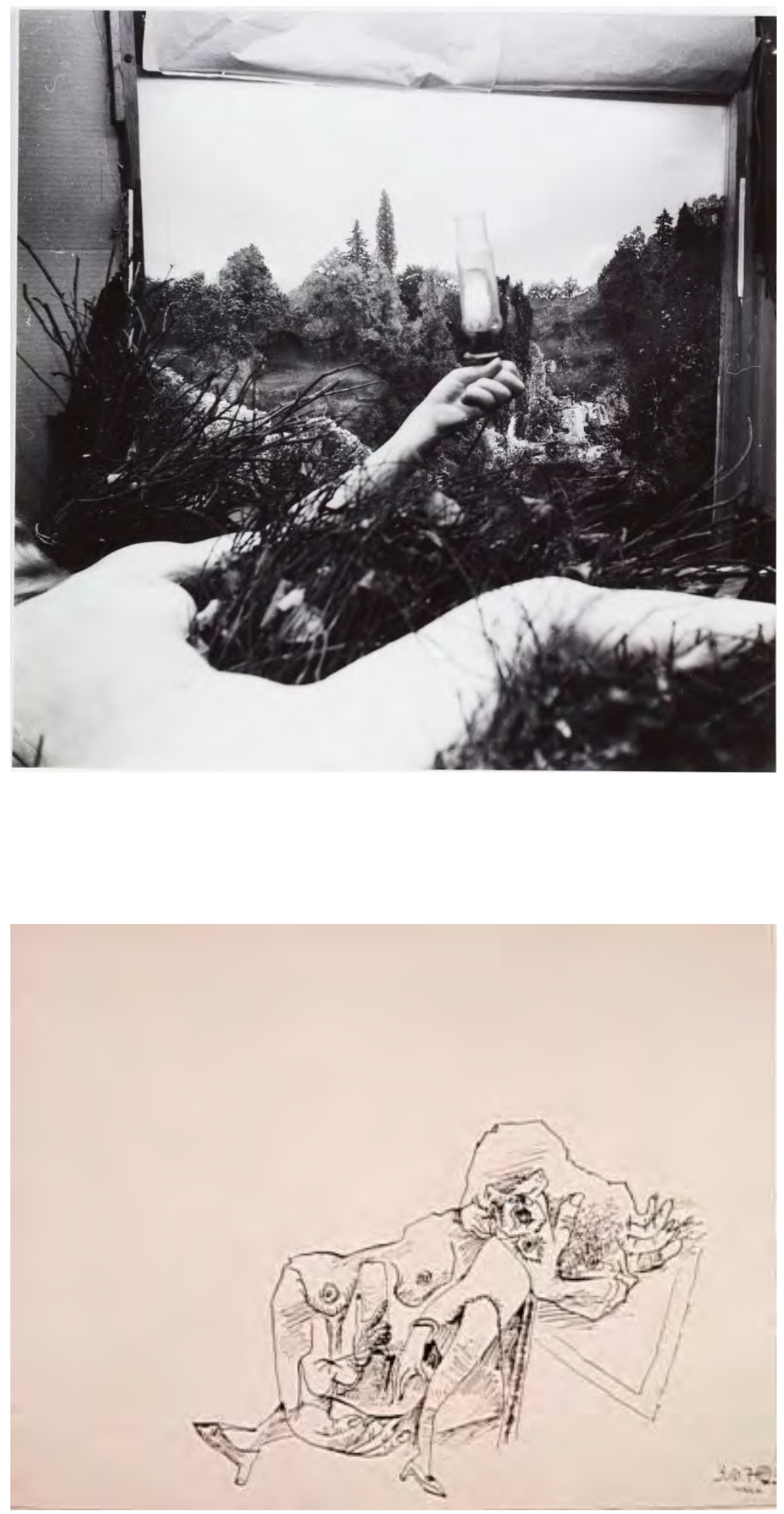

95 Fotografia de Étant donnés no Estúdio da 11th Street, por Denise Brown, 1968 Museu de Arte da Filadélfia, Arquivos, Anne d'Harnoncourt Records.
96 Pablo Picasso

Nu reclinado

03 de outubro de 1972

Bico de pena e nanquim sobre papel $59,3 \times 76,2 \mathrm{~cm}$

Musée Picasso Paris 



\section{Considerações Finais}

Quarenta e cinco anos se passaram desde a morte de Picasso (e cinquenta, desde a de Duchamp) e não deixa de ser curioso que os últimos trabalhos deixados para a posterioridade por ambos - dois dos mais prestigiados artistas do século $\mathrm{XX}$-expõem a vagina da mulher e o olhar do observador (masculino) de modo tão peremptório. Os caminhos percorridos até chegar lá (bem como os resultados alcançados) são radicalmente distintos, evidentemente, e espero que isso tenha ficado claro ao longo dessa dissertação. A coincidência, entretanto, não deixa de ser instigante.

Ao longo dessas mais de quatro décadas, muitas mudanças que já estavam em curso se acirraram e muitas outras inimagináveis tiveram lugar - e com isso, a própria forma com que olhamos para os trabalhos também se transformou. Ao examinar a recepção de Étant Donnés, busquei demonstrar como a discussão sobre a obra se renovou no transcorrer dos anos. Nesse percurso, compreendemos como a obra, sobretudo na visão de autoras feministas, pôde ser interpretada como uma espécie de literalização das premissas por trás da visualidade na cultura figurativa e da tradição perspectiva, que as expõe e as torna visíveis. Parece-me que essa leitura, como sinalizei anteriormente, encontra na literalidade da obra o espelhamento de seus próprios objetivos e métodos: ela valoriza a obra por acreditar em sua capacidade de revelar preceitos ideológicos que subsistem em formas dominantes do pensamento e do discurso na sociedade ocidental. A brutal exposição do corpo feminino e o voyeurismo explícito e deliberadamente estimulado pode ser aceito, desde que a serviço de uma atitude "crítica", no sentido mais corrente do termo hoje. 
E as gravuras de Picasso, nas quais a exposição dos genitais femininos é igualmente ostensiva? Como interpretá-las? Nesse caso, autoras e autores cujo pensamento se alinha com uma vertente feminista da crítica de arte não se mostraram inclinados, em um primeiro momento, a aceitar a exibição do corpo com bons olhos. Essas estampas com seu arsenal de referências à tradição, ao passado, enfim - lhes pareciam fantasias fetichizadas de um impúdico e impotente voyeurista, siderado por lembranças de mais de nove décadas vividas. De certo modo, elas lhes pareceram antes o efeito da episteme modernista do que um comentário sobre ela.

De fato, em muitas dessas imagens, flerta-se com a exposição do corpo feminino, na mesma medida em que se bufoneia do observador que se satisfaz com tal exibição. Mas e quanto a essa atitude? Ela é satírica? Irônica? Ou trata-se de humor? Podemos, enfim, interpretar essas gravuras como paródia? E se sim, não seriam elas, portanto, também escólios inusitados de toda a tradição figurativa, e não somente páginas de um diário de memórias impolutas? E o que dizer a respeito do fato de que as convenções da história da arte são, nessas imagens, frequentemente justapostas a uma linguagem que parece derivar da pornografia? Trataria de uma transgressão autorizada, cuja ambivalência brota dos impulsos duais de forças radicais e conservadoras?

Estas são algumas das indagações que permanecem no ar, após todo o esforço por empreender uma reflexão sobre essas imagens. Uma das impressões que tenho é que estamos menos dispostos aceitá-las, entre outras coisas, por sua atitude ao mesmo tempo reverencial e mordaz com respeito a todo o legado da tradição figurativa. Seus objetivos e métodos dificilmente corresponderiam àquilo que hoje entendemos como "crítica", de um ponto de vista hermenêutico, pois o que rege sua conduta em relação às obras, discursos, convenções e linguagem é um desígnio ambivalente, a um só tempo afetivo e insubordinado.

Se assim for, suspeito que a rejeição à ambiguidade e a decorrente valorização da assertividade seja uma estratégia, no mínimo, temerária. O perigo reside, nos casos extremos, em atrelar nossa compreensão da arte e dos processos estéticos a um valor educativo - a um ensinamento didático que cerceia as possibilidades de expressão e de entendimento do fazer artístico. E, particularmente, prefiro crer que os ensinamentos da arte não são exatamente iguais aos da sala de aula. 
Pouco tempo atrás, eu estava escutando um podcast (hoje, não ouvimos mais transmissões radiofônicas, selecionamos todo o conteúdo que consumimos) a respeito de artistas que resolveram reescrever suas obras passadas em nome de anseios do presente. Não se trata de um caso isolado: muitos são aqueles que andam revisando trabalhos de autoria própria ou mesmo de autoria alheia, apagando ou modificando representações racistas e machistas de músicas e filmes como um modo de reparação histórica ou de auto-crítica.

Levanto essa questão porque suponho que esse tipo de atitude revisionista deriva, em grande medida, de uma exigência (que se fortaleceu de alguns anos para cá) de que os métodos e objetivos de determinada obra de arte - vista como representação - e do pensamento crítico andem de mãos atadas ${ }^{370}$. Essa atitude é movida por uma convicção ética que jamais poderemos esperar do finado Picasso caso prezemos por nos esquivar de um sistema de dois pesos e duas medidas. De todo modo, será justo exercer uma pressão social sobre a cultura para, assim, impedir que os preconceitos se perpetuem? Em caso positivo, qual é o lugar da obra de arte numa cultura política eternamente afirmativa?

Não tenho a menor intenção, evidentemente, de esbravejar contra as reivindicações identitárias, que talvez sejam, hoje, as que com mais força hasteiam as bandeiras de um pensamento renovado. O barril de pólvora já é munição exclusiva daqueles que, em nosso tempo, lamentavelmente disparam contra o que eles mesmos definem como "politicamente correto" desde os palanques e as fortalezas do poder. Acredito, não obstante, que rejeitar e expurgar as obras de arte que - seja no passado, seja no presente - não correspondem fielmente a nossos objetivos e expectativas não as torna alheias a nós mesmos e à nossa história. De resto, é contraproducente insistir no fato de que atacar os sintomas não elimina as causas reais de qualquer padecimento - quando muito as oblitera. Representações não são sintomas, poderia-se contrargumentar, mas são parte de um sistema que estrutura toda nossa forma de pensar. Ainda assim, prefiro acreditar (por mais idealista que pareça) que cabe à nossa sociedade cultivar no espectador as ferramentas críticas ao vocabulário, às formas e às imagens de uma obra de arte, ao invés de exigir do próprio trabalho que adeque sua linguagem a tais ferramentas.

370 Ainda que por vias distintas, tendo a corroborar com o pensamento de Hal Foster, que discutirá como a "virada semiótica" (que remodelou muito da arte e da crítica a partir do modelo do texto na segunda metade dos anos 1970) fez com que a criticalidade da teoria contemporânea se transformasse num estratagema de posicionamento para a arte. Para essa discussão, veja-se os capítulos 1 e 7 de FOSTER, Hal. O Retorno do Real, op. cit. 
É claro que, independentemente de tudo isso, o nome de Picasso jamais será apagado das linhas da história - afinal, ele é, muitas vezes, identificado (e mesmo confundido) com o próprio modernismo. Entretanto, não é difícil perceber que minha geração não é exatamente afeita à obra do artista. Digo isso por experiência própria: quase sempre, ao comentar que minha dissertação de mestrado consistia em refletir sobre seu trabalho, recebia como resposta rostos constrangidos e uma série de interrogações contestatórias. Nada espantoso, evidentemente, consideradas as circunstâncias. Pois crescemos e nos formamos sabendo que mesmo Hal Foster, um crítico experiente (veterano, em relação às gerações mais jovens), cuja atuação e pensamento contundentes muitos de nós admiramos, admitira que ele e os críticos formados em seu meio, à diferença de seus predecessores, confrontavam-se com "Marcel Duchamp por meio de Andy Warhol, mais do que Picasso por meio de Pollock"371.

Não que a distância ou mesmo as animosidades e os desafetos sejam um termômetro preciso para decretar óbito a um trabalho de arte. Quando muito, elas aferem a temperatura de um semblante combalido. Parece-me difícil, hoje, defender que a obra de Picasso esteja a léguas de distância das questões centrais da arte e da cultura contemporânea. Em uma resenha realizada na ocasião da exposição Picasso Érotique em Montreal, o crítico e historiador da arte Robert Silberman sintetizou muito do que procurei traçar nessa dissertação. Após constatar que, se tivermos como parâmetro o trabalho de artistas como Robert Mapplethorpe ou Jeff Koons, o erotismo de Picasso aparenta ser quase antiquado [old-fashioned], pondera:

Ainda assim, o fascínio de Picasso pelo voyeurismo e pelo olhar, sua consciência de como o poder e a violência informam a repetição sexual, sua implacável preocupação com o corpo, suas complicadas formas de auto-representação e seu senso de humor ajudam a torná-lo contemporâneo. ${ }^{372}$

371 Ibid., p. 12.

372 SILBERMAN, Robert. "Picasso érotique. Paris, Montreal and Barcelona", in The Burlington Magazine, Vol. 143, No. 1184 (Nov., 2001), pp. 716. Traduzido livremente, do original: "Yet Picasso's fascination with voyeurism and the gaze, his awareness of how power and violence inform sexual replaying, his relentless concern with the body, his complicated self-representation, and his sense of humor, all help to make him seen contemporary.". 
O ponto, evidentemente, não é parecer ou não atual, embora o pertencimento à atualidade não possa afastar-se em demasia do radar quando os objetivos são examinar, em retrospecto, uma obra do peso e da estatura da de Picasso. O que busquei, ao longo dessa dissertação, foi debruçar-me sobre a obra, em vista da posição emblemática que ela ocupa no debate contemporâneo. Por isso mesmo, decidi partir de Las Meninas: nesse momento, já se colocavam em pauta a volta de Picasso aos "grandes mestres", o tom humorado e o voyeurismo em sua obra. Não à toa, essa série é um dos marcos de declínio estabelecidos por John Berger em sua crítica à trajetória do artista ${ }^{373}$. Espero, de todo modo, ter dado a devida atenção analítica às pinturas, sem reduzi-las às discussões mais ou menos enviesadas que poderiam derivar desse debate.

Cumpre reconhecer que o esforço por repor a obra de Picasso na agenda contemporânea não é de hoje, e talvez tenha sido empreendido desde que a morte retirou do artista a condição de um grande nome vivo. Ainda assim, os termos que pautam essa reposição se mantêm, em larga medida, os mesmos.

Alguns anos atrás, em 20I4, quando Picasso já havia deixado há muito de ser o foco da atenção do mundo da arte, a mesma motivação de repaginar sua importância deu fruto à exposição "Post-Picasso: Contemporary Reactions", organizada pelo curador e professor de história da arte do Trinity's College, Michael C. Fitzgerald. Nela, buscou-se mapear a recepção contemporânea da obra de Picasso ao redor do mundo. A exposição, como o próprio curador admitiu, recebeu considerável atenção midiática: se, por um lado, a resposta à mostra se deu majoritariamente em chave positiva, um grande número de curadores e críticos ligados à arte contemporânea esboçou reações de indignação a respeito da proposta curatorial, questionando os motivos que justificariam uma grande exposição dedicada à importância histórica de Picasso. A obra do artista, segundo eles, tornara-se irrelevante no contexto da produção atual, e seu legado, confinado ao impacto que exercera à arte moderna.

373 Ao estabelecer Las Meninas e a volta a obras de antigos mestres como marco do desespero de Picasso, Berger dirá: "But what is certain is that neither Picasso's Las Meninas nor any of his late paintings are the mature work of an old painter, at last able to be himself. What is certain is that Picasso is a startling exception to the rule about old painters." Cf. BERGER, op. cit., p. 390. 
O que talvez tenha passado inadvertido a muitas dessas críticas é que sua avaliação não era alheia a evidências contundentes no seio da própria exposição, cujo recorte curatorial reforçava também o status de contra-modelo que a obra de Picasso veio adquirir para a produção contemporânea. Não por acaso, o subtítulo da mostra emprega tanto a palavra "reações" quanto a palavra "Picasso", incorporando o nome que pretende suplantar sem por isso deixar de demarcar uma posição renitente frente a ele. Será esse o compasso que seguirá normatizando a cadência de nossa interpretação da obra de Picasso? 



\section{Referência bibliográficas}

\section{Sobre Picasso e Arte Moderna}

ANGLIN-BURGARD, Timothy, "Picasso and Appropriation", in The Art Bulletin 72, n. 3, I99I

APOLLINAIRE, Guillaume. The Cubist Painters: aesthetic meditations, I9I3. Nova York: Wittenborn, Schultz, 1949.

APOLLINAIRE, Guillaume. Apollinaire on art: Essays and Reviews; I90I-I9I8. Nova York: Viking, 1972.

ARNHEIR, Rudolf. Guernica de Picasso. Barcelona : Gustavo Gili, 1976.

BALDESSARI, Anne; COWLING, Elizabeth; ELDERFIELD, John; GOLDING, John; MONOD-FONTAINE, Isabelle; VARNEDOE, Kirk. Matisse and Picasso. Londres: Tate Modern; Paris: Musée National d'Art Moderne; Nova York: The Museum of Modern Art, 2002.
BARAÑANO, Kosme de. "La Suite I56 de Pablo Picasso como Screenplay y Script.", in Picasso: Cine y Arte. Málaga: Fundación Picasso Museo Casa Natal, 201 I.

BARR JR, Alfred H. Picasso: Fifty years of his Art. Nova York: Museum of Modern Art, I946.

BARR-SHARRAR, Beryl. "Some Aspects of Early Autobiographical Imagery in Picasso's Suite 347", in: The Art Bulletin, Vol. 54, No. 4 (Dec., I972), pp. 516-533.

BERGER, John. The Success and Failure of Picasso. Nova Iorque: Pantheon Books,I980.

BERGER, John. “An Old Man's Frenzy”, Art International, 3, Verão de 1988.

BOIS, Yve-Alain. Matisse e Picasso. São Paulo: Melhoramentos, 2000.

BOIS, Yve-Alain. Painting as Model.

Cambridge: MIT Press, 1990. 
BOIS, Yve-Alain (org.). Picasso's Harlequin, I9I7-I937. Milão : Skira, 2009

BRASSAÏ. Conversas com Picasso. São Paulo: Cosac Naify, 2000.

BRITO, Ronaldo. "Picasso", Experiência Crítica. São Paulo: Cosac Naify, 2005. p. 25-28.

BROUDE, Norma. Picasso, Artist of the Century (Late Nineeteenth). Arts, outubro de I980, pp. 84 a 86

BLUNT, Anthony. Picasso's Guernica. Nova York: Oxford University Press, 1969.

BUCHLOH, Benjamin. Figures of Authority, Ciphers of Regression: Notes on The

Return of Representation in European Painting, em October, no I6, primavera de I98I, p. 39-68.

COCTEAU, Jean. Entre Picasso et Radiguet. Paris: Hermann, 1967.

CABANNE, Pierre. Pablo Picasso, His Life and Times. Nova York: Morrow, I977.

CABANNE, Pierre. Le siècle de Picasso. Paris : Denoël, I975.

CHIPP, Herschel B. Picasso's Guernica : history, transformations, meanings. Londres: Thames and Hudson, 1989.

CHRISTENSON, C. V. (org). Studies in Erotic Art. Nova York: Basic Books, I970.

CLAIRE, Jean. Une leçon d'abîme : neuf approches de Picasso. Paris : Gallimard, 2005.

CLARK, T. J. "Hight-Step with a Bull". In: London Review of Books, vol. 34, no.15, 2 de agosto de 2OI 2, p. I4-I5.
CLARK, T.J. Farwell to an Idea: Episodes From a History of Modernism. Londres/New Haven: Yale University Press, I999[ed. Rev. 200I].

CLARK, T. J. Cubism and Collectivity, in Farwell to an Idea: Episodes from a History of Modernism. New Haven and London: Yale University Press, I999, pp.I69-224.

CLARK, T. J. Picasso and truth: From Cubism to Guernica. Princeton: Princeton University Press, 2013.

CLARK, T. J. "False Moderacy". In: London Review of Books, vol. 34, no. 6, 22 de março de 2OI2, p. II-I3.

COMBALÍA, Victoria. Picasso y Miró: Miradas Cruzadas. Madrid: Electa, 1998.

COOPER, Douglas. Picasso, Theatre. Nova York: Abrams, 1987.

COOPER, Douglas David. Pablo Picasso: Les Déjeneurs. Paris: Éditions Cercle d'Art, 1962

COTTINGTON, David. Cubismo. São Paulo: Cosac Naify, 1999.

COTTINGTON, David. "What the Paper Says: Politics and Indeology in Picasso's Collages of I9I2". em Art Journal, vol. 47, no. 4, Revising Cubism, inverno de I988, p. 350-359.

COWLING, Elizabeth. Picasso: Style and Meaning. Nova York: Phaidon, 2002

COWLING, Elisabeth. Picasso, Léger, De Chirico and The New Classicism, I9IO-I930. Londres: Tate Gallery Publications, I990.

COWLING, Elisabeth. Visiting Picasso: Notebooks and Letters. London: Thames and Hudson, 2006 
COWLING, Elisabeth; KENDALL, Richard. Picasso Looks at Degas. Williamstown: Sterling and Francine Clark Art Institute, Museo Picasso, 2010.

CHAVE, Anna C. "New Encounters with Les Demoiselles d'Avignon: Gender, Race and the Origins of Cubism". Art Bulletin, no. 4, Dezembro de I996, pp. 596-6II.

DAIX, Pierre. Picasso: Life and Art. Londres: Thames and Hudson, I994.

DAIX, Pierre; ROSSELET, Joan. Picasso: The Cubist Years: 1907-1916. Londres: Thames and Hudson, 1979.

DAIX, Pierre. La Celestine e ses retours dans l'ouevre de Picasso. Paris: Didi Imbert, I988, p. 33-34.

DANTO, Arthur Coleman. Unnatural wonders: essays from the gap between art and life. Nova York: Farrar, Straus, Giroux, 2005.

DIEHL, Gaston. Picasso. Nova York : Crown Publishers, 1960.

D’ORS, Eugeni. Picasso en tres revisiones. Madri: Aguilar, 1946.

EGRI, Peter. "A Portrait of the Artist as a Caricaturist: Picasso, Joyce, Britten", Comparative Literature Studies, Vol. I9, No. 2, James Joyce and His Contemporaries (Sumfmer, 1982), pp. 97-I2O.

ELUARD, Paul. Pablo Picasso. Londres: M. Secker and Warburg, cI947.

FRASCINA, Francis, HARRISON, Charles, PERRY, Gill. Primitivism, Cubism andAbstraction: The early Twentieth-Century. New Haven: Yale University Press, 1993.

FAGUNDES JR., Carlos E. Uchoa. O beijo da história : Picasso como emblema da contemporaneidade. São Paulo : Editora 34, 1996.
FERRIER, Jean Louis. Picasso, guernica : anatomie d'un chef-d'oeuvre. Paris: Denoël, 1977.

FLORMAN, Lisa. Myth and Metamorphosis: Picasso's Classical Prints of the I930s. Cambridge; Londres: MIT Press, 2000.

FLORMAN, Lisa. "The Difference Experience Makes in 'The Philosophical Brothel'”. In: The Art Bulletin, vol. 85, no 4, dezembro de 2003, p. 769-783.

FLORMAN, Lisa. "The Flattening of 'Collage'. In: October, IO2, outono de 2002, p. 59-86.

FRY, Edward F. Picasso, Cubism and Reflexivity. In: Art Journal, vol. 47, no 4, inverno I988, p. 296-310.

FOSTER, Hal. "The Primitive Unconscious of Modern Art”. In: October, no. 34, 1985, pp. 45-70.

FOSTER, Hal. O retorno do real, trad. Célia Euvaldo, São Paulo: Ubu, 2017.

GILOT, Françoise; LAKE, Carlton. Vivre avec Picasso, Paris: Calmann-Lévy, 1965

GILOT, Françoise . Matisse e Picasso. São Paulo: Siciliano, I992.

GLEIZES, A. e METZINGER, J. Cubism. Londres: Fisher Unwin, I9I3.

GOLDING, John e PENROSE, Roland. Picasso in Retrospect. Nova York: Harper and Row, 1980.

GEDO, Mary Matthews. "Art as Exorcism: Picasso's Demoiselles d'Avignon”. In: Arts Magazine 55, no. 2, outubro de I980, pp. $70-83$.

GEDO, Mary Mathews. Picasso: Art as na Autobiography. Chicago: University of Chicago Press, I980 
GOPNIK, Adam. "High and Low: Caricature, Primitivism and Cubist Portrait". In: Art Journal, 43, no. 4, inverno 1983, pp. 37I-376.

GREEN, Christopher (org). Picasso's Les Demoiselles d'Avignon. Cambridge: Cambridge University Press, $200 I$.

GREEN, Christopher. Picasso, Architecture and Vertigo. New Haven e Londres: Yale University Press, 2005.

HOLLOWAY, Memory. "Inside the Sultan's Palace: Picasso and Television", em Making Time: Picasso's Suite 347. Nova Iorque: Peter Lang Publisher, American university studies XX. Fine arts, vol. 35 .

HUTTON TURNER, Elisabeth. "Who Is in the Brothel of Avignon? A Case for Context". In: Artibus et Historiae, Vol. 5, No. 9 (1984), pp. I39-I57.

JOHNSON, Ron. "Les Demoiselles d'Avignon and Dionisyan Destruction". In: Arts Magazine 55, no. 2, outubro I980, pps, 94-IOI.

HOFFMAN, Katherine (ed.). Collage: Critical Views. Ann Arbor, Michigan: U.M.I. Press, I989.

KAHNWEILER, Daniel-Henry. Minhas galerias e meus pintores. São Paulo: L\&PM Editores, 1992.

KAHNWEILLER, Daniel-Henry. "Entretiens avec Picasso", Quadrum, n. 2, nov. 1956, p. 74.

KARMEL, Pepe. Picasso and the Invention of Cubism. Yale University Press, 2003.

KLEINFELDER, Karen K. The Artist, his model, her image, his gaze: Picasso's pursuit of the model. Chicago: The University of Chicago Press, I993
KRAUSS, Rosalind. Os papéis de Picasso. São Paulo: Iluminuras, 2006.

KRAUSS, Rosalind. The Originality of the Avant-gard and Other Modernist Myths. Cambridge: MIT Press, I985.

KRAUSS, Rosalind. The Optical Uncounciouss. Cambridge and Massachusetss: MIT Press, I993.

KRAUSS, Rosalind. "In The Name of Picasso", in October, Vol. I6, Art World Follies (Spring, I98I), pp. 5-22.

LILIANA ANTACLI, Paulinia. "La fórmula de pathos de la Ninfa según Aby Warburg: Un estudio sobre la supervivencia del modelo mítico femenino en un corpus de la obra de Pablo Picasso." Tese de apresentada à Universidade Nacional de Córdoba para obtenção do título de doutor em artes, 2015.

LEIGHTEN, Patricia. Re-ordering the Universe; Picasso and Anarchism, I897-I9I4. Princeton: Princeton University Press, 1989.

LEIGHTEN, Patricia. "The white Péril and L'Art Nègre: Picasso, Primitivism and Anticolonialism". In: The Art Bulletin 72, no 4, dezembro de I990, pp.609-30.

LEJA, Michael. "Le Vieux Marcheur' and 'Les Deux Risques': Picasso, Prostitution, Venereal Disease, and Maternity, I899-I907", Art History, Março de I985, pp. 66-8I.

MADELINE, Laurence (org.). Picasso TV. Málaga: Fundación Museo Picasso Málaga, 2014 .

MELIUS, Jeremy. "Inscription and Castration in Picasso's The Painter and His Model, I927", In: October I5I, Inverno 20I5, pp. 43-6I. 
McCULLY, Marilyn (ed.). A Picasso Anthology: Documents, Criticism, Reminiscences. Londres: Arts Council of Great Britain/ Thames and Hudson, I98I.

PARMELIN, Helène. Voyage en Picasso. Paris: Robert Lafont, 1980.

PALAU I FABRE, Josep. Picasso, The Early Years I88I-I907. Nova York e Londres, I98I.

PALAU I FABRE, Josep. Picasso vivo. Madrid: Poligrafía, I980.

PENROSE, Roland. The Sculpture of Picasso. Nova York: The Museum of Modern Art,1967.

PENROSE, Roland: Picasso, Flammarion, Paris, 1982

PICASSO Special Issue, Art in America, dezembro I980, no IO.

POGGI, Christine. In Defiance of Painting: Cubism, Futurism, and the Invention of

Collage. New Haven: Yale University Press, 1992.

RAMÍREZ Juan Antonio. Picasso : el mirón y la duplicidad. Madri: Alianza Editorial, 1994.

RICHARDSON, John. "L'epoque de Jacqueline”, Le Dernier Picasso, 1953-I973, Paris: Centre George Pompidou, 1988, pp. 53-77

RICHARDSON, John. A life of Picasso, Volume I, I88I-I906. Nova Iorque: Random House, I99I.

RICHARDSON, John. A Life of Picasso, Volume II, I907-I9I7. Nova Iorque: Alfred A. Knoft, 2003.

RICHARDSON, John. Picasso The Triumphant Years, Volume III, I9I7-I932. Nova Iorque: Alfred A. Knoft, 2007.
RICHARDSON, John. The Sorcerer's Apprentice: Picasso, Provence, and Douglas Cooper. Nova Iorque: Alfred A. Knoft, I999.

RICHARDSON, John. Sacred Monsters, Sacred Masters: Beaton, Capote, Dalí, Picasso, Freud, Warhol, and More. Nova Iorque: Alfred A. Knoft, 2002.

ROSENBLUM, Robert. "Picasso and the Anatomy of Eroticism". In: BOWIE, Theodore; CHRISTENSON, Cornelia V. (ed.). Studies in Erotic Art. Nova York: Basic Books Publishers, I970, p. 337-350.

RUBIN, William. Picasso in the Museum of Modern Art. Nova Iorque: The Museum of Modern Art, 1980.

RUBIN, William. Picasso and Braque: Pioneering Cubism. Nova York: Museum of Modern Art, I989.

RUBIN, William (org.). Picasso and Portraiture. Thames \& Hudson, 1996.

RUBIN, William (ed). Les Demoiselles d'Avignon: Studies in Modern Art. Nova York: Museu de Arte Moderna, I984.

RUBIN, William."Visits with Picasso at Mougins", Art News 27, no. 6, Verão de 1973.

SCHAPIRO, Meyer. A unidade da arte de Picasso. São Paulo: Cosac Naify, 2002.

SALZSTEIN, Sônia. "Uma pintura de interiores", em Matisse: imaginação, erotismo e visão decorativa. São Paulo: Cosac Naify, 2009.

SABARTES, Jaime. Picasso: Documents iconographiques. Geneva: Pierre Cailler, I954.

SCHIFF, Gert (ed.). Picasso in Perspective. Nova Jersey: Prentice Hall, 1976. 
SCHIFF, Gert. "Picasso's Old Age: I963-I973", in Art Journal, Vol. 46, No. 2, Old-Age Style

(Summer, 1987)

SPIES, Werner. Sculpture by Picasso. Nova York: Abrams, I97I.

STEIN, Gertrude. Picasso. New York : Dover, I984.

STEINBERG, Leo. Outros Critérios. São Paulo: Cosac Naify, 2008.

STEINBERG, Leo . "The Philosophical Brothel". In Art News, set.-out. 1972.

STEINBERG, Leo . "A Working Equation or - Picasso in the Homestretch". In The Print Collector's Newsletter, n. 3, nov.-dez. 1972.

STEINBERG, Leo . "Resisting Cezanne: Picasso's Three Women." In: Art in America, 66 (November 1978), p. II4-33.

STEINBERG, Leo. "Fim de partida de Picasso", em ARS, n. 9, 2007. p. 25-35.

SYLVESTER, David. "End Game”, in Late Picasso, Londres: The Tate Gallery, I988, p. I37.

UTLEY, Gertje. Picasso: the Communist Years, New Haven: Yale University Press, 2000.

WOLLHEIN, Richard. "Pintura, Textualidade e Apropriações", in A pintura como modelo, São Paulo: Cosac e Naify, I992, pp. I87-248.

ZERVOS, Christian. Pablo Picasso, Catalogue raisonné, 33 volumes. Paris: Cercle d'Art, I932-I978.

ZELEVANSKY, Lynn (org.). Picasso and Braque: A Symposium. Nova York: Museum of Modern Art, 1992.
Sobre Las Meninas de Picasso

ANDERSON, John. "Faustus/Velázquez / Picasso", in Picasso in Perspective, Gert Schiff (org.), New Jersey: Prentice-Hall, I976, p. I6I.

ALAMINOS, Eduardo. "Picasso en el espacio de Las Meninas". In: Batik, no. 64, nov.-dec. I98I, p. 29-33

BERNADAC, Marie-Laure. "Picasso Cannibale. Desconstruction-Reconstruction des Mâitres, em Picasso et les Mâitres, Anne Baldessari e Marie-Laure Bernardac (orgs.). Paris: Éditions de la Réunion des Musées Nationaux, 2008.

CAMÓN AZNAR, José. "Velázquez por Picasso". Miscellanea Barcinonensia, Any VII, jull. I968, núm. XIX, p. 33-35

AZNAR, José Camón. "Las Meninas de Velázquez, según Picasso". In: Revista Goya, FLG, núm. 86, septiembre-octubre 1986.

CALVO-SERRALLER, Francisco. Picasso Tradición y Vanguardia. Madrid: Museo del Prado, 2006.

CIRLOT, Laporta, Juan-Eduardo. "El informalismo de Las Meninas de Picasso". In: Revista de Actualidades, artes y letras. Año VII, no. 374 (I3 de junio de I959), p. I6, 23

GALASSI, Susan Grace. Picasso's Variations on the Masters. Nova Iorque: Harry Abrams Puclisher, 1996.

GALASSI, Susan Grace. "Picasso in the Studio of Velázquez", in Picasso and the Spanish Tradition, Jonathan Brown (ed.), New Haven e Londres: Yale University Press, 1996.

ESTEBAN, Paloma (ed.); Picasso: las grandes series [cat. expo.]. Madrid, Aldeasa/Museo Nacional Centro de Arte Reina Sofía, 200I. 
KLEINFELDER, Karen K. The Artist, his model, her image, his gaze: Picasso's pursuit of the model. Chicago: The University of Chicago Press, 1993, pps. 57-67

LEIRIS, Michel. "Picasso et les Ménines de Velasquez". In: Un génie sans piédestal et autres écrits sur Picasso. Paris: Fourbis Direct, $201 \mathrm{I}$.

OCAÑA, Maria Teresa. "La violación de Las meninas", em Picasso, Las Grandes Series. Madrid: Museo Nacional Centro de Arte Reina Sofía (MNCARS); Aldeasa, 200I, pp. I37-I57.

PALAU I FABRE, Josep; El secret de les Menines de Picasso. Barcelona, Polígrafa, 1982.

RAFART i PLANAS, Claustre. Las Meninas de Picasso, Barcelona: Meteora, 200I, p. 27.

Museu Picasso, catálogo de pintura y dibujo. Barcelona, Ajuntament de Barcelona. Museu Picasso, 1985 .

SABARTÉS, Jaime. Picasso: Las Meninas y la Vida. Barcelona, Ediciones Poligrafa, 1969, p. I9

UTLEY, Gertje J., "Las Meninas in Twentieth-Century Art”, em Velázquez's Las Meninas, ed. Sazanne Stratton-Pruitt. Cambridge: Cambridge University Press, 2003, pps. I7 I-2O2

UTLEY, Gert; GUAL, Malén (org.). Olvidando a Velázquez Las Meninas. Barcelona: Institut de Cultura / Museu Picasso de Barcelona: 2008.
Sobre Las Meninas de Velázquez

ALPERS, Svetlana. "Interpretation without Representation, or the viewing of Las Meninas", Representations, i, I (1983), pps. 34-46.

ALPERS, Svetlana. "Describe or Narrate? A Problem in Realistic Representation", New Literary History, Vol. 8, No. I, Readers and Spectators: Some Views and Reviews (Autumn, 1976), pp. 15-4I.

ALPERS, Svetlana. The Art of Describing: Dutch Art in the Seventeenth Century. Cambridge: Cambridge University Press, 1983.

BROWN, Jonathan. "Sobre el Significado de Las Meninas", em Otras Meninas, ed. Fernando Marías. Madrid: Siruela, 1995

CHASTEL, André. "La Figure dans l'encadrement de la porte chez Velázquez", em Fables, Formes, Figures II. Paris: Flammarion, 1978

DAMISCH, Hubert. L'Origine de la Perspective, Flammarion, Paris, 1987

EMMENS, J. A. "Las Meninas de Velázquez: Espejo de Príncipes para Felipe IV", em Otras Meninas, Fernando Marías (org.). Madrid: Ediciones Siruela, 2007, p. 63.

FOUCAULT, Michel. As Palavras e as Coisas. Uma arqueologia das ciências humanas, 8a ed., trad. Salma Tannus Muchail. São Paulo: Martins Fontes, 1999.

KNOWLSON, R. "The idea of gesture as a Universal Language in the XVIIth and XVIIIth Centuries", Journal of the History of Ideas, p. 26.

MARÍAS, Fernando (org.). Otras Meninas. Madrid: Ediciones Siruela, 2007. 
MCKIM-SMITH, Gridley; FIEDLER, Inge; MACBETH, Rhona; NEWMAN, Richard; ZUCCARI, Frank. "Velázquez: Painting from Life", Metropolitan Museum Journal, Vol. 40, Essays in Memory of John M. Brealey (2005), pp. 79-9I.

PALOMINO, Antonio. Velázquez: Biografías de los Siglos XVII y XVIII. Homenaje en el Tercer Centenario de su muerte. Madri: Instituto Diego Velázquez, 1960, p. 70.

SEARLE, John R., "Las Meninas and the Paradoxes of Pictorial Representation", Critical Inquiry, 6, no. 3 (1980), pp. 477-488

STEINBERG, Leo. "Velázque's Las Meninas", October, I9 (I98I), pps. 45-55

SYNDER, Joel; COHEN, Ted. "Critical Response. Reflexions on Las Meninas: Paradox Lost, Critical Inquiry, 7, no. 2, (1980), pps. 539-572

STRATTON-PRUITT (ed.). Suzanne. Velázquez's Las Meninas, Cambridge: Cambridge University Press, 2003.
Sobre a representação da mulher

e feminismo na história da arte

ARMSTRONG, Carol. Manet, Manette. New Haven and London, 2002.

ARMSTRONG, Carol. Odd Man Out: Readings of the work and reputation of Edgar Degas.

Chicago: Chicago University Press, 1994.

BERHEIMER, Charles. Figures of Ill Repute:

Representing Prostitution in Nineteenth-Century France. Durhan: Duke University Press, 1997.

BERNHEIMER, Charles. "Degas's Brothels: Voyeurism and Ideology", in Representations, No. 20, Special Issue: Misogyny, Misandry, and Misanthropy (Autumn, 1987), pp. I58-I86.

BROUDE, Norma. Impressionism. A Feminist Reading: the Gendering of Art, Science and Nature in Nineteenth Century. New York: Rizolli, I99I.

BRYSON, Norman. Tradition and Desire: From David to Delacroix. Cambridge: Cambridge University Press, 1984.

BRENAN, Teresa; JAY, Martin (orgs.). Vision in Context: Historical and Contemporary Perspectives of Sight,. Nova Iorque: Woutledhge, I996.

CRARY, Jonathan. Técnicas do Observador: Visão e Modernidade no Século XIX. São Paulo, Contraponto, 2015

CLAYSON, Hollis. Painted Love, Prostitution in France Impressionist Era. New Haven: Yale University Press, 2004. 
CORBIN, Alain. "Commercial Sexuality in Nineteenth Century France: a system of images and regulations". In: The Making of the Modern Body: Sexuality and Society in Nineteenth-Century, ed. Catherine Callager, Brekeley: University of California Press, 1987.

CORBIN, Alain. "Hérédoshyphilis ou l'impossible redemption. Contribuition à l'histoire de l'herediré morbide". In: Romantisme, I98I, nº 3I, pp. I3I-I5O.

DUNCAN, Carol. "The MOMA's Hot Mamas". In Art Journal, Vol. 48, No. 2, Images of Rule: Issues of Interpretation (Summer, 1989), pp. I7 I-I78

DUNCAN, Carol. "Virility and Domination in Early 2oth Century Art”. In: Artforum, Dezembro 1973, pp. 30-39.

GARB, Tamar. Women impressionists. Oxford: Phaidon, I986.

GARB, Tamar. Bodies of Modernity: Figure and Flesh in Fin de Siècle France. Londres: Thames and Hudson, 1998.

GALLAGHER, Catherine; LAQUEUR, Thomas. The Making of the Modern Body: Sexuality and Society in the Nineteenth Century. Berkeley: University of California Press. I897

FOSTER, Hal (org). Vision and Visuality. Washington: Dia Art Foundation, 1988.

LAQUEUR, Thomas. Making sex: Body and Gender From the Greeks to Freud. Cambrigde: Harvard University Press, 1992.

LIPTON, Eunice. Looking into Degas: Uneasy Images of Women and Modern Life, Berkeley, Los Angeles, and London: University of California Press, 1986.
MULVEY, Laura. "O prazer visual e o cinema narrativo", em A Experiência do Cinema, Ismail Xavier (org.), São Paulo: Paz e Terra, I986, pp. 437-456.

NOCHLIN, Linda. Body in Pieces: Fragment as metaphor of Modernity. Thames and Hudson: 200I.

NOCHLIN, Linda. Impressionist Portraits and the Construction of Modern Identity, in Renoir portraits: Impressions of an Age. New Haven and London: Yale University Press, 1997

NOCHLIN, Linda. Death and Gender in Manet's Still Lifes. In Art in America, 20.

NOCHLIN, Linda. Representing Women. London: Thames and Hudson, 1999

POLLOCK, Griselda; PARKER, Rosita. Old Mistresses. Women, Art and Ideology. Londres: Rivers University Press, I98I.

POLLOCK, Griselda. Vision and Difference. Femininity, Feminism and History of Art. Londres: Routlegde, I988. 
Sobre Marcel Duchamp e Étant Donnés

CABANNE, Pierre. Marcel Duchamp, o Engenheiro do Tempo Perdido. São Paulo: Ed. Perspectiva, 2012.

CLAIR, Jean. Sur Marcel Duchamp et la Fin de l'Art. Paris: Gallimard, 2000.

DAUBNER, Ernestine. "Etant donnés: Rrose/ Duchamp in a Mirror." ACAR: revue d'art canadienne / Canadian Art Review, Vol. 22, No. I/2 (1995), pp. 87-96.

DE DUVE, Thierry (ed.). The Definitely Unfinished Marcel Duchamp, Halifax: Nova Scotia College of Art and Design, I99I.

DECIMO, Marc (org.). Marcel Duchamp et l'Érotisme, Dijon: Les Presses du Réel, 2008.

DUCHAMP, Marcel. Manual of Instructions: Étant Donnés. New Haven: Yale University Press, 2009.

FORGE, Andrew. "The Silence of Marcel Duchamp", Listener, 5 de Novembro de 1959, pp. 775-6.

GRAY, Cleve. "The great espectator", Art in America, vol. 57, no. 4, julio-agosto de 1969, Nova York.

HALADYN, Julian Jason. Marcel Duchamp Étant Donnés, Londres: Afterall Books e University of the Arts London, 2010.

JONES, Amelia. Postmodernism and the En-gendering of Marcel Duchamp, Cambridge: Cambrigde University Press, 1994.

JOUFFROY, Alain. "Étant Donné Marcel Duchamp: I) Individualiste Revolutionnaire, 2) Respirateur". In: Opus International, no. 49, Março de 1974.
KRAUSS, Rosalind. "Capítulo V". In: The Optical Uncounciouss, Massachussets: MIT Press, I993, pp. 95-I4.

LYOTARD, Jean-François. "Étant donnés, le dernier nu", in: Marcel Duchamp, abécédaire, org. Jean Clair, Paris: Museé National d'Art Moderne et Centre National d'Art et de Culture Georges Pompidou, I977.

MASHEK, Joseph. Duchamp in Perspective. Englewood Cliffs, N.J., Prentice Hall, 1975.

MOIRA e ROTH, William, "John Cage on Marcel Duchamp". In: Art in America (November-December 1973).

PAZ, Octavio. Michel Duchamp ou o Castelo da Pureza. São Paulo: Ed. Perspectiva, 1977.

SEIGEL, Jerrold. The Private Worlds of Marcel Duchamp, Berkeley e California: University of California Press, 1997.

TOMKINS, Calvin. Duchamp, uma biografia, trad. Maria Thereza de Rezende Costa. São Paulo, Cosac Naify, 2004

WITHAM, Larry. Picasso and the Chessplayer: Picasso, Duchamp and the Battle for the Soul of Modern Art. Hannover e Londres: New England University Press, 2013. 
Outras referências bibliográficas

ALBERTI, León Batisti [I435]. Da Pintura, $2 a$. Ed., Campinas: Ed. Unicamp, 1999.

ARASSE, Daniel. L'Annonciation Italienne: une histoire de perspective. Paris, Éditions Hazan, 2010.

AUMONT, Jacques. "Le plan", in BAECQUE, Antoine de (org.), Cahiers du cinéma - Le siècle du cinéma, Hors- série, novembro de 2000 , p. 38 .

BAUDELAIRE, Charles. Escritos sobre Arte, trad. Plínio Augusto Coelho. São Pauloo: Hedra, I998

BELTING, Hans. "A janela e o muxarabi: uma história do olhar entre Oriente e Ocidente”. In: Pensar a Imagem, Emmanuel Alloa (org.), Belo Horizonte: Autêntica Editorial, 2015

BENJAMIN, Roger. Recovering authors: the modern copy, copy exhibitions and Matisse. (Art History, vol. I2 no. 2, junho de I989, pp. I77-2OI.

BONITZER, Pascal. "Le suspense hitchcockien", in Le champ aveugle: essais sur le cinéma, Paris: Gallimard; Cahiers du cinéma, I982, p. 6I.

BURCH, Noel. Práxis do Cinema, trad. Marcelle Pithon e Regina Machado. São Paulo: Ed. Perspectiva, I992, pp. 2 I-53.

BRYSON, Norman. Looking at the Overlooked: Four essays on Still-life Painting. Londres: Reaktion Books, I990, p. I5O.

CHARBONNIER, Louise. Cadre et Regard: Généalogie d'un dispositive, Paris: l'Harmattan, 2007.
CHASTEL, André. Arte et Humanismeà Florence au temps de Laurent le Magnifique. Paris: P.U.F., I982.

CHIPP, H. B. Teorias da Arte Moderna. São

Paulo: Martins Fontes, 1999

COURTINE, Jeans-Jacques e HAROCHE, Claudine. História do Rosto: Exprimir e calar as emoções.

DIDI-HUBERMANN, George. Invention of Hysteria: Charcot and the Photographic Iconography of the Salpêtrière. Cambridge: MIT Press, 2004.

DAMISCH, Hubert. Judgement of Paris. Chicago: University of Chicago Press, 1996.

FOUCAULT, Michel. Vigiar e Punir: nascimento da prisão; tradução de Raquel Ramalhete.

Petrópolis: Vozes, 1987

FOUCAULT, Michel. História da Sexualidade I: A vontade do Saber; tradução Maria Thereza da Costa Albuquerque e J. A. Guilhon Albuquerque. Rio de Janeiro: Edições Graal, 1988.

FOUCAULT, Michel. História da Sexualidade II: O uso dos Prazeres; trad. Maria Thereza da Costa Albuquerque e J. A. Guilhon Albuquerque. Rio de Janeiro: EdiçõesGraal, I988.

FREIRE COSTA, Jurandir. Vestígio e a Aura: corpo e consumismo na moral do espetáculo. Rio de Janeiro: Garamond Universitária, 2004.

FREUD, Sigmund. Interpretação dos Sonhos; trad. Renato Zwick. Porto Alegre: L\&PM, 2012.

GRAFTON, Anthony. "Historia and Istoria: Alberti's Terminology in Context", in I Tatti Studies in the Italian Renaissance, Vol. 8 (I999), pp. 37-68. 
GREENBERG, Clement. Arte e Cultura:

Ensaios Críticos, São Paulo: Cosac Naify, 2013

GOMBRICH, E. H. The Image and The Eye. Londres: Phaidon, 1986.

HAVERKRAMP BEGEMANN, Egbert e LOGAN, Carolyn. Creative Copies: Interpretative Drawings from Michelangelo to Picasso. Nova Iorque: The Drawing Center, 1988

JAY, Martin. Downcast Eyes: The Denigration of Vision in Twentieth-Century French Thought. Berkeley e Los Angeles: University of California Press, I994.

KRAUSS, Rosalind. Willen de Kooning Non Stop: Cherchez la femme. Chicago e Londres: University of Chicago Press, 2015

KRAUSS, Rosalind, "Originality as Repetition: Introduction”, October vol. 37, I986, pps. 35-40.

KRISTEVA, Julia. "A palavra, o diálogo e o romance”, em Introdução à semanálise. Trad. Lúcia Helena França Ferraz, $2^{\text {a }}$. ed., São Paulo: Perspectiva, 2005.

LACAN, Jacques. Os quarto conceitos fundamentais da psicanálise. Rio de Janeiro: Jorge Zahar Editor, 2005.

LACAN, J. “O estádio do espelho como formador da função do eu tal como nos revela a experiência psicanalítica". In LACAN, J. Escritos, pp. 96 - IO3. Rio de Janeiro: Jorge Zahar Editor, I998.

LACAN, J. A angústia. Jorge Zahar Ed., Rio de Janeiro, 2005.

LAFUENTE FERRARI, Enrique. Breve Historia de la Pintura Española, Madri: Editorial Tecnos, 1946.
MAISON, K. E. Themes and Variations: Five Centuries of Master Copies and Interpretations. Londres e Nova Iorque: Harry N. Abrams, 1960.

MARTINEZ, Adolfo Carrasco. "Fisionomia de la virtud: Gestos, movimientos y palabras en la cultura cortesano-artistocrática del siglo XVII", Reales Sítios, 37, no. I 47 (200I), pps. 26-37.

MARIN, Louis. Détruire la Peinture. Paris: Galilée 1977 .

OLIVEIRA JR., Luiz Carlos. Vertigo, a teoria artística de Alfred Hitchcock e seus desdobramentos no cinema moderno. Tese (Doutorado em Meios e Processos Audiovisuais) - Escola de Comunicações e Artes, Universidade de São Paulo, , São Paulo.

PANOFSKY, Erwin. A perspectiva como forma simbólica, trad. Elisabete Nunes. São Paulo: Edições 70, 1993.

PEREZ-ORAMAS, Luiz. "El perro y el pie. Nota sobre lo inconcluso”, em Dietario, El Nacional, 7 de abril de 20 I9.

REFF, Theodore, Manet: Olympia. Londres: Penguin, 1968, p. 98.

RESTANY, Pierre. Os Novos Realistas, trad. Mary Amazonas Leite de Barros, São Paulo: Ed. Perspectiva, 1979.

SARTRE, Jean-Paul. O Ser e o Nada: Ensaio de Ontologia Fenomenológica, trad. Paulo Perdigão. Petrópolis: Editora Vozes, 1997

SALZSTEIN, Sônia (org.) Matisse: Imaginação, Vida e Erotismo. São Paulo, Cosac Naify, 2009

SCHIFF,Richard. "Representation, Copying and the Technique of Originality". In: New Literary History, vol I5, no. 2, I984, pp. 333-63. 
SPENCER, John R. "The Spatial Imagery of Annunciation in Feeftenth Century Florence". In: The Art Bulletin, Vol. 37, No. 4 (Dec., I955), pp. 273-280.

STOICHITA, Victor. Breve História da Sombra. Lisboa: KKYM, 1997.

STOICHITA, Victor. L'Instauration du Tableau. Paris: Librerie Droz, 1999.

STOICHITA, Victor. L'Effet Sherlock Holmes. Variations du regard de Manet a Hitchcock. Paris: Hazan, 2015.

SYMMONS, Sarah. "John Flaxman and Francisco Goya: Infernos Transcribed". In: The Burlington Magazine, Vol. II 3, No. 822 (Sep., I97I), pp. 506-5I2.

VON HOR SKAFF, Susan. "The Virgin Annunciate in Italian Art of the Late Middle Ages and Renaissance", in College Literature, Vol. 29, No. 3, Literature and the Visual Arts (Summer, 2002), pp. I09-I23.

XAVIER, Ismail. O discurso cinematográfico: a opacidade e a transparência, $3^{\text {a }}$ edição. São Paulo, Paz e Terra, 2005 


\section{Créditos da imagens}

\section{CRÉDITOS DAS FOTOS}

(C) Museu Picasso, Barcelona. Fotografía, Gasull Fotografia., figs. 2-10, 15, 16, 20-22, 27-30, 32-33, 37-45, 47, 48, 51, 56-59, 60, 62, 64, 69, 70-72.

Steve Legato, para o New York Times, fig. 67.

\section{CRÉDITOS DOS ARTISTAS}

(C) Sucession Picasso/DACS, 2019, figs. 2-10, 15, 16, 20-22, 27-30, 32-33, 37-45, 47, 48, $51,56-59,60,62,64,69,70-72$.

Todas as quarenta e oito pinturas da série Las Meninas foram doações de Pablo Picasso ao Museu Picasso Barcelona em 1968, e são catalogadas sob os registros MPB 70. 433 - MPB 70. 490. Além disso, as fig. 34 e 69 compõem o mesmo acervo e são catalogada sob os regitros MPB 110. 213 e MPB 70. 433, respectivamente. A primeira delas foi adquirida por doação de Pablo Picasso em 1970 e a última foi doação de Catherine Hutin ao museu em 2009.

As imagens 71a, 71b e 75 foram retiradas, respectivamente de: DAMISCH, Hubert. L'Origine de la Perspective, Flammarion, Paris, 1987, p. 379 • SYNDER, Joel; COHEN, Ted. "Critical Response. Reflexions on Las Meninas: Paradox Lost, Critical Inquiry, 7, no. 2, (1980), p. 435 • LYOTARD, Jean-François. "Étant donnés, le dernier nu", in: Marcel Duchamp, abécédaire, org. Jean Clair, Paris: Museé National d'Art Moderne et Centre National d'Art et de Culture Georges Pompidou, 1977, p. 88. 
